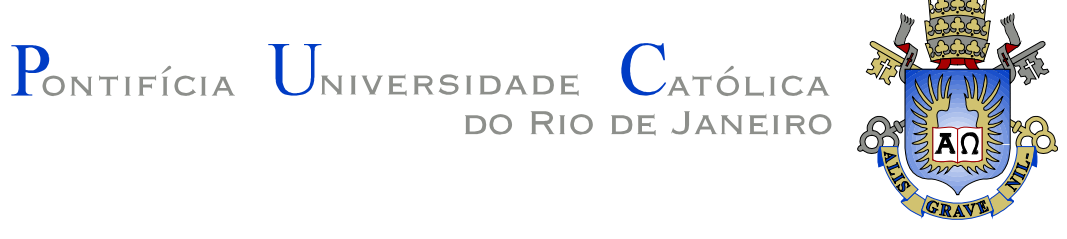

Juliana Fausto de Souza Coutinho

\title{
A cosmopolítica dos animais
}

Tese de doutorado

Tese apresentada como requisito parcial para obtenção do grau de Doutor pelo programa de Pós-Graduação em Filosofia do Departamento de Filosofia da PUCRio.

Orientadora: Profa ${ }^{a}$. Déborah Danowski 


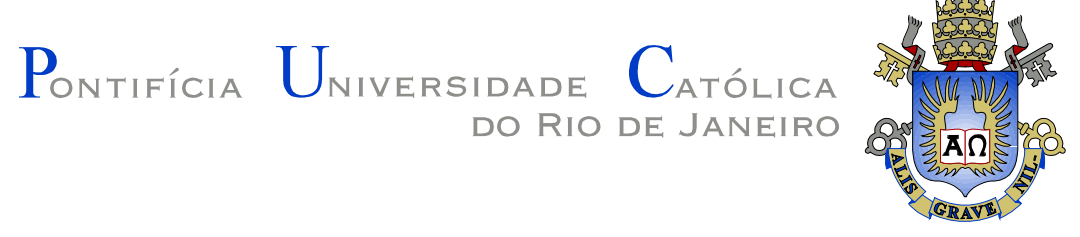

\title{
Juliana Fausto de Souza Coutinho
}

\section{A cosmopolítica dos animais}

Tese apresentada como requisito parcial para obtenção do grau de Doutor pelo Programa de Pós-Graduação em Filosofia do Departamento de Filosofia do Centro de Teologia e Ciências Humanas da PUC-Rio. Aprovada pela Comissão Examinadora abaixo assinada.

\author{
Prof ${ }^{a}$ Déborah Danowski \\ Orientadora \\ Departamento de Filosofia - PUC-Rio \\ Prof. Felipe Sussekind Viveiros de Castro \\ Departamento de Ciências Sociais - PUC-Rio \\ Prof. Peter Pál Pelbart \\ Pontifícia Universidade Católica de São Paulo-PUC/SP \\ Prof. Eduardo Batalha Viveiros de Castro \\ Universidade Federal do Rio de Janeiro - UFRJ \\ Profá. Rita Leal Paixão \\ Universidade Federal Fluminense - UFF \\ Profa. Monah Winograd \\ Coordenadora Setorial de Pós-Graduação e Pesquisa do Centro \\ de Teologia e Ciências Humanas - PUC-Rio
}

Rio de Janeiro, 19 de setembro de 2017. 
Todos os direitos reservados. É proibida a reprodução total ou parcial do trabalho sem a autorização da universidade, da autora e da orientadora.

\section{Juliana Fausto de Souza Coutinho}

Graduou-se em Filosofia na Universidade Federal do Rio de Janeiro (UFRJ) em 2001 e fez Mestrado em Letras na Pontifícia Universidade Católica do Rio de Janeiro (PUC-Rio) em 2012.

Ficha Catalográfica

Coutinho, Juliana Fausto de Souza

A cosmopolítica dos animais / Juliana Fausto de Souza Coutinho ; orientadora:

Déborah Danowski. - 2017.

300 f. ; $30 \mathrm{~cm}$

Tese (doutorado) - Pontifícia

Universidade Católica do Rio de Janeiro, Departamento de Filosofia, 2017.

Inclui bibliografia

1. Filosofia - Teses. 2. Cosmopolítica.

3. Relações multiespecíficas. 4. Animais. I. Danowski, Déborah. II. Pontifícia Universidade Católica do Rio de Janeiro. Departamento de Filosofia. III. Título.

CDD: 100 
Aos meus companheiros Marco Antonio, Bruxo, Nausicaa e Batatinha, que me inventam diariamente e me tornam capaz. 


\section{Agradecimentos}

À PUC-Rio, ao CNPq e à FAPERJ, pelo auxílio concedido.

À Déborah, melhor orientadora do mundo e amiga do coração.

Aos amigos e familiares que pacientemente me apoiaram e estimularam: Shirley, Júlio, Nancy, Rapha, Yara, Ismar, Rondinelly, Isabela, Ceci, Alyne, Eduardo, Andressa, Alexandre, Flávia, Marcos, Orlando e a moçada do Corações Vulgares.

Às mulheres que me ensinam a pensar e ver o mundo diferentemente: Donna Haraway, Vinciane Despret, Val Plumwood, Deborah Bird Rose, Isabelle Stengers, Ursula K. Le Guin, Virginia Woolf e Déborah Danowski.

À Carla Forte Maiolino Molento, à Vanessa Bones e a todos os pesquisadores do LABEA - Laboratório de Bem-Estar Animal da UFPR, pela generosidade com que me receberam e pelo exemplo de dedicação rigorosa e amorosa aos animais.

Aos membros da banca, Eduardo Viveiros de Castro, Felipe Sussekind, Peter Pál Pelbart e Rita Paixão, por considerarem este trabalho.

$\grave{A}$ internet e todos aqueles comprometidos com o compartilhamento de fontes e ideias.

Aos animais com quem vivi e com os quais me constituí: Bú, Milady, Leonel, Lady, Eleonora, Anabel, Michkin, Aliocha, Pingo, Bernadete, Nausicaa, Bruxo e Batatinha; aos que conheci pessoalmente ou por leituras; aos que comi; a todos aqueles que, mesmo em situações inimagináveis, lutam diariamente para fazer e manter seus mundos, por me mostrarem o que significam fé e força.

Ao Marco Antonio: mil anos!

God only knows what I'd be without you 


\section{Resumo}

Coutinho, Juliana Fausto de Souza; Danowski, Déborah. A cosmopolítica dos animais. Rio de Janeiro, 2017. 300 p. Tese de doutorado. Departamento de Filosofia, Pontifícia Universidade Católica do Rio de Janeiro.

Esta tese tem por objetivo investigar, desde um ponto de vista filosófico, a vida política dos animais outros que humanos no contexto do Antropoceno. Entre diversas configurações, a errância, o confinamento, a experimentação e a extinção são privilegiadas como verdadeiras situações conceituais, cuja análise e problematização requerem a abordagem conjunta da filosofia com diferentes discursos, como a etologia, a biologia, a antropologia, a história e a literatura. $\mathrm{O}$ primeiro passo consiste em uma exploração do lugar nos animais na pólis a partir da confrontação de ideias clássicas e contemporâneas sobre política; em seguida passa-se a uma análise do zoológico tomado como modelo da política humana, oferecendo-se, como alternativa, feições possíveis de uma política animal a partir dos diversos sentidos do conceito de brincadeira; o terceiro momento examina experimentações multiespecíficas no âmbito das artes, com foco na literatura, e no de práticas científicas, observando seus diferentes modos de mundificação; finalmente, procede-se à elaboração de uma noção de extinção não tanto como um fato, mas como acontecimento, diante do qual o cultivo imaginativo de narrativas de luto e as experiências de continuidade são necessários. Por este percurso, conclui-se que, ainda que acossados por todos os lados, os animais outros que humanos vivem e oferecem possibilidades cosmopolíticas diante das quais a humanidade compreendida como exceção ontológica se evidencia como potência apolítica.

\section{Palavras-chave}

Cosmopolítica; relações multiespecíficas; animais 


\section{Abstract}

Coutinho, Juliana Fausto de Souza; Danowski, Déborah (Advisor). The Cosmopolitics of Animals. Rio de Janeiro, 2017. 300 p. Tese de doutorado. Departamento de Filosofia, Pontifícia Universidade Católica do Rio de Janeiro.

The present thesis aims to investigate, from a philosophical standpoint, the political life of other-than-human animals in the context of the Anthropocene. Amid several configurations, errancy, confinement, experimentation and extinction are privileged as actual conceptual situations, the analysis and problematization of which require a combined approach between philosophy and other discourses, such as ethology, biology, anthropology, history and literature. The first step consists of an exploration of the animal's place in the polis taking as a starting point a confrontation between classic and contemporary ideas regarding politics; following that, an analysis of the zoo viewed as a model of human politics, to which are offered, as alternatives, possible features of an animal politics taking as a starting point the several meanings of the concept of play; the third section examines multispecies experiments in the realm of the arts, especially literature, and in the realm of scientific practices, noting different modes of worlding respective to each; lastly, we proceed to the elaboration of a notion of extinction, not so much as a fact but as a event in the face of which the imaginative cultivation of grief narratives and experiences of continuity is necessary. So reasoning, we conclude that, although accosted on all sides, otherthan-human animals live and offer cosmopolitical possibilities in the face of which humanity, understood as ontological exception, proves itself to be an apolitical power.

\section{Keywords}

Cosmopolitics; multispecies relations; animals 


\section{Sumário}

1 Introdução 11

2 Errantes 18

2.1. Pet Sounds 18

2.2. A velha dos gatos 23

2.3. "Expulsos do espaço urbano" 29

2.4. Indistinção e indiscernibilidade 36

2.5. Amizade e pastoreio 44

2.6. Razão do mestre versus saberes situados 51

2.7. Guerras felinas 62

2.8. Habitar o problema 72

2.9. Fim de uma colônia 79

3 Confinados 83

3.1. De Monkey Islands e paradoxos 83

3.2. Soberania e patologia 93

3.3. "Algo que foi tornado absolutamente marginal" 98

3.4. "Tristes filósofos" 102

3.5. "Aberrificação" 109

3.6. "Donzellas... para pentear macaco" 115

3.7. E, ainda assim, brincaram 120

3.7.1. "Fair play" 121

3.7.2. "Proliferação louca de formas" 132

3.8. Política animal 141

4 Experimentais $\quad 148$

4.1. Arte 148

4.1.1. Rotpeter e Consul 148

4.1.2. Literatura e povo 156 
4.1.3. Devir-animal 163

$\begin{array}{ll}\text { 4.1.4. Cosmoliteratura } & 171\end{array}$

4.1.5. "Think my way into the existence of a being" 176

4.1.6. Sultão 184

4.2. Ciência 189

4.2.1. Cabeça (de homem) 189

4.2.2. Bestial com as bestas 195

4.2.3. Cauda (de rato) 202

4.2.4. Kluger Hans 208

$\begin{array}{ll}\text { 4.2.5. Parentesco como política } & 217\end{array}$

5 Desaparecidos $\quad 221$

5.1. Fins do mundo 221

5.1.1. Homens 222

5.1.2. Ratos 229

5.2. Casa mal-assombrada 236

5.3. Zumbis 239

5.4. Histórias de vivos e de fantasmas 246

5.5. Sangue e vísceras 256

6 Conclusão 261

7 Referências bibliográficas $\quad 279$ 
God in the Bible says, "Let there be light." Only we humans, according to that bible, are in God's image. So only God and We can say "Let there be light."

But I ask you, what is a rooster at four in the morning saying?

Ursula K. Le Guin, "Cheek by Jowl. Animals in Children Literature"

Over and over the crow cries uncover the cornfield.

Van Dyke Parks, "Cabinessence" 


\section{Introdução}

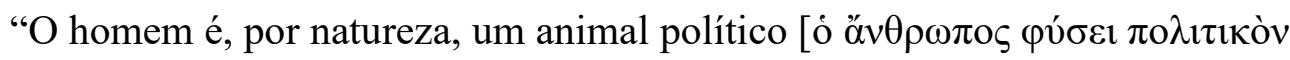

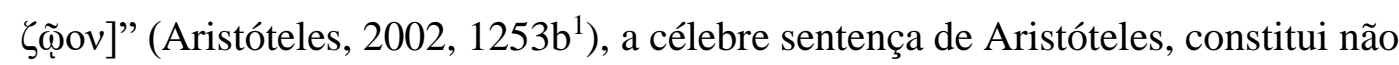
apenas um dos fundamentos de sua teoria política, mas um dos pilares desse pensamento no Ocidente. Houve, e há, defensores e detratores da ideia, mas ela tem sido, senão inescapável, profundamente influente, adentrando mesmo a cultura popular, o que não acontece frequentemente com discursos filosóficos. Os quatro termos da frase remetem a conceitos complexos que suscitam constante disputa quanto a seu significado: homem, natureza, animal e política. Além disso, eles são conjugados de um modo que encerra muitas questões que foram e continuam sendo matéria de debate - o homem é ou não um animal, possui ou não uma natureza, é determinado por ela ou a determina, a política é ou não natural e o que quer dizer natureza ou natural nesses contextos, entre outras. Por entre esses e outros problemas que se entrelaçam com eles, tais como os de justiça, lei, direitos, propriedade e formas de governo, o que se chama de filosofia política parece ter se fixado exclusivamente no homem.

"Que o homem é um animal político em maior medida que todas as abelhas e todos os animais de bando (idem) é claro", continuava o filósofo grego. É que, para ele, só o homem possuiria lógos - discurso, razão, linguagem -, o mais fundamental dos muitos avatares da distinção humana que o pensamento ocidental produziu em sua história. Os animais, sempre os outros diante dos quais a humanidade se eleva singularmente, além de desprovidos de linguagem, razão, alma, ferramentas e incontáveis outras propriedades, restaram sem política. Homo homini lupus, a máxima evocada por Thomas Hobbes na Epístola Dedicatória de seu De Cive, aponta para a condição bruta e bestial das cidades em sua relação entre si, isto é, sem um Estado dos Estados que as ordene. Sem essa autoridade superior, ali onde não se encontra um mestre, retorna-se ao estado de natureza,

\footnotetext{
${ }^{1}$ As traduções dos textos citados, quando não houver menção ao tradutor nas Referências Bibliográficas, são de minha autoria.
} 
aquele dos lobos considerados canibais, configuração sumamente a-política. No debate político, os animais surgem apenas como metáforas, símbolos - lobos, leões, ratos, cobras e cordeiros sendo algumas delas - que significam certas disposições ou ânimos sem no entanto se referirem aos bichos e suas populações.

Atualmente, o campo conhecido como estudos animais, que reverbera um interesse renovado por esses outros viventes que dividem o planeta com a humanidade, tendo se tentacularizado em disciplinas como filosofia, literatura, antropologia, história e outras, também começa a delinear uma teoria política animal. Volumes como Zoopolis (2013), de autoria dos filósofos Will Kymicka e Sue Donaldson, ou Political Animals and Animal Politics (2014), editado pelos teóricos da política David Schlosberg e Marcel Wissenburg, procuram tornar políticas questões de direito ou ética animal por meio de sua institucionalização. O primeiro livro elabora categorias possíveis para animais de diversos tipos (cidadania para animais domésticos; soberania de território para selvagens; residência ou cidadania naturalizada [denizenship] para sinantrópicos ou liminares), de modo que se possa, segundo seus autores, travar relações realmente políticas com eles (cf. Kymlicka e Donaldson, 2013). O segundo propõe que sair da ética para a prática política requereria "a imposição oficial de regras legítimas e legimitizadas, incluindo sanções, no todo da sociedade política" (Schlosberg e Wissenburg, 2014, p. 1). Em um artigo de 2015, dois teóricos da política, Svenja Ahlhaus e Peter Niesen, procuraram resumir as características da área de política animal:

[Ela] diz respeito à sujeição política de humanos e animais [...] e à existência, natureza e justificativa das reivindicações coercivas dos animais [...]. Discute a inclusão dos animais nas políticas humanas e as reivindicações de coletivos animais 'soberanos' [...]. A política animal desenvolve diretrizes normativas com vistas à sua realização prática [...] e, finalmente, reflete sobre seu próprio status como um corpo de discurso dentro de sociedades democráticas (Ahlhaus e Niesen, 2015, p. 10).

O caminho seguido por esta tese afasta-se dessa abordagem por não acreditar que política indique apenas o âmbito das instituições políticas nas formas Estado. Pelo contrário, o que se pretende com os capítulos a seguir é procurar definições de política ou práticas políticas que envolvam os animais criativamente, configurações políticas possíveis que sejam co-constituídas com os animais. Não se deseja, com isso, abandonar o campo prático de ação, mas 
investir nele em alianças cuja proeminência não seja aquela de instituições humanas que, ademais, foram construídas por exclusão dos animais. Tampouco se busca a reunião ou produção de normas e diretrizes, pois os caminhos são tão múltiplos quanto o são os modos de coabitar o mundo pelas incontáveis populações animais. Não se trata, portanto, de um trabalho sobre ética ou sobre uma teoria política animal advinda desta, mas de um trabalho que pretende fazer deslocar o sentido do que se chama política. Em suma, o objetivo desta tese é traçar linhas e caminhos que devolvam a política ao mundo e seus seres.

Interessam-me sobretudo a situação dos animais outros que humanos, bem como as políticas concretas, possíveis e experimentais que os capturam, ativam, oprimem ou são compostas com eles. Seja pela perda de habitat e modos de vida, seja por sua categorização como animais de companhia, pestes, escravos, cobaias ou trabalhadores, nos imensos campos em que se os mantêm confinados, pela reprodução forçada, pela morte impedida e pelo extermínio, os animais estão implicados e são atores numerosos e potentes nas histórias e estórias que tecemos hoje, no começo do século XXI, sob o signo do capitalismo liberal, na época geológica chamada Antropoceno. É diante deles e com eles que procuro construir esta tese. Para tanto, procuro responder à exortação de Val Plumwood de que devemos ser capazes de "pensar diferentemente", talvez a única saída possível face à destruição atual: "Esqueçam o modelo da máquina passiva e nos contem mais sobre as capacidades auto-inventivas e auto-elaborativas da natureza, sobre a intencionalidade do mundo não-humano" (Plumwood, 2009, s/p). Se a "mansão das liberdades modernas repousa sobre uma base de uso de combustíveis fósseis em permanente expansão" (Chakrabarty, 2013, p. 11) e, eu acrescentaria, sobre a opressão de uma infinidade de entes humanos e outros que humanos, e se esse movimento nos trouxe até um momento de perigo e devastação, é preciso começar a pensar de outro modo. Ou, antes, é preciso levar a sério a exortação de Virginia Woolf, retomada por Donna Haraway: "Think we must! We must think ${ }^{2}$ " (Haraway, 2016b, p. 36).

${ }^{2}$ Em Three Guineas, a escritora inglesa convocava as mulheres: "Pensar nós devemos. Vamos pensar nos escritórios; nos ônibus; enquanto estamos plantadas na multidão assistindo a Coroações e aos shows do Prefeito; vamos pensar enquanto passamos pelo Cenotáfio; e em Whitehall; na galeria da Câmara dos Comuns; nos Tribunais de Justiça; vamos pensar nos batismos, casamentos e funerais. Vamos nunca cessar de pensar - o que é esta 'civilização' na qual nos encontramos? O que são essas cerimônias e por que deveríamos tomar parte nelas? O que são 
Hannah Arendt, que inspira Donna Haraway em seu estímulo ao pensamento - e à falta de pensamento [thoughtlessness] que leva até a banalidade do mal -, escreveu, nas Lectures on Kant's Political Philosophy, que "pensar com a mentalidade alargada significa treinar a própria imaginação a sair em visita [ $g o$ visiting]" (Arendt, 1992, p. 43). Retiro propositalmente sua frase do contexto original, profundamente ligado ao cosmopolitismo kantiano etno e antropocêntrico, e a recoloco no quadro do último parágrafo de "Nature in the Active Voice", quando Plumwood conclama:

Libere sua mente e faça suas próprias contribuições ao projeto de interrupção do reducionismo e do mecanicismo. Ajude-nos a reimaginar o mundo em termos mais ricos que nos permitirão nos encontrar em diálogo com e limitados pelas necessidades de outras espécies, outros tipos de mentes. Não lhes direi como fazêlo. Há muitos modos de fazê-lo. Mas espero que os tenha convencido de que este não é um projeto diletante. A luta para pensar diferentemente, para refazer nossa cultura reducionista é um projeto básico de sobrevivência em nosso presente contexto. Espero que vocês se juntem a ele (Plumwood, 2009, s/p; grifo meu).

Não tenho nenhuma ilusão quanto ao que posso fazer neste trabalho, algo infinitamente mais modesto do que pedia Plumwood. Gostaria de pensar, entretanto, que o espírito destas páginas vem pelo menos tangenciar essa enorme tarefa. Para tanto, visito algumas situações conceituais e experimento modos de relação nos quais os animais outros que humanos tenham a oportunidade de, existindo politicamente, ajudar a pensar de modo diferente e a efetivamente cultivar em conjunto, para usar a expressão de Anna Tsing, "artes de viver em um mundo danificado." 3 Como princípio, procuro sempre me referir a questões situadas, com animais humanos e outros que humanos determinados, sejam eles povos, indivíduos ou personagens, seguindo a indicação de Haraway que, inspirada por Marilyn Strathern, afirma que

Importa quais histórias contamos para contar histórias; importa quais nós atam nós, quais pensamentos pensam pensamentos, quais descrições descrevem descrições, quais vínculos vinculam vínculos. Importa quais histórias fazem mundos, quais mundos fazem histórias (Haraway, 2016b, p. 12).

Pretendo, assim, escapar àquilo que Jacques Derrida, em $O$ animal que logo sou chamava de o filosofema, o discurso que toma os animais outros que humanos abstratamente, como uma imensa categoria de seres indistintos e que não se

essas profissões e por que deveríamos fazer dinheiro com elas? Para onde, em suma, ela está nos levando, a procissão dos filhos de homens educados?" (Woolf, 2006, p. 1843-1851).

3 "Arts of Living on a Damaged Planet" foi o nome de um evento organizado por Tsing em 2014. 
permite ser visto por eles, entrar em relação com eles. Pensar de modo diferente não pode supor a elaboração do animal como "um teorema, uma coisa vista mas que não vê" (Derrida, 2002, p. 33).

Para tanto, privilegiarei algumas configurações concretas da vida dos animais no Antropoceno, como sua existência em cidades nas feições de pets e errantes, o confinamento ao qual são submetidos em zoológicos, as experimentações nas quais são parceiros ou cobaias, nas artes e nas ciências, e a sua desaparição pelos processos acelerados de extinção. $\mathrm{O}$ método utilizado no exame dessas situações envolveu a abordagem conjunta da filosofia com diferentes discursos, como a etologia, a biologia, a antropologia, a história e a literatura, na convicção de que o estudo das políticas animais exige um esforço conceitual multidisciplinar.

O primeiro capítulo parte da exploração de uma situação pessoal, a minha experiência com os gatos que passaram a viver comigo, para questionar o lugar tradicionalmente conferido aos animais na pólis. Nele, ideias clássicas e contemporâneas sobre política, como as de Aristóteles, Platão e Giorgio Agamben, são debatidas quanto à sua disposição em relação ao estatuto dos animais nas cidades. O pensamento, por sua vez, de autoras feministas como Val Plumwood, Donna Haraway e Isabelle Stengers provê um arcabouço conceitual com o qual abordar questões políticas em contextos multiespecíficos. Por ter vivido no Rio de Janeiro e em Curitiba e acreditar que a minha história e a dos gatos com quem moro está marcada pela história dessas cidades, elas servirão de referência neste momento.

No segundo, passo a uma análise do zoológico tomado como modelo da política humana compreendida como patológica por seu caráter anti-vida e antidevir; ao recuperar, em uma breve história dessa instituição, seus fundamentos coloniais, pretendo articular os modos através dos quais animais humanos e outros que humanos foram enredados em zonas de indistinção. Neste capítulo, o conceito de brincadeira, nas diferentes acepções que ele adquire nos discursos de autores como Brian Massumi, Gregory Bateson e Marc Bekoff, vem informar as expressões de uma possível política animal.

O terceiro capítulo examina experimentações multiespecíficas no âmbito das artes, sobretudo a literatura, e no de práticas científicas, observando seus diferentes modos de mundificação. Para tanto, são convocados os conceitos de 
povo, fabulação e devir-animal deleuzo-guattarianos, além de alguns textos de escritores como Franz Kafka, J. M. Coetzee e Ursula K. Le Guin, que oferecem saídas aos animais capturados pelas políticas humanas. A análise do lugar das bestas-máquinas cartesianas em práticas científicas do século XVII na Europa funciona como pano de fundo para uma discussão acerca da Razão, que, como procurarei mostrar, pode ser compreendida como faculdade de exclusão e desconhecimento, em contraposição à qual práticas mundanas, científicas e artísticas, de interesse e disponibilidade, permitem a criação de alianças multiespecíficas em devir-com, formando mundos ricamente habitados.

Finalmente, no quarto capítulo, procedo a um exame da Sexta Grande Extinção, considerando o aniquilamento de incontáveis espécies no Antropoceno como um acontecimento diante do qual o cultivo imaginativo de narrativas de luto e as experiências de continuidade são necessários. A partir de alguns eventos que marcaram a construção da cidade de Brasília, discuto o papel da humanidade enquanto espécie no atual evento de extinção em massa, incluindo a possibilidade de seu desaparecimento, e aponto, por meio dos estudos de Vinciane Despret, Thom van Dooren e Deborah Bird Rose, para a importância de criação, conservação e abandono de histórias no seio da catástrofe como modos pelos quais mundos vêm a ser, prosseguem e se extinguem.

A conclusão retoma os conceitos e situações trabalhados ao longo dos capítulos para encetar um debate acerca do imaginário da guerra no contexto dos modos de resistência em que se emaranham animais e seus aliados no Antropoceno.

Tais situações e passos não se pretendem nem poderiam ser exaustivos, dada a profusão imaginativa da vida animal, capaz de inventar novos mundos e modos de habitá-los politicamente mesmo diante das opressões mais abjetas. Se pensar é mesmo um modo de visitar, ao tomar este princípio como método, acredito tê-lo feito com a companhia dos autores mencionados, além de outros de igual relevância; os visitados, por seu turno, não foram os animais em geral ou a animalidade enquanto categoria; eles têm nomes, como Bruxo, Batatinha, Nausicaa, Tibbles, Nikkie, Yeoren, Mama, Tushi, Luit, Consul, Sultão, Rotpeter, Kluger Hans, Mohammed, Zarif, Martha e George e fazem parte de povos tão diversos e múltiplos quanto o dos gatos, cães, bois e vacas, cotovias-da-ilhastephen, galinhas, fragatas, cavalos, gorilas, chimpanzés, macacos rhesus, 
macacos aranha, lobos, OncoRato ${ }^{\mathrm{TM}}$, camundongos, ratos-pretos e candangos, babuínos, pombos-passageiros, formigas, alalas e dingos. Convencida de que somente através de encontros multiespecíficos com outros situados é possível urdir políticas cósmicas e não exterministas, proponho um mergulho nos olhos de alguns animais outros que humanos, na esperança de que, de dentro das trevas anunciadas pelo Antropoceno, esta "festa universal da morte, $[\ldots]$ perniciosa febre que ao nosso redor inflama o céu desta noite chuvosa" (Mann, 1952, p. 741), uma centelha que divise caminhos enlameados formados por rastros de bichos possa porventura brilhar. 


\section{2 \\ Errantes}

\section{1.}

Pet Sounds

Algumas semanas antes do início das aulas do doutorado para o qual acabara de ser admitida na PUC-Rio, da janela de meu apartamento, no quinto andar de um condomínio composto por cinco ou seis prédios e uma vasta área verde, comecei a ver um filhote de gato preto vagando e miando só. Tocada por sua fragilidade, decidi descer para observar seu estado - alimentá-lo, conhecê-lo. O gatinho era muito desconfiado e, assim que me percebia, sumia por entre plantas. Se quisesse dar de comer a ele, precisava deixar o alimento e me afastar; em uma dessas ocasiões, cheguei a imitar um miado para ele. Ele respondeu, miando de volta. Dialogamos, eu sem saber o que dizia, até que, após alguns minutos, ele resolveu se aproximar da comida que eu levara. Mesmo assim, era impossível tocá-lo. Em conversa com um funcionário do condomínio, este me explicou que o filhote tinha uma mãe e que, toda vez que a gata saía para procurar comida, ele se afastava de onde ela o havia deixado e perambulava miando pela área do condomínio. Fiquei aliviada ao saber que ele não estava sozinho no mundo, tão pequeno que era. E a palavra correu: uma certa moradora gostava de gatos.

Não demorou muito até que meu interfone tocou, uma senhora domiciliada no prédio de trás do meu avisando que havia encontrado dois filhotes muito novos, sem mãe, perguntando se eu não queria ficar com eles. A conversa envolveu, como é usual nos assuntos envolvendo animais errantes, termos como resgatar e adotar (a palavra resgatar, aliás, faz um jogo duplo no que tange aos felinos, contendo nela o nome popular da espécie - os animais que se retiram das ruas são muitas vezes chamados de resgatos, resgatinhos). Eu, que nunca havia tido contato com outro morador do lugar até então, fui até a casa dela, e encontrei, em um quarto, saindo de uma caixa própria para o transporte de gatos, duas pequenas bolinhas de pelo. Mínimos, deviam ter cerca de 10 dias. Dois bebês- 
gato, um preto e outro rajadinho, desamparados, no meio de um quarto daquele apartamento. O preto não saía de cima do outro, procurando ou the dando calor. Trouxe os dois para casa, mas seu tamanho diminuto me causou receio - e se eles não sobrevivessem, se não fossem capazes sem a mãe? Corremos, eu e Marco Antonio, meu companheiro, para uma clínica veterinária 24 horas que encontramos pelo Google. Lá, descobrimos que eles estavam já com hipotermia e que o melhor era deixá-los internados pelo menos por uma noite, tomando soro. Seus membros, que pareciam gravetos, foram espetados com uma agulha e os deixamos aos cuidados de todo um aparato biotecnológico especializado, desenvolvido há um bocado de tempo em nosso mundo e que envolve pesquisadores, cobaias, tecnologias e materiais diversos, investimentos em estudo, mercado e desejos, todo um dispositivo que gira em torno do tratamento médico do que chamamos pets.

No dia seguinte, quando fui buscá-los e fazia frio, a veterinária que cuidava deles me disse que era melhor que ficassem mais tempo internados. Nesta época eu ainda não começara a receber a bolsa que o $\mathrm{CNPq}$ viria a me conceder em breve para realizar a pesquisa do curso de doutorado - e a diária de internação naquela clínica era cara. Perguntei, então, se não conseguiria tratá-los eu mesma, em casa, ao que me foi respondido que poderia tentar, mas seria tarefa difícil. Eles, o preto, um macho, e a rajadinha, uma fêmea, eram de fato muito novos; além disso, haviam ficado sem comida e expostos ao frio até que minha vizinha os encontrasse. Estavam debilitados e precisariam de um cuidado muito especial, total dedicação: uma bolsa de água quente debaixo dos cobertores onde ficariam não conseguiam caminhar por si ainda e, nesta idade, os gatos não são capazes de manter constante a temperatura corporal, sendo o corpo da mãe que lhes provê o calor necessário -, mamadeira de 2 em 2 horas e, além disso, que alguém lhes ajudasse a fazer suas necessidades. A urina deveria, ao fim de cada mamada, ser retirada por meio de um algodão ou gaze umedecidos em água morna e delicadamente friccionados sobre seus genitais, imitando um gesto da mãe, que, ao lamber e limpar os filhotes, estimula sua bexiga e provoca a saída da urina. Ainda, deveria, sempre que possível, massagear seus abdomes para incentivar o funcionamento do sistema digestivo: era muito importante que defecassem em menos de uma semana, sob risco de vida. 
Por mais de quinze dias não dormi uma noite inteira, completamente tomada pelas tarefas que a sobrevivência daqueles dois bichinhos me exigia. A mamadeira era preenchida por um leite que comprava em pó, um leite especial para gatos produzido por uma empresa chamada Nutripharme, que em seu site oficial descreve sua "missão" como sendo "a busca incessante de tecnologia e segurança para melhoria de seus produtos com profissionalismo, de forma a estimular novas técnicas e formatos para prevenção, tratamento e manutenção da saúde animal. Entre os produtos anunciados, um dos mais recentemente desenvolvidos chama-se AI-G, um suplemento vitamínico destinado a cachorros e produzido, segundo a descrição, “com ovos desidratados na forma de pó, selecionados a partir de galinhas White Leghorn que tiveram contato com antígenos de cães ${ }^{5}$." Embora a espécie Gallus gallus domesticus seja originária da Ásia, a história da raça Leghorn passa pela Toscana, na Itália, onde, segundo se diz, primeiro se desenvolveram, tendo dali chegado até as Américas, ainda no século XIX, saindo do porto de Livorno - donde seu nome atual, Leghorn, uma anglicização de Livorno. Estas galinhas são vastamente usadas hoje para produção de ovos no mundo inteiro, na maior parte das vezes em baterias, isto é, conjuntos de gaiolas cujo tamanho médio é de $432-555 \mathrm{~cm} 2$ e nas quais vivem entre 5 e 10 aves, deixando, para cada animal, um espaço menor que a área de uma folha de papel A4 - esta mesma na qual este trabalho foi impresso. Essas gaiolas impedem a quase totalidade das expressões de comportamento das galinhas, tais como "construir ninho, empoleirar, tomar banho de areia, ciscar, forragear, explorar seu ambiente, correr, saltar, voar, alongar e bater as asas, e até mesmo caminhar livremente." O site da Nutripharme, que afirma trabalhar "para a saúde e o bemestar animal", não especifica o sistema de criação das galinhas cujos ovos são usados para a produção do AI-G.

Voltando ao leite salvador da vida dos gatos que trouxe para viverem comigo e que contém uma série de nutrientes essenciais para o desenvolvimento deles, a Nutripharme não chega a detalhar sua origem. Sobre seu uso, ele é indicado como

\footnotetext{
${ }^{4}$ http://www.nutripharme.com.br/institucional.php?codigo $=1$.

${ }^{5}$ http://www.nutripharme.com.br/produtos.php?categoria=AI-G.

${ }^{6}$ Informações colhidas do site: http://www.confinamentoanimal.org.br/fique-pordentro/gaiola-em-bateria-galinhas.asp.
} 
substituto do leite em casos de privação do leite materno, tais como: morte da mãe, ausência de produção de leite (agalaxia), rejeição do filhote pela fêmea, neonatos muito fracos que não conseguem amamentar sozinhos, ninhadas muito grandes em que a mãe não produz leite suficiente, partos muito longos, etc. ${ }^{7}$

O caso de Bruxo e Nausicaa - como os nomeamos - não está exatamente especificado ali. Foram encontrados sozinhos e fracos, isto é, já sem a mãe há algum tempo. Posso especular: a mãe os rejeitou ou sofreu um desaparecimento forçado ${ }^{8}$ ? Foram separados dela contra as suas vontades e despejados ali? Se a mãe morreu ou não, não se pode ter certeza, já que nunca houve a evidência de um corpo. A relação da comunidade humana em cidades grandes com gatos errantes torna possíveis ou até prováveis ${ }^{9}$ todas essas hipóteses e outras mais. Mas, por terem sido encontrados neste condomínio no qual vivo, acredito poder restringir um pouco as possibilidades. A ampla área verde aqui favoreceu o surgimento de uma pequena colônia de gatos, todos muito parecidos, certamente parentes em algum grau. Há moradores que os consideram pragas - gatos caçam passarinhos, é verdade. Mas desconfio que não sejam só os gatos que entram nessa categoria de pestes, que parece autorizar os seres humanos a dispor deles

7

http://www.nutripharme.com.br/produto.php?codigo=13\&produto=SUPPORT\%20MILK\%20CAT

${ }^{8}$ Segundo a ONU, um desaparecimento forçado ocorre quando "pessoas são presas, detidas ou sequestradas contra sua vontade [...] por oficiais de diferentes setores ou níveis do governo ou por grupos oficiais ou privados agindo em nome de, ou com o apoio, direto ou indireto, consentimento ou aquiescência do governo, seguido de recusa em revelar o destino ou o paradeiros das pessoas concernidas ou uma recusa de reconhecer a privação de sua liberdade, o que coloca tais pessoas fora da proteção da lei" (em http://www.un.org/en/events/disappearancesday/background.shtml). Embora não seja sempre o caso, em muitos desaparecimentos forçados dão-se a morte e ao ocultamento do cadáver da vítima. Essa é claramente a descrição de um procedimento de governos que envolve humanos e a expressão é utilizada, no texto, de forma provocativa com a intenção de fazer vacilar o estatuto dos animais em nossa sociedade.

9 Uma pesquisa do IBGE de 2013 calculou a existência de 22,1 milhões de gatos domiciliados no país (cf. PNS, 2013, p. 26). Não há dados empíricos sobre o número de gatos errantes no Brasil, mas uma informação replicada em diversos veículos de imprensa atribui à OMS uma estimativa de cerca de 10 milhões (cf. por exemplo https://www.ufpe.br/agencia/clipping/index.php?option=com content \&view=article \&id=20367:ca es-e-gatos-para-serem-adotados\&catid=34\&Itemid=122

https://anda.jusbrasil.com.br/noticias/100681698/brasil-tem-30-milhoes-de-animais-abandonados). Grande parte dos centros de controle de zoonoses do Brasil pratica eutanásia, em animais doentes e sadios. Além disso, embora os maus-tratos a animais sejam tipificados como crime no país (Artigo 32 da Lei Federal de 12/02/1998), apenas em 2015 uma pessoa foi condenada à pena de prisão por maus-tratos e morte de animais (cf. http://www.anda.jor.br/18/06/2015/sentencahistorica-condena-matadora-animais-12-anos-prisao-brasil); sua prisão foi, entretanto, revogada por um desembargador (cf. http://g1.globo.com/sao-paulo/noticia/2015/06/condenada-por-mortede-caes-e-gatos-tem-prisao-revogada-em-sp.html). Embora não haja dados precisos, os envolvidos em proteção animal no país são unânimes em denunciar os altos números de ações cruéis praticadas contra animais errantes. 
como bem entendem, e não falo apenas de ratos, por exemplo: o sumiço (para não dizer abate ou assassinato) a que foram submetidos todos os gambás que viviam no condomínio é uma pista da relação que muitas vezes se estabelece entre as diferentes espécies de moradores de um mesmo espaço. A experiência leva então a pensar que a gata-mãe pode ter sido morta - envenenada, atropelada - ou capturada e despejada em algum lugar distante. De todo modo, não hesitaria em classificar seu destino como um desaparecimento forçado.

Entendo que usar este último termo para me referir à situação de um animal (um bem, segundo nosso código civil), ainda pior, de um animal errante (que não pertence a ninguém), possa causar estranhamento e mesmo escândalo. Mas é justamente esse lugar complicado e trabalhoso que gostaria de explorar. Esclareço, em primeiro lugar, que não pretendo, ao usar uma expressão oriunda do discurso de direitos humanos no contexto de crimes cometidos por organizações políticas ou pelo Estado, apagar as diferenças e singularidades que existem entre desaparecidos animais e desaparecidos humanos. Por outro lado, minha intenção é justamente procurar fazer transbordar o escopo do que se considera político e das redes de relação e responsabilidade civis e estatais.

Trouxe Bruxo e Nausicaa para viverem comigo porque não acredito que a cidade na qual vivemos possa lhes proporcionar, não digo uma vida sem perigos pois em toda vida há perigos -, mas uma sobrevida sem perseguições. A diferença de expectativa de vida, para ficar em só um dos fatores, entre um gato errante e um gato que vive em casa com humanos pode ser abissal (há entidades que calculam uma expectativa de vida de 2 anos para gatos rua contra cerca de 20 se domiciliados). E é claro que essa decisão, complexa, assimétrica mas não inteiramente unilateral, além de mudar nossas vidas, cada uma a seu modo, também trouxe consequências nem sempre favoráveis a eles. Por exemplo, para não terem que ocupar essa verdadeira zona de guerra contra seu povo, os gatos que vivem comigo passaram a viver confinados em um apartamento de $86 \mathrm{~m} 2$. Não têm acesso à rua, em parte porque não querem - já tentei levá-los com coleira para passear, o que recusaram -, em parte porque não podem. Foram castrados, pois se os deixasse às suas próprias vontades, teriam enchido nosso apartamento de filhotes, que não teríamos como sustentar. Vivendo aqui eles têm abrigo, alimentação, cuidados médicos, contato um com o outro e conosco. Nós brincamos juntos, dormimos juntos, muitas vezes divido minhas refeições com 
eles. Tudo isso não impede que sua situação se encaixe perfeitamente naquilo que disse o escritor e artista plástico John Berger no ensaio "Why look at animals?", sobre o desaparecimento dos animais do mundo contemporâneo, no momento em que ele fala dos animais de estimação, os pets:

A pequena unidade de habitação familiar carece de espaço, terra, outros animais, estações, temperaturas naturais e assim por diante. O pet é ou esterilizado ou sexualmente isolado, privado de quase qualquer outro contato animal e alimentado com comidas artificiais. Este é o processo material que jaz por trás do truísmo de que os pets vêm a se parecer com seus mestres ou mestras. Eles são criaturas do modo de vida de seu dono (Berger, 2009, p. 24-25).

Nausicaa, quando termina de comer a ração que lhe é oferecida em uma vasilha de cerâmica em cima do chão de taco, cava sem sucesso a madeira, tentando enterrar o que sobrou. Bruxo adora sapatos, esfrega-se neles, cheira as solas, morde-os. Meu companheiro costuma dizer que é saudade da terra.

\section{2.}

\section{A velha dos gatos}

Gilles Deleuze e Félix Guattari, em "Devir-intenso, devir-animal, devirimperceptível" de seu livro Mil Platôs, distinguem três tipos de animais: "individuados, familiares familiais, sentimentais, os animais edipianos, de historinhas, 'meu gato', 'meu cachorro"'; “os de gênero, de classificação ou de Estado, tais como os grandes mitos divinos os tratam, para deles extrair séries ou estruturas, arquétipos ou modelos"; e, finalmente, "animais mais demoníacos, de matilhas e afetos e que fazem multiplicidade, devir, conto..." (Deleuze e Guattari, 2005, p. 21-22). Indagam-se, entretanto, se "todos os animais não podem ser tratados das três maneiras" e, no mesmo parágrafo, afirmam que "todos aqueles que amam os gatos, os cachorros, são idiotas" (idem).

Pensando em todas essas afirmações, onde nos encontramos, eu, Bruxo e Nausicaa? É certo que eu os amo e que funcionei, para eles, em seus primeiros dias, como uma substituta de sua mãe, imitando seus gestos e cuidados, alimentando-os com leite produzido pelo trabalho de uma vaca leiteira, provavelmente com uma grande dose de sofrimento, e modificado pelo trabalho de humanos dedicados ao bem-estar de pets. Será que, por isso, concluindo com os mesmos autores, os gatos me "convidam a regredir, arrastam-[me] para uma contemplação narcísica"? (idem). Mas, nesse caso, não seria esse convite o 
resultado de uma relação possivelmente pré-imposta por mim, uma "relação humana com o animal", como eles chamam o tipo de relação familiar que certas pessoas constituem com seus gatos e cães? E mesmo Deleuze, de modo um pouco complacente, concede que "até o gato, até o cachorro..." (idem, p. 22) podem escapar desse tipo de relação - enquanto até piolhos ou elefantes podem se tornar familiares; ou, no Abecedário, que "ao mesmo tempo, o que digo é bem bobo, porque as pessoas que gostam verdadeiramente de gatos e cachorros têm uma relação com eles que não é humana" (Deleuze, 1996). Para Deleuze e Guattari, a relação a ser cultivada com um animal deve ser uma "relação animal". Sinto-me presa entre esses dois mundos com Bruxo e Nausicaa. Ao agir como mãe-outra para eles, dando-lhes mamadeira a cada duas horas por mais de quinze dias e ajudando-os como sua mãe-própria os ajudaria em suas necessidades, estava eu capturando-os para meu mundo humano ou sendo capturada para o mundo deles? A proeminência, no nosso arranjo impróprio, improvisado e entretanto pleno de técnicas humanas e felinas, recaía sobre que mundo? Ao agir como sua mãe, ou realizando as tarefas que sua mãe teria realizado caso estivesse com eles, transformava-me a mim em gata ou transformava-os a eles em humanos?

Essas perguntas, sei que só as posso fazer de dentro de minha "pequena unidade de habitação familiar", onde vige uma assimetria entre mim e eles. Aqui, posso mais que eles. Não quer dizer que eles não possam nada, mas que não estamos diante uns dos outros em termos de igualdade total - o que seria isso, aliás? Já no condomínio em que moramos, com sua área verde, há outros gatos, parentes ou não de Bruxo e de Nausicaa. Ali, os termos de convivência são outros. Há árvores, grama, passarinhos, havia gambás também. Há um estacionamento repleto de carros dos outros condôminos. Há funcionários do condomínio e condôminos, humanos que alimentam gatos, outros que os toleram e também os que os envenenam ou pagam outras pessoas, geralmente de condição social inferior, para capturá-los e os soltarem fora dali, longe, em outros condomínios ou em terrenos baldios, quem sabe na periferia, para que se tornem "problema" de outrem.

Para Deleuze e Guattari, como dito acima, podem-se distinguir três tipos de animais; mas quantos tipos de humanos seríamos capazes de diferençar? Há também o espaço fora do condomínio, nosso bairro, há a cidade. Nas vias públicas a nosso redor, há carros que correm e cujos motoristas nem sempre desviam de 
animais. Aquele pequeno gatinho que persegui fracassadamente pouco antes da chegada de Bruxo e de Nausicaa foi atropelado por um deles ao deambular para fora da cerca que separa o conjunto de prédios, seu pequeno bosque, jardins, estacionamento, salão de festas e academia de ginástica da rua. Meu interfone tocou uma noite, com um pedido de ajuda de uma moradora do tipo que alimenta os gatos. O filhote, então já com uns seis meses, havia sido retirado da via por um humano, talvez um dos compassivos moradores, e pousado sobre uma faixa de grama, aparado por uma árvore. Não se movia. O atropelador não havia parado para saber dele. Não é nada fácil para um gato viver na cidade. Fomos, eu, ela e o gatinho, a uma clínica veterinária 24 horas. Foram necessárias semanas de cuidados, visita a um neurologista especializado em pequenos animais e um bocado de dinheiro até que o gatinho ficasse bem. No começo, só conseguia se virar para um lado, só respondia a estímulos de um dos lados da face; o neurologista nos explicou que se tratava de uma lesão no cérebro mas que, como ele era jovem, muito provavelmente conseguiria compensá-la e voltar a ter todos os movimentos do corpo. Isso de fato aconteceu e ele foi viver com a mulher que me interfonou. Como ela mora no andar térreo, ele pode passear pelo jardim e pelo bosque até voltar para casa pulando pela janela; tem acesso tanto ao apartamento em que vive quanto à área do condomínio. Que eu saiba, não voltou a se aventurar para fora da cerca. Será que aprendeu uma lição? Conjecturo que este arranjo seja melhor para o gato do que o que posso negociar com Bruxo e Nausicaa, mas nunca se tem todas as escolhas à disposição na vida.

Por causa dos perigos e perseguições a que estão sujeitos nos espaços da cidade sem que haja contrapartida para eles, isto é, algum direito formal que lhes seja assegurado - há alguma legislação a seu favor, é verdade, mas de aplicação difícil e rara, sobretudo para esse tipo de animal citadino errante -, por vezes imagino que os gatos que vivem comigo chegaram aqui um pouco como refugiados políticos. Não gosto do termo resgatar nem do vocabulário salvacionista que se costuma empregar para falar de comunidades como a nossa, tampouco do termo adotar, embora por vezes o use por falta de alternativa melhor. Não considero que salvei Bruxo e Nausicaa ao trazê-los para viver comigo; não os "resgatei" das ruas, porque as ruas e a cidade não deveriam ser, necessariamente e às vezes não são de fato - um lugar de impossível coabitação multiespecífica. 
Não os adotei se por adotar entendermos perfilhar no sentido sumamente humano que filho, família e parentesco têm comumente.

Penso na figura de Elizabeth Costello, personagem de J. M. Coetzee; não a Costello conferencista aguerrida e pessoalmente desesperada de A vida dos animais (1999), mas a senhora de "The old woman and the cats" (2013), que se retira para a região de Castela, na Espanha, onde decide passar sua velhice numa casa antiga rodeada de gatos semisselvagens. Neste conto, ao contrário da novela de 1999, é John, o filho de Costello, quem a visita; estamos, então, em seu território, não mais no espaço acadêmico em que se passa $A$ vida dos animais e que ela parece abominar. E, se a primatóloga Barbara Smuts pôde, em seu artigo da série de reflexões que se seguem à novela, estranhar e criticar como um "surpreendente lapso" (Smuts, 2009, p. 129) "a falta de referência a relações com animais na vida real" (idem) - mesmo que aventasse a possibilidade de que essa falta pudesse ser devida ao "ainda forte tabu acadêmico contra referências à experiência pessoal" (idem) -, em "The old woman and the cats" os gatos proliferam e podemos acompanhar a relação da velha Costello com eles. Ela, ao ser indagada por John a respeito de sua relação com esses bichos, resolve lhe contar a "história toda dos gatos - minha e dos gatos" (Coetzee, 2013, p. 21). E o que a personagem-escritora narra é que os gatos da localidade em que vivia, os muitos gatos que havia por ali, eram todos arredios, avessos ao contato com humanos. Que a relação entre humanos e gatos ali era de pura inimizade, os primeiros algozes dos segundos. E que um dia, durante uma caminhada, avistou uma gata parindo em um bueiro; impedida de fugir por estar no meio do parto, a gata rosnou para Costello: "Uma pobre e malnutrida criatura, tendo seus filhos em um lugar imundo e úmido, e ainda assim pronta a dar sua vida para defendê-los" (idem, p. 22). Ela então explica que se sentiu, ali, naquele momento, interpelada: "Eu também sou mãe" (idem). Decidiu, assim, de pronto e sem nenhuma racionalização, que "na questão dos gatos, daria as costas para a minha própria tribo - a tribo dos caçadores - e tomaria o partido da tribo dos caçados” (idem).

Nausicaa e Bruxo eram tão pequenos e indefesos quando os conheci que me arrisco a afirmar que eu também senti-me interpelada ali por eles - não por algum sentimento materno, pois não sou mãe - e tomei partido deles. No momento em que os vi, num cômodo do apartamento de um prédio vizinho ao meu, respondi. Sem cálculo, sem argumentos racionais, eu também respondi. E, ainda que, como 
continua Costello, "um gato não [seja] um conjunto de questões" (idem), não pude me furtar a tentar compreender que experiência é essa que divido com eles, que nos determina diariamente em nossa própria carne. Assim como Costello,

Não quero viver em um mundo em que um homem usando botas tira vantagem do fato de que você está parindo, indefesa, incapaz de escapar, para pisoteá-la até a morte. Tampouco quero viver em um mundo no qual meus filhos ou os filhos de qualquer mãe sejam arrancados dela e afogados porque alguém decidiu que eles são demais (idem, p. 23).

Por outro lado, diferentemente dela, esta para mim não é uma questão de maternidade, de um sentimento atravessado e experimentado por fêmeas que têm filhos. E, ainda que admire a sua pura resposta, uma resposta codificada, claro, por sua condição de mãe, mas ainda assim uma resposta que, segundo Costello, não vem do cálculo, e me reconheça tendo também respondido, não consigo não deixar de pensar em meu caso particular, no tipo de relação que, após a resposta ou habitando-a mais demoradamente -, desenvolvi com Bruxo e Nausicaa. O vocabulário da adoção não me parece suficiente pois o percebo contaminado por uma ideia de parentesco exclusivamente humano e uma relação estanque com os animais: eles sempre infantilizados diante da maioridade humana. Não penso absolutamente que seja esta a natureza em que meu encontro com os gatos se dá; ainda mais, acredito que uma imposição de minha parte a que se mantivessem nesse eterno estado infantil ("meus filhinhos") seria uma violência diante de nossas diferenças. No entanto, não seria despropositado pensar que formamos um vínculo que é um tipo de parentesco transespecífico por afinidade.

Que toda essa reflexão tenha surgido a partir da ideia de uma "resposta" se compreenderá melhor se nos remetermos à filósofa Donna Haraway, que insiste, salientando a conexão entre responder e responsabilidade, em que esta última deve ser entendida como "habilidade de responder" (response-ability). Uma primeira consequência do conceito de responsabilidade como "uma relação urdida em intra-ação através da qual entidades, sujeitos e objetos, vêm a ser" (Haraway, 2008, p. 71) é que ela deixa de ser apenas humana. O termo fundamental nessa definição proposta por Haraway é "intra-ação", um conceito da física e filósofa Karen Barad. Barad, inspirada por Niels Bohr e seu Princípio de Complementaridade, desenvolveu uma teoria onto-ético-epistemológica chamada realismo agencial (cf. Barad, 1996), a qual postula que o mundo é composto por fenômenos considerados como relações particulares materializadas que incluem 
elementos humanos e não-humanos emaranhados (entangled); aquilo que chamamos indivíduos somente viriam à existência dentro e através dos fenômenos e nunca de uma vez por todas. No lugar do chamado "corte cartesiano" entre res cogitans e res extensa, na intra-ação um "corte agencial" é implementado (enacted), criando assim uma separação entre sujeito e objeto que só existe dentro do fenômeno. Não existem agentes individuais, mas agências implementadas dentro dos fenômenos através dos cortes: "É através de intra-ações agenciais específicas que os limites e propriedades de 'indivíduos' dentro do fenômeno tornam-se determinados e articulações materiais particulares do mundo se tornam significativas" (Barad, 2012, p. 77). Isto é, no lugar da interação, do encontro de dois ou mais não divisíveis - de indivíduos - , as competências, capacidades e limites em cada caso particular emergem, vêm à existência "por meio de e como parte de sua intra-relação emaranhada [entangled]" e são "reconfigurados iterativamente através de cada intra-ação" (idem, 2007, p. ix).

Dito de outro modo, e no meu caso particular, nem eu nem Bruxo ou Nausicaa existimos como humana e gatos previamente, com tudo o que tais categorias trazem consigo, com responsabilidades e capacidades distribuídas previamente; mas é no fenômeno, ou melhor, em todos os fenômenos de que fazemos parte que passamos a existir como entidades separadas com competências e responsabilidades distintas e não-simétricas. Não há de antemão nem um "eu" nem um "eles", mas emaranhamentos dos quais podemos emergir eu, Bruxo e Nausicaa em situações particulares segundo relações materiaissemióticas. Somos ambos "sujeitos e objetos uns para os outros em intra-ação fluente" (Haraway, 2008, p. 71).

Ademais, diz Haraway, "se esta estrutura de relações materiais-semióticas se quebrar ou se não se permitir que ela nasça, então nada resta além da objetificação e da opressão" (Haraway, 2008, p. 71). E, ainda que a frase anterior, de When Species Meet, surja em um contexto referente a animais de laboratório e cientistas, a filósofa sublinha que "animais em todos os seus mundos são responsáveis no mesmo sentido em que as pessoas o são" (idem). Isso vai de encontro à infantilização dos animais e ao vocabulário da adoção. Em meu caso, respondi aos gatos quando nos vimos pela primeira vez; mas, não menos importante, eles também responderam a mim. Somos responsáveis diante uns dos outros, somos outros uns para os outros, surgidos de emaranhamentos nos quais cortes são 
implementados reiteradamente. Se eu nos impusesse unilateralmente a figura mãefilhos, estaria impedindo a fluência das "relações materiais-semióticas", suprimindo violentamente a possibilidade de uma agência criadora e responsável por parte deles diante de mim, que de outro modo poderia ser cultivada assimetricamente em conjunto, com resultados novos e imprevistos para mim e para eles.

Donna Haraway, que também não é mãe e tem uma longa experiência de convívio com cães, fala em espécies companheiras e significant otherness (cf. Haraway, 2016a). Este último é um termo difícil de traduzir, um jogo com significant other, que quer dizer companheiro, parceiro, enfatizando o "outro" da fórmula, substantivando-o: algo como alteridade significativa $\mathrm{O}$ âmbito de uma alteridade significativa me parece ser respeitoso diante das dessemelhanças entre mim e os gatos, sem subestimar nossos laços. Parafraseando Haraway, constituímo-nos ambos mutuamente como outros significativos em nossa pequena comunidade.

\section{3. \\ "Expulsos do espaço urbano"}

E então, no começo de 2014, chegou até nossa pequena unidade familiar um outro gato. Com três meses à época, saiu da caixinha de transporte e correu para se esconder debaixo da mesa. Uma vizinha, a mesma do gato atropelado, havia me perguntado no dia anterior se eu poderia ou gostaria de receber mais um gato. Disse a ela que iria pensar, afinal meu apartamento não é grande e me parecia que eu, Marco Antonio, Bruxo e Nausicaa já éramos o suficiente aqui. No dia seguinte, entretanto, ela bateu em nossa porta portando a caixinha de transporte com o filhote. Essa vizinha, junto com uma veterinária, fazia um trabalho de captura-esterilização-devolução com os gatos do condomínio como modo de controle da população, um tipo de projeto realizado por inúmeras pessoas no mundo todo, política pública em algumas localidades, como método substitutivo ao de tipo captura-eutanásia. O filhote trazido a meu apartamento, ela me explicava, era o último da ninhada de uma gata que vivia entre os prédios; assim que o período de amamentação terminara, a gata-mãe fora capturada, separada de seus filhotes, castrada e devolvida ao condomínio. O destino dos pequenos foi 
outro: todos haviam encontrado humanos que os acolheram em suas casas. Todos menos um: este filhotinho que ela me trazia, recusado por ser, em suas palavras, "muito feio e antissocial." Não posso deixar de comentar que, à guisa de explicação do motivo da feiura do bichinho, ouvi insultos racistas que, dirigidos a um gato de pelagem preta, deram a ver a perniciosidade e pervasividade, capazes de atravessar barreiras específicas, da questão racial na sociedade em que vivemos.

Chamamos esse gato, pequenino, barrigudinho e apavorado, de Batatinha. Batatinha chegou aqui como o fruto de uma situação marcada por questões de raça, classe e gênero, oriundo de uma família de gatos errantes que, tendo já nascido pobres, não eram exatamente livres. Crianças andavam atirando pedras contra a gata-mãe e seus filhotes, conforme fiquei sabendo, o que provocou a pressa da vizinha e da veterinária em capturá-la, esterilizá-la e desfazer aquela pequena e precária família na esperança de uma vida melhor para cada um deles. Batatinha ficou por último, o mais ligado à mãe; misantropo, me disseram, parecido com um "despacho de macumba." Seus primeiros dias conosco foram um desastre. Ele, cheio de medo dos humanos e curiosíssimo em relação a Bruxo e Nausicaa, que, como bons animais de território, o odiaram à primeira vista. Eu e meu companheiro procurávamos, meio perdidos, modos de mediar o cenário. Nos primeiros dias mantivemo-lo em um quarto que àquela altura funcionava como escritório para nós, informados por sites especializados em comportamento animal que orientavam os humanos responsáveis pela introdução de novos gatos em sua casa a separá-los a princípio e ir aos poucos fazendo a apresentação. Mas não eram apenas Bruxo e Nausicaa que não gostavam de Batatinha e precisavam de tempo; Batatinha sentia tanto pavor de nós que mal o víamos nesse começo. Toda vez que entrávamos no quarto que agora era dele, o gatinho estava desaparecido, no alto do armário de preferência, escondido atrás de alguns vasos de plantas. Sabíamos que estava ali apenas por seus sinais: caixinha de areia usada e vasilhas de comida e água vazios. À noite, esses sinais se tornavam impossíveis de negligenciar. Ouvíamos, dos outros cômodos da casa, uma sinfonia triste composta por miados longos e agudos. Era claramente um tipo de lamento. Será que chamava a mãe?, nos perguntávamos, já que ele se posicionava no peitoril da janela para começar sua ululação à noite escura. 
Foi meu companheiro quem primeiro conseguiu estabelecer contato, aproximando-se do gatinho, suportando suas recusas, por vezes agressivas e defensivas, e fazendo carinho nele até que finalmente cedesse. Isso não demorou muito. Logo começamos a deixar todos os gatos juntos, para que se conhecessem. Batatinha exibia então um comportamento curioso. Submetia-se aos outros, posicionava-se de modo absolutamente inofensivo, quase como oferecendo seu corpo a Bruxo e Nausicaa. Parecia dizer: "não ofereço perigo, não pretendo disputar o território". Estes, que o perseguiam, quando finalmente o encontravam imóvel, exposto e desamparado, recuavam. Não o atacavam. A hostilidade direcionada ao filhote transformava-se lentamente em curiosidade. Cheiravam-no, exibiam pequenos gestos de dominação, certificando-se de que a casa ainda era deles. Após diversos dias de repetição desta mesma dinâmica, Batatinha finalmente os conquistou, tornando-se o caçula da turma. A partir daí deixou de ser uma ameaça e se transformou em alguém que Bruxo e Nausicaa protegiam, de quem cuidavam, a quem ensinavam - encontrei Bruxo em muitas ocasiões se limpando ao lado de Batatinha, que até ali não era muito cioso de higiene corporal. Aos poucos o filhote passou a imitar o mais velho até mostrar o mesmo cuidado com a limpeza. Nessa época, o mais impressionante no que dizia respeito ao modo como se desenvolvia a relação dos três era a argúcia social de Batatinha. Era como se ele se soubesse minoria, mais fraco, e tivesse lançado mão de uma estratégia de submissão para conquistar os donos do território. Uma estratégia tremendamente bem sucedida, é preciso frisar; de intruso alarmante passou depressa a protegido.

Não pude deixar de pensar que ali se elaborava uma pequena política, com nosso apartamento, o mundo deles, fazendo as vezes de palco de uma reduzida cidade onde encontraram abrigo. A imagem do refugiado político então retorna. A minha cidade, humana, é hostil à presença de animais errantes; há muito tempo que, por diferentes processos civilizatórios, os animais tornaram-se presenças indesejáveis nas ruas. A antropóloga Nádia Farage, em um artigo intitulado "No collar, no master: workers and animals in the modernization of Rio de Janeiro 1903-1904," conta que, no começo do século XX, epidemias e surtos de doenças como varíola, febre amarela e peste bubônica castigavam o Rio de Janeiro, causando enormes perdas humanas e materiais para a cidade, o que levou o governo federal a apontar Oswaldo Cruz, que havia estudado no Instituto Pasteur, 
na França, como Diretor-geral da Saúde Pública, e Pereira Passos como prefeito da cidade com o objetivo de modernizá-la, o que não se poderia fazer sem sua higienização. Procedeu-se assim ao que ficou conhecido por "bota-abaixo", remoção forçada de moradores de cortiços e favelas, que foram demolidas sob o argumento da necessidade de destruição de focos de doença, mas também para que as estreitas vias públicas fossem alargadas de modo que se pudesse criar, em cima dos escombros, uma nova cidade cujo ideal era Paris. Isso não aconteceu sem consequências para os animais:

À medida que micróbios e bactérias entraram no imaginário popular, inversamente vacas, porcos, cachorros e outras espécies foram, a partir daquele momento, expulsos do espaço urbano e tornados invisíveis aos moradores. O modelo sanitário, que veio à existência no começo do século vinte, persistiria dali em diante e, em sua forma mais agressiva, regularia as vidas dos animais, concebendoos como mercadorias cujo excesso seria descartável na cidade moderna. Intrusos eles seriam, co-moradores nunca mais (Farage, 2013, p. 3-4).

Já havia, no Rio de Janeiro, pelo menos desde 1838, leis que regulavam e proibiam a livre circulação de bichos pela cidade - estabelecendo ali a própria categoria de animal errante [stray] como um problema público e destinando, já em 1892, os cães apreendidos nas ruas à experimentação científica - mas, segundo Farage, não foi senão a partir do esforço urbanístico civilizatório de Pereira Passos que regras desse tipo foram de fato colocadas em prática. É a fundação da cidade moderna ela mesma que promove a expulsão de animais de criação para áreas afastadas ou rurais e a criação de matadouros públicos também nestas localidades para

evitar a fuga causada por pânico do gado pelas ruas, então uma ocorrência comum, causando nos moradores da cidade grande alarme e talvez alguma preocupação com os animais apavorados, que muitas vezes procuravam refúgio em casas próximas ou mesmo em igrejas (Farage, 2013, p. 10).

São o "sofrimento e a morte dos animais" eles mesmos que são escondidos "das sensibilidades urbanas" (idem, p. 4).

Em Curitiba, embora a Câmara Municipal tenha ordenado ainda em 1864 que o abate de animais se realizasse em matadouros públicos ou particulares, apenas em 1878 o primeiro matadouro foi inaugurado, conforme contam as pesquisadoras Zulmara Clara Sauner Posse e Elizabeth Amorim Castro, autoras do livro Os 75 anos do Matadouro Municipal de Guabirotuba. Arquitetura, urbanização e higienismo. Por "estar classificado como estabelecimento "perigoso, insalubre e incômodo" (Castro e Posse, 2015, p. 13; grifo meu), a 
instalação deveria ser construída, conforme a Lei Provincial n. 409 de 15 de abril, "nos subúrbios da cidade" (idem). Este primeiro matadouro, situado na esquina da rua Itupava com a Sete de Abril, funcionou por pouco tempo, tendo sido aberta uma concorrência para a construção de um novo ainda em 1890. Em 1896, o jornal paranaense A República urgia por sua remoção, argumentando "que além de situado muito próximo da cidade, está imprestável e é um foco de infecção cercado de guaxeiras e outras immundícias" (A República, 27/10/1896, p. 1; grifo meu). Em 1899, com festa e churrasco, foi inaugurado o novo matadouro municipal em Guabirotuba, onde funcionou até 1974 sem jamais deixar de receber críticas quanto à sua adequação; depois de seu fechamento, o prédio foi ocupado entre 1988 e 2008 pela Associação dos Meninos e Meninas de Rua de Curitiba. Segundo uma matéria de A Gazeta do Povo sobre o livro de Castro e Posse, durante o tempo em que o matadouro funcionou, "volta e meia, cartas dos moradores do Guabirotuba reclamavam da 'falta de compaixão' com os animais à espera do abate" (Fernandes, 2015, s/p).

Não foram, porém, apenas os animais de criação o alvo das leis que procuravam edificar um novo mundo: as espécies companheiras, gatos, mas principalmente cachorros, também se tornaram ilegais. O recolhimento de cães e gatos errantes com vistas à eutanásia vigorou, no Rio de Janeiro, pelo menos até 1997; em Curitiba, até 2005. É possível ler nos jornais do começo do século XX notícias que exaltavam o trabalho das carrocinhas por livrarem as cidades de seus indesejados invasores, como esta, de 2 de setembro de 1907: "A Câmara Municipal continua a pega dos cães vagabundos que infestam as ruas de nossa capital. Às 9 horas da manhã de hoje a carrocinha gaiola passou pela rua 15, já quasi abarrotada de rafeiros" (A República, 02/09/1907, p. 2). Ataques políticos, como o de Marins de Camargo a João Menezes Dória, que aparece em destaque na primeira página de A República em dezembro de 1919, lançavam mão da figura do cão errante como um bicho pestilento e agressivo, diante de quem se deveria reagir com violência:

O que faria uma pessôa sensata e de responsabilidade que ao passar por uma rua ou uma estrada fosse inopinadamente atacado por um cão surrado e lazarento? Certamente continuaria o seu caminho sem voltar siquer o olhar para o mastim nojento, enquanto este se limitasse a ladrar e a ganir. [...] Quando o rafeiro tem a ousadia de querer nos morder os calcanhares, dá-se-lhe um ponta de pé na focinheira asquerosa ou quebra-se-lhe uma bengala no sovado lombo (A República, 24/12/1919, p. 1). 
E era mesmo na categoria de peste que se encaixavam os cães errantes dentro da moderna visão de mundo que se consolidava nas cidades brasileiras. Comentando uma crítica satírica do periódico $O$ Rio $N u$, em 1904, à guerra contra os animais declarada por Oswaldo Cruz, Farage afirma que é a reunião de incontáveis animais, como mosquitos, ratos, vacas, porcos e cães sob o rótulo de peste que constitui a "rota pela qual o processo de eliminação ou expulsão chegou até os animais domésticos" (Farage, 2013, p. 9). A consolidação dessas categorias por políticas públicas se insere, segundo a autora, no "quadro maior da biopolítica estatal" (idem, p. 2), da gestão da nascente noção de populações, diferentemente do poder disciplinar, que atuava sobre indivíduos-corpos; a biopolítica, conceito do filósofo Michel Foucault de que Farage faz uso, entre outras coisas, intervém, pela medicina, nas questões de natalidade e morbidade, nas palavras do autor, através de uma "função maior da higiene pública, com organismos de coordenação dos tratamentos médicos, de centralização da informação, de normalização do saber" (Foucault, 2005, p. 291), mas também age no domínio das "relações entre a espécie humana $[. .$.$] e seu meio de existência [. .$.$] na medida em$ que não é um meio natural e [na medida] em que repercute na população [...]; um meio que foi criado por ela" (idem, p. 292). Foucault termina decretando: "Será essencialmente o problema da cidade" (idem). Em um outro artigo de Farage, pertencente ao mesmo projeto de "No Collar, No master", intitulado "De ratos e outros homens: resistência biopolítica no Brasil Moderno", a autora se declara inspirada pela antropóloga Manuela Carneiro da Cunha para realizar "uma antropologia histórica que convida a contemplar o sentido em escolhas e projetos políticos que, dissidentes ou mesmo derrotados, vivem nas entrelinhas das histórias oficiais" (Farage, 2012, p. 2). É possível resumir a proposta de Farage como uma tentativa de recuperação da situação dos animais nos projetos biopolíticos que fundam a cidade moderna, especificamente o Rio de Janeiro, e sua relação com as lutas populares - principalmente as situadas no movimento anarquista de cunho naturista - no mesmo contexto.

Nos dois textos supracitados, a antropóloga traça as aproximações e acoplagens multiespecíficas das resistências ao biopoder no momento em que a cidade moderna é criada; em "No Collar, No Master", o foco se encontra na retirada dos animais dos espaços públicos conjuntamente ao bota-abaixo que 
atingiu as camadas mais pobres da população e nos atravessamentos multiespecíficos que se manifestavam nas demonstrações populares, como ataques a carrocinhas por operários com o objetivo de liberar os animais presos e artigos em jornais anarconaturistas. Em "De ratos e outros homens", são os discursos contra a vacinação obrigatória que se associam àqueles de repulsa à vivissecção, atividade sem a qual não se produziam vacinas. Em ambos os casos, Farage devolve as populações animais - seja sob a forma de animal de trabalho, peste, animal errante ou cobaia - ao grupo das populações geridas por ações biopolíticas estatais.

Mais uma vez, será que por este caminho, tendo em vista que a biopolítica também se exerce diante de animais considerados como membros de espécies cujas populações devem ser administradas, é justo pensar em Bruxo, Nausicaa e Batatinha como refugiados políticos? Na gata-mãe de Bruxo e Nausicaa como um caso de desaparecimento forçado? Talvez essas ideias ainda sejam uma torção de tais noções, mas parece que os animais também são interpelados pelo biopoder. O nascimento de nossas cidades modernas dá testemunho disso e é possível observar o mesmo fenômeno em atuais centros de controle de zoonoses, em práticas de manejo populacional de espécies silvestres que se encontram no caminho de criações de gado e plantações, em todo o aparato biotecnocientífico direcionado à veterinária e à zootecnia, na indústria farmacêutica e suas cobaias, no agronegócio que decide quem vive, quanto tempo é obrigado a viver, mesmo que nas condições mais lastimáveis, e quando e como um animal deve morrer e em tantos outros lugares. Isso significa também, como ensina Haraway, que:

A prática do olhar e da resposta não tem limites predefinidos, mas abandonar a excepcionalidade humana tem consequências que requerem que saibamos mais no fim do dia do que no começo e nos lancemos em alguns modos de vida e não em outros na jamais terminada biopolítica de espécies emaranhadas (Haraway, 2008, p. 295).

Acredito, assim, que ter respondido aos gatos ao trazê-los para viver comigo foi um ato político. Significou, para eles, a possibilidade, não de uma vida perfeita, não da melhor vida que poderiam ter absolutamente, entre todas as possibilidades imagináveis, mas de uma mudança em sua condição dentro da cidade. De pragas e strays tornaram-se companheiros meus. E, ainda que seja um torção, não posso deixar de narrar aqui sua história como a de perseguidos (bio)políticos refugiados em minha "pequena unidade familiar", neste ínfimo 
pedaço da cidade no qual seu estatuto como viventes é determinado de outro modo, com consequências para todos nós.

\section{4. \\ Indistinção e indiscernibilidade}

Ainda em "No Collar, No Master", Farage recorre a Giorgio Agamben e seu conceito de vida nua para falar dos animais tornados populações. Comentando mais uma sátira de $O$ Rio $\mathrm{Nu}$, que sugeria jocosamente o enjaulamento de "menores sem donos" como prosseguimento das políticas da prefeitura que faziam o mesmo com cães errantes, isto é, fazendo explicitamente a relação entre cães e menores de rua enquanto grupos indesejáveis na cidade higienizada, a autora afirma que

A imagem extrema de "vidas nuas", como Agamben agudamente as descreve, são vidas animais. Assim concebidas, dentro do cálculo biopolítico que está sob consideração aqui, "vida nua" é também "vida excessiva" - a multidão em seus números incontroláveis, sejam eles humanos ou animais. (Farage, 2013, p. 14).

É possível que, para Agamben, a vida nua seja mesmo equivalente à vida animal, mas apenas àquela parte animal presente no homem e não aos outros viventes assim chamados. Logo no início de Homo Sacer. O Poder soberano e a Vida Nua I, quando faz a distinção (segundo ele, oriunda do pensamento grego antigo) entre zoé, a "vida natural", compartilhada por homens, animais e deuses, e bíos, a "vida qualificada", fica claro que a segunda é prerrogativa dos humanos (cf. Agamben, 2002). Sendo a raça humana a única que existe ao mesmo tempo enquanto zoé e bíos, diz respeito apenas a ela o "conflito político decisivo, que governa todos os demais conflitos" (Agamben, 2007, p. 146), que faz com que a política ocidental seja "co-originariamente biopolítica", a saber, o conflito "entre a animalidade e a humanidade do homem" (idem; grifo meu), conforme explicitado pelo autor em $O$ Aberto. Isto é, para Agamben a biopolítica envolve a questão animal apenas na medida em que os humanos participam deste tipo de vida. Exclusiva possuidora de qualificadores, somente a vida humana, quando roubada destes, tornar-se-ia vida nua. Que a vida dos animais outros que humanos seja sempre zoé não poderia ser para eles nenhuma tragédia: ao contrário da antropogênese - o "tornar-se humano do vivente", que "completa e custodia a superação da phýsis animal em direção à história humana" (idem, p. 145) -, não 
haveria nenhuma "ailurogênese", “caninogênese", "porcinogênese” ou qualquer operação que fizesse sair gatos, cães, porcos ou outros animais da pura vida natural que experimentam. Ainda em O Poder Soberano e a Vida Nua, o autor chega a aproximar, seguindo o jurista alemão Rudolph von Jhering, a figura do direito romano homo sacer - pessoa banida que pode ser morta sem que isso constitua crime e que não pode ser sacrificada religiosamente, ou seja, que se encontra "no cruzamento entre uma matabilidade e uma insacrificabilidade, fora do direito humano quanto daquele divino" (Agamben, 2002, p. 81), paradigma da vida nua - à do wargus, o bandido, fora-da-lei, homem-lobo da antiguidade germânica (cf. idem, p. 111). Imagem híbrida de homem e animal, o wargus poderia ser morto sem que se cometesse homicídio; e é na sua mestiçagem, no emaranhamento homem-animal, que Agamben enxerga o traço decisivo de seu estatuto:

A vida do bandido - como aquela do homem sacro - não é um pedaço de natureza ferina sem nenhuma relação com o direito e a cidade; é, em vez disso, um limiar de indiferença e de passagem entre o animal e o homem, a phýsis e o nómos, a exclusão e a inclusão: loup garou, lobisomem, ou seja, nem homem nem fera, que habita paradoxalmente ambos os mundos sem pertencer a nenhum (idem, p. 112).

O que o estado de exceção, dispositivo pelo qual o soberano suspende a ordenação jurídica vigente sem a abolir as normas mas descontinuando direitos, isto é, criando uma zona de anomia, "um patamar de indistinção entre democracia e absolutismo" (idem, 2004, p. 13) no qual a vida humana, roubada de seu estatuto jurídico, pode se tornar vida nua - que é regra nos dias atuais ${ }^{10}-$, o que esse dispositivo cria é a possibilidade terrível, sempre à espreita, de que os homens venham a ser animalizados. É assim que o filósofo interpreta o Homo homini lupus hobbesiano: "não simplesmente besta fera e vida natural, mas, sobretudo, zona de indistinção entre humano e ferino, lobisomem, homem que se transforma

${ }^{10}$ Agamben, na conclusão de Estado de exceção, afirma que este "hoje, atingiu exatamente seu máximo desdobramento planetário. O aspecto normativo do direito pode ser, assim, impunemente eliminado e contestado por uma violência governamental que, ao ignorar no âmbito externo o direito internacional e produzir no âmbito interno um estado de exceção permanente, pretende, no entanto, ainda aplicar o direito" (Agamben, 2004, p. 131). O USA Patriot Act, que se seguiu aos atentados às Torres Gêmeas em 2001 e permite ao Estado deter estrangeiros suspeitos de atividades consideradas um risco para a segurança nacional norte-americana, é um exemplo de ordem que apaga o estatuto jurídico dos presos/acusados, lançando-os em uma zona de indistinção: não têm garantidos nem seus direitos segundo o ordenamento jurídico norte-americano tampouco aqueles dos prisioneiros de guerra segundo a Convenção de Genebra (cf. idem, p. 14). Nesse sentido, Agamben concorda com a filósofa Judith Butler, para quem o detido de Guantánamo constituiu "a vida nua em sua máxima indeterminação" (idem). 
em lobo e lobo que se transforma em homem: vale dizer, banido, homo sacer" (idem, 2002, p. 112). Em $O$ Aberto, ao declarar que já não há mais tarefas históricas destinadas ao homem, Agamben exprime a crença de que o que está em jogo atualmente - o livro foi publicado em 2002 - é "assumir como tarefa a própria existência fática dos povos, quer dizer, em última análise, sua vida nua" (Agamben, 2007, p. 140; grifo meu), explicando em seguida a aporia em que nos encontramos hoje, do seguinte modo:

[...] não há outra opção, para uma humanidade tornada novamente animal, que a despolitização das sociedades humanas através do desenvolvimento incondicionado da oikonomía, ou seja, a assunção da vida biológica mesma como tarefa política (ou melhor, impolítica) suprema (idem, p. 140-141).

Para o filósofo, o problema do que ele chama de máquina antropológica é que ela, a cada vez que separa, no homem, animalitas e humanitas, também faz surgir a vida nua, esta figura de uma humanidade bastarda e defraudada.

A expressão usada por Agamben nas formulações a respeito da vida nua lembra a "zona de indiscernibilidade" de Deleuze e Guattari, o meio mesmo de seu conceito de devir, sobretudo tal como ele aparece em Kafka, pour une littérature mineur e Mille Plateaux. Devir é um tipo de relação intensiva, "movimento que desterritorializa ambos os termos da relação que ele cria, extraindo-os das relações que os definiam para associá-los através de uma nova conexão parcial" (Viveiros de Castro, 2015, p. 184), "movimento instantâneo de captura, simbiose, conexão transversal entre heterogêneos" (idem, p. 186), "diferença na prática" (idem, p. 183), situada sobre "uma economia de afetos transespecíficos que ignoram a ordem natural das espécies e suas sínteses limitativas" (idem, p. 187), para usar as palavras do antropólogo Eduardo Viveiros de Castro. Dizem os autores: "se o devir é um bloco (bloco-linha) é porque ele constitui uma zona de vizinhança, de indiscernibilidade, um no man's land [...]" (Deleuze e Guattari, 2005, p. 91). Mas ali onde Agamben vê o maior perigo, Deleuze e Guattari situam, de modo quase inverso, uma linha de fuga, aquele "minúsculo riacho, sempre corre[ndo] entre os segmentos, escapando de sua centralização, furtando-se à sua totalização" 11 (idem, 2004, p. 94): "uma fibra vai

\footnotetext{
${ }^{11}$ Para os autores, o homem é segmentarizado "por todos os lados e em todas as direções" (Deleuze e Guattari, 2004, p. 83). Eles então distinguem três tipos de linhas: as molares, duras e binárias, sobrecodificadoras e nas quais opera o Estado; as moleculares, flexíveis, "de códigos e territorialidades entrelaçados"; e as linhas de fuga, que decodificam e desterritorializam (cf. idem, 2004, p. 102). As três linhas existem conjuntamente em diferentes configurações, dependendo da
} 
de um homem a um animal [...] até o imperceptível. Toda fibra é fibra de Universo. Uma fibra de enfiada de bordas constitui uma linha de fuga ou de desterritorialização" (idem, p. 33). E se uma linha de fuga apresenta perigos, riscos - da edipianização até o nazismo, quando não se conecta mais com outras linhas, transformando-se em destruição (cf. Deleuze e Guattari, 2004, p. 111-115; 2009, p. 141) - "sempre é possível se safar deles: é em cada caso que se dirá se a linha é consistente, isto é, se os heterogêneos funcionam efetivamente numa multiplicidade de simbiose, se as multiplicidades transformam-se efetivamente em devires de passagem" (idem, 2005, p. 34-35), isto é, se "suas valências" são aumentadas "a cada vez" (idem, 2004, p. 112). Ao contrário de Agamben, que toma a ideia de zona de indistinção como um lugar onde dois termos que devem se manter separados, neste caso homem e animal, se sobrepõem, criando um monstro que não pertence propriamente nem à natureza nem à lei e dando origem assim à vida nua, a zona de indiscernibilidade deleuzo-guattariana opera por uma espécie de contágio em âmbito sub-individual e de borda: "o eu é apenas um limiar, uma porta, um devir entre duas multiplicidades" (idem, p. 33). No livro sobre o pintor Francis Bacon, ao tratar de seus retratos com cabeças "sem rosto", deformadas por "traços animais" produzidos por técnicas de limpeza e escovação, Deleuze apresenta uma definição de zona de indiscernibilidade entre homem e animal:

[...] as marcas ou traços da animalidade não são formas animais, mas antes os espíritos que assombram as partes limpas, que puxam a cabeça, individualizando e qualificando a cabeça sem um rosto [...] Acontece de a cabeça humana ser substituída por uma animal; mas não é o animal como forma, é o animal como traço - por exemplo, um traço trêmulo de um pássaro que gira em torno de si sobre a parte limpa [...] Acontece de um animal, por um exemplo um cão, ser tratado como a sombra de seu mestre; ou inversamente que a sombra de um homem tome uma existência animal autônoma e indeterminada. A sombra escapa do corpo como um animal que abrigamos. No lugar de correspondências formais, o que a pintura de Bacon constitui é uma zona de indiscernibilidade, de indecidibilidade entre o homem e o animal. [...] Não é jamais uma combinação de formas, é antes o fato comum: o fato comum do homem e do animal (Deleuze, 2002, p. 27-28).

sociedade. Em relação aos centros de poder, as primeiras são sua "zona de potência”, as segundas, de indiscernibilidade e as terceiras, sua "zona de impotência" (cf. idem, p. 108); o poder age nesta zona de impotência procurando traduzir seus fluxos sobrecodificando-os em binarismos. Essas linhas compõem ainda "estados simultâneos da Máquina abstrata" (idem, p. 104) - do lado molar, seu polo sobrecodificador, onde está o aparelho de Estado; do lado das linhas de fuga, seu polo de mutação. No meio, o "tecido molecular onde mergulha" (idem, p. 108) o agenciamento operado pela máquina abstrata de sobrecodificação sobre os fluxos e quanta das linhas de fuga. 
Ainda em $O$ que é a filosofia?, Deleuze e Guattari associam o devir à invocação pela filosofia de uma "raça oprimida, bastarda, inferior, anárquica, nômade, irremediavelmente menor" (Deleuze e Guattari, 2009, p. 141) que constituiria o avesso do fascismo, o qual prega uma "raça pura" ou a terra prometida. Aquela raça e a nova terra que ela conjura, fazendo resistência ao presente, estão intimamente ligadas ao devir: trata-se do pensador diante dos animais, dos índios, dos acéfalos, de modo que se constitua o povo por vir e a nova terra. "Pensamos e escrevemos para os animais" (idem, p. 142), asseveram os autores, mas desde que esse para seja um diante de, isto é, uma questão de devir. "Tornamo-nos animal, para que o animal também se torne outra coisa" (idem). E se se devém-animal, eles advertem, não é por piedade, mas na medida em que "a agonia de um rato ou a execução de um bezerro permanecem presentes no pensamento, $[\ldots]$ como a zona de troca entre o homem e o animal, em que algo de um passa ao outro" (idem; grifo meu).

A zona de indistinção, portanto, que para Agamben é o lugar onde age o Estado de exceção, onde habita a vida nua, para Deleuze e Guattari é o meio de uma política: "Há toda uma política dos devires-animais [...] [que] se elabora em agenciamentos que não são nem os da família, nem os da religião, nem os do Estado" (idem, 2005, p. 30). O homem-lobo, mas também "os homens de toda animalidade", escapam ao Estado, à filiação, formando alianças com o fora. O tipo de devir-animal que se encontra em certos grupos africanos, eles dizem, não são da ordem de "relações simbólicas homem-animal tal como aparecem nos aparelhos de Estado" (idem, p. 24, n. 9). Talvez seja injusto com Agamben aproximar a sua zona de indistinção, onde se urde a vida nua, desse tipo de relação simbólica; mas há uma diferença fundamental entre o animal ou a animalidade tal como concebida por ele e por Deleuze e Guattari. Para o primeiro, a animalidade é um tipo de vida distinto da humanidade, cuja separação, parece, se liga à questão da posse da linguagem. No capítulo "Máquina antropológica", de O Aberto, a linguagem surge como elemento naturalcultural que marca a fronteira entre homens e animais ${ }^{12}$ e ao mesmo tempo cria a figura espúria do homem-animal. A máquina antropológica, agindo através de oposições do tipo homem/animal, acaba produzindo aí um "tipo de estado de exceção, uma zona de indeterminação" que,

12 Para um estudo sobre a relação entre humanidade, animalidade e linguagem em Agamben, cf. Fausto, 2012. 
ao separar o "animal dentro do corpo humano" (Agamben, 2007, p. 75), cria a vida nua. O homem-lobo, assim, não seria senão o muselmann, a terrível criação dos campos de concentração, "multidão anônima, continuamente renovada e sempre igual, dos não homens que marcham e se esforçam em silêncio", em quem "já se apagou [...] a centelha divina”, aos quais se hesita em chamar vivos ou mortos, cuja morte "eles já nem temem [...] esgotados demais para compreendêla", que concentram em uma imagem "todo o mal do nosso tempo [...]: um homem macilento, cabisbaixo, de ombros curvados, em cujo rosto, em cujo olhar, não se [pode] ler o menor pensamento" nas inesquecíveis palavras de Primo Levi (1988, p. 91).

Para Deleuze e Guattari, por outro lado, a tese da univocidade do ser, o fato de que "[...] o ser se diz num só e mesmo sentido em tudo o que difere" (Deleuze e Guattari, 2005, p. 39) não permite uma tal hierarquia ontológica:

O rato e o homem não são absolutamente a mesma coisa, mas o Ser se diz dos dois num só e mesmo sentido, numa língua que não é mais a das palavras, numa matéria que não é mais a das formas, numa afectibilidade que não é mais a dos sujeitos" (idem, p. 44).

Talvez a maior diferença entre esses autores, conforme mapeia o filósofo Brian Massumi, seja que no caso de Agamben a zona de indistinção é uma zona de indiferença, como se essa fosse "a única alternativa à exclusão mútua" entre homem e animal. O Aberto, assim, estaria "viciado pela recusa em considerar a possibilidade de inventar um modo de saída da lógica do terceiro excluído que não seja a indiferenciação" (Massumi, 2014, p. 111) - a ponto de apenas conseguir elaborar a inoperosidade como política possível. Já em Deleuze e Guattari, continua Massumi, as zonas de indiscernibilidade são "o cadinho da emergência do novo" e operam sob a lógica do terceiro incluído, ou melhor, de uma "inclusão mútua": "longe de serem zonas de indiferença que absorvem e desativam a atividade, elas são apetitivamente transbordantes de atividade [...] A lógica da inclusão mútua é a lógica da diferenciação: o processo de proliferação contínua de emergências diferentes” (Massumi, 2014, p 49-50). Assim, a zona de indistinção na qual se dá o devir não é o lugar da produção do muselmann; pelo contrário, tornar-se judeu, por exemplo, é uma saída criadora para não se tornar nazista Deleuze e Guattari, ao afirmarem, sobre o romance $O$ intruso, de Faulkner, que "não havia outra escolha senão devir-negro para não acabar fascista", remetem em 
nota a um comentário do próprio escritor sobre o lugar dos brancos depois da Guerra de Secessão norte-americana: "Faulkner escreve: 'Estamos na situação do alemão após 1933, que não tinha outra alternativa senão a de ser nazista ou judeu" (idem, p. 89). Essa "saída" de que os autores falam tem por sua vez uma origem animal: é a expressão usada por Rotpeter, o ex-macaco narrador de "Um relatório para uma Academia", de Kafka: "Não, liberdade eu não queria. Apenas uma saída" (Kafka, 1994, p. 61). Deleuze e Guattari glosam: "Não se trata de liberdade por oposição à submissão, mas somente de uma linha de fuga, ou antes de uma simples saída" (Deleuze e Guattari, 1975, p. 13). Poder-se-ia levantar a hipótese de que a saída é ela mesma uma categoria da política animal ou da política do devir-animal.

Ainda, para Deleuze, inspirado por Spinoza, os animais - incluso aí o animal humano - são antes corpos que espécies biológicas, e esses corpos são conjunto de afetos - "[d]aquilo que podem, [dos] afetos dos quais são capazes, tanto na paixão quanto na ação" (cf. Deleuze e Parnet, 1998, p. 49-50). É por isso que se pode dizer que "há mais diferença entre um cavalo de corrida e um cavalo de trabalho do que entre um cavalo de trabalho e um boi” (idem).

Foi inspirada por esta afirmação de Deleuze que imaginei se não seria possível "profanar" o conceito de vida nua de Agamben e empregá-lo em relação aos animais. Como Farage, acreditava que a vida dos animais, de muitos animais, era por demais assemelhada à vida nua, esta que se mantém nas bordas da política, sendo excluída mas imediatamente capturada por ela, e sobre a qual o poder soberano se exerce de maneira terrível. Isso seria uma torção do conceito, pois suporia um deslocamento da ideia de zona de indistinção. Escrevi então um e-mail ao próprio Agamben, na tentativa de verificar a possibilidade de uma vida política dos animais e sua relação com o Estado. A troca se deu assim:

JF: [...] há algo que realmente me intriga: há uma vida nua dos animais? Ou a vida nua é um conceito que apenas se aplica a humanos? Penso, por exemplo, na diferença entre cavalos selvagens e cavalos de carroça, ou na diferença entre elefantes livres e elefantes de circo; estes últimos devem ser "quebrados" antes de serem colocados para trabalhar. [...]

GA: [...] Obrigado por sua mensagem. A vida nua é algo produzido pelo poder e, na sua perspectiva, deveríamos pensar em uma ação do poder sobre os animais, o que é talvez concebível. Mas não existe uma vida política dos animais, então, nesse sentido, a vida nua não parece possível para eles. [...] (Comunicação pessoal por email, datada de 12/05/2013. Tradução minha). 
Tal resposta foi como um balde de água fria. Talvez, se não tivesse escrito, insistido na pergunta, poderia ter feito uso do conceito com bons resultados, como Farage. E mesmo depois da troca de e-mails, poderia ter mantido esse uso, apesar do autor, explicando as suas e as minhas limitações e questões, articulando um acesso possível. Teria sido um método válido, acredito. Mas preferi não fazê-lo. O que essa troca deixou claro, como em um golpe, foi a recusa absoluta, mesmo por parte de um autor contemporâneo e considerado sensível ao modo como a política, a biopolítica, se exerce sobre populações minoritárias, à existência política dos animais. Essa correspondência aconteceu em maio de 2013, quatro meses depois de Bruxo e Nausicaa terem vindo morar comigo, oito meses antes da chegada de Batatinha. Agamben me barrava, ou melhor, nos barrava, naquelas poucas linhas, ao dizer "mas não existe vida política dos animais", não existe uma relação política. Afetiva, provavelmente, mas não política.

Talvez, pensei, ele estivesse certo, e toda a minha imaginação acerca dos gatos que vivem comigo como refugiados políticos ou da gata-mãe de Bruxo e Nausicaa como desaparecida forçada fosse um grande delírio. Talvez o poder pudesse apenas se exercer sobre eles - na minha perspectiva, como lembrava Agamben -, sem que eles mesmos experimentassem uma vida política. Então a biopolítica estatal de que falava Farage, ao criar categorias como animal errante e peste, poderia de fato agir sobre os animais sem que eles, por sua vez, vivessem politicamente. Os cavalos e o boi de Deleuze, separados por um poder que permite que algumas potências e afetos se desenvolvam ou não, também não estariam implicados em nenhuma política. Os elefantes de circo envolvidos nos processos pelos quais são "amansados", com surras constantes enquanto contidos por correntes, seriam afetados pelo poder. Agamben concedia pelo menos isso, mas algo em sua conformação, em seu corpo talvez, certamente alguma falta originária, não permitia que eles participassem da política. Parte constituinte de nossa sociedade, seja como indesejados expulsos e exterminados nos processos de higienização, ou como cobaias e matéria-prima para a indústria farmacêutica e de cosméticos, como puxadores de veículos, como auxiliares da polícia, como terapeutas em hospitais, como ajudantes de pessoas com deficiência, como atores na indústria do entretenimento, como alimento de populações ou mesmo como companheiros, os animais existiriam aí como meros objetos, pobres coitados que 
alguém como eu consideraria como pacientes do poder, mas jamais como sujeitos ou agentes políticos.

\section{5.}

\section{Amizade e pastoreio}

Volto a olhar para os gatos que vivem comigo, Bruxo, Nausicaa e Batatinha, para sua vida restrita em nosso apartamento. Penso nas causas dessa restrição. No alimento que recebem aqui, produzido por uma multinacional especializada em pets. Em seus corpos atléticos e mutilados - castrados. Na quantidade de pelo que cai desses corpos e fez mudar o regime de limpeza da casa. No problema que experimentam amigos alérgicos, que não podem passar muito tempo aqui. Nos cigarros que procuramos acender longe deles - já há animais demais como cobaias de experimentos realizados pela indústria do tabaco - e em seus protestos ao serem retirados de algum dos cômodos, protestos por vezes bem sucedidos, fazendo-nos mudar de ideia e deixar que ali permaneçam. Na relação que travam os gatos entre si, comigo e com meu companheiro. Nas suas e nossas preferências. Nos rituais que criamos juntos, no repertório de gestos que aprendi, ensinei e coinventei. Na economia de afetos, ciúme, raiva, ternura. No modo como me interpelam. Nos limites que cada um de nós encontra diante do corpo e da vontade dos outros. Volto meus olhos mais uma vez para o apartamento no qual vivemos, penso nos espaços que instauramos à base de negociações assimétricas.

Haraway lembra que "companheiro vem do latim cum panis, 'com pão'. Comensais à mesa são companheiros. Camaradas são companheiros políticos" (Haraway, 2008, p. 17). Estaria ela se contrapondo aqui propositalmente a Aristóteles, que, na Ética a Nicômaco, nega que, no caso dos homens, viver junto (syzaō) seja comer no mesmo lugar, como no caso do gado (cf. Aristóteles, 1894, 1170b)? Comensalidade, responderia Aristóteles a Haraway, não constitui comunidade ou companheirismo entre humanos - é possível mesmo que o filósofo jamais tenha imaginado a estranha possibilidade de uma comunidade multiespecífica. Para ele, viver junto entre homens diz respeito à amizade específica; um pouco antes, na mesma passagem, o filósofo afirma que todas as nossas ações são acompanhadas por um sentir (aisthánomai, idem, 1170a): sentese que se vê ao ver, sente-se que se pensa ao pensar, em suma, "ser é sentir e 


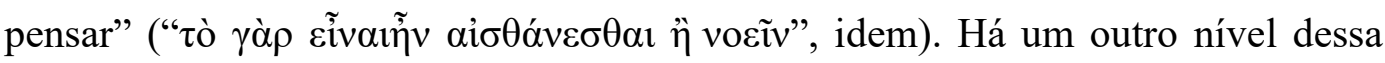
sensação ou percepção, entretanto, aquele em que se experimenta junto, a saber, sentir junto ou com-sentir (synaisthánomai), algo que passa pela amizade: “também para o amigo se deverá com-sentir que ele é e isso vem a ser no viver

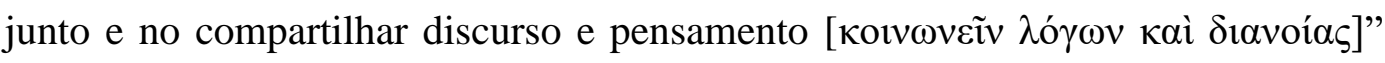
(idem, 1170b). Em outras palavras, sente-se o amigo em si ao conversar e pensar conjuntamente e é isto que constitui o viver junto humano. É nesse sentido, continua Aristóteles, que os homens convivem, diferentemente do gado, para quem basta comer do mesmo pasto. Agamben, no ensaio "O amigo", debruça-se sobre esse mesmo trecho - é dele a tradução de synaisthánomai como com-sentir - para apontar aí uma "base ontológica" (Agamben, 2009, p. 86) da amizade; exclusivamente humana, ela consistiria como que numa extensão da sensação de ser, a de com-sentir que o amigo é. Sentir ser diria respeito sempre a mais que um e, seria, assim, dividido: "o ser mesmo é [...] não idêntico a si, e o eu e o amigo são as duas faces - ou polos - dessa com-divisão" (idem, p. 89). Daí se segue, para Agamben, que "a amizade tem um estatuto ontológico e ao mesmo tempo político" (idem, p. 89), que ele encontra justamente na diferenciação feita entre homens e gado - os amigos humanos são eles mesmos "condivididos" (idem, p. 92), não dividem algo, o pasto. A originariedade da condivisão é ela mesma o nascimento da política: "aquilo que há para repartir é o próprio fato de existir [de ser], a própria vida" (idem). Um companheiro, assim, não dividiria o pão, como pensa Haraway, mas o próprio ser, possibilidade unicamente humana que está, no texto aristotélico, relacionada com o discurso e o pensamento, pois é por esse meio que vem a ser. Agamben, assim, através de Aristóteles, de uma só tacada impede a amizade multiespecífica e barra ontologicamente os animais da política.

Há ainda uma outra questão que emerge dessa interpretação, a do privilégio ontológico da amizade na filosofia e na política, que se tornam um affair entre amigos. Na mesma passagem comentada, Aristóteles diz que o amigo é um “outro

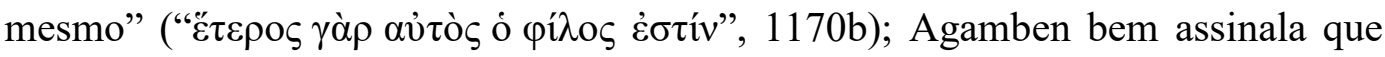
há uma histórica confusão acerca do entendimento deste héteros autós, muitas vezes traduzido como segundo eu ou alter ego, o que abriu caminhos distintos daqueles contidos no texto original. Héteros, ele lembra, é uma palavra que significa diferente em um contexto binário (por exemplo, quando se diz, em grego, “a outra mão" para designar a mão esquerda), ao contrário de állos, que 
quer dizer qualquer outro. $\mathrm{O}$ amigo, então, como héteros autós é uma espécie de parte constitutiva ou ligada ao mesmo (eu), aquele a partir de quem o mesmo é. A filosofia, que traz o amigo em seu próprio nome, como gosta de lembrar Agamben, e a "sinestesia política originária" (Agamben, 2009, p. 92) que vem ao mundo pelo com-sentir de um outro mesmo em mim, excluiriam assim todos os "quaisquer outros" - tudo aquilo que, para Agamben e talvez para Aristóteles, constituem inimigos ou outros não binários. Não são só os animais que estariam fora da política, mas todos os outros fora de relações de par, todos os que não são meus amigos. Isto é, para Agamben, pode haver política entre amigos em Atenas; mas e a relação com as outras cidades? Seria barbárie, administração, economia? Por outro lado, o que se tornaria a filosofia diante dos outros?

Deleuze e Guattari respondem a uma pergunta parecida em $O$ que é a filosofia?:

O não-filosófico está talvez mais no coração da filosofia que a própria filosofia, e significa que a filosofia não pode contentar-se em ser compreendida somente de maneira filosófica ou conceitual, mas que ela se endereça também, em sua essência, aos não-filósofos (Deleuze e Guattari, 2009, p. 56-57).

Para os autores, a filosofia diz respeito, e mais que isso, fala a não-amigos (nãofilósofos): "A filosofia precisa de uma não-filosofia que a compreenda, ela precisa de uma compreensão não-filosófica” (idem, p. 278). Essa não-filosofia, para usar o vocabulário grego, é da ordem de um állos, não de um heteros, "não [...] de seu negativo como começo, nem como fim no qual seriam chamadas a desaparecer realizando-se, mas em cada instante de seu devir ou de seu desenvolvimento" (idem). Não se trata, pois, de um negativo, de um par natural ou de um "outro mesmo" mas, sendo da ordem do devir, "da intrusão de um fora" (Zourabichvili, 1997, p. 2), como o filósofo François Zourabichvili explica o encontro disparado por um outro outro. Ele vai ainda além ao dizer que só se encontra em sentido forte o que não se é, ou seja, o não-humano (cf. idem) e usa uma fórmula parecida com a aristotélica, mas com termos diferentes, para explicar o movimento muito diverso daquele que constituiu o viver junto humano, o do devir-animal deleuzoguattariano: "sentir como sentimos que [o animal] sente, [...] senti-lo sentir em nós” (idem, p. 9). Uma tal possibilidade, a de talvez com-sentir com um animal, não é sequer pressentida por Agamben em sua interpretação de Aristóteles. Há uma divergência fundamental, portanto, entre Agamben e Deleuze e Guattari, que repousa sobre a própria ideia do que constitui a filosofia. Ação entre amigos ou 
relação constante com o fora? Mais uma vez, o conceito de devir abre uma promessa de relação que não encerra a política nos confins da humanidade - ou de sua amizade. Não parece mais tão impossível que comensais, companheiros ou inimigos possam conviver filosófica e/ou politicamente.

Retornando a Agamben e sua aliança com Aristóteles, com quem o italiano trava uma espécie de amizade atávica, fica claro que o primeiro não fazia uma afirmação original ao dizer que não há vida política dos animais. Na verdade, ele apenas se inscrevia numa longa linhagem, majoritária, da história da filosofia. Sua recusa encontrava mais uma vez o grego, desta vez em uma célebre passagem da Política, quando este associava política e linguagem para, ao recusar a segunda aos animais, conferir um excedente da primeira aos homens ${ }^{13}$ :

É óbvio por que o homem é um animal político em maior medida que qualquer

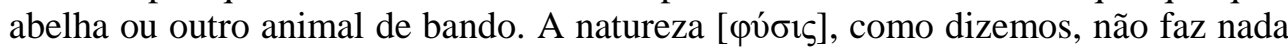

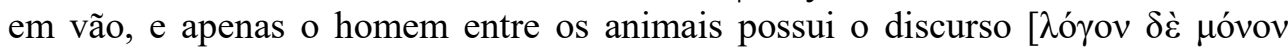

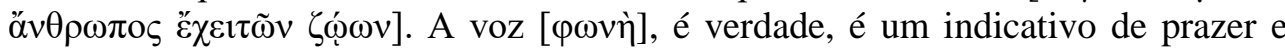
dor, e é por isso que os outros animais também a possuem; pois a natureza destes se estende até aí, ter sensações de prazer e dor e indicá-las uns aos outros. O discurso, por outro lado, serve para deixar claro o que é benéfico e o que é prejudicial, e assim também o que é justo e o que é injusto. Pois por contraste com os outros animais o homem tem esse próprio: somente ele tem o sentido de bem e mal, justo e injusto etc. Uma comunidade nestes assuntos faz uma casa e uma

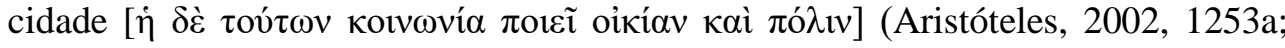
tradução modificada).

Antes de Aristóteles ainda, podemos encontrar em Platão uma pista sobre essa repulsa. Na República, quando Sócrates narra a seus companheiros como os modos de governo decaem uns em direção aos outros até chegarem à democracia, maldiz um suposto excesso de liberdade encontrada nesta. Em uma cidade democrática, ele explica, imigrantes e estrangeiros são como cidadãos, homens e mulheres se igualam, escravos tornam-se não menos livres que seus donos e, horror dos horrores, os animais se liberam do jugo humano:

os bichos mesmos que são de uso dos homens são aqui muito mais livres que alhures [...] É de fato aí que as cadelas, como diz o provérbio, se parecem com suas donas; é aí que se veem cavalos e asnos, acostumados a um aspecto livre e altivo

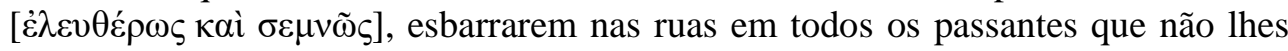
cedem o passo; e é em tudo o mesmo, um transbordamento de liberdade (Platão, $1967,563 \mathrm{c})$

${ }^{13} \mathrm{O}$ homem não é o único animal político para Aristóteles, embora seja aquele que, por uma relação com o lógos, o é mais propriamente ou de modo mais pujante. Para outros animais políticos, cf. Aristóteles, 1837. Para uma discussão sobre a diferença do caráter político humano e de outros animais, cf. Depew, 1995. 
A liberdade desenfreada da cidade democrática pavimenta um caminho que torna necessário o surgimento da tirania depois dela; ela assenta um "temperamento anárquico" por todo canto, desde os lares [oỉkíaı] até os animais

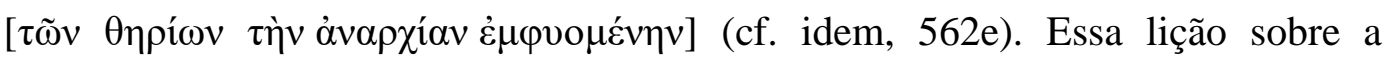
anarquia é retomada ainda nas Leis, um diálogo de velhice, desta vez pela boca do ateniense, quando este afirma que ela "deve ser completamente removida da vida de todos os homens e dos bichos a eles sujeitados" (Platão, 1976, 942d). Para evitar que a anarquia se instale no corpo social, a República oferece como princípio fundador da cidade a boa divisão do trabalho: é de suma importância que cada um habite seu lugar devido, visto que ninguém nasce igual a ninguém. A cada natureza, phýsis, corresponde uma atividade, érgon (cf. Platão, 1967, 370b), e é dessa diferença e por ela que a cidade nasce e se mantém. A liberdade "transbordante" da democracia deve ser portanto evitada de todos os modos; ela pode destruir a diferença fundadora, além de levar inevitavelmente à tirania, o pior de todos os governos. E o tirano, na retórica socrática, é alguém que nasce de dentro do povo espoliado, um favorito do povo que, "por provar carne humana",

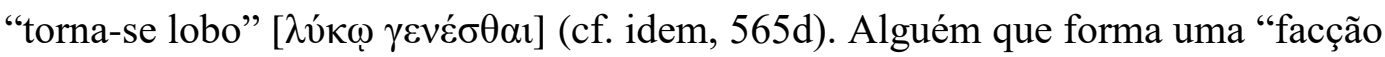
contra os possuidores de propriedades" (idem, 566a), o tirano deixa de ser homem para se tornar animal; sua gênese é assim descrita por Sócrates:

Quando um líder do povo, tendo capturado a persuasão da multidão, não consegue se abster do sangue de seus parentes; quando, por costumeiras acusações injustas, leva ao tribunal e assassina, suprimindo a vida de um homem, e com uma língua e uma boca ímpias que provam o sangue de parentes, exila e mata, insinuando a redução das dívidas e uma nova partilha da terra, não é por conseguinte para um tal uma necessidade e um destino ou morrer na mão de seus inimigos ou tornar-se

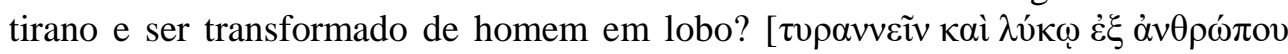
$\gamma \varepsilon v \varepsilon ́ \sigma \theta \alpha 1]$ (idem, 565e-566a).

O lobo antropófago é a figura oposta do filósofo, tão divino quanto pode ser um homem, e rei no melhor dos governos possíveis, a aristocracia (cf. Platão, 1894, 445d, 473c, 500d). Entre um e outro interpõem-se os cães, a quem são comparados, por seu temperamento, os guardiães e auxiliares da cidade: "os auxiliares são como cães sujeitos aos governantes, que são como pastores da cidade" (idem, 440d). O pior que pode acontecer a eles é que se assemelhem a lobos, diz Sócrates, e ataquem o gado (idem, 416a) - a quem, obviamente, corresponde o povo. Há todo um bestiário na República que marca diferenças de tipo e instaura modelos de interação. É como se as relações na pólis já pudessem 
ser entrevistas em relações multiespecíficas, sendo o modelo mesmo do bom governo aquele do pastoreio: trata-se de um ou mais pastores (poucos) auxiliados por cães (alguns mais) protegendo seu gado (muitos) de lobos selvagens e violentos (número indeterminado). Mas a coisa não é tão simples como parece: não só o cão corre sempre o risco de voltar a se tornar lobo, já que há entre ambos uma continuidade, mas o pior de todos os lobos, o antropófago, é uma transformação do gado - quando as ovelhas, por exemplo, elegem uma favorita, quando uma delas se rebela diante do pastor e acena para uma nova partilha, desmontando a ordem estabelecida. Esta ovelha, segundo Sócrates, provaria necessariamente o sangue dos seus por acusações injustas e, por ser canibal, tornar-se-ia assim um lobo, como no mito de Licáon, mencionado linhas antes, no qual o rei é transformado em lobo por Zeus depois de lhe ter oferecido carne humana ${ }^{14}$. Ainda mais: se cada uma dessas espécies corresponde a um tipo de homem, qual o lugar do pastor, que já é homem, o governante, na cidade real?

Uma resposta possível passa pelo fato de que Platão não pensava em termos de espécies como nossa biologia atual; mas é preciso ir um pouco mais fundo: a este homem que já é anthropos na imagem animal da cidade corresponde um homem quase divino na cidade atual (ou na cidade de lógos). É como se o governante possuísse um excesso de humanidade que o aproxima dos deuses e lhe permite controlar as modificações dos lobos - lobos-fieis/cães, lobosmansos/ovelhas -, evitando o surgimento do lobo antropófago. No limite, se essa hipótese tem algum sentido, só há para Platão dois tipos principais: pastores e lobos metamorfos. A divisão política fundamental se assentaria na diferença de tipo entre humanidade e animalidade, lembrando ainda uma vez que a anarquia "deve ser completamente removida da vida de todos os homens e dos bichos a eles sujeitados.” É possível compreender, nesse sentido, que a consequência mais perturbadora da liberdade democrática seja referente aos animais, pois é a diferença entre animais e homens, na medida em que os primeiros estão subjugados aos segundos, o fundamento da politéia.

${ }^{14} \mathrm{O}$ mito é narrado por diversas fontes; Pausânias, por exemplo, menciona uma crença segundo a qual, após Licáon, alguém transformado em lobo, caso se abstivesse de carne humana por nove anos, retornaria a ser homem (cf. Pausanias, 2002, p. 18). Ovídio conta o momento da metamorfose, do ponto de vista de Zeus: "Ele [Licaón] foge e, aterrado, em campo silencioso,/ ulula, em vão tentando falar; ele próprio/ recolhe a raiva à boca e ávido de mortes/ volta-se contra o gado e em sangue se compraz/ A veste se converte em pelo e braço em perna;/ faz-se lobo e conserva algo da antiga forma:/ as mesmas cãs, o mesmo rosto violento,/ o mesmo olhar brilhante e um furor idêntico" (Ovídio traduzido por Carvalho, 2010, p. 46). 
Aristóteles é ainda mais duro quando explicitamente compara certos animais a escravos por seu "uso". Na Política, depois de postular, sobre o escravo "por natureza", que ele "compartilha do lógos a ponto de apreendê-lo, mas não de tê-lo

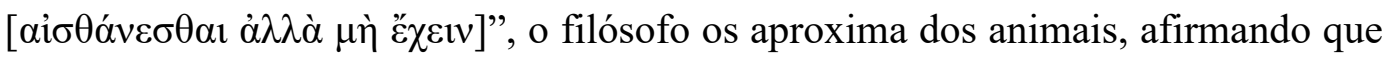
"o uso feito de ambos difere pouco; pois de ambos - escravos e animais domesticados - vem ajuda corporal no fornecimento de necessidades" (Aristóteles, 2002, 1254b20-25). Vale ainda pensar essa comparação e o lugar de animais e escravos na casa e na cidade em sua relação com a ideia aristotélica que abre a Política, a saber, que a diferença entre o governante e o chefe de família é de tipo e não de tamanho (1252a7-10), isto é, que política e oikonomía não se confundem. A pólis seria anterior - não historicamente, mas por natureza - ao oikos, "pois o todo deve ser anterior à parte" (idem, 1253a20). Desse modo, os animais domésticos e os escravos, ambos por uma falta por natureza, fazem parte da casa mas não da cidade - o todo não vale para todos - isto é, não existem politicamente. A maior parte dos animais criados na Grécia à época de Aristóteles, ovelhas e bodes os mais comuns, mas também galinhas, bois, porcos, mulas, asnos e cavalos, são considerados pelo filósofo como animais de bando, comensais entre si mas não políticos. As abelhas, por sua vez, possuem aquele caráter político que, na História dos Animais, era definido por uma "atividade

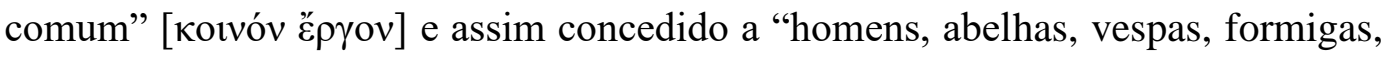
grous" (cf. Aristóteles, 1837, 488a). Embora Aristóteles dedique muitas páginas às partes, modos de vida, reprodução e relação dos e entre os animais, inclusive reconhecendo em alguns deles "uma certa phronesis [...], comunicação mútua, ensinamento e aprendizado (com outros animais ou com homens), cuidado e a faculdade de antecipação (EN 1141a26-28, HA 536b17-18, 608a14-19, GA 753a8ff, PA 660a35-b2)" (Aristóteles, 2002, p. 70), não encontrei nesta pesquisa nenhuma passagem em que o filósofo se tenha dedicado a pensar que tipo de diferenças poderiam emergir de relações multiespecíficas. Os animais domésticos, afinal, vivem junto dos homens e trabalham para (ou com) estes; será que não passariam assim a realizar uma atividade comum? Será que não estariam sendo governados por um chefe humano? Ou essas relações multiespecíficas seriam todas estritamente econômicas e incapazes de modificar os termos contidos nelas? Se for assim, então os animais domésticos, que, pelo uso feito de seu corpo, ajudavam no "fornecimento de necessidades", apenas perambulavam como 
espécies de ferramentas dotadas de alma sensível na cidade aristotélica. Há ainda uma outra questão: mesmo que a política seja anterior, por natureza, à economia, não seria aquela sempre sobredeterminada por esta, com suas divisões, relações e hierarquias? Em outras palavras: pode a política se reivindicar diferente em tipo da economia se aqueles a quem se concede ou não participarem dela têm seus estatutos estabelecidos economicamente? Ou ainda, quando constituem as próprias condições materiais de possibilidade - é somente por meio do trabalho do escravo e do animal, por exemplo - do exercício da política?

Seja como for, para Aristóteles a associação entre animais e escravos é clara; ele afirma que "o boi é o escravo doméstico do pobre [ó yò $\rho$

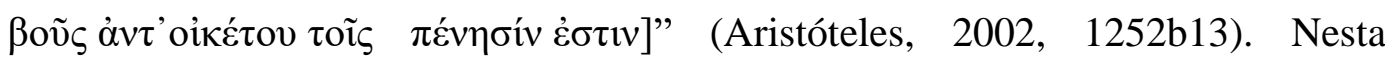
comparação é importante notar que, ao aproximar os animais dos escravos, Aristóteles está aproximando os escravos dos animais, no que se poderia entender como um tipo de zona de indistinção agambeniana. Ambos se encontrariam ali onde são deficientes de lógos, uns por não possuí-lo, embora o apreendam, os outros por estarem totalmente fora dele. Isto é, a relação com o lógos não apenas separa dois mundos, o da política mais alta e o "natural" (cuja política, se há, não está no mesmo nível da outra), mas determina, dentro do ordenamento da pólis, o lugar de cada um. O problema não é, portanto, simplesmente estar excluído da política, mas o modo como se é imediatamente capturado por ela.

\section{6.}

\section{Razão do mestre versus saberes situados}

Em Jamais fomos modernos, Bruno Latour, após expor a querela entre Hobbes e Boyle no século XVII como fundadora daquilo que ele chama de “Constituição Moderna”, explicita esta última nos seguintes termos:

Cabe à ciência a representação dos não-humanos, mas lhe é proibida qualquer possibilidade de apelo à política; cabe à política a representação dos cidadãos, mas lhe é proibida qualquer relação com os não-humanos produzidos e mobilizados pela ciência e pela tecnologia (Latour, 1994, p. 33-34).

Isto é, de acordo com a Modernidade tal como descrita por Latour, Agamben tinha razão: não existe vida política dos animais. Nesta Constituição, duas casas distintas, a da Natureza e a da Sociedade, não podem se comunicar. A uma está ligada a verdade, mas ela é muda; a outra, a do "falatório", não pode 
produzir verdade alguma. Os animais não-humanos residiriam, claro, na primeira. São mudos, obedecem a leis físicas e estão completamente apartados da política, matéria exclusivamente humana. Agamben teria assim apenas enunciado este princípio basilar da modernidade. ${ }^{15}$

Em Políticas da natureza, volume lançado oito anos mais tarde, em 1999, Latour recua ainda mais, situando a origem dessa divisão no mito da caverna da República. Neste mito haveria, além da separação entre duas casas, uma segunda mudança de eixo que influenciou todo o ocidente: não apenas o filósofo - e, depois, o cientista - tem a prerrogativa de sair de dentro da caverna para acessar a verdade, como em seguida precisa retornar para "silenciar o falatório interminável da multidão ignorante" (Latour, 2004, p. 11). Na narrativa é desenhada uma imagem do mundo na qual ele se divide em dois domínios, o humano e o natural, além de um modo de operação: embora não haja contiguidade entre os dois, é dado ao filósofo/cientista o privilégio não de habitá-los ao mesmo tempo, mas de, a partir do lógos, conhecer o segundo domínio - e usar esse conhecimento para ordenar o primeiro. Para Latour, os chamados pós-modernos, muito longe de superar a modernidade, apenas levariam o projeto moderno a cabo: ao posicionar de uma vez por todas "o mundo material e a técnica de um lado, os jogos de

${ }^{15}$ Latour, ao descrever sua Constituição Moderna, aproxima-se do filósofo Alfred North Whitehead e seu conceito de "bifurcação da natureza." Em O conceito de natureza, Whitehead critica a tendência moderna de dividi-la em qualidades primárias e secundárias: "o alvo de meu protesto é essencialmente a bifurcação da natureza em dois sistemas de realidade, os quais, conquanto sejam reais, são reais em sentidos diferentes. Uma realidade seriam as entidades como os elétrons, objeto de estudo da física especulativa. Essa seria a realidade oferecida ao conhecimento, muito embora nessa teoria ela jamais seja conhecida. Isso porque o passível de cognição é a outra espécie de realidade, a ação coadjuvante da mente. Existiriam, portanto, duas naturezas: uma é a conjetura e a outra, o sonho" (Whitehead, p. 38). Segundo ele, ainda, "para a filosofia natural, tudo quanto é percebido encontra-se na natureza [...] Para nós, o fulgor avermelhado do poente deve ser parte tão integrante da natureza quanto o são as moléculas e ondas elétricas por intermédio das quais os homens da ciência explicariam o fenômeno" (idem, p. 37). Em seu livro sobre o filósofo, Isabelle Stengers nota que é imperativo para ele, de modo a evitar a bifurcação, estabelecer uma pluralidade não hierárquica de objetos: objetos sensíveis ("o som, a cor, o odor" Stengers, 2002, p. 102), científicos ("em princípio" "aquelas moléculas cujo comportamento de conjunto explica a propagação disso que percebemos como som", idem) e perceptivos ("este pássaro que canta ali, sobre seu galho", idem). Ela então explica que "afirmar ao mesmo tempo os objetos 'sensíveis', 'perceptivos' e 'científicos' é recusar todo princípio de classificação. Este pássaro, eu sei que é ele que canta: isso de que tenho a experiência não se declara somente uma sucessão de sons mais 'canto', e esse canto é produzido por um ser vivo, não por um corpo material vibrante, e esse ser habita, ele também, o mundo onde eu estou, eu o percebo enquanto declaro que não estou só. Eu faço parte do mundo desse ser, como ele faz parte do meu. Não se engana o poeta que celebra o canto do pássaro e o mundo que esse canto celebra. E o etólogo testemunha contra a bifurcação da natureza quando confia em sua experiência e procura exibir a significação do canto para o pássaro, chamado à sua fêmea, anúncio territorial, "esta é minha árvore"” (idem, p. 102-103). 
linguagem dos sujeitos falantes de outro" (idem, 1994, p. 61), eles criariam então uma "hiper-incomensurabilidade" (idem) capaz de neutralizar qualquer tensão ou passagem entre esses dois mundos.

A filósofa ecofeminista Val Plumwood usa o mesmo prefixo em Feminism and the Mastery of Nature ao falar em uma "hiperseparação" requerida pelos dualismos que, segundo ela, "formaram tanto a paisagem política ocidental moderna quanto a antiga" (Plumwood, 1993, p. 3). Sua análise do conceito de dualismo dentro do mundo ocidental pode tornar a questão do lugar dos animais na política mais visível. Um dualismo, Plumwood explica, não pode ser confundido com uma simples dicotomia, pois o que ele cria é uma diferença hierárquica: para a filósofa, o ocidente se constituiu segundo uma "lógica do mestre", que "inferioriza" os termos que lhe são subordinados "tanto individual quanto culturalmente, os põe em segundo plano e desvaloriza suas obras, e os define como a periferia do centro do mestre" (idem, p. 63), que pode ser condensada no dualismo razão/natureza como uma perspectiva do poder. A partir desse dualismo seria possível encontrar outros, derivados ou conectados a ele como "postulados de ligação", "suposições normalmente feitas ou implícitas no pano de fundo cultural que criam equivalências ou um mapeamento entre os pares" (idem, p. 45). Ela explicita:

Por exemplo, o postulado de que todos os humanos e apenas eles possuem cultura cartografa o par cultura/natureza no par humano/natureza; o postulado de que a esfera da razão é masculina cartografa o par razão/corpo no par macho/fêmea; e a suposição de que a esfera do humano coincide com aquela do intelecto ou mentalidade cartografa o par mente/corpo no par humano/natureza e, via transitividade, o par humano/natureza no par macho/fêmea. [...] O contraste civilizado/primitivo cartografa todos os contrastes humano/animal, mente/corpo, liberdade/necessidade e sujeito/objeto (idem).

A razão, ao se opor, se separar e se elevar acima da natureza, seria assim o ator fundamental, o mestre primevo que organizaria o mundo em pares segundo uma lógica de "dependência denegada de um outro subordinado" (idem, p. 41). O problema dos dualismos não adviria portanto do pressuposto de diferenças entre os termos, mas do movimento que, ao hiper-separá-los, denega relações mútuas de dependência, instaurando uma hierarquia imutável de tipo "dominação/subordinação [que] molda a identidade de ambos os relata" (idem).

Plumwood elenca uma série de aspectos da estrutura lógica do dualismo: 1 . “o backgrounding (denegação)”, a recusa da importância da atividade do termo 
inferior, ainda que esta seja essencial à manutenção do superior, por meio do direcionamento da perspectiva, de modo que essa atividade apareça como mero pano de fundo; 2. "a exclusão radical (hiperseparação)", a escolha e extrapolação de diferenças entre os termos para que elas se construam como de tipo e não de grau, resultando em uma polarização incomensurável; 3. "a incorporação (definição relacional)", a premissa de que o termo superior é o padrão e o inferior se define por falta ou negatividade diante dele; 4. "o instrumentalismo (objetificação)", a ideia de que o termo superior é um fim em si mesmo e o inferior é um recurso, um meio, seus fins sendo os fins do termo superior; e 5. "a homogeneização ou estereotipificação", a indiferenciação de todos os membros do termo inferior entre si. É importante observar que o dualismo não cria diferenças onde elas não existem, mas opera exacerbando-as e interpretando-as de modo a fixar uma única perspectiva: “O dualismo impõe um quadro que polariza e cinde em duas ordens de ser aquilo que pode ser conceitualizado e tratado de modos mais integrados e unificados" (idem, p. 55).

A razão soberana, "super-herói ${ }^{16}$ protagonista da psiquê ocidental" (idem, p. 3), vem sendo convocada desde a antiguidade para produzir e fazer a manutenção de mundos assentados na lógica dualista; o que Plumwood sugere é o desvelamento da política por trás dessa lógica, a política da lógica do mestre. Isso não significa, e ela é inflexível a esse respeito, um abandono puro e simples da razão, mas sua "redefinição ou reconstrução em modos menos oposicionais e hierárquicos" (idem, p. 4). No segundo capítulo de Feminism and the Mastery of Nature, essa proposta é feita na forma de uma crítica às lógicas clássicas, segundo a autora, lógicas em que o sujeito é o mestre. Contra a negação como "um conceito específico [...] que nos força a considerar a alteridade em termos de um universo único consistindo de tudo" (idem, p. 56), ela lança mão de outros sistemas lógicos, não clássicos, como o da relevância, "que pode ser interpretado como exprimindo uma noção de alteridade enquanto diferença não-hierárquica" (idem, p. 58). O problema com a lógica clássica, segundo Plumwood, é sua "estrutura dualística" (idem, p. 56) e aquilo que se supõe natural nela nada mais é que o sistema de dominação que ela espelha.

\footnotetext{
${ }^{16}$ Apesar de o substantivo razão ser feminino em português, mantive o termo masculino super-herói, para seguir o pensamento de Plumwood (cf. Plumwood, 1994).
} 
$\mathrm{Na}$ negação clássica esse caráter se torna evidente, por exemplo, quando visto em um diagrama Venn "representando p como uma figura rodeada por um quadrado que representa o universo, com $\sim p$ como o restante" (idem), tornando $\sim p$ impossível de ser identificado "independente ou positivamente" (idem); p é assim subordinado a p, sem "um papel independente", "meramente estrangeiro à noção primária p" (idem). Sem peso existencial próprio, $\sim$ p está sempre em relação a p, presente ou ausente segundo condições estabelecidas por p, ou seja, consistindo em um dualismo que o incorpora e homogeneíza: "o outro de p, como um receptáculo, é indistinguível do resto do universo" (idem, p. 57). A negação entendida como colapso procura manter p e $\sim$ p a uma distância total um do outro em uma hiperseparação sob pena de o sistema inteiro cair, no que se chama, entre outros, princípio de explosão ou ex quodlibet: da afirmação de uma contradição qualquer coisa pode ser inferida $(\mathrm{p} \wedge \sim \mathrm{p} \rightarrow \mathrm{q})$. Toda tentativa de aproximação, "mesmo em pensamento", lembra Plumwood, "leva à pior penalidade de um sistema lógico, o colapso do sistema" através da "perda de todos os limites" (idem).

Finalmente, na possibilidade da supressão, isto é, na existência de uma premissa que não precisa ser enunciada, encontra-se o mecanismo pelo qual a lógica clássica opera um backgrounding - "no qual se depende da contribuição do outro para o resultado mas esta contribuição é denegada ou ignorada" (idem, p. 58). Sobre a "supressão da verdade", Plumwood ainda nota que ela

está intimamente relacionada à outra característica da lógica clássica, a permutabilidade de verdades, na qual qualquer verdade pode ser substituída por qualquer outra verdade enquanto preservar propriedades de implicação. Está também relacionada à característica de que a equivalência material como critério de identidade preposicional produz apenas uma verdade e uma proposição falsa. Essa permutabilidade de verdades pode ser vista de modo alternativo como indicando que uma implicação material exprime um raciocínio instrumental ou dirigido a um fim, no qual condições como meios são intercambiáveis desde que elas produzam efeitos ou fins equivalentes (idem, grifo meu).

Em lógicas não-clássicas, por outro lado, encontram-se sistemas nos quais a negação e a alteridade são entendidos diversamente. Na negação relevante, por exemplo, $\sim \mathrm{A}$ não é homogeneizado e sua aproximação com A "não induz ao colapso do sistema" (idem, p. 58) pois nela "a exclusão não diz respeito ao universo, mas a um estado muito mais restrito" (idem). $\sim \mathrm{A}$ tem a possibilidade então de ser efetivamente um outro, para além da dependência de A: 
O conceito resultante de alteridade pode ser modelado por um número de alteridades naturais largamente utilizadas, como a de "outro lado", que não tem características hierárquicas [...] Não se trata de um cancelamento nem de uma falta ou ausência de uma condição específica, mas de uma outra e posterior condição uma diferença - produzindo o conceito de um outro que não é especificado negativamente mas é caracterizado de modo independente e com um papel independente para si (idem) ${ }^{17}$.

A filósofa não é, assim, uma inimiga da razão, mas da "razão do mestre", que se apresenta como "natural", obscurecendo seu teor político. A categoria de natureza tal como desenhada por essa razão "é um campo de exclusão e controle múltiplos, não apenas de não-humanos, mas de vários grupos de humanos e aspectos da vida humana que são elencados como natureza" (idem, p. 4). Racismo, sexismo, especismo, colonialismo, etnocentrismo e antropocentrismo seriam portanto todos derivações de um mesmo corte fundamental, aquele que separa razão e natureza, elevando a primeira sobre a segunda e denegando o caráter político dessa relação.

Antes de Plumwood e de Latour, Lévi-Strauss sintetizara esse movimento em um célebre parágrafo da conferência "Jean-Jacques Rousseau, fundador das ciências do homem", proferida em 1962:

Começou-se por cortar o homem da natureza e constituí-lo como um reino supremo. Supunha-se apagar desse modo seu caráter mais irrecusável, qual seja, ele é primeiro um ser vivo. E permanecendo cegos a essa propriedade comum, deixouse o campo livre para todos os abusos. Nunca antes do termo desses últimos quatro séculos de sua história, o homem ocidental percebeu tão bem que, ao arrogar-se o direito de separar radicalmente a humanidade da animalidade, concedendo a uma tudo o que tirava da outra, abria um ciclo maldito. E que a mesma fronteira, constantemente empurrada, serviria para separar homens de outros homens, e reivindicar em prol de minorias cada vez mais restritas o privilégio de um humanismo corrompido de nascença por ter feito do amor-próprio seu princípio e noção (Lévi-Strauss, 2013, p. 53).

$\mathrm{Na}$ história do pensamento ocidental, portanto, escravos de fato se aproximam dos animais, como asseverava Aristóteles. A cidade democrática tal como a imaginava Sócrates - que, é importante observar, não corresponde às cidades atuais pois suporia uma miríade de liberdades que não se verificam levaria a um transbordamento tamanho dessa liberdade que derrubaria os pares cidadão-imigrante, senhor-escravo, homem-mulher e animais-homens. Todos esses termos surgem enquanto subordinados no mundo ocidental, como se viu,

${ }^{17}$ Para uma exposição do conceito de negação na lógica de relevância, bem como suas diferenças em relação às lógicas clássicas, cf. Routley e Plumwood, 1985. 
pelo mesmo movimento, e sua situação político-ontológica é solidária. Nesse sentido, Bruxo, Nausicaa e Batatinha, os gatos que vivem comigo, são refugiados políticos.

Se a questão é, assim, uma de perspectiva - de sair da perspectiva do mestre e de sua razão -, a noção de objetividade tal como apresentada por Haraway em "Saberes localizados: a questão da ciência para o feminismo e o privilégio da perspectiva parcial" pode ajudar a continuar abrindo caminhos para envolver os animais e a política. No artigo, a filósofa defende, para além da oposição universalidade/relativismo, um conceito da própria objetividade que seja situado e parcial. O problema, ela explica, está em que ambas aquelas posições são descorporificadas $^{18}$ : a primeira por postular o "truque de deus", uma perspectiva de lugar nenhum, como paradigma do conhecimento; a segunda, por considerar um "imaginário dos campos de força de movimentações em um mundo totalmente textualizado e codificado" (Haraway, 1991, p. 185), a ciência como mera retórica, a história como estória, numa crença de que "todo conhecimento é um nódulo condensado num campo de poder agonístico" (Haraway, idem). As feministas, por perceberem o artifício do universalismo exclusivo, teriam por muito tempo se apegado à segunda opção, construtivista, para denunciar o caráter patriarcal e enviesado da primeira, perdendo assim a chance de se debruçarem sobre práticas científicas:

Nós desmascaramos as doutrinas da objetividade porque elas ameaçavam nosso nascente sentido de uma subjetividade histórica coletiva e de uma agência e nossos relatos "corporificados" da verdade, e terminamos com mais uma desculpa para não aprender nenhuma física pós-newtoniana e com mais uma razão para abandonar as velhas práticas feministas de autoajuda no conserto de nossos carros. São apenas textos, de todo modo, deixemo-los aos rapazes (idem, p. 186).

Para Haraway, entretanto, essa é uma solução fácil demais e que, além disso, priva o feminismo de uma teoria da ciência. Desvelar os modos pelos quais o conhecimento se constrói não é suficiente para se chegar a uma "melhor explicação do mundo; não basta mostrar a contingência histórica radical e os modos de construção de tudo" (idem, p. 187). É necessário, segundo ela, que o feminismo seja capaz de urdir um

\footnotetext{
${ }^{18}$ Uso aqui corporificado e não encarnado seguindo a própria Donna Haraway, que procura com as variantes do primeiro termo um conceito de corpo que não se reduza à carne e possa ser múltiplo, híbrido e sempre em construção.
} 
projeto de ciência sucessora que ofereça um relato mais adequado, mais rico e melhor de um mundo, de modo a nele viver bem e em relação reflexiva e crítica tanto com as nossas próprias práticas de dominação quanto com as de outros e com as partes desiguais de privilégio e opressão que compõem todas as posições (idem).

Essa tarefa, em que ética, política e epistemologia se imbricam, requer uma noção de objetividade que contemple a contingência histórica das práticas de conhecimento ao mesmo tempo em que ofereça "relatos fidedignos de um mundo 'real', um que possa ser parcialmente compartilhado e seja favorável a projetos terrenos de liberdade finita, abundância material adequada, sofrimento reduzido e felicidade limitada" (idem, p. 187). Nesse sentido, a filósofa propõe como conceito de objetividade feminista os saberes situados [situated knowledges]. Tomar a produção de conhecimento como situada significa compreender que todas as posições são marcadas - sendo aquela que se considera universal a do homem branco - e que todas elas acedem a uma objetividade - sempre parcial e localizada. Desse modo torna-se possível levar a sério a contingência e os modos de construção sem que se perca o mundo, que passa a não estar mais na ordem da transcendência e das dicotomias, mas existe corporificadamente em uma relação entre entes que não são mais sujeitos e objetos estanques. O conhecimento situado é também responsável na medida de sua capacidade "de ser chamado a prestar contas" (idem, p. 191); isso quer dizer que não se trata de um relativismo absoluto, no qual cada perspectiva valeria o mesmo que qualquer outra e nenhuma relação seria possível. Os pontos de vista das minorias, dos subjugados ou daqueles que não costumam ser levados em conta no truque totalizante de deus devem ser também críticos e, se possuem um interesse por vezes especial, é no sentido de estarem mais aptos a não aceitar esse truque, além de prometerem "algo bem extraordinário, isto é, um conhecimento potente para a construção de mundos menos organizados por eixos de dominação" (idem, p. 192).

Ser responsável e capaz de prestar contas quer dizer que nenhum ponto de vista é inocente ou imediato; nem o eu está dado de antemão, sendo a aquisição de um ponto de vista perpassada por mediações e divisões, como também é preciso saber a partir de onde se vê, diante, contra, com e apesar de quem. Em suma, é preciso sempre se perguntar "com o sangue de quem foram fabricados os meus olhos" (idem), já que "uma ótica é uma política de posicionamentos" (idem, p. 193). Isto quer dizer que é a diferença como "posicionamento crítico", e não a 
identidade, que "produz ciência" (idem) - somente a razão do mestre, para retomar o termo de Val Plumwood, se pensa a si como autoidêntica e não marcada. Por outro lado, "é o eu dividido e contraditório que pode interrogar posicionamentos e ser chamado a prestar contas" (idem). A racionalidade das epistemologias feministas deve portanto ter como "imagem privilegiada" a "divisão, e não o ser" (idem) e privilegiar na parcialidade as possibilidades de conexão e articulação.

Por último, Haraway aponta, é necessário tomar, nesse conceito de objetividade, os objetos como atores e agentes. Só assim seria possível escapar à

tradição analítica, profundamente em dívida com Aristóteles e com a história transformativa do 'Patriarcado Capitalista Branco' [...] que transforma tudo em um recurso para a apropriação, na qual um objeto de conhecimento é, no limite, ele mesmo apenas matéria para o poder seminal, o ato, do conhecedor. Aqui, o objeto tanto garante quanto renova o poder do conhecedor, mas qualquer estatuto enquanto agente nas produções de conhecimento lhe deve ser negado. Ele - o mundo - deve, em suma, ser objetificado como coisa, não como agente; ele deve ser matéria para a auto-formação do único ser social nas produções de conhecimento, o conhecedor humano [...] A natureza é apenas a matéria-prima da cultura, apropriada, preservada, escravizada, exaltada ou de outras maneiras tornada flexível para estar à disposição da cultura na lógica do colonialismo capitalista (idem, p. 197-198).

Uma tal "ativação" dos objetos e da natureza tem por consequência que a objetividade feminista não se insere na "lógica da descoberta", mas se relaciona com o mundo por meio de conversações “carregada[s] de poder" (idem, p. 198). O que Haraway chama de a lógica da descoberta é profundamente baseado em noções de gênero, como mostrou a física e feminista Evelyn Fox Keller em "Baconian Science: the Arts of Mastery and Obedience"; para ela, as imagens usadas por Bacon para ilustrar sua filosofia revelam uma dialética de dominação com tintas de gênero "que proveu a linguagem a partir da qual gerações subsequentes de cientistas extraíram uma metáfora mais consistente da dominação sexual legítima" (Keller, 2005, p. 34). Essas imagens, no que diz respeito à Ciência, figuram uma união casta, sagrada e lícita entre Intelecto ${ }^{19}$ (masculino) e Natureza (feminina), cabendo a cada parte o papel destinado ao gênero de referência com vistas ao surgimento de uma prole de "heróis e super-homens" (cf. Keller, 2005); se a Natureza por um lado fornece as regras pelas quais deve ser dominada, ela é passiva, objetificada, cabendo ao Intelecto a ação que, por meio

\footnotetext{
${ }^{19}$ Intelecto aqui traduz mind com o propósito de manter os marcadores de gênero.
} 
da sedução agressiva e da conquista, Keller observa ${ }^{20}$, resulta em dominação. Bacon-cientista, em uma passagem amplamente citada de "Temporis partus masculus, sive instauratio magna imperii humani in universum" (O nascimento masculino do tempo, ou a instauração do grande império humano no universo), de 1603, dirige-se a seus pupilos prometendo "curvar e colocar sob seu comando a natureza com sua prole ${ }^{21} "$ (Bacon, 1834, p. 224).

20 A interpretação de Keller segue até chegar a uma imagem do Intelecto como hermafrodita, começando feminino - pois passivo e limpo diante de Deus, que o engravida - até se tornar efetivamente masculino diante da Natureza: "Nos tempos contemporâneos, o papel explícito de Deus desapareceu e a fantasia científica tornou-se mais autocontida. Enquanto Bacon era capaz de dividir os aspectos duais do intelecto científico atribuindo uma dessas funções à relação do intelecto com Deus ou com a natureza divina, e a outra [função] à Natureza, os cientistas contemporâneos não o são. Para a maioria dos cientistas hoje, há apenas uma Natureza e apenas uma mente. O cientista ele mesmo assumiu a função procriadora reservada a Deus: sua mente é agora uma única entidade, tanto falo como útero. Entretanto, seu parentesco com Bacon sobrevive na simultânea apropriação e denegação do feminino" (Keller, 2005, p. 42).

${ }^{21}$ Há um grande debate e muita disputa em torno dessa passagem e de sua tradução; Fox Keller cita em seu livro a tradução do classicista Benjamin Farrington, que em The Philosophy of Francis Bacon: an Essay on its Developments from 1603 to 1609, with new Translations of Fundamental Texts, verte o trecho assim: "Venho [...] levá-lo até a Natureza para curvá-la a seu serviço e fazer dela sua escrava" (Farrington, 1964, p. 19). Críticos da interpretação de Fox Keller (cf. Le Doeuff, p. 150; Matthews, s/p) costumam apontar um erro na tradução, preferindo termos menos carregados como dar, recompensar ou ligar. A palavra que para Farrington tem o sentido de escravidão, entretanto, é "mancipaturus"; mancipatio, em latim, significa "uma transferência de propriedade [a making over], entregar, transferir de uma coisa a outra; um dos modos de adquirir posses pela lei civil romana; portanto, também à venda" (Lewis e Short, 1958, p. 1106) e podia se referir à compra e transferência de escravos, terra e gado (cf. Hunter, 1803, p. 261). O filósofo Alan Soble, a respeito da mesma passagem, lembra que se trata de um fragmento não publicado e exorta os leitores a "não levarem [as metáforas] de Bacon muito a sério como tentativas de manipulação de sua audiência ou como sinais de fumaça de seu inconsciente em ebulição. Elas são, de modo mais plausível, 'embelezamentos literários' antes que 'uma parte substantiva da ciência"” (Soble, 1995, p. 212). A filósofa ecofeminista Carolyn Merchant, outro alvo de objeções por, entre outros, ter argumentado em The Death of Nature, que "muito do imaginário [que Bacon] usava para delinear seus novos objetivos e métodos científicos são derivados do tribunal e, por tratar a natureza como fêmea para ser torturada por meio de invenções mecânicas, sugere fortemente os interrogatórios dos julgamentos de bruxas e os dispositivos mecânicos usados para torturar bruxas" (Merchant apud Merchant, 2006, p. 518), respondeu aos críticos em "The Scientific Revolution and The Death of Nature", no qual conclui que: "os esforços de Bacon em definir o método experimental foram sustentados por sua retórica e a essência mesma do método experimental emergiu de técnicas de tortura humana transferidas à natureza. Tais técnicas eram fundamentais para a dominação da natureza pela humanidade. O conceito de experimento de Bacon, junto com uma visão mecanicista dos animais como autômatos, legitimou os experimentos em animais vivos - experimentos que poderiam ser e mais tarde foram considerados tortura. Através de seu uso de metáfora, retórica e mito, Francis Bacon desenvolveu a ideia do experimento contido e controlado. Obviamente Bacon não pode ser responsabilizado sozinho pelas implicações positivas ou negativas ou pelas aplicações de suas ideias. Ele utilizou tendências existentes em sua cultura e suas ideias foram aumentadas por aqueles que seguiram sua direção. Se Bacon vivesse hoje ele poderia ou não apoiar a engenharia genética, a produção industrial de animais e a biotecnologia - em vez de rechear uma galinha com neve para ver se a putrefação poderia ser interrompida - como métodos de interrogar a natureza. Não obstante, o desenvolvimento do método científico ele mesmo foi fortemente influenciado pela retórica de Bacon e por sua visão de interrogação e controle da natureza" (Merchant, 2006, p. 532-533). 
O método de preferência é o da experimentação, que evita o surgimento de mitos como na velha ciência, abominada pelo filósofo, e força a própria Natureza a se desnudar, mostrar-se, desvelar-se, revelar-se, descobrir-se para o cientista. Os "verdadeiros fins do conhecimento", para Bacon, são uma "restituição ao e um reinvestimento [...] no homem da soberania e do poder (pois no dia em que for capaz de chamar as criaturas por seus verdadeiros nomes, ele mais uma vez as comandará) que ele tinha em seu primeiro estado de criação" (Bacon apud Fudge, p. 91). Assim é que a lógica da descoberta implementa e justifica todo tipo de experimentação nos animais outros que humanos, de modo que o homem possa novamente se elevar ao posto que ocupava antes da Queda, o que os situa atualmente em um lugar de "meras ferramentas da investigação humana" (Fudge, 1999, p. 94$)^{22}$.

O conceito feminista de objetividade e sua epistemologia baseada na ética e na política não poderiam estar mais distantes daquilo que Bacon considerava como a mais alta ambição possível, o empenho em "estabelecer e estender o poder e o domínio da própria raça humana sobre o universo", edificando assim o “império do homem sobre as coisas" (Bacon apud Keller, 1995, p. 35). O vocabulário do filósofo não está impregnado apenas por questões de gênero, mas, como na lógica do dualismo apontada por Plumwood, codifica e cartografa outros pares, tais como humano/não-humano e império/colônia - não podemos esquecer que sua obra foi escrita na aurora do século XVII. Trata-se assim de toda uma empreitada de domínio, domesticação e colonização do mundo em suas facetas feminina, selvagem e primitiva. Para Plumwood, são os dualismos os pináculos de

${ }^{22}$ Fudge argumenta que, na obra de Bacon, a passagem da infância até a maturidade e a subsequente separação do homem da esfera da natureza nunca é completada a contento; ela conclui que "dentro da lógica de suas ideias, enquanto estabelecia a possibilidade da perfeição humana baseada na separação entre o homem e o mundo natural, Bacon foi incapaz de remover o elo humano com esse mundo. Provar uma diferença satisfatória entre as espécies, um ideal baconiano, era, então, quase impossível. A biformidade [a ideia de que o corpo da Natureza era formado por uma parte superior e uma inferior, o que se poderia verificar em cada ente, composto por uma parte mais baixa e uma mais alta - o homem assim teria algo de besta, as bestas algo de vegetal e assim por diante, numa espécie de grande cadeia do ser] poderia significar um estado de oposições binárias no universo, mas era também uma admissão da proximidade em relação à besta. 'Chamar as criaturas por seus verdadeiros nomes' era exercitar a razão e o domínio sobre eles e ser inteiramente humano, mas chamar os humanos por seus verdadeiros nomes era reconhecer a animalidade da humanidade. Finalmente, e de modo inescapável, o homem de Bacon, apesar de todos os propósitos dentro de sua obra científica, seria sempre pelo menos em parte animal. A fronteira que Bacon criou para separar o homem da besta por fim revela a inseparabilidade das espécies" (Fudge, 1999, p. 106). Acredito que a hipótese do hermafroditismo dialético do intelecto elaborada por Keller e seu acento no gênero talvez seja capaz de lançar alguma luz sobre essa questão (cf. Keller, 2005). 
sustentação do império em suas formas antigas e modernas mas, como ela assevera em "Nature in the Active Voice", "a centralidade humana não é do interesse de humanos nem de não-humanos, [...] e é mesmo perigosa e irracional" (Plumwood, 2009, s/p), prenunciando aquilo que não podemos escapar de enfrentar, a catástrofe ambiental em curso. Hoje, as feições que o Império do Homem assumiram atendem por nomes como Antropoceno, Capitaloceno, Plantationoceno, Mudança Climática e Sexta Grande Extinção ${ }^{23}$, entre outros. Cada um desses conceitos dá conta de um aspecto ou dimensão de como a natureza ou as "meras coisas" responderam ao projeto de dominação. Habitamos uma guerra, nos ensina Derrida:

Trata-se de uma guerra a propósito da piedade. Essa guerra não tem idade, sem dúvida, mas, eis minha hipótese, ela atravessa uma fase crítica. Nós a atravessamos e somos atravessados por ela. Pensar essa guerra na qual estamos não é apenas um dever e uma responsabilidade, uma obrigação, é também uma necessidade, um imperativo do qual bem ou mal, direta ou indiretamente, ninguém poderia subtrairse. Doravante mais do que nunca. E digo "pensar" essa guerra, porque creio que se trata do que chamamos "pensar". O animal nos olha, e estamos nus diante dele. E pensar começa talvez aí (Derrida, 2002, p. 57).

Bruxo, Batatinha e Nausicaa me olham. Nossa vida doméstica, o pequeno espaço onde co-criamos modos de viver é atravessado e sobredeterminado o tempo todo por essa guerra, pela catástrofe de que essa guerra é uma das expressões.

\section{7. \\ Guerras felinas}

Há um livro de 2016 editado pela Oxford University Press, de autoria de Peter Marra, um conservacionista especializado em pássaros e professor do Smithsonian Institution, e Chris Santella, um consultor de marketing e escritor freelancer, autor de diversos livros de viagem do tipo "50 lugares para... antes de morrer", chamado Cat Wars: The Devastating Consequences of a Cuddly Killer. Na capa, um filhote de gato de quem só conseguimos divisar os olhos e parte das orelhas nos observa atento por detrás de uma folhagem; este pequeno gato, os autores nos dizem, e todo o povo de que ele faz parte são responsáveis por centenas de milhões de mortes de pássaros por ano, e por isso, concluem, todos os

${ }^{23}$ Cf. Chakrabarty, 2013; Danowski e Viveiros de Castro, 2014; Kolbert, 2014; Haraway, 2016b; Haraway et alii, 2016; Moore, 2016. 
gatos errantes - aquela categoria que no Brasil, como dizia Farage, foi criada no âmbito da biopolítica - devem ser erradicados. Os autores constroem seu caso abrindo o livro com a história da extinção da cotovia-da-ilha-stephen (Traversia lyalli), supostamente causada pela agência de uma única gata, chamada Tibbles, que ali vivia com o faroleiro David Lyall. A narrativa desse capítulo tem ares literários e é escrita em terceira pessoa, num discurso onisciente sobre as motivações, intenções, sentimentos e estados de espírito de Lyall. A história do faroleiro obedece a uma construção psicologizante: era um homem que desde cedo em sua vida nutria um apreço pela ordem - o que o levou a seu amor pela classificação do mundo natural -, gostava de solidão, era modesto, precisava do salário que recebia e adorava os pássaros; a instalação do farol na ilha e a mudança de Lyall para lá são contadas, por sua vez, como uma questão de necessidade:

As angloexplorações da ilha começaram nos anos 1870, lideradas por oficiais da marinha da Nova Zelândia que tinham determinado que a instalação de um farol era necessária para garantir a passagem segura através de canais próximos. Várias centenas de pessoas haviam perdido suas vidas em três grandes naufrágios em meados do século XIX na Nova Zelândia, e por isso a construção de faróis havia se tornado uma prioridade. No começo dos anos 1890, um farol e diversos lares modestos haviam sido construídos na Ilha Stephens para três faroleiros e suas famílias compartilharem (Marra e Santella, 2016, p. 50; grifo meu).

Em seguida, Marra e Santella contam a história geológica da pequena ilha, dos milhões de anos necessários para que a vida ali se desenvolvesse, contrapondo essa história vagarosa à velocidade assustadora da extinção. Eles mencionam a diminuição da biodiversidade causada na Nova Zelândia tanto pelos Maori quanto pelos colonizadores, para eles agentes de igual potencial destrutivo, e afirmam que aquela ilha, desabitada por humanos até a colonização europeia, não conhecera um "predador mamífero" antes da chegada de Tibbles (cf. idem, p. 103). A história de Tibbles é contada de um ponto de vista específico e há toda uma descrição do potencial reprodutivo e destrutivo dos gatos. Na peça produzida por Marra e Santella, a gata fora trazida até a ilha porque era costumeiro que pessoas com um trabalho tão solitário buscassem a companhia de pequenos mascotes; os mesmos autores, porém, conjecturam algumas páginas adiante que, "como a maioria dos gatos, ela tinha provavelmente uma veia feroz e independente e estava sob a impressão de que os faroleiros estivessem lá para sua diversão e companhia em vez do contrário" (idem, 124). Tibbles, eles prosseguem, não era gata de 
dormir no colo ou fazer carinhos; como os de sua espécie, e com tanto espaço para si, tornou-se selvagem muito depressa, bem como sua prole. Em um ano, e mal tendo sido descoberta, a cotovia-da-ilha-Stephen havia sido extinta pelas garras e presas de uma família. Mas nem tudo foi tragédia: o capítulo sobre a história de Tibbles e suas cotovias termina com a notícia de que uma guerra aos gatos foi declarada, chegando à marca de 100 animais abatidos a tiro em um período de dez meses, até que, finalmente, em 1925, "a ilha foi finalmente declarada livre de gatos" (idem, 178). A aventura de Tibbles na ilha Stephens é um conto moral: é preciso tomar cuidado com os gatos, eles se espalham muito rapidamente e são capazes de extinguir uma espécie inteira em matéria de meses. É preciso, “da perspectiva de ecologia da conservação", Marra e Santella concluem, "remover todos os gatos livres da paisagem por quaisquer meios necessários” (idem, p. 2505).

Não há motivo para duvidar de que as intenções conservacionistas dos autores sejam legítimas e fundadas na preocupação com a fauna silvestre a partir da qual alegam falar. Sua história inaugural, entretanto, usa de artifícios em demasia e, ademais, a conclusão a que chegam, quase um tipo de solução final felina, não poderia ser defendida tão depressa. Pensar, é preciso pensar. É preciso interromper a máquina do extermínio. E pensar diante dos animais é muitas vezes adotar a posição do idiota, este personagem conceitual de Deleuze que, nas palavras de Isabelle Stengers em "La proposition cosmopolitique",

é aquele que sempre desacelera [ralentit] os outros, que resiste à maneira como a situação é apresentada, cujas urgências mobilizam o pensamento ou a ação. E isso não porque a apresentação seria falsa, não porque as urgências seriam mentirosas, mas porque "há algo de mais importante". [...] O idiota exige que não nos precipitemos, que não nos sintamos autorizados a nos pensar detentores do significado daquilo que sabemos (Stengers, 2007, p. 47).

É preciso frear as soluções que parecem fáceis demais e nas quais a vida de bilhões de outros estão em jogo. "Quaisquer meios necessários” não parece um bom caminho para nenhuma prática, por melhores que sejam as intenções de quem o sugere, por mais vidas, neste caso de aves, que se pretenda conservar. A "proposta cosmopolítica" de Stengers não pretende construir um cosmos bom e comum - isso seria, talvez, nas palavras de Haraway, o truque de Deus -, mas justamente "desacelerar [a sua] construção, [...] criar um espaço de hesitação diante do que significa dizer 'bom"' (idem, p.48): 
O cosmos tal como se configura neste termo, cosmopolítica, designa o desconhecido que constitui esses mundos múltiplos, divergentes e as articulações de que eles podem se tornar capazes contra a tentação de uma paz que se deseja final, ecumênica, no sentido no qual uma transcendência teria o poder de exigir daqueles que divergem que se reconheçam como uma expressão apenas particular daquilo que constitui o ponto de convergência de todos (idem, p. 49).

Exigir a supressão dos gatos errantes ou livres do mundo seria exigir que nós, que cultivamos com eles uma relação de milhares de anos, tomássemos uma decisão mortífera contra eles, como se fôssemos responsáveis diante das aves mas não dos felinos - que, de fato, matam aves. Até onde se pode ver, entretanto, nem os predadores nem as presas foram, no livro de Marra e Santella, chamados a dar sua opinião. Mas, perguntar-se-á, como eles poderiam fazer isso? Stengers explica que a cosmopolítica opera por meio da criação de uma inquietude entre as vozes políticas que as faz sentirem "que a arena política é povoada pelas sombras do que não tem, não pode ter ou não quer ter voz política" (idem). Seu primeiro exemplo no artigo diz respeito justamente a animais, no caso os de laboratório, as cobaias; a autora pede que se deixe de lado as situações mais simples, de puro abuso digamos, cobaias de testes cosméticos -, para pensar aquelas outras em que não há uma resposta simples ou nas quais não há espaço para qualquer resposta que se pretenda definitiva, como no caso da luta contra uma epidemia. Nesse cenário há uma miríade de atores com e sem voz diante de quem se deve pensar e frear a tomada de decisões em nome do "mundo comum". Não há mundo comum aí que não se revele danoso a alguém. O que interessa, ela sublinha, não é a criação de uma escala de interesses ou de seres, na qual uma espécie ou indivíduo valeria mais que outro ou a urgência de um seria mais intensa que a de outro. Esse tipo de "colocação em equivalência de tipo utilitarista", Stengers lembra, "abre-se a todas as vilanias: ela incita cada um a reenviar a uma conta comum a responsabilidade das consequências de sua própria medida” (idem, p. 51).

É preciso então uma "ecologia de práticas" de caráter não policial, o que Stengers chama de etoecologia: ao afirmar a inseparabilidade - mas não a dependência funcional - entre ethos, o modo de habitar, e oikos, o lugar da habitação, a autora aponta para uma ecologia política transformacional não controlada de tipo alquímico. Um ethos não surge necessariamente de um oikos, “ele será sempre aquele do ser que se revele capaz" (idem, p. 52), mas uma mudança de oikos considerado como ambiente causa uma mudança imprevisível 
no ethos: "O ambiente, poder-se-ia dizer, propõe, mas é o ser que dispõe dessa proposição, que lhe dá ou lhe recusa uma significação 'etológica'” (idem). Aquilo a que Stengers convida é uma mudança de oikos com vistas ao surgimento de novos ethoi: como agiriam os cientistas em um biotério se seus ethoi, que "parecem ter necessidade de um ambiente asséptico" (idem, p. 52-53) fossem confrontados com o povoamento deste ambiente pelas consequências que atingem cada um dos animais utilizados? O que seria dessas práticas caso fosse necessário levar em conta, a cada experimento, que o que se pratica não é "sacrifício" ou "abate", mas o assassinato de alguém? Isto não quer dizer que as experimentações cessariam, mas talvez seu ritmo diminuísse. Ainda, o que aconteceria se os animais de laboratório fossem nomeados, conhecidos, lembrados em datas especiais, se em seu nome estátuas fossem $\operatorname{erguidas}^{24}$, se fossem considerados coautores dos fármacos que se produzem com eles, heróis responsáveis pela erradicação ou controle de uma doença? Esse novo oikos certamente traria consigo novos ethoi. É nesse sentido que a proposta de Stengers se diz "cósmica" (idem, p. 52).

De certa forma, essa proposição se aproxima daquela de Deleuze sobre os cavalos de trabalho e de corrida e da questão de Spinoza sobre o que pode um corpo. Em La sorcellerie capitaliste, livro escrito por Stengers com Philippe Pignarre, eles explicam que

um etólogo digno do nome não tenta definir o animal estudado, dizer "o que é um babuíno", por exemplo, mas antes procura descrever e caracterizar aquilo de que um babuíno é capaz em situações concretas, habituais ou inéditas (Pignarre e Stengers, 2005, p. 35).

No mesmo espírito, em uma aula sobre Spinoza de 09/12/1980, Deleuze havia comentado:

Eu me pergunto qual é o primeiro sentido mais imediato da palavra ética, no qual ela seja outra coisa que a moral? E, bem, eu diria que a ética nos é mais conhecida hoje sob um outro nome, que teve um desenvolvimento de certo sucesso: é a palavra etologia.

Quando se fala de uma etologia sobre os animais, ou mesmo de uma etologia sobre o homem, do que se trata? A etologia no sentido mais rudimentar é uma ciência

${ }^{24}$ Na Rússia, no Instituto de Citologia e Genética da Universidade de Novosibirsk, foi erigida em 2013 uma estátua em homenagem aos ratos que foram usados por/trabalharam com/auxiliaram os cientistas em pesquisas genéticas. $\mathrm{O}$ escultor, Andrew Karkhevich, comentou a respeito de sua obra, um rato antropomorfo tricotando espirais de DNA, que "ela combina a imagem de um rato de laboratório e a de um cientista, pois ambos se interligam ao servir ao mesmo caso." (cf. http://boingboing.net/2014/01/17/a-monument-to-laboratory-rats.html e http://politsib.ru/news/64989) 
prática, de quê? Uma ciência prática de maneiras de ser. Então eu diria: a maneira de ser é precisamente o estatuto dos seres, dos existentes, do ponto de vista de uma ontologia pura (Deleuze, s/d, s/p).

Não se trata, assim, como já não era o caso nos outros autores comentados, de um abandono ou uma dúvida acerca da ciência, mas de que os saberes não podem se pretender descorporificados, fora de seu oikos, "independentes daquilo que [...] [este] lhes impõe levar em conta ou lhes permite, pelo contrário, ignorar" (Stengers, 2007, p. 53). Em suma, trata-se de sempre revelar e levar em conta as situações ecológicas, etoecológicas, e de favorecer o surgimento de novas éticas/etologias pela multiplicação de atores, práticas e consequências no ambiente.

Para Stengers, evocando Latour, a cosmopolítica enquanto ecologia política diz respeito não mais a matters of fact (matérias de fato), de cujas "razões autorizadas" "a situação escapa" (idem, p. 54), mas a matters of concern (matéria de preocupação), na medida em que as situações devem ser produzidas pela coleção "de todos aqueles que são "concernidos"” (idem). Não se trata de uma luta do Bem contra o Mal ou da vitória dos bons, mas de indicar "por onde poderia passar uma transformação que não deixasse ninguém ileso" (idem, p. 56). Pois bem, talvez seja possível considerar a questão das "cat wars" em sua expressão na ilha Stephens uma matter of concern que diz respeito à colonização, isto é, a colonizadores e colonizados, a Tibbles, seus filhotes e seu faroleiro, às cotoviasda-ilha-stephen, a Marra e Santella e a todo o povo dos gatos que, através dessa narrativa, se vê diante de uma guerra de Estado contra si (não se deve esquecer aqui das políticas públicas de eutanásia que vigoram por todo o globo). Ela se aproxima da matter of concern que diz respeito aos três gatos que vivem comigo e a sua situação de refugiados. Retorno então a essa questão, desta vez com o "murmúrio do idiota" (cf. Stengers, 2007), procurando reimaginar o mundo e contar outra história, no espírito da sexta das Teses sobre o conceito de história de Benjamin, que adverte: "também os mortos não estarão em segurança se o inimigo vencer." Recomeço, então.

O que primeiro chamou a atenção na narrativa de Marra e Santella foi seu total desinteresse pela questão colonial; eles omitem o fato de que a população europeia na Nova Zelândia havia aumentado de 1.000 habitantes em 1831 para 500.000 em 1881. Não é preciso muita imaginação para concluir que a quantidade 
de recursos necessários à manutenção de um número tal de pessoas fosse enorme. A ilha Stephens era chamada Takapourewa pelos Maori e é difícil encontrar, nas narrativas sobre o desaparecimento da cotovia, informações sobre a relação dos povos indígenas com ela ou com o lugar além da informação de que "se os Maori a tinham visitado, não deixaram traço" (Marra e Santella, 2016, p. 51). Um texto de 1894 no jornal neozelandês The Colonist, de autoria de Edward Lukins, descrito como um "colecionador ardente de espécimes de história natural e objetos de interesse geral" (The Colonist, Nelson, 27/10/1894), conta sua chegada à ilha junto com um certo Mr. Webber e um barqueiro não identificado; eles levavam "correspondências, nove ovelhas vivas e outras mercadorias necessitadas" (idem). Este Mr. Webber tinha um contrato que lhe permitia, a cada três meses, ir até a ilha entregar correspondências e mercadorias aos moradores do farol e por isso concordou em transportar o curioso. Lukins menciona em seu artigo um ou mais cavalos que faziam o transporte, trilhos usados exclusivamente para a entrada de "suprimentos, combustível e assim por diante" (idem), escola, estábulos, o farol, a similaridade da vegetação local com as outras ilhas da região à exceção de árvores anãs que só avistara ali, o mar bravio, o vento, dois tipos de caracóis e pelo menos 33 espécies de aves nativas.

Todos os relatos de conservacionistas a que tive acesso e que dão conta da extinção do pássaro começam pela chegada dos colonizadores. Pelo que pude pesquisar, em janeiro de 1894, com a inauguração do farol, além de Lyall, outras 16 pessoas se mudaram para lá, desmatando parte da ilha para suas roças e para a criação do gado bovino e ovino que haviam levado consigo (cf. Galbreath e Brown, 2004; Donald et alii, 2010). Segundo Paul Donald, que por 20 anos foi membro da Royal Society for the Protection of Birds (RSPB), entidade fundada em 1891 por Emily Williamson e Eliza Philips, possivelmente em fevereiro de 1894 uma gata grávida chegou também à ilha, tendo dado à luz uma ninhada que, por não ter sido acolhida pelas famílias da ilha, tornou-se feral. Essa gata teria começado a trazer pequenos cadáveres de um certo pássaro para casa e Lyall, "que era interessado pela vida selvagem, enviou um desses [corpos] através de A.W. Bethune, segundo engenheiro no navio a vapor do governo Hinemoa, para Sir Walter Buller" (Donald et al, 2010, p. 111). Buller, profundo conhecedor de pássaros, compreendeu tratar-se de uma nova espécie e a descreveu em um artigo, comentando "o quão satisfeito" ficou "ao receber [...] a pele de um pássaro da ilha 
Stephens que era inteiramente diferente de tudo até aqui conhecido" (Buller apud Donald et alii, 2010, p. 112). Porque Buller demorou a publicar seu artigo, aguardando ilustrações que viriam de Londres, e Lyall continuou vendendo os corpos que sua gata lhe trazia para negociantes que movimentavam todo um mercado de compra e transporte de animais vivos e mortos a preços altos em uma corrida pelo status de possuí-los vivos ou pela honra da descrição de uma nova espécie, foi Walter Rothschild quem, afinal, na posse de nove pequenos cadáveres supostamente trazidos pela gata de Lyall, pôde anunciar em 1894, no British Ornithologists' Club, sociedade fundada um ano após a RSPB, a descoberta da cotovia, por ele batizada de Traversia lyalli. Rothschild, um colecionador naturalista e dono de um museu particular, era muito mais rico que Buller, e, por isso, Henry H. Travers, que havia comprado os nove espécimes de Lyall, os ofereceu a ele. Em carta datada de 9/10/1894, Travers explica a Rothschild o motivo de ter oferecido todos os pássaros de uma vez: “As rock wrens são muitos difíceis de se conseguir, e em pouco tempo não haverá mais nenhuma. Nunca vi muitas delas e penso que nunca foram muito comuns" (Travers apud Galbreath e Brown, 2004, p. 194). Uma outra carta de Travers a Rothschild, escrita quase seis meses depois, em 7/03/1895, ilustra a relação dos colecionadores e entusiastas com a fauna nativa.

Espécimes vivos foram vistos apenas duas vezes e, em cada ocasião, a pessoa que os viu não tinha arma; ela afirmou que [o pássaro] estava correndo por entre as pedras como um rato, e era tão rápido em seus movimentos que ela não conseguiu chegar perto o suficiente para golpeá-lo com um pau ou pedra (Travers apud Galbreath e Brown, 2004, p. 195).

O filho do sr. Lyall me deu um espécime que foi encontrado vivo pelo dono do gato que pegou os outros, e que seu pai havia colocado em espírito [colocado a ave inteira em um recipiente cheio de álcool] (idem, p. 196).

A história da gata prenha também é narrada por Travers, em carta de 27/12/1898, e contradiz a narrativa de Marra e Santella sobre o elo entre faroleiros e felinos:

Eu estive na ilha Stephens há cerca de 4 anos e a ave acima [piopio], philesturnus [saddlebacks] de ambas as espécies, robins e outras aves eram comuns, mas muito especialmente a última, que havia às centenas. Agora não há uma só da última ou da segunda $\&$ apenas muito poucas das outras, tudo devido ao fato de que uma gata pesada em filhotes foi trazida de French Pass em um saco pelo dono, com a intenção de ser jogada para fora do barco no caminho até a ilha. Mas à medida que veio o mau tempo, o gato foi esquecido até que se alcançasse a ilha, quando na pressa do desembarque o saco com o gato foi posto em terra firme, e um dos 
homens, sem pensar, cortou o saco e deixou o gato sair. A ilha agora está repleta de gatos (idem, p. 1999).

Em 1895, um ano após a descrição da cotovia, Travers liderou uma expedição até a ilha com o intuito de caçar novos indivíduos - além de outros, de outras espécies que fossem lucrativas - mas não encontrou nenhum. Em março de 1895, a cotovia-da-ilha-stephen foi declarada extinta. O incidente acerca da descoberta causou a dissolução da amizade entre Buller e Rothschild, que passou a escrever uma série de artigos críticos ao antigo amigo mesmo depois de sua morte. Segundo Donald, foi ele quem provavelmente deu início ao mito da extinção da cotovia por um único gato. Digo mito pois é assim que a maioria das pesquisas a respeito do acontecido se refere à narrativa que responsabiliza Tibbles - se é que a gata se chamava assim - pelo desaparecimento de toda uma espécie em apenas um ano. Acontece que 1. Não havia só um gato na ilha, as informações dão conta de que toda uma colônia de ferais andava por lá; 2. A cotovia não se extinguiu em 1895, havendo diversos documentos que atestam o surgimento de novos cadáveres no mercado de espécimes; 3. Não se pode subestimar o impacto deste mercado e do desmatamento provocado pelos colonos. Galbreath e Brown concluem seu artigo afirmando que provavelmente foi a predação felina a causa principal da extinção da cotovia, antes da destruição de habitat e dos coletores de cadáveres; esta ação, entretanto, não foi obra de um único gato, e tampouco ocorreu tão depressa quanto se costuma crer. Uma história trágica, certamente, e que, segundo os autores, foi causada pela "exploração da ilha" (idem, p. 193), “apenas mais uma das baixas da exploração humana" (idem, p. 200).

O que essa narrativa, elaborada a partir de textos publicados antes do livro de Marra e Santella, isto é, a partir de fontes disponíveis à época da escrita de seu livro, parece dizer, em primeiro lugar, é que a cotovia-da-ilha-stephen pereceu devido ao empreendimento colonizatório com seu transporte indiscriminado de genoma pelo globo e sua lógica do mestre, que vê o mundo como mero recurso. Não seria justo concluir, como Galbreath e Brown, que a tragédia da cotovia se deveu à exploração humana; as diferenças internas à humanidade permitem afirmar com uma certa segurança que essa exploração teve origem no colonialismo - ocidental, branco, de polo masculino, em suma, senhorial. A gata grávida que escapou da morte para ver sua prole tomar conta da ilha por cerca de 
três décadas até seu extermínio total não chegou ali como um animal de companhia, embora a relação de seu povo com o povo que a transportou até a ilha fosse de cooperação ancestral. Transformar a sua história em uma história contra os gatos e a favor da biodiversidade, quando houve tantos outros atores envolvidos na extinção da cotovia, quando a gata sobreviveu por mera contingência, quando era também a sua vida que estava em jogo é, no mínimo, reducionista. E no entanto resta o problema: os gatos realmente parecem ter sido a causa eficiente - ainda que talvez acidental - do desaparecimento dos pássaros. Que se possa atribuir à colonização a causa final não os apaga enquanto agentes, o que remete ao problema atual: é possível usar essa história para justificar a eliminação dos gatos errantes?

Essa não é uma situação simples, mas uma daquelas em que qualquer solução será danosa a alguém. Entretanto, em vez de aceitar ter que escolher entre gatos e aves, é preferível hesitar, invocar mais uma vez o idiota. Em sua coluna no site Psychology Today, o etólogo Marc Bekoff fez um apelo: “com diversas outras pessoas, tenho me perguntado quando a 'matança em nome da conservação' cessará” (Bekoff, 2016, s/p). Bekoff adverte para o fato de que uma afirmação do tipo "por quaisquer meios necessários", sobretudo quando proferida em nome da ciência, pode trazer consequências nefastas para as populações de gatos. As "cat wars" nada mais são que guerras contra gatos. Além dos argumentos sobre a impraticabilidade do extermínio de uma espécie em áreas não controladas, diferente do caso de ilhas diminutas como a Stephens, de um quilômetro e meio quadrado; de todo o tipo de efeito colateral que uma empreitada assim produziria (morte de outros animais por envenenamento etc.); da rejeição simplista e negligenciadora de estudos a respeito da eficácia de práticas do tipo capturaesterilização-devolução; das inconsistências a respeito do potencial danoso dos felinos a ecossistemas; isto é, além dos argumentos científicos contra a proposta de eliminação dos gatos das paisagens, há um ponto de Bekoff que merece atenção redobrada: a falsa escolha, a falsa guerra.

Stengers e Pignarre, em La sorcellerie capitaliste, tratam de um tipo de falsa escolha imposta pelo capitalismo, à qual chamam de "alternativa infernal", o modo mesmo pelo qual este sistema "mata a política" (Pignarre e Stengers, 2005, p. 41): "Ali onde se constitui uma alternativa infernal, a política dá lugar à submissão, e mesmo aqueles e aquelas que resistem podem ser capturados, isto é, 
podem definir sua oposição nos termos fabricados pela alternativa" (idem, p. 4142). A falsa escolha é, portanto, fabricada de modo a promover a morte da política. Não se deve, entretanto, para os autores, parar aí, na denúncia, mas é preciso "recolocar na política isso que hoje se apresenta nos termos de uma alternativa infernal" (idem, p. 42). Se é justo chamar a escolha entre pássaros e gatos de alternativa infernal, então é necessário tratá-la de modo que ela retorne à política. Isso significa, em primeiro lugar, compreender que não existe um povo dos gatos, ou aliado dos gatos, contra um povo dos pássaros, ou aliado destes, como os autores querem fazer parecer. Não há uma guerra nem entre humanos nem entre gatos e aves para que alguns humanos - não todos, como sempre, mas apenas aqueles qualificados - arbitrem. Pensar assim é aderir à razão do senhor e ao saber descorporificado. Isso não significa que não haja problemas e que "o lobo habita com o cordeiro"; significa pensar para além de políticas estatais de extermínio de populações; significa pensar e agir de modo prático, reunindo saberes diversos, diante de e com os animais em questão em cada situação particular; significa, enfim, se implicar em lugar de julgar.

\section{8 . \\ Habitar o problema}

A palavra Antropoceno aparece uma única vez em Cat Wars, no capítulo 4, intitulado "A ciência do declínio." Nele, Marra e Santella concluem que, diante da perda acelerada da biodiversidade causada pelo anthropos, diante da Sexta Grande Extinção, a ação dos... gatos (!) é especialmente problemática. A prestigiosa editora Princeton University Press descreve seu produto em release como um "retrato revelador de um complexo problema global - e propõe soluções que anteveem uma época na qual a vida selvagem e os humanos não seriam mais vulneráveis aos impactos dos gatos livres", como se fossem os gatos os maiores responsáveis pela degradação da vida na Terra; este texto carrega ainda nas tintas conspiratórias ao sugerir que a obra de Marra e Santella

descreve como uma pequena mas sonora minoria de defensores de gatos têm feito campanhas de sucesso em muito semelhantes ao modo como grupos de interesse especial frustraram as tentativas de redução do tabaco e da mudança climática. ${ }^{25}$

25 O release do livro pode ser encontrado no site da PUP http://press.princeton.edu/titles/10809.html, bem como nos das lojas que o comercializam. 
Para os autores e sua editora, as associações de amigos dos gatos, que eutanasiam um número incontável de animais por ano mundo afora, além de promover campanhas para que os gatos pets não tenham acesso à rua, para que se instalem telas de segurança nas residências, que mantêm abrigos onde são acolhidos outro sem número de gatos indesejados, que reabilitam animais antissociais, que os esterilizam e imunizam, entre outras atividades, por não defenderem o extermínio generalizado dos gatos livres, agem de maneira semelhante (inclusive com poder e influência equivalentes) a corporações como as petroleiras e a indústria do tabaco. E com os mesmos efeitos nocivos. Mais adiante, no capítulo 8, intitulado "Uma paisagem com menos gatos livres: melhor para os gatos, melhor para as aves, melhor para as pessoas", o seguinte argumento é apresentado:

\begin{abstract}
É abundantemente claro que gatos livres não são a ameaça principal ao futuro dos pássaros e da vida selvagem. Tanto a destruição de habitat como a mudança climática e a poluição exercem influência sobre o bem-estar [well-being] de populações selvagens; se nós, como uma sociedade, esperamos manter essas espécies para gerações futuras, precisamos agir em todas as frentes para estancar a maré. Sob a mesma luz, devemos agir em muitas frentes diferentes para reduzir a população de gatos livres e reduzir seu impacto sobre as populações animais nativas, tanto como predadores quanto como vetores de doenças. Nenhuma solução será mágica; apenas uma abordagem multifacetada começará a reduzir o número de gatos livres na natureza [in the wild]. Uma paisagem sem (ou no mínimo com menos) gatos livres é a única esperança para mitigar os custos que esses animais impõem à vida selvagem nativa e diminuir a transmissão de doenças de gatos a populações humanas (Marras e Santella, 2016, p. 2387).
\end{abstract}

Diante das maiores ameaças à biodiversidade, os autores escolhem não a luta contra o uso de combustíveis fósseis, o desmatamento, a indústria da carne ou outras (em nenhum momento no livro a palavra "capitalismo", por exemplo, aparece), mas a frente da eliminação dos gatos livres. "Nenhuma solução será mágica", dizem. Mas fica a impressão de que é exatamente isso o que os autores oferecem, um truque mal articulado que distribui responsabilidades tão velozmente quanto se exime delas. Não fosse assim, como justificar sua resistência diante da captura-esterilização-devolução, um método de controle de populações considerado eficaz (mas não messiânico) segundo uma série de pesquisas ${ }^{26}$ ? A C.E.D. evita o extermínio e promove uma convivência situada, pacífica, não-simétrica e não-ingênua entre humanos, gatos e demais populações animais. Os gatos esterilizados e imunizados que são soltos protegem seu

\footnotetext{
${ }^{26}$ Para uma exposição detalhada da prática e seus efeitos, cf. http://www.aspca.org/aboutus/aspca-policy-and-position-statements/position-statement-community-cats-and-community-cat.
} 
território de outros possivelmente doentes ou agressivos, restaurando o antigo acordo eles e os humanos de que a história da co-domesticação é testemunha. A prática, entretanto, não dá conta de todas as situações: em ecossistemas isolados como ilhas, é preciso negociar de outro modo; não se tem nenhuma garantia de que não haverá mortes, assassinatos, seja de gatos ou de aves. É preciso considerar cada caso de modo singular, a partir de tentativas e considerando experiências bem sucedidas. O que não se deve perder de vista é que isso não pode querer dizer declarar guerra a todo um modo de vida, o dos gatos livres, muito menos considerar que se trata de uma questão de escolher lados - um lado do bem, o dos pássaros, e um lado mau, o dos predadores felinos. Ou o inverso.

Em 2002 a RSPB liderou um projeto de extermínio de gatos na ilha de Ascenção, um território inglês no meio do Oceano Atlântico, à meia distância entre a América do Sul e a África, com métodos aprovados pela Royal Society for the Prevention of Cruelty to Animals. Quatro anos depois, sem felinos, as populações de fragatas voltaram a prosperar; por outro lado, sem predadores, o número de ratos-pretos aumentou de tal forma que passou a ameaçar uma outra espécie de ave, a andorinha-do-mar-escura (cf. Harper e Bunbury, 2015). Uma história de como a manutenção da vida é mais complicada e frágil do que sugere uma decisão régia da subtração de um povo. Mas essas informações não desenham todo o quadro e a grande quantidade de fatores em questão transborda do raciocínio apequenado das causalidades simples. Jim Reynolds, ornitólogo da Universidade de Birminghan, em entrevista sobre o caso ao jornal The Telegraph, explicou que o sucesso dos ratos diante das andorinhas tem por causa provável a dieta pobre das aves, que as enfraquece e é causada pela diminuição dos cardumes na região. A diretora de conservação e pesca do governo da ilha de Ascenção, Judith Brown, afirmou na mesma matéria não haver dados suficientes para responsabilizar os ratos pelo declínio do número de andorinhas; segundo ela, a disponibilidade de peixe seria a causa mais provável. Quanto aos ratos, Brown explicou que a mudança climática tem favorecido o aumento de espécies de plantas invasivas que proveem comida e abrigo a eles. A matéria termina, entretanto, com uma declaração da RSPB atestando já ter conduzido programas de erradicação de ratos no passado (cf. Knapton, 2016). Mesmo reconhecendo o fracasso de uma decisão pelo extermínio, retorna-se a ela pois a estrutura de 
pensamento permanece igual, ainda que o mundo resista às lógicas simplificadoras de domínio.

Contra a feitiçaria do senhor e suas alternativas infernais ${ }^{27}$, é preciso cultivar outros tipos de feitiçaria ou bruxaria, aqueles de que Stengers fala em "A proposta cosmopolítica", e que se constituem como "a arte de suscitar eventos nos quais esteja em jogo um 'tornar-se capaz"” (Stengers, 2007, p. 62):

[...] convocação daquilo cuja presença transforma as relações travadas por cada protagonista com seus próprios saberes, esperanças, medos, memórias e que permite ao conjunto fazer emergir o que cada um, separadamente, é incapaz de produzir. [...] Arte da imanência radical, mas a imanência é justamente aquilo que precisa ser criado [qui est à créer], o regime usual de pensamento sendo o da transcendência que autoriza a tomada de posição e o julgamento (idem, p. 62).

Uma bruxaria desse segundo tipo faz uma breve aparição em Cat Wars sob a forma a aliança entre a Audubon Society of Portland, entidade conservacionista cujo foco são pássaros, e a Feral Cat Coalition of Oregon, ainda que se estenda apenas por uma página. No lugar da oposição propalada pelos autores entre "cat people", "bird people", gatos e aves, as duas entidades se uniram há cerca de dez anos por acreditar que, juntas, poderiam fazer algo de que nenhuma das duas seria capaz só. Em primeiro lugar, apostam que se trata de uma mesma luta e não de lados antagônicos; é a partir daí que ficam claros os desafios nada fáceis de como articular essa luta com os animais e a sociedade humana. A ASP e a FCCO mantêm juntas o projeto "Cats Safe at Home", que promove campanhas para

\footnotetext{
${ }^{27}$ Pignarre e Stengers interpretam o capitalismo como um sistema de feitiçaria no qual está em jogo "vender a alma, perder a alma, ter a alma capturada" (idem, p. 58); "se o capitalismo entra em uma tal linhagem, é de um modo muito particular, aquele de um sistema de feitiçaria sem feiticeiros que se pensam como tais, um sistema que opera em um mundo que julga que a feitiçaria não é senão 'uma simples crença', uma superstição, e não necessita então de nenhum meio adequado de proteção. E, desde esse momento, a relação com os 'outros', tomados como supersticiosos, se encontra transformada. Pois pensar que não se tem necessidade de proteção revela uma imprudência que para esses 'outros' reputados supersticiosos, se aparentaria à mais assustadora ingenuidade: a seus olhos, o desastre se torna assim previsível. O risco pragmático é o de aceitar a chance desse desastre, quer dizer, de constituir a questão de nossa vulnerabilidade e de aprendizagem de precauções necessárias como problema crucial" (Pignarre e Stengers, 2005, p. 59). Uma outra relação entre capitalismo e feitiçaria ou, neste caso, bruxaria, é delineada pela feminista Silvia Federici em Caliban and the Witch. Women, the Body and Primitive Accumulation, livro no qual a autora faz uma "descrição da acumulação primitiva" que "inclui (i) o desenvolvimento de uma nova divisão sexual do trabalho que subjuga o trabalho das mulheres e a função reprodutiva das mulheres à reprodução da força de trabalho; (ii) a construção de uma nova ordem patriarcal baseada na exclusão feminina do trabalho remunerado e sua subordinação aos homens; (iii) a mecanização do corpo proletário e sua transformação, no caso das mulheres, em uma máquina para a produção de novos trabalhadores. Mais importante, no centro de minha análise sobre a acumulação primitiva situei a caça às bruxas dos séculos 16 e 17, argumentando que a perseguição às bruxas, na Europa e no Novo Mundo, foi tão importante quanto a colonização e a expropriação do campesinato de sua terra foram para o desenvolvimento do capitalismo" (Federici, 2004, p. 12).
} 
convencer os humanos que vivem com gatos a esterilizá-los e mantê-los dentro de casa, além de fazer um controle populacional na ilha Hayden ${ }^{28}$. Manter os gatos dentro de casa e esterilizá-los são ações que promovem o bem-estar tanto dos felinos quanto das aves; os primeiros ficam longe de perigos do tipo atropelamentos, envenenamentos, agressões por humanos etc.; os segundos, longe de seus predadores. Não se trata de uma via de mão única, mas uma que requer o comprometimento - e não o policiamento - de todos os envolvidos. Na ilha Hayden, um pequeno pedaço de terra entre Vancouver, WA, e Portland, habitado por cerca de 2.000 humanos e algumas centenas de gatos, entre uma miríade de outros animais, a parceria promove a contagem regular de gatos, sua esterilização e devolução, além de cuidados veterinários e disponibilização de informação.

Em Cat Wars, os autores descrevem parte do território da ilha como tendo sido "destinado para uso industrial", mas observam que "muitas centenas de acres permanecem não-desenvolvidos, provendo o habitat para algumas das 200 espécies de aves da área.” A ilha, segundo eles, "também tem sido usada como um local de desova de gatos indesejados" (Marra e Santella, 2016, 2577). Essas muitas centenas de acres não-desenvolvidos a que se referem os autores provavelmente são a parte da ilha conhecida como West Hayden, uma área em constante disputa. Acontece que o porto de Portland, que tem a propriedade dessa parte da ilha, vem tentando há anos implementar ali um projeto de desenvolvimento que, em sua última encarnação, em 2008, previa o uso de 300 acres para construções do porto e a criação de uma reserva nos 500 acres restantes. Segundo a companhia, a instalação na região de um terminal de águas profundas, do tipo capaz de receber cargas pesadas, criaria milhares de empregos, além de movimentar 30 milhões de dólares por ano. Parte dos moradores da região, ambientalistas, nações indígenas e a ASP formam a resistência contra o projeto. No site da ASP, cujo lema é "Building a region where people and wildlife flourish together", há uma documentação extensa a respeito dessa batalha, que foi vencida pelos ativistas em 2014, quando o diretor executivo do porto, Bill Wyatts,

28 Informações sobre o projeto podem ser encontradas no site das duas entidades: http://audubonportland.org/ e http://www.feralcats.com/; para o trabalho na ilha Hayden, cf. o relatório de 2015 http://audubonportland.org/files/habitat/2014-hayden-island-cat-report. 
retirou o projeto, mas não sem acrescentar que voltaria a tentar desenvolver a ilha, "apenas não agora. ${ }^{29 "}$

Dentre as falas em audiências públicas no decorrer do processo, é interessante destacar duas, de representantes de dois povos indígenas, ambas publicadas no site da ASP:

Esta ação impactaria recursos de pesca garantidos por tratados, assim como nossa visão de restaurar a saúde e a produtividade do rio Columbia. Somos compelidos a nos opor a esta ação por ela ser contrária aos interesses e esforços na Nação Yakama de preservar, proteger e aprimorar os trust resource ${ }^{30} s$ do tratado e os direitos de pesca. As ações propostas por esta anexação fracassam em proteger adequadamente os recursos do rio e esse é o pilar da oposição da Nação Yakama. O dano causado a estes valiosos recursos não poderia depois ser desfeito. Os benefícios ecológicos e valores que o ecossistema de West Hayden proporcionam são insubstituíveis para a manutenção do funcionamento próprio do ecossistema do rio Columbia ${ }^{31}$ (Roger Dick Jr).

A tribo Nez Perce tem trabalhado incansavelmente por muitos anos para proteger e restaurar as populações de salmão do rio Columbia. A West Hayden Island provê um habitat importante para o salmão e outras espécies ameaçadas, ameaçadas de extinção e sensíveis, incluindo a lampreia-do-pacífico. Os habitats como as águas rasas, a planície de inundação, os pantanais, as pradarias, a praia e a floresta merecem todos proteção permanente em vez de um desenvolvimento industrial de larga escala. A cidade de Portland deveria estar trabalhando para transformar a ilha em uma área de proteção natural, não para apoiar um terminal marinho para o qual há pouca demanda. Os prováveis impactos ao salmão, à lampreia e a outras espécies de importância tribal são simplesmente grandes demais para justificar a anexação e o zoneamento industrial da ilha ${ }^{32 "}$ (Silas Whitman).

Bob Sallinger, diretor de conservação da Audubon Society of Portland, também se opôs pessoalmente e em nome da instituição ao projeto do porto. Finalmente, mas apenas por hora, a coalizão que ali se formou para a proteção de West Hayden, foi vitoriosa. Não há gatos na história do porto de Portland, mas houve uma aliança entre diferentes, de diferentes interesses, pela preservação de um ecossistema - este mesmo uma espécie de aliança. Há também o entendimento de que não há solução mágica ou decisão de um árbitro onisciente. O que há são acordos localizados e temporais com vistas a uma melhor convivência e ao

29

http://www.oregonlive.com/business/index.ssf/2014/01/port_of_portland_shelves_plans.html.

30 "O termo 'trust resources tribais' diz respeito aos recursos naturais, dentro ou fora de terras indígenas, retidos ou reservados por ou para tribos indígenas por meio de tratados, estatutos, decisões judiciais e ordens executivas que estão protegidos por uma obrigação fiduciária por parte dos Estados Unidos" (https://www.fws.gov/endangered/what-we-do/tribal-secretarial-order.html)

${ }^{31} \mathrm{http}: / /$ audubonportland.org/issues/habitat/urban/hayden/blog/may18-2013.

32 http://audubonportland.org/issues/habitat/urban/hayden/blog/may17-2013/. 
florescimento de "mundificações"33 diversas em uma terra já danificada. Parafraseando Haraway, a lição desse tipo de acordo passa pela possibilidade de recuperações parciais de associações multiespecíficas, com a intenção de estabelecer continuidades de modos de estar e de fazer mundos em meio à catástrofe:

Diante da implacável superabundância historicamente específica de sofrimento nos enlaçamentos das espécies companheiras, não estou interessada em reconciliação ou restauração, mas estou profundamente comprometida com as possibilidades mais modestas de recuperação parcial e de nos darmos bem juntos [getting on together]. Chamemos isso de conviver com o problema [staying with the trouble] (Haraway, 2016b, p. 10).

Conviver com o problema, como entendo a expressão, também é um modo de hesitar, de desacelerar as soluções que se pretendem mágicas. É habitar as situações nos seus nós a partir de perspectivas determinadas; é agir também, engajar-se em ações e fabulações e narrativas que promovam, sem nenhuma garantia, a abertura para a possibilidade de getting on together. A aliança entre a ASP e a FCCO, assim como seu trabalho na ilha de Hayden, parece uma história desse tipo. Sallinger, em entrevista a Marra, discorda dos detratores que acusam a ASP de, ao abraçar a estratégia de C.E.D., ter "cedido" aos gatos (é curioso imaginar se o entrevistador não teria acreditado que seu entrevistado fora enfeitiçado pela gataria internacional que age como as petroleiras e a indústria do tabaco):

Acredito que estejamos trabalhando diretamente no problema. Não estou dizendo que sabemos o melhor modo de lidar com o problema da predação felina aqui em Portland. Mas estamos tentando algo diferente ao colaborar com a FCCO de um modo totalmente transparente (Sallinger apud Marra e Santella, 2016, p. 2583).

Esse parece um exemplo de bruxaria cosmopolítica, eficaz, não definitiva, experimental e corporificada. Melhor para os gatos, as aves, os moradores, voluntários e profissionais envolvidos. A morte não foi suspensa, uma arrogância desse tipo é inimaginável dentro das práticas aqui descritas; mas ela pode ser, quem sabe, melhor distribuída. Esse é um dos modos de habitar o problema.

33 “Companheiros não precedem a relação; o mundo é um verbo, ou pelo menos um gerúndio; mundificação é a dinâmica da intra-ação [...] e intra-paciência, o dar e o receber da modelação, até o fim, com consequências para quem vive e para quem morre e como" (Haraway, 2011, p. 10). 
Afinal, já que estamos falando de feitiçaria, não nos esqueçamos da aliança atávica entre os gatos e as bruxas ${ }^{34}$.

\section{9. \\ Fim de uma colônia}

Em dezembro de 2015, uma amiga veterinária me enviou uma mensagem pelo WhatsApp pedindo ajuda em relação a um caso que ocorria perto de onde moramos. Em uma casa que por um bocado de tempo ficou abandonada, formara-se uma colônia de gatos; esta casa dava para uma rua muito movimentada, ladeada por dois prédios. Minha amiga andava alimentando os gatos, que eram cerca de dez, mas viajaria dentro de alguns dias e se preocupava com a situação deles. À mensagem vinha anexado um vídeo no qual ela os mostrava: eram quase todos filhotes, e ela conseguia oferecer ração a eles por entre as grades - a casa vivia trancada, sem possibilidade de acesso ao quintal, e os gatos eram muito ariscos. Prontifiquei-me a assumir, por ela, aquele mínimo de apoio; e durante uma semana, mais ou menos, fui diariamente até a casa levar água e comida àqueles bichinhos que ali viviam sitiados.

À medida que os dias passavam, mais pessoas acabaram se envolvendo, curiosamente uma maioria de mulheres. Uma vizinha se compadeceu dos animais

34 A aproximação entre gatos e bruxas é tão pervasiva que chega ao ponto do clichê. Federici comenta sobre os diabretes ou familiares, animais que seriam ligados a elas, que esse avizinhamento "sugere que as mulheres estavam em uma (escorregadia) encruzilhada entre homens e animais, e que não apenas a sexualidade feminina, mas a feminilidade ela mesma assemelhava-se à animalidade. Para selar esta equação, as bruxas eram muitas vezes acusadas de mudar suas formas e metamorfosear-se em animais" (Federici, 2004, p. 194). Em The Great Cat Massacre, o historiador Robert Darnton diz, a respeito das torturas a que os gatos eram submetidos no começo da modernidade na Europa que, "antes de tudo, gatos sugerem bruxaria. Cruzar com um à noite em virtualmente qualquer esquina da França era se arriscar a se deparar com o demônio ou um de seus agentes ou com uma bruxa em um desígnio maligno [...] Bruxas transformavam-se em gatos de modo a jogar feitiços em suas vítimas. Às vezes, especialmente durante o Mardi Gras, elas se encontravam em hediondos sabás à noite. Uivavam, brigavam e copulavam horrivelmente sob a direção do próprio diabo na forma de um enorme gato. Para se proteger da feitiçaria dos gatos, havia um remédio clássico: mutilar um gato. Ao arrancar seu rabo, cortar suas orelhas, esmagar uma de suas pernas, arrancar ou atear fogo a seu pelo, quebrar-se-ia seu poder malevolente. Um gato mutilado não poderia ir a um sabá ou deambular para lançar feitiços. Camponeses frequentemente golpeavam gatos que cruzavam seu caminho à noite e descobriam no dia seguinte que machucados haviam aparecido em mulheres que se acreditava serem bruxas - ou pelo menos era isso que dizia a tradição em seu vilarejo. Aldeões também contavam histórias de criadores que encontravam gatos estranhos no celeiro e quebravam seus membros para salvar o gado. Invariavelmente um membro quebrado aparecia em uma mulher suspeita na manhã seguinte" (Darnton, 1999, p. 92-94). De certo modo essa associação perdura atualmente na figura popular da crazy catlady, a mulher louca cheia gatos, bruxa velha que vive só e rodeada por felinos. 
e passou a alimentá-los nos dias em que minha amiga, já de volta, não podia. Uma outra mulher, também veterinária e com conexões no setor da prefeitura que dizia respeito aos animais, passou a nos ajudar. Queríamos, todas, auxílio para capturálos e castrá-los e para tanto precisávamos de alguma assistência oficial - afinal, a casa era propriedade privada. Mas logo surgiu um complicador: uma obra começou a ser feita ali, anunciando que o lugar voltaria a ser habitado por humanos. Enquanto isso, nós frequentávamos a calçada diante da casa, onde passávamos algum tempo todos os dias brincando com os gatos e alimentando-os, e não demorou para conhecermos a proprietária: ela nos disse que não tinha nem queria ter nada a ver com os gatos, que os queria fora dali, mas não quis cooperar permitindo que arapucas ("gatoeiras") fossem colocadas em sua propriedade. Depois de um tempo, sequer nos atendia.

Eu e minha amiga conseguimos capturar a gatinha mais sociável de toda a colônia, a primeira que sempre vinha receber as pessoas que lhes levavam alimento. Ela era de pelagem preta, parecia ter cerca de seis meses de idade, uma feia infecção respiratória e a barriga grande, como se grávida. Nós a pegamos em um tipo de impulso e a levamos a uma consulta particular, já que a prefeitura não tomou nenhuma iniciativa, ocupada que estava com casos de colônias muito maiores e em condições mais precárias. Descobriu-se que na verdade ela era adulta, pequena apenas por desnutrição, e sua barriga aumentada era devido à alimentação reforçada a que tivera acesso naquelas últimas semanas. A infecção respiratória, entretanto, era grave. Foram dois meses de internação muito custosos - a ela, que foi arrancada de junto dos seus e passou esse tempo em uma gaiola, e a nós, que arcávamos com a parte monetária. No auge desta situação, chegamos a usar um site daqueles que permitem doações e montamos uma vaquinha; muitos amigos e conhecidos felizmente nos ajudaram e pudemos continuar com o tratamento da gatinha. Não consegui, porém, me livrar de certos pensamentos que me assombravam: se ela era adulta e havia vivido de algum modo até aquela idade (cerca de seis anos), não teria sido melhor que ficasse na casa, com seus parentes/povo/grupo/aldeia? E os gatos que ficaram lá e tinham nela sua líder, que espécie de ruptura eu e minha amiga havíamos causado em sua organização social? Que direito nós tínhamos de desfazer o arranjo precário mas de certa forma fluente que havia entre aqueles animais? 
A gatinha preta viveu em dois hospitais diferentes e passou por uma série de procedimentos de ordem respiratória e bucal até ser adotada pela veterinária que tinha contatos na prefeitura. Hoje vive com ela, o namorado e mais dois gatos. Há alguns meses foi diagnosticada com FELV, leucemia viral felina. Nunca fui capaz de responder definitivamente a nenhuma daquelas perguntas que eu própria me fazia.

Enquanto isso, os gatos permaneciam na casa, a obra chegava perto do fim e a prefeitura não tinha como ajudar. Um dia, um funcionário realmente dedicado mas também resignado me explicou que mal havia verba e interesse político ou social para cuidar dos humanos em situação de rua e me pediu para imaginar como seria a situação de recursos para animais que não eram sequer silvestres. Ele então nos emprestou uma gatoeira e isso foi tudo o que conseguimos com essas negociações. A saída da gatinha da casa realmente causara um rearranjo ali, mas, além disso, o estresse da obra e outros fatores desconhecidos por nós faziam com que a colônia diminuísse. Dois ou três filhotes bem pequenos um dia pararam de vir se alimentar; imagino que não tenham sobrevivido, os problemas respiratórios ali abundavam. A verdade é que a convivência de nosso pequeno grupo também começava a se esgarçar e a ficar conflituosa. Diferenças de opinião sobre os gatos, sobre a vida em geral, a frustração diante de uma situação que não se resolvia, a quantidade de dinheiro despendida, tudo isso concorria para que, cada vez mais, nossa relação se complicasse. À certa altura houve uma discussão enorme, e bem embasada de ambos os lados, sobre o destino que deveria ser dado aos gatos: capturá-los, esterilizá-los e devolvê-los ou capturá-los, esterilizá-los e doá-los? A devolução os colocaria de novo em território inimigo; era possível também devolvê-los a outro lugar, mais amistoso. Um funcionário da prefeitura nos ofereceu levá-los para o centro da cidade, para uma praça muito movimentada e com alguns pequenos canteiros onde eles "trabalhariam" caçando ratos. Declinamos dessa oferta. Doá-los deveria ser colocá-los em ambientes controlados, casas de pessoas que os quisessem, onde viveriam mais bem cuidados, apesar do espaço reduzido. Parecia uma saída boa, não fosse a dificuldade de encontrar pessoas que queiram receber animais de rua. No meio de toda essa discussão, a vizinha passou a capturar ela mesma os gatos, levá-los para esterilizar e vacinar e os mantinha em gaiolas, onde aguardavam adoção. Neste 
momento, nossa aliança se desfez. Não se conseguia chegar a nenhum consenso e além disso fui acometida por problemas de saúde.

A última notícia que tive não foi tanto dos animais quanto da casa; contaram-me que não havia mais gatos lá. Espero fortemente que todos tenham encontrado um lugar fora de gaiolas e que tenham conseguido estabelecer novos laços, com novas pessoas ou animais. Não duvido de que, dada a oportunidade, isso tenha acontecido. Minha parca experiência com animais de rua me mostrou que são extremamente tenazes e capazes de refazer suas vidas.

Às vezes, quando voltava da casa, tirava toda a minha roupa, punha-a na máquina de lavar e corria para tomar um banho, com medo de contaminar os gatos que vivem comigo com alguma doença desconhecida que pudesse haver entre os gatinhos da colônia, que sobreviviam como podiam e faziam daquele espaço um mundo. Há um tempo tomei a decisão de não trazer mais gatos para o apartamento onde moro; o espaço não é grande, não poderia lhes dar uma boa vida. Nesses dias, eu saía do banho e abraçava Bruxo, Nausicaa e Batatinha, melancólica diante dos errantes mas também alegre de poder ter respondido a esses três. Eles, como sempre, depois de um tempo, protestavam contra os abraços; preferem tomar a iniciativa do contato, não gostam de ter seus movimentos restringidos. Aquiescendo, eu os soltava. À noite, então, subiam em minha cama, aninhavam-se próximos de mim e caíamos juntos no sono, cada um povoado por seus próprios sonhos.

Então, o que é política? É um modo de intra-ação do qual resultam não apenas sujeitos, mas espaços coabitados; é abrir-se às intrusões do fora; é sair das dualidades que articulam seus termos por denegação e hierarquização; é coconstituir mundos conjuntamente, por entrelaçamentos situados; é dar voz a quem historicamente não a teve e examinar os próprios olhos; é cosmopolítica; é um tipo de feitiçaria cósmica que, ao transformar locais de habitação, visa transformar modos de habitar; é arriscar-se em arranjos provisórios; é compreender que tudo isso pode ainda falhar e começar de novo. 


\section{3 \\ Confinados}

Monkeys upon a tree never are very blue

They never seem to be under par that is true

Not like the ones you see on a bar in the zoo

Monkeys upon a tree do the Monkey Doodle Doo.

Irving Berlin, "Monkey Doodle-Doo"

\section{1. \\ De Monkey Islands e paradoxos}

Quando o etólogo e primatólogo Frans de Waal lançou Chimpanzee Politics. Power and Sex Among Apes, em 1982, seu emprego da palavra "política" para se referir à comunidade de chimpanzés encontrou, segundo ele mesmo conta, pouca ou nenhuma objeção entre os cientistas políticos; um deles, entretanto, Glendon Schubert ${ }^{35}$, "propôs que o termo 'política' fosse reservado para processos dentro de grupos de pelo menos cem indivíduos sem relações de parentesco" (de Waal, 1989, p. 16,1). Uma tal "reserva", de Waal nota, não apenas exclui a maioria dos animais outros que humanos e incontáveis situações sociais humanas da política

35 Schubert dedicava-se a estudos de comportamento judicial e, no fim dos anos 1970, realizou pesquisas em laboratórios de zoologia para encontrar o que supunha ser sua base biológica. Em 1991 ele editou, com Roger D. Masters, o livro Primate Politics, com textos de de Waal, Jane Goodall, Thelma Rowell, Shirley Strum e Bruno Latour, entre outros. Em seu artigo, Schubert argumenta que, assim como o comportamento familiar não é estudado por cientistas políticos, mas por sociólogos, só seria possível falar em um começo de política primata "quando as unidades de estrutura social tornam-se grandes o suficiente para abranger muitas subunidades consanguíneas (família estendida) em cooperação ou competição umas com as outras pelo controle das políticas [policies] que são importantes para o grupo em geral" (Schubert e Masters, 1991, p. 52). Nesse sentido, o autor parece se aproximar de Aristóteles, que diferenciava economia de política, a primeira dizendo respeito à casa e a segunda, ao Estado - o que, estranhamente, situa a escravidão fora da esfera política. Ele também adere a uma ideia evolucionista (e primitivista, além de etnocêntrica, por não considerar diferentes sociedades humanas) de política que vai do bando até o Estado; o "nível" de complexidade das sociedades primatas, segundo essa classificação, seria então o mesmo dos humanos de 100 mil anos atrás. A questão do primitivismo será tratada mais adiante. Schubert conclui com uma exortação do exame comparativo interespécies, tomando o comportamento político humano como modelo e ápice: "é mais provável que primatólogos e cientistas políticos descubram um solo comum para seu interesse mútuo na gênese - e epigênese [...] - do comportamento político através do uso mais consciente da teoria da evolução, de modo a manter suas observações etológicas em uma perspectiva melhor" (idem, p. 56). 
ao impor a esta critérios arbitrários, mas também se enfileira "na história da comparação símios-humanos" como mais um exemplo da série de "mudanças ad hoc [...] feitas na definição de um fenômeno de modo a excluir dados de primatas" (idem). Como lembra o primatólogo, o mesmo aconteceu quando o paleontólogo Louis Leakey, ao ler sobre as observações de Jane Goodall a respeito do uso de ferramentas por chimpanzés, lançou o desafio: "os cientistas que se apegam a esta definição [do humano como homo faber] são confrontados com três escolhas: devem aceitar os chimpanzés como homens, devem redefinir o homem ou redefinir ferramentas" (Leakey apud de Waal, 2016, p. 78); é claro que os cientistas prontamente recusaram a primeira opção ${ }^{36}$.

No caso de de Waal, foi de brincadeira, após horas de pé observando os chimpanzés por entre as grades de ferro que o separavam da colônia do zoológico de Burgers, em Arnhem, na Holanda, que ele começou a se referir ao "desenvolvimento" (idem, p. 12,6) desta última como política. Isso que começou de forma lúdica acabou se tornando uma hipótese séria quando, algumas páginas depois, "política" passa a ser definida nos termos do cientista político Harold Lasswell, como "um processo social que determina 'quem obtém o quê, quando e como", o que, tanto em humanos como em "seus parentes mais próximos [...], envolve blefe, coalizões e táticas de isolamento" (idem, p. 16,1). Chimpanzee Politics foi escrito a partir das observações do primatólogo a respeito da colônia de chimpanzés do zoológico de Burgers. O espaço desta colônia, estabelecida em $1971,{ }^{37}$ compreende uma ilha de 0.7 hectare rodeada por um fosso - chimpanzés

36 O cientista político John Rodman cunhou o termo "imperativo diferencial" para descrever esta tendência comportamental: "Todas as variações sobre o tema da virtude humana seja ela articulada como a habilidade de pensar, falar, conhecer a justiça, escolher, conhecer e adorar Deus ou (muito mais tarde) de criar tecnologias - estão enraizadas na pressuposição formal de que, pelo menos no nível da espécie, alguém torna-se melhor ao maximizar as differentia espécie-específicas. Para dizê-lo de modo mais forte, as diferenças entre espécies devem ser maximizadas, e o humano mais virtuoso é aquele que de modo mais completo transcende sua natureza animal e vegetativa. A existência de uma pressuposição paradigmática de status axiomático é demonstrada pela tendência quase universal dos autores clássicos mainstream, tanto pagãos como cristãos, de presumir o Imperativo Diferencial como autoevidente [...]" (Rodman, 1980 , p. 54).

${ }^{37}$ A famosa colônia foi parar nos noticiários mundiais em 2015 quando uma das fêmeas, Tushi, nascida ali em 1992, derrubou com um pedaço de pau um drone que filmava a ilha. Um estudo identificou o uso de 13 ferramentas pelos chimpanzés de Arnhem, sem que isso jamais lhes tenha sido ensinado - ainda que pudessem observar de longe os humanos que visitam o zoológico, além de seus funcionários. Um filme de 1984, The family of chimps, mostra os animais atirando pedras em um falso leopardo colocado lá para testar sua reação, além de usando um toco de madeira para alcançar as folhas mais altas de uma árvore. $\mathrm{O}$ filme foi mostrado aos chimpanzés no ano seguinte e, segundo o site do zoológico, "todos os chimpanzés assistiram às imagens em silêncio completo. Pareciam muito interessados. Alguns tinham suas orelhas eretas. Quando, no 
não sabem nadar - na qual há um terreiro de areia, grama, arbustos e árvores grandes. Cordas e estruturas de madeira compõem o enriquecimento ambiental; para as árvores maiores, entretanto, há uma cerca eletrificada que impede a predação pelos chimpanzés. Toda manhã, por volta das 09h30min, os símios são soltos neste espaço; à noite, são levados para jaulas, onde são alimentados pela manhã, antes de retornarem para a ilha. $\mathrm{O}$ fosso separa os animais dos visitantes do zoológico, não permitindo que estes se aproximem demais da colônia, mas apenas a observem a uma distância aproximada de 20 metros. Segundo o site do zoológico,

A diferença mais importante entre a colônia de Arnhem e uma selvagem é, claro, o espaço. O recinto é espaçoso o suficiente para permitir aos indivíduos fugirem ou se retirarem para um canto quieto, mas todos os animais estão permanentemente dentro de uma distância auditiva e podem, de modo intencional ou não, se envolver em quaisquer das atividades dos outros. Uma consequência desta restrição de movimento é que as fêmeas de Arnhem parecem menos temerosas dos machos do que aquelas na natureza. Não é incomum ver uma fêmea solicitar e receber apoio de várias outras contra um dos machos.

Como não existe nenhuma comunidade vizinha, migrações e interações intercomunitárias são, claro, impossíveis. Dentro do grupo, entretanto, uma separação espacial de fato ocorre, e subgrupos temporários são formados e dissolvidos ${ }^{38}$.

Foi esta diferença, uma certa restrição espacial e o fato consequente de os animais estarem à vista o tempo todo, que possibilitou a novidade da pesquisa de de Waal, qual seja, um estudo minucioso das relações sociais e da política dos chimpanzés - políticas intrabando, já que não há contato com colônias vizinhas. Em seu habitat natural, sem essa restrição, é difícil acompanhar minúcias

filme, uma fêmea foi atacada por machos púberes, muitos guinchos [barks] indignados foram ouvidos, mas era impossível dizer se os chimpanzés de fato reconheceram os atores. Isto mudou quando Nikkie, que havia morrido um ano antes, apareceu. O macho adulto Dandy imediatamente mostrou seus dentes em um riso nervoso e correu gritando para o macho adulto Yeroen, seu maior rival à época. Ele abraçou Yeroen e literalmente sentou em seu colo. Yeroen também tinha um sorriso incerto em seu rosto. Não houve dúvidas de que os machos haviam reconhecido seu antigo líder e que a 'ressurreição' de Nikkie havia temporariamente transformado os rivais em parceiros de coalizão novamente" (http://chimpansee.homestead.com/Film.html). Sobre o golpe de Tushi no drone, cujo vídeo conta com mais de 3 milhões de visualizações no Youtube, van Hoof e Lukenaar sugerem que foi motivado por curiosidade - de fato, em seguida à queda, com a câmera ainda funcionando, é possível observar chimpanzés não identificados inspecionando-o por um tempo, antes de abandoná-lo no chão: "Há uma careta momentânea logo antes e durante o ato do golpe. O rosto está tenso, os dentes à mostra, mas não há retração dos cantos da boca como em uma cara de 'medo', o que teria sugerido que se tratava de um reflexo agonisticamente motivado. A coincidência precisa da careta facial com o golpe sugere que se trata tanto de um assertivo quanto determinado empenho de força, homólogo ao que humanos fazem em situações comparáveis" (van Hoof e Lukenaar, 2015, p. 291).

${ }^{38}$ http://chimpansee.homestead.com/arnhemzoo.html. 
relacionais, parte das quais ocorre em árvores ou mata fechada, longe do olhar dos primatólogos de campo: "eles não deixarão de notar os resultados das mudanças sociais, mas muitas vezes irão ignorar suas causas" (de Waal, 1989, p. 21,7). Por outro lado, em "condições degradantes" como jaulas menores e sem estímulos, como ocorre em grande parte dos zoológicos, os animais não fariam quase nada além de "ficar deitados se masturbando entediadamente, andando de um lado para o outro ou batendo suas costas ou mesmo suas cabeças ritmicamente contra a parede de sua jaula" (idem, p. 23,8). Confinados em sua ilha, com alguma inspiração e pouca interação humana - além de uma proporção maior de fêmeas -, os chimpanzés de Arnhem proveram a matéria necessária para que de Waal pudesse com sucesso descrever e interpretar seu comportamento como político.

Foi também em um zoológico, e diante de primatas outros que humanos, que Gregory Bateson foi procurar, para a pesquisa que veio a se tornar o artigo "A Theory of Play and Fantasy", de meados dos anos 1950, "os critérios comportamentais que indicariam se um dado organismo está ou não apto a reconhecer que os signos [signs] emitidos por ele e por outros membros da espécie são sinais [signals]" (Bateson, 2000, p. 179). Bateson estava interessado na questão da comunicação verbal humana e postulava a possibilidade de ela sempre ocorrer em níveis abstratos contrastantes, dos quais dois são apresentadas logo no início do artigo a partir da análise da simples frase denotativa "“o gato está no tapete": o primeiro, metalinguística, do tipo "“a palavra gato não tem pelo nem morde"”, e o segundo, metacomunicativo, como em "“eu lhe dizer onde estava o gato foi um ato amistoso' ou "isto é brincadeira"” (idem, p. 178). A metalinguística teria como objeto a própria linguagem; a metacomunicativa, a relação entre os interlocutores. Para Bateson, o reconhecimento de que "signos de humor" [mood-signs] podem ser sinais - e assim, passíveis de ser "objetos de confiança ou desconfiança, falsificação, denegação, correção e assim sucessivamente" (idem) - foi um passo fundamental na evolução da comunicação, ainda que não tenha se completado sequer entre os humanos, que muitas vezes respondem automaticamente, por exemplo, "a manchetes de jornal, como se esses estímulos fossem indicações-objetuais diretas de eventos em nosso ambiente em vez de sinais arranjados e transmitidos por criaturas tão complexamente motivadas como nós mesmos” (idem). Seguir-se-ia daí não apenas a invenção da linguagem entre os humanos, "mas também todas as complexidades de empatia, 
identificação, projeção e assim por diante", além da "possibilidade de se comunicar em uma multiplicidade de níveis" (idem, p. 179).

No cerne desta hipótese estão os macacos - Bateson, no artigo, não revela a que espécie pertenciam - que habitavam o zoológico Fleishhacker, atualmente zoológico de São Francisco, visitado pelo autor em janeiro de 1952. Que ele se refira aos animais como monkeys e não apes torna muito provável que tenha observado os macacos-aranha que viviam na Monkey Island [Ilha dos Macacos] do zoo. Inaugurada em 1937, a ilha era constituída por um pequeno monte de placas de concreto por entre as quais uma fonte de água jorrava, diante de um modesto terreiro sem nenhuma vegetação, rodeada por um fosso; um recinto cuja inspiração parece ter vindo de uma ficção científica sobre um cenário de terra devastada (cf. Girlich, 2009). Segundo declarou um funcionário a um repórter do jornal SF Weekly que fazia uma matéria sobre a demolição da ilha em 1995, quando inaugurada, ela era "state-of-the-art" (Boulware, 1995, s/p). Continua o jornalista:

Câmaras dentro das placas de concreto eram aquecidas por um sistema de circulação de ar, um design compartilhado pelas monkey islands nos zoológicos de Londres, Berlim e Milwaukee. Infelizmente, o design também dificultava a manutenção da limpeza, das doenças e parasitas em um nível mínimo e o isolamento de um animal doente. Drenagem, ventilação e aquecimento começaram a se deteriorar com os anos, assim como o próprio concreto (idem).

A Monkey Island do zoológico de São Francisco foi um projeto da WPA (Workers Progress Administration, mais tarde renomeada Workers Projects Administration), uma das agências do New Deal de Franklin D. Roosevelt, criada em 1935 com o propósito de empregar os milhões de trabalhadores deixados sem ocupação durante a Grande Depressão norte-americana. Enquanto durou, entre 1935 e 1943, a agência empregou 8,5 milhões de pessoas em obras públicas como estradas, hospitais, escolas, museus, mercados, zoológicos e jardins públicos (cf. Leighninger, 1996).

A ilha foi inicialmente projetada para a habitação de macacos rhesus, uma espécie "alternadamente arborícola e terrestre" (Timmins et alii, 2008) mas, segundo uma publicação do zoológico datada de 2009, “em 1946 eles foram substituídos por macacos-aranha - uma espécie arborícola" (Frankel, 2009, p. 11). Mais que uma espécie, macaco-aranha é a denominação comum dada a diversas espécies do gênero Ateles; um artigo de 1972 sobre a colônia leva-nos a presumir 
que os habitantes da Monkey Island a partir de 1946 pertenciam à espécie Ateles geoffroyi (cf. Klein e Klein, 1971), nativa de América Central e de partes do México e da Colômbia. Não nos foi possível, entretanto, identificar a qual das sete subespécies os indivíduos da colônia pertenciam. Estes macacos, que costumam "viajar e forragear nos níveis mais altos da floresta", "passar muito tempo no dossel das árvores e também usar as camadas medianas e inferiores, sendo raramente vistos no sub-bosque", têm a característica de "ser altamente suspensórios", "de, ao viajar, passar mais tempo pendurados em galhos, movendose por braquiação [...] e escalando [mais] do que andando e correndo de quatro" (Cuarón et alii, 2008), tiveram que se contentar ali com um ambiente árido e sem árvores. Apesar disso, segundo a publicação do zoológico, “cordas, escadas, sinos e pneus proporcionaram muitos lugares para eles se balançarem e brincarem" e, assim, "a colônia prosperou", chegando a "uma população de 60 indivíduos, similar em tamanho e demografia a uma tropa selvagem" (Frankel, 2009, p. 11).

Na época em que Bateson os observou, em 1952, a colônia, instalada na ilha havia 6 anos, não contava com esse número de indivíduos; segundo Klein e Klein (1971), em 1966, eram 45. Assim como uma série de outros animais, incluindo humanos e diversas espécies de insetos (cf. Couzin, 2006; Couzin e Laidre, 2009), as sociedades atelíneas são de tipo fissão-fusão, isto é, nelas grupos grandes dividem-se em subgrupos, sendo mais próximas, em termos de fluidez na formação e manutenção desses subgrupos, daquela dos chimpanzés (cf. Chapman; Wrangham e Chapman, 1995), a espécie observada por de Waal em Chimpanzee Politics. Embora pareça exagerado afirmar que os macacos-aranha do zoológico de São Francisco vivessem em "condições degradantes" como as encontradas em jaulas, podemos sugerir que, tomando como padrão seu comportamento no habitat natural e aquilo de que seus corpos de membros longos são capazes, a conjuntura da Monkey Island estava longe de lhes permitir a melhor expressão de seu modo de vida. Mesmo assim, Bateson pôde observá-los brincando ${ }^{39}$ :

${ }^{39}$ No artigo "Problems in Cetaceans and Other Mammalian Communication", de 1966, Bateson narra uma conversa que teve com F.G. Wood Jr. (então diretor do Marine Studios na Flórida, um oceanário no qual até hoje se pode nadar com golfinhos e onde os animais ainda vivem em piscinas), a respeito do comportamento de animais confinados em condições degradantes. Referindo-se a uma fêmea do gênero Tursiops que se mantinha por muito tempo imóvel ainda que machos a golpeassem pelo lado com suas nadadeiras, Wood Jr. disse acreditar "que uma das razões pelas quais eles [os cetáceos] não fazem muita coisa em cativeiro é estarem mortos de tédio a maior parte do tempo. Não há nada de muito interesse em seu ambiente no tanque, e eu gostaria de sugerir que temos que manipular seu cativeiro de modo muito mais hábil 
Vi dois jovens macacos brincando, i.e., engajados em uma sequência interativa cujas unidades de ação ou sinais eram similares mas não os mesmos que os do combate. Era evidente, mesmo para o observador humano, que a sequência como um todo não era de um combate, e que, para os participantes macacos, aquilo era um "não combate" (Bateson, 2000, p. 179).

Para o autor, as ações dos animais que brincavam se mordendo mas sem que suas mordidas significassem [stand for] mordidas de combate e cujos gestos eram de briga mas sem que estivessem brigando eram uma evidência da existência de metacomunicação entre eles, isto é, "da troca de sinais que carregariam a mensagem "isto é uma brincadeira" (idem). To stand for, ele argumenta, é "um sinônimo próximo de denotar" (idem, p. 180), a brincadeira podendo assim ser definida: "Estas ações em que agora nos engajamos não denotam aquilo que as ações que elas significariam denotariam" (idem). Ou, de modo menos abstrato, "a mordiscada lúdica [playful] denota a mordida, mas não denota o que seria denotado pela mordida" (idem). Também a relação mapa-território, tal como formulada pelo semanticista Alfred Korzibski - a saber, "o fato de que uma mensagem, de qualquer tipo, não consiste dos objetos que ela denota", sendo antes similar à relação que um mapa tem com seu território -, passaria, diz Bateson, pelo ato da brincadeira (idem). A originalidade desta interpretação está na postulação de que a "metacomunicação e/ou a metalinguagem" encontrariam na brincadeira $^{40}$ um nível pré-verbal, um "importante passo em [sua] evolução" (idem). A mordiscada lúdica, ainda, ao denotar uma mordida, é, nas palavras de Bateson, "ficcional ${ }^{41}$ ”: “não apenas os animais que brincam não significam [quite mean] aquilo que estão dizendo, mas também estão usualmente comunicando a respeito de algo que não existe" (idem, p. 182).

do que fazemos. [...] Cetáceos cativos são como macacos em jaulas. São altamente inteligentes e altamente desenvolvidos e entediados" (Bateson, 2000, p. 377). Para imagens e uma discussão sobre o comportamento catatônico de cetáceos confinados, cf. o filme Blackfish (Cowperthwaite, 2013).

${ }^{40}$ Bateson fala também na ameaça (em que certos gestos denotam uma ação em um futuro possível, mas não no momento em que são realizados) e no comportamento histriônico ou no embuste (a imitação de um signo de humor, por exemplo) como formando, junto à brincadeira, um "complexo único total de fenômenos" relacionados à "ocorrência primitiva da diferenciação mapaterritório" (Bateson, 2000, p. 181). Em um nível que o autor defere à humanidade, certos rituais também são localizados neste "campo geral no qual a discriminação é traçada, mas não completamente, entre ação denotativa e aquilo que é denotado" (idem, p. 182).

41 Brian Massumi afirma, neste mesmo sentido, que a linguagem humana "seria essencialmente animal, do ponto de vista das capacidades lúdicas que carrega, tão intimamente vinculada com seus poderes metalinguísticos [...] Deleuze e Guattari não insistiam que é na escrita que o homem 'devém-animal' de modo mais intenso, isto é, entra mais intensamente em uma zona de indiscernibilidade com sua própria animalidade?” (Massumi, 2014, p. 8). A relação entre animalidade e literatura e o devir-animal serão tratadas no capítulo 4. 
A mensagem "isto é brincadeira", continua o autor, também cria um "enquadre paradoxal" (idem, p. 184) semelhante ao paradoxo de Epimênides, o célebre enunciado, proferido por um cretense, de que "todos os cretenses são mentirosos". O exemplo proposto no artigo é este:

Todos os enunciados dentro deste quadro são inverdades.

Eu te amo.

Eu te odeio.

(idem). A primeira afirmação do conjunto acima é causa de um "non-sequitur" (idem). Ela informa que, se todos os enunciados dentro do quadrado são inverdades, ela mesma é uma inverdade; e se ela é uma inverdade, aquilo que ela afirma é verdadeiro e portanto ela é falsa, em um movimento circular. Os outros dois enunciados então ficam ligados a esse primeiro, indecididamente verdadeiros e falsos; mas Bateson lembra que, mesmo que o primeiro enunciado seja de fato falso, ainda resta a possibilidade de que algum dos outros também o seja. Isto porque, da falsidade de "Todos os enunciados dentro deste quadrado são inverdades" pode tanto se seguir que "Nenhum dos enunciados é falso", ou seja, "ambos são verdadeiros", como que "Algum dos enunciados não é falso", ou seja, "um é falso e o outro é verdadeiro" - compreensão possibilitada pela distinção entre "alguns" e "todos", além de "nenhum" e "nem todos" que, segundo o autor, pareceria impossível para o "pensamento inconsciente ou '[de] processoprimário"” (idem), ocorrendo apenas em "processos mentais mais elevados ou mais conscientes, que servem no indivíduo não-psicótico para corrigir o pensamento em branco e preto dos níveis mais baixos" (idem). O pensamento primário, entretanto, continuaria sempre operando, sendo inclusive o responsável pela "validade psicológica do enquadre paradoxal da brincadeira" (idem, p. 185). Mas Bateson é categórico: embora esse processo primário siga operando, a diferenciação entre brincadeira e não-brincadeira é "uma função do processo secundário, ou 'ego"” (idem): "nos processos primários, mapa e território são equiparados; nos processos secundários, podem ser discriminados. Na brincadeira, ambos são equiparados e discriminados" (idem). A brincadeira, assim, marca um "passo adiante na evolução da comunicação" (idem). 
Há ainda uma outra questão a ressaltar no quadro proposto, o fato de que um de seus termos, o primeiro, é considerado ao mesmo tempo como premissa (de si mesmo e dos outros dois) e parte do conjunto, um problema lógico (já que um conjunto não poderia conter a si mesmo como um de seus elementos), o que leva o autor a considerar as noções de enquadre (frame) e contexto. Bateson observa que "o conceito psicológico [de enquadre] que estamos tentando definir não é nem físico [como no caso da moldura de um quadro] nem lógico" (idem, p. 187). O enquadre psicológico agiria de modo exclusivo ("ao incluir certas mensagens dentro de um enquadre [...] algumas outras são excluídas", idem) e inclusivo (“ao excluir certas mensagens, algumas outras podem ser incluídas”, idem), além de participar do "sistema de premissas" (idem) ao informar que se deve tomar o que está dentro dele de modo diferente do que aquilo que está fora, sendo uma espécie de mensagem metacomunicativa. Um enquadre pode ser ainda duplicado, como no exemplo dado pelo autor de pinturas dentro das quais há figuras delineadas, separando-as do que, por esse processo, passa a ser fundo. Este tipo de enquadre seria exigido como um modo de apaziguar possíveis paradoxos, chamados por Bateson de "paradoxos da abstração" (idem, p. 189), mas acabariam eles mesmos precipitando seus próprios paradoxos. A imagem proposta para ilustrar esse tipo de paradoxo é a do "conjunto de caixas de fósforos":

Quando uma classe lógica ou conjunto de itens é definido, [...] é necessário delimitar o conjunto de itens que devem ser excluídos, neste caso, todas as coisas que não são caixas de fósforos. Mas os itens a serem incluídos no conjunto de fundo [background set] devem ser do mesmo grau de abstração, i.e., do mesmo "tipo lógico" daqueles dentro do conjunto ele mesmo. Especificamente, se se quer evitar o paradoxo, a "classe das caixas de fósforos" e a "classe das não-caixas de fósforos" (ainda que ambos os itens claramente não sejam caixas de fósforos) não devem ser consideradas como membros da classe de não-caixas de fósforos. Nenhuma classe pode ser membro dela mesma. A moldura de um quadro, então, porque delimita um fundo, é aqui considerada como uma representação externa de um tipo muito especial e importante de enquadre psicológico - a saber, um enquadre cuja função é delimitar um tipo lógico. Isto, de fato, é o que era indicado acima quando se dizia que a moldura do quadro era uma instrução para o espectador de que ele não deveria estender as premissas válidas entre as figuras dentro do quadro para o papel de parede atrás dele.

Mas é precisamente este tipo de enquadre que gera um paradoxo. A regra para evitar paradoxos diz que os itens fora de qualquer linha delimitadora devem ser do mesmo tipo lógico daqueles dentro dela, mas a moldura do quadro, como analisado acima, é uma linha que divide itens de um tipo lógico daqueles de outro. Russell insiste que os itens de tipos lógicos inapropriados devem ser excluídos (i.e., por uma linha imaginária) do fundo de qualquer classe, ou seja, ele insiste que se deve desenhar uma linha imaginária precisamente do mesmo tipo que ele proíbe (idem, p. 189). 
Retornando aos animais, Bateson conclui dessa discussão que há três tipos de mensagens em seu comportamento: i. sinais de humor; ii. "mensagens que simulam sinais de humor" (idem); e iii. "mensagens que permitem ao receptor discriminar entre sinais de humor e aqueles outros sinais que se parecem com eles" (idem). A mensagem contida na brincadeira pertenceria a este último tipo e possibilitaria o surgimento de paradoxos na medida em que "é uma tentativa de discriminar ou desenhar uma linha entre categorias de diferentes tipos lógicos" (idem, p. 190). Mas, para ele, ao contrário do que pensa Russell, tais paradoxos não constituem erros de comunicação, sendo antes os motores mesmos de seu desenvolvimento:

[...] acreditamos que os paradoxos da abstração devem manifestar-se em todas as comunicações mais complexas que aquelas dos sinais de humor e que, sem estes paradoxos, a evolução da comunicação chegaria ao fim. A vida seria então um interminável intercâmbio de mensagens estilizadas, um jogo com regras rígidas, sem nenhum alívio trazido pela mudança ou pelo humor (idem, p. 193).

A partir daí o autor segue procurando articular sistemas relacionais de mensagens ao comportamento humano tal como encontrado e abordado pela psicoterapia; ele aventa a possibilidade de que algumas psicopatologias seriam desencadeadas justamente por um fracasso na lida com relações de enquadre e fundo e seus paradoxos ${ }^{42}$ - e a função da psicoterapia, assim, seria a de transformar os "hábitos metacomunicativos dos pacientes" (idem, p. 191), atuando como um jogo cujas regras vão mudando à medida que se joga, isto é, com o tipo lógico do discurso se alterando. Tratar-se-ia de "um sistema de interação em evolução" como aquele da "brincadeira de filhotes de gato ou lontras" (idem, p. 192).

42 Assim, “'a salada de palavras' da esquizofrenia pode ser descrita em termos do fracasso do paciente em reconhecer a natureza metafórica de suas fantasias. No que deveriam ser constelações triádicas de mensagens, a mensagem que estabelece o enquadre (por exemplo, na frase, 'como se') é omitida, e a metáfora da fantasia é narrada e realizada de uma maneira que seria apropriada se a fantasia fosse uma mensagem de um tipo mais direto. [...] Com a perda da habilidade de estabelecer enquadres metacomunicativos, há também uma perda da habilidade de alcançar a mensagem mais primária ou primitiva. A metáfora é tratada como uma mensagem de primeiro tipo" (Bateson, 2000, p. 190-191). 


\section{2.}

\section{Soberania e patologia}

Este artigo de Bateson é fundamental para a construção dos argumentos encontrados no livro do filósofo Brian Massumi What Animals Teach us About

\section{Politics (2014), no qual o autor afirma ter como intenção}

visualizar uma política diferente, que não seja uma política humana do animal, mas uma política integralmente animal, livre dos paradigmas tradicionais do sórdido estado de natureza e suas pressuposições associadas a respeito do instinto, que permeiam tantas facetas do pensamento moderno (Massumi, 2014, p. 2).

Massumi nota, no segundo suplemento de sua obra, intitulado "A zoologia da brincadeira", que embora Bateson se dedique longamente a discussões sobre "brincadeira, reflexividade e linguagem", ele deixa de lado, demasiado rapidamente, a cena do zoológico, como se "o animal e sua relação evolutiva com o humano pudessem ser simplesmente denotadas, a presença do observador humano distraidamente submetida a um apagamento" (idem, p. 65). É sobre esse observador, portanto, que o autor então se debruça, mais exatamente sobre a posição de espectador (spectatorship) em um zoológico.

Um espectador humano em um zoológico, Massumi assevera, não pode ser rapidamente apagado das narrativas que são produzidas sobre os animais ali observados. Sua proposta para escapar de uma possível acusação de correlacionismo ${ }^{43}$ é herdada de uma espécie de linhagem filosófica que remonta a "Bergson, Whitehead, Deleuze, Ruyer e Simondon (para não mencionar Pierce)",

43 Massumi dedica uma longa nota às estratégias anticorrelacionistas de Quentin Meillassoux e Graham Harman; sobre o primeiro, a ideia de que "o pensamento tem um acesso direto especulativo ao real" é vista como uma volta a um entendimento "altamente tradicional da filosofia", que atribui ao "raciocínio lógico-matemático" "uma vocação universal" (Massumi, 2014, p. 113); sobre Harman, o alvo da crítica é a recuperação de uma outra noção tradicional, a distinção entre qualidades primárias e secundárias, e sua subsequente atribuição das últimas, historicamente pertencentes aos sujeitos, aos objetos. Ao criar, por essa manobra, objetos-em-si em perpétuo duelo com suas "múltiplas qualidades" mantidas no lugar por uma espécie de "“cola' mágica [...] que mantém o universo unido" (idem), chamada metáfora, Harman se veria imerso em uma série sem fim de problemas causados em última análise pelas "pressuposições fundantes do [seu] empreendimento: a necessidade de uma ontologia baseada na substância e a ideia de que o objeto é essencialmente retirado [withdrawn]" (idem, p. 114). Massumi segue criticando o projeto da Ontologia Orientada a Objetos com base na questão da posição: "A falsidade dos problemas é traída pelo uso conspícuo do 'nós' quando se trata de dar conta da percepção e da relação. Que 'nós' é esse? O 'nós' permanece genérico. O ‘nós' genérico é sempre um sinal certo de um sujeito implícito: uma colocação entre parênteses do ato de pensamento à medida que ele ocorre. Devemos 'nós' realmente acreditar que chegar por caminhos intrincadamente tortuosos de volta ao sujeito genérico humano, agora apoiando a retórica de uma metafísica orientada-ao-objeto, é um avanço filosófico? Devemos 'nós', sujeitos implícitos, hipotecar nossa atividade de pensamentoação à metáfora? Anestesiar com éter [etherize] nossos devires relacionais? Que política é essa?' (idem). 
autores que teriam sido capazes de "dar conta da presença do humano e ao mesmo tempo respeitar a autonomia ontogenética do não-humano, reconhecendo a realidade plena do que jaz para além do humano". Massumi postula que "o problema não é pensar o objeto sem o humano", mas pensar a "implicação do humano em uma realidade que por natureza o ultrapassa. O problema é o maisque-humano [...]" (idem, p. 114).

Por princípio, Massumi localiza a humanidade em um "continuum animal" (idem, p. 3) no qual a grande questão seria a da "inclusão mútua" dos termos, "a articulação do modo de inclusão do humano no animal e do animal no humano" (idem, p. 65). Mas o autor aponta também a possível arbitrariedade na escolha desse continuum animal como foco ou meio por onde sua pesquisa se movimenta, quando nem a animalidade nem a vida em geral "podem ser estritamente diferenciadas do não-orgânico ${ }^{44 "}$ (Massumi, 2014, p. 52) e a "lógica da inclusão mútua" não permitiria excluir todos esses outros universos. Ele figura essa decisão como uma espécie de "começo pelo meio", ao modo de Deleuze e Guattari: se na natureza só há misturas, os limites são virtuais e os "polos de movimentos tendenciais são ideais", então os "continua de combinação tendencial são mais convenientemente agarrados pelo meio" (idem). Nesse sentido, o continuum da natureza poderia ser chamado de continuum das plantas - "ou da criatividade, ou da consciência, ou do instinto, ou da vida, ou mesmo da matéria (redefinida de modo a não ser mutuamente excludente dos anteriormente citados ou do virtual)" (idem), "dependendo de que meio se escolhe para começar" (idem). Começar por quaisquer desses meios, ele continua, "terá consequências para o modo como todos os conceitos filosóficos envolvidos se desenvolverão [play out] e para sua relação uns com os outros" (idem, p. 53). Nesta prática reside um método filosófico, a saber, que "a coerência do continuum conceitual deve ser integralmente reinventada a cada recomeço, de modo que a própria filosofia seja

44 Para uma discussão acerca da oposição entre vida e não-vida e suas consequências biopolíticas, cf. Povinelli, 2016. A antropóloga Elizabeth Povinelli nota como há uma articulação entre ciências humanas e naturais que têm consequências diretas para a vida de povos indígenas cujas cosmologias não contêm a oposição entre orgânico e inorgânico - principalmente em sua relação com os Estados nacionais em termos políticos, como, por exemplo, nas decisões sobre quais entes importam ou não na demarcação e conservação de terras ou nas relações entre populações e territórios: "o Imaginário do Carbono é o espaço homólogo criado quando os conceitos de nascimento, crescimento/reprodução e morte são revestidos em conceitos de evento, conatus/affectus e finitude [...]. Ele procura, itera e dramatiza o fosso entre Vida e aquilo que é concebido como anterior ou sem Vida" (Povinelli, 2016, p. 760). 
uma emergência contínua de variação” (idem, p. 52-53). Mas por que então o continuum animal? Por um motivo "simples e crucial" (idem, p. 52): ele permite que a discussão se dê muito facilmente em torno da questão da brincadeira, que vai ser fundamental para o encadeamento de certos conceitos com vistas a uma discussão política.

Retornando ao evento do zoológico, Bateson, como sugere Massumi, teria deixado de considerar a natureza dos enquadres em jogo e sua posição neles enquanto observador. Ao olhar os macacos enjaulados - ou, como vimos mais acima, em ilhas de macacos - a partir da posição de observador não-implicado, ao situar-se fora e além de qualquer relação com aqueles animais, o autor inadvertidamente reforçaria uma "operação rigidamente excludente" (idem, p. 65). Os enquadres, ele dizia, são mutuamente exclusivos e inclusivos e funcionam como premissas metacomunicativas. Ora, o desafio que Massumi coloca é o de levar adiante a teoria de Bateson e aplicá-la à própria experiência desencadeadora de seu pensamento sobre a brincadeira, qual seja, a (não)-relação entre humanosobservadores e animais-enjaulados no espaço de um zoológico. Qual é a mensagem metacomunicativa que algo tão concreto como grades de ferro passam? Qual é a relação entre figura e fundo em uma exibição de animais cativos diante de humanos? Dentro dos recintos, Massumi responde, encontra-se a natureza; do lado de fora, a cultura. Os animais em exposição em um zoológico proveem o pano de fundo - que é visto, mas com o qual qualquer interação de mão dupla é interditada - para os sujeitos humanos. As grades, cercas, jaulas, telas de metal são o enquadre concreto que informa: daqui para dentro, a animalidade; daqui para fora, a humanidade. Trata-se assim de um procedimento de "exclusão por inclusão", a animalidade contida dentro do mundo humano significando aquilo que ele não é:

Este enquadramento [framing] zoológico repete o gesto que Agamben identifica como o gesto fundante da política humana. O animal é reduzido ao estado de "zoé", mera vida biológica sob o governo categórico das leis da natureza e, consequentemente, excluído da pólis (ou, mais precisamente, incluído para ser excluído). Os espectadores humanos gozam do estatuto de "bíos": "a forma ou modo de vida próprios de um indivíduo ou grupo"; uma "vida qualificada", reconhecida como pessoa e dotada do estatuto jurídico que acompanha esse reconhecimento (personalidade moral) (Massumi, 2014, p. 66-67).

O enquadre zoológico não produziria nenhum tipo de paradoxo produtivo, mas apenas um paradoxo de tipo estéril, a "zona de indistinção" tal como 
exprimiu Agamben, de que tratamos no capítulo anterior. A relação de um recinto com seu entorno, Massumi segue, estabelece um duplo enquadre que é "uma dupla oposição: humano versus animal e humano-versus-animal versus indiferenciação" (idem, p. 68). Todas as diferenças ou zonas de indiscernibilidade são negadas em favor de oposições e trata-se da emergência mesma da soberania, "quando à exclusão incluída é dada uma figura [...] na forma paradoxal da exceção que funda a regra, reconstituindo o governo no ato de suspendê-lo" (idem). O zoológico seria assim "um exercício de soberania humana face a face com o animal" (idem). As palavras de Agamben na introdução de Homo Sacer: O poder soberano e a vida nua ganham, diante da jaula de um zoológico, uma repentina materialidade:

É necessário, antes de mais, perguntar-se por que a política ocidental se constitui primeiramente através de uma exclusão (que é, na mesma medida, uma implicação) da vida nua [...] uma exclusão inclusiva (uma exceptio) da zoé na pólis, quase como se a política fosse o lugar em que o viver deve se transformar em viver bem, e aquilo que deve ser politizado fosse desde sempre a vida nua. A vida nua tem, na política ocidental, este singular privilégio de ser aquilo sobre cuja exclusão se funda a cidade dos homens (Agamben, 2002, p. 15).

A soberania obedece a uma lógica de paradoxo cuja formulação Agamben encontra em Carl Schmitt, jurista e teórico político que se envolveu com o Terceiro Reich: “o soberano está, ao mesmo tempo, dentro e fora do ordenamento jurídico, [...] ele permanece fora do ordenamento jurídico e, todavia, pertence a este, porque cabe a ele decidir se a constituição in toto pode ser suspensa" (Schmitt apud Agamben, 2002, p. 23). Tal paradoxo parece pertencer àquele tipo exposto por Bateson: o soberano é o enquadre do ordenamento jurídico ao mesmo tempo que um de seus membros; entretanto, argumenta Massumi, ele é "estéril, apesar de ser constitutivo" (Massumi, 2014, p, 68), pois o paradoxo soberano nunca cria nada além de uma zona de indistinção entre o ordenamento e o estado de exceção e da exclusão inclusiva da vida nua, "o núcleo original, ainda que oculto, do poder soberano" (Agamben, 2002, p. 14). Este paradoxo, assim, "não inventa, refunda. Não ultrapassa o dado, o dá de novo" (Massumi, 2014, p, 68) e, sendo assim, não poderia operar como aqueles que, como observava Bateson, são indispensáveis para a evolução da comunicação. A "estrutura soberana da política humana" (Massumi, 2014, p. 69), assim, ao barrar os fluxos dos paradoxos da abstração por duplos enquadres que criam zonas de indistinção e impossibilitam a diferença, é "anti-devir" (idem). Mais que isso, continua Massumi, "na medida em 
que a vida e sua evolução criativa são uma só, a política humana é anti-vida" (idem).

A aproximação entre a teoria da brincadeira de Bateson e a da soberania de Agamben permitem ainda a Massumi desenvolver conceitualmente os caracteres anti-devir e anti-vida da política humana como patologias:

Todos os três componentes da política humana - a figura do humano, o fundo animal contra o qual ela se destaca e a zona de indiferença explorada pelo estado de exceção através do qual esta diferença estrutural é suspensa - podem ser considerados patológicos de acordo com os critérios de Bateson (Massumi, 2014, p. 69).

São identificados assim diversos comportamentos "político-patológicos" (idem, p. 70): o neurótico ou normopata, que fortifica os limites contra qualquer possibilidade de paradoxo ou indiscernibilidade (combate ou brincadeira); o paranoico ou psicótico, que não consegue diferenciar o que é do que poderia ser, no qual "o signo é seriamente tomado como aquilo que denotaria” (idem) (tudo é combate); e o sociopata, "a pedra angular da exceção soberana" (idem, p. 71), o próprio fundamento da soberania, considerada por Massumi como um comportamento patológico transindividual "que opera para refundar a estrutura da política humana de modo a retransmitir mais normopatia e psicose em seu infernal anti-devir complementar" (idem). A sociopatia, pelo movimento soberano que funda a política humana, então, estabelece e retroalimenta seus caracteres neuróticos e paranoicos; neste sentido, todos os regimes soberanos são sociopatas. Uma patologia transindividual ou trans-situacional, ela pode no entanto se fixar individualmente, por exemplo "pela força da privatização [ou pela] suspensão do campo relacional da animalidade (e mesmo de seu substituto humano atrofiado, a esfera pública)" (idem, p. 72).

O zoológico, na medida em que oferece uma visão clara das patologias da política humana mantidas de pé pelo mecanismo soberano, emerge como um modelo. Uma certa "pessoalização" dos animais ali presentes - a quem se nomeia e sobre quem narrativas infantilizadas são contadas - cria uma espécie de zona de indistinção entre o que é bíos e o que é zoé, como se aos seres ali aprisionados de repente fosse concedida uma "vida qualificada". Essa zona de indistinção a princípio pareceria estar em desacordo com a neurose da hiperseparação, aproximando-se da indiferenciação psicótica; entretanto, ela não é senão uma articulação entre as duas patologias, tendo em vista que se forma unilateralmente, 
na forma de uma projeção humana sobre a vida dos animais cativos dotados de características antropomorfas de um mau tipo. Em outras palavras, os animais tornam-se "pessoas" no zoológico por uma operação na qual suas especificidades comportamentais e fisiológicas são negadas em favor de uma identificação com instituições humanas: romances, celebração de feriados, aniversários, nascimentos e também de substituições de animais mortos como se fossem novos parentes em alegre visita. Trata-se assim de uma indiferenciação que nega a agência dos animais, seu estado de cativos e as particularidades de cada espécie em favor de uma identificação que é uma imposição ao mesmo tempo psicótica (uma confusão indistinta entre animais e humanos) e neurótica (a determinação de categorias inflexíveis: o romance, o aniversário, o feriado, os comportamentos adequados) (cf. Massumi, 2014).

\section{3.}

\section{"Algo que foi tornado absolutamente marginal"}

John Berger afirmou, sobre as visitas a zoológicos, que durante elas "você está olhando para algo que foi tornado absolutamente marginal" (Berger, 2009, p. 34) e que nessas instalações os animais não são senão "monumentos vivos de seu próprio desaparecimento" (idem, p. 36). Ao zoológico, ele diz, vai-se só: o animal não olha de volta, roubado da centralidade de sua vida. Os recintos, por melhores que sejam, não fazem senão emular de modo pobre e em espaço reduzido, além de esvaziado de outras espécies, aquilo que seria o seu território; subtraídos de seu mundo e com o mundo subtraído de si, sem recursos ou agência, os animais tornam-se dependentes de seus cuidadores e constituem-se como criaturas eternamente à espera do que sucederá a eles: alimentação, visitas médicas, a algazarra de visitantes diante dos quais passam a vida expostos. O autor afirma ainda que, apesar de não querer fazer dos zoológicos um símbolo, eles "têm algo em comum" com "todos os sítios de marginalização forçada guetos, favelas, prisões, manicômios, campos de concentração" (Berger, 2009, p. 36).

O ensaio aqui citado, "Why look at animals?", publicado em 1980, é dedicado a Gilles Aillaud, um dos principais pintores da chamada Nova Figuração, movimento surgido no começo dos anos 1960, centrado na 
reivindicação da figura contra o que se percebia como esgotamento da pintura abstrata. Aillaud volta-se, ainda nessa década, para os animais presos em zoológicos; muitas de suas pinturas mostram cenas das jaulas e recintos dessas instituições, jamais o público. Nelas veem-se animais por entre grades em espaços assépticos, como em Orang-Outang derrière la grille (1965) ou Cage aux lions (1967), na qual dois jovens leões repousam sobre prateleiras, única mobília de sua jaula. Em Serpent et trou (1966), uma serpente rodeada de três paredes maciças é vista em um espaço mínimo com um pequeno buraco no meio. Piscine vide (1974) mostra uma piscina de ladrilhos totalmente vazia atrás da qual, a ela ligada por uma escada escura, há um pequeno platô cercado por grades de ferro onde jaz a figura disforme de um hipopótamo. Na maior parte de suas pinturas, os animais não nos olham; leões têm as cabeças voltadas para as paredes de sua jaula, ursos vivendo numa fossa dão as costas ao espectador ou miram um tronco baixo, um jacaré albino de mandíbula aberta é visto de lado, encarando grades azuis. Talvez em apenas uma delas, a do orangotango, o animal, retratado quase no quarto inferior da tela, com apenas um pouco mais que a cabeça visível, olha para fora de sua cela árida em direção ao espectador (ou ao espaço livre, o aberto?) enquanto segura as barras de metal com sua mão esquerda. A pose parece reforçar sua posição de cativo e se assemelha à de presos humanos pelo gesto manual. Os historiadores Éric Baratay e Élisabeth Hardouin-Fugier comentam, em Zoos: Histoire des jardins zoologiques en Occident (XVI-XX siècle), a propósito de Piscine Vide, mas também de Serpent, porte et mosaique (1972), na qual uma serpente no fundo de seu recinto se confunde com a textura da parede, e de Lion (1971), onde “o leão é uma rocha” (Baratay e Hardouin-Fugier, 1998, p. 238), que Aillaud "apresenta os animais reduzidos a elementos de decoração" (idem).

Os dois historiadores situam o pintor em uma onda crítica aos jardins zoológicos surgida durante os anos 1960 no contexto de lutas anticapitalistas, anticolonialistas e contra o confinamento, da qual fizeram parte também o biólogo inglês Desmond Morris, o psicanalista canadense Henri Ellenberger e o jornalista italiano especializado em prisões e etologia Emilio Sanna, entre outros. Para Morris, os zoológicos eram condenáveis como uma versão reduzida da própria cidade: em ambos os espaços, haveria epidemias de patologias nervosas causadas pela alienação. Ellenberger vê nos zoológicos uma versão do hospital psiquiátrico; Sanna os considera como "um elemento do universo concentracionário (com as 
prisões e os hospícios) criado pelas sociedades modernas" (Baratay e HardouinFugier, 1998, p. 236), celebrando melhorias no regime de confinamento animal como sendo paralelas a avanços sociais como a diminuição da segregação e o regime de liberdade condicional. ${ }^{45}$

Mesmo antes da institucionalização dos zoológicos, quando havia apenas ménageries (coleções de animais), estas foram alvo de duros ataques durante o Iluminismo por causa dos gastos vistos como exorbitantes para a sua manutenção; há um verbete com este nome na Enciclopédia de Diderot e d'Alembert que é categórico: "é preciso destruir as ménageries quando às pessoas falta pão; seria vergonhoso nutrir bichos com gastos altos quando ao nosso redor homens passam fome" (Diderot e D'Alembert, 1765, p. 330). No curto texto, antes de exprimir seu juízo, o autor ainda menciona que "cabe praticamente apenas aos soberanos" têlas (idem), estabelecendo uma ligação entre soberania e propriedade de coleções animais. Após a Revolução Francesa, a questão bifurcou-se em duas: por um lado, prefigurando o movimento dos anos 1960, as ménageries passaram a ser vistas como símbolos da servidão humana, sendo de suma importância libertar seus presos; por outro, urgia-se que os animais fosem domesticados e se tornassem úteis à nação, "como alegorias de cidadãos laboriosos" (Baratay e HardouinFugier, 1998, p. 102) - isto é, que fossem, de certa forma, assimilados, tornados

\footnotetext{
${ }^{45}$ Baratay e Hardouin-Fugier comentam que, por uma "especificidade intelectual francesa", a questão encontrou pouco eco no país e que mesmo "um Michel Foucault, filósofo das prisões, da clínica e da loucura, não se interroga sobre o zoológico" (idem, p. 237). Na verdade, embora não participe da crítica aos zoológicos, Foucault faz uma menção, em Surveiller et Punir, que, apesar de breve, é poderosa, ao insinuar uma relação entre o panóptico e as coleções reais de animais: "Bentham não diz se foi inspirado, em seu projeto, pela ménagerie que Le Vaux construíra em Versalhes, primeira ménagerie na qual os diferentes elementos não são, como era tradição, disseminados em um parque: no centro, um pavilhão octogonal que, no primeiro estágio, incluía apenas uma peça, o salão do rei; todos os lados se abriam por grandes janelas sobre sete jaulas (o último lado era reservado à entrada) onde estavam presas diferentes espécies de animais. Na época de Bentham, essa ménagerie não existia mais. Mas encontramos no programa do Panóptico o cuidado análogo da observação individualizante, da caracterização e da classificação, do ordenamento analítico do espaço. O Panóptico é uma ménagerie real; o animal é substituído pelo homem, o agrupamento específico pela distribuição individual e o rei pelo maquinário de um poder furtivo" (Foucault, 1975, p. 204-205). Há ainda uma outra aparição dos jardins zoológicos, mais enigmática, na obra foucaultiana; em "Des espaces autres", conferência de 1967, o filósofo dá como um exemplo de heterotopia lugares que são "espécies de contraposicionamentos [...] nas quais os posicionamentos reais [...] estão ao mesmo tempo representados, contestados e invertidos" (Foucault, 2001, p. 1574). Os jardins surgem aí como um dos tipos mais antigos de heterotopia: "o jardim é a menor parcela do mundo e também a totalidade do mundo. O jardim é, desde o fundo da Antiguidade, um tipo de heterotopia feliz e universalizante (donde nossos jardins zoológicos)" (idem, p. 1578). Não fica claro, na passagem, o sujeito dessa felicidade. Embora o filósofo tenha feito referência a zoológicos essas duas vezes, no fim das contas ele realmente não voltou sua atenção aos animais lá expostos. A ménagerie não é senão matriz do Panóptico e o verdadeiro problema está no encarceramento, controle e punição dos homens.
} 
parte da sociedade civil, cosmopolitas. Uma espécie de amálgama das duas bandeiras surgiu e foram criados jardins e museus de história natural para o acolhimento, a domesticação e o estudo dos animais em nome da ciência e da nação - o cativeiro deixa assim de ser considerado escravidão por ganhar utilidade ao cumprir propósitos civis.

Desde o seu surgimento, os zoológicos gozam de uma ambígua vocação, sendo lugares de entretenimento saudável e instrutivo para os cidadãos, de estudos científicos e símbolos de grandeza nacional ${ }^{46}$ - não se pode esquecer o contexto colonialista de seu desenvolvimento. Por todo o século XIX, são os "empreendedores da colonização" (idem, p. 114) que fornecem animais selvagens e exóticos aos jardins emergentes:

À época em que a Europa constituía um imenso império colonial, quatro modos de apropriação do animal exótico se desenvolvem. A apropriação mais radical, a caça, ganha muitas vezes um movimento heroico, em particular para os militares coloniais, que aumentam seu prestígio purgando o país de sua fauna. A limitação espacial imposta ao animal, o zoológico, se confunde frequentemente com a aclimatação. A apropriação psicológica, enfim, em particular aquela das feras pela domesticação, está bem de acordo com a abordagem colonial tornada alegoria da escravidão pelos caricaturistas e é a um domador que Lyautey confia o Zoo de la Coloniale, vitrine do imperialismo triunfante. Em constante interferência, a caça, o zoológico, a aclimatação e a domesticação suscitam uma demanda que agita o sucesso crescente das exibições de animais, mas também a mortalidade que dizima os bichos (Baratay e Hardouin-Fugier, 1998, p. 131).

Durante este mesmo período, exibições itinerantes de animais e pessoas considerados exóticos se instauram em zoológicos europeus: "milhões de espectadores irrompem diante desses homens e bichos estranhos, todos confundidos pela denominação de "selvagens"” (idem).

${ }^{46} \mathrm{O}$ primeiro jardim zoológico do Brasil foi inaugurado em 1888, mesmo ano da abolição da escravidão, no bairro de Vila Isabel, no Rio de Janeiro. Era propriedade do Barão Drummond que, na petição inicial enviada à Câmara Municipal da Corte, em 1884, afirmava desejar "dotar esta capital com um Jardim zoológico, há muito reclamado como necessidade à capital do Império não só como motivo de embelezamento, mas principalmente pelos elementos de estudo que tal estabelecimento proporcionará" (Drummond apud Magalhães, 2005, p. 24), e fazia a requisição de 30 anos de monopólio, além de isenção de impostos. A Câmara lhe concedeu as isenções e 25 anos de privilégio, fazendo algumas requisições, entre elas, que os animais fossem distribuídos e instalados de acordo "com as prescrições higiênicas aconselhadas pela ciência" (Magalhães, 2005, p. 27). O Barão Drummond viria ainda a, em 1892, inventar o jogo do bicho: os bilhetes de entrada ao jardim podiam conter 25 figuras de bichos estampados. Diariamente, uma caixa posicionada a três metros de altura na entrada do zoológico era aberta e o bicho vencedor anunciado: aqueles que possuíam um bilhete com a mesma figura eram contemplados com um prêmio em dinheiro. Diz-se que o jogo do bicho causou um grande frisson social antes de sair do zoológico para as ruas em 1895, quando foi posto na ilegalidade. O primeiro bicho sorteado, em 3 de julho de 1892, foi a avestruz (cf. Magalhães, 2005). 


\section{4.}

\section{"Tristes filósofos"}

Nos empreendimentos coloniais, o número de animais mortos para a captura de um vivo, em geral filhote, era enorme, já que era preciso matar as fêmeas cuidadoras e muitas vezes o chefe do bando para se ganhar acesso ao pequeno. Carl Hagenbeck, comerciante alemão de animais exóticos celebrado como o criador do zoológico moderno (além de famoso por suas exibições de humanos), afirmava-se "'muitas vezes obrigado a matar' os elefantes que protegiam seus descendentes com a muralha de seus corpos" (idem, p. 132). O transporte até o destino, longo e precário, com os animais alojados em péssimas condições, era causa de muitas outras baixas. Considerados "mercadoria colonial" (idem, p. 136), animais feridos e desidratados eram abandonados pelo caminho com membros gangrenados, outros eram embalados, e o mesmo Hagenbeck conta sobre um elefante de quase uma tonelada e meia que passou os 40 dias de viagem até a Europa "sem banho nem nutrição" (idem, p. 137). Apesar disso, e embora comerciantes calculassem que metade dos animais perecesse durante o transporte ${ }^{47}$, a quantidade de exemplares que chegava ao destino é impressionante: Baratay e Hardouin-Fugier contam que entre 1866 e 1886, apenas Hagenbeck

exportou cerca de 700 leopardos, mil leões e 400 tigres [...] mil ursos; 800 hienas; 300 elefantes; 70 rinocerontes da Índia, de Java e de Sumatra e 9 da África; 300 camelos; 150 girafas; 600 antílopes, dezenas de milhares de macacos; milhares de crocodilos, milhares de boas e pítons [...] e muito mais de 100 mil pássaros (idem, p. 138).

Tampouco é de espantar que a maioria dos animais não sobrevivesse muito tempo após sua chegada aos zoológicos - sendo rapidamente substituídos por novos indivíduos, em um ciclo infernal. Em 1908, o zoólogo alemão Alexander Sokolowsky, membro honorário do Instituto Internacional de Psicologia Zoológica de Paris, publicou Beobachtungen über die Psyche der Menschenaffen (Observações sobre a psique dos grandes primatas), em uma tentativa de

\footnotetext{
${ }^{47}$ Os historiadores observam que não foi senão em 1948 que dois zoológicos, o de Anvers e o de Copenhagen, começaram a transportar animais por via aérea (cf. idem, p. 138). Quanto à mortalidade, Jean Yves Domalain, captor de animais atuante na segunda metade do século XX e autor do livro de memórias Fui traficante de feras, estima em "dez o número de animais mortos para cada um visível no zoológico"; Baratay e Hardouin-Fugier lembram ainda que "entre 1988 e 1991 a taxa de mortalidade [...] para os babuínos e os Macaca fasciculares [espécie muito usada em laboratórios de pesquisa] da África [foi] de 10 a 37\%; das Filipinas, em torno de 10\%; da Indonésia, de 18 a 54\%" (idem, p. 139).
} 
compreender as vidas anímicas de chimpanzés, gorilas e orangotangos - e responder à pergunta sobre suas mortes rápidas nos zoológicos. Ele conta ter podido observar oito gorilas adolescentes, com a idade variando entre 6 e 8 anos, no Hagenbecks Tierpark, em Hamburgo, que "desde o primeiro momento de sua chegada [...] manifestaram total apatia em relação a seu entorno [...] reticentes e tímidos, afastavam-se dos homens assim que estes se aproximavam" (Sokolowsky, 1908, p. 18). Diferentemente dos "alegres filhotes de chimpanzés, [os gorilas] manifestavam desamparo e angústia de um modo indiscutível" (idem), apresentavam uma "expressão de melancolia e tristeza" (idem) e "sentavam-se quietos sem se importar com mais ninguém e assim no máximo mexiam uma palha” (idem, p. 20). Quanto à aproximação forçada e uma possível agressividade, Sokolowsky observa que "embora os gorilas evitassem angustiadamente qualquer contato por parte dos humanos e mordessem imediatamente caso se usasse de violência para tocá-los, eles jamais tentavam um ataque e nunca tomavam uma posição ameaçadora" (idem, p. 19); pelo contrário, "portavam-se como cativos, resignados a seu destino", ainda que recusassem "reticentes qualquer aproximação de seu agressor" (idem). Os animais só se moviam para comer as bananas que lhes eram atiradas dentro da jaula ao se perceberem sozinhos e imediatamente retomavam sua atitude apática caso se vissem na presença de humanos, mesmo de seus cuidadores.

Esses jovens gorilas sobreviveram apenas poucos dias, após o que foram encontrados, como diversos outros em distintas ocasiões, caídos sobre o chão de sua jaula com o rosto virado para baixo. Sokolowsky contesta os diagnósticos correntes que identificavam as causas dessas mortes a alterações de clima e nutrição inadequada. Para o zoólogo, tais razões eram secundárias e o trágico fim dos gorilas cativos se devia a "influências anímicas que minavam" (idem, p. 21) sua saúde. Desprovidos de sua "energia vital [...] na alegria da plena liberdade" (idem), os animais só podiam definhar. Em uma frase, a causa principal de sua morte estava na incapacidade de "superar a perda da liberdade" (idem, p. 18), o que Sokolowsky pretende resolver com a sugestão da aquisição de gorilas ainda mais jovens, que "conheceram a vida na liberdade apenas em pequena medida [e] se estabelecerão mais facilmente em novas relações do que são capazes os exemplares mais velhos, que se encontravam no usufruto da plena liberdade" (idem, p. 22). 
Ainda que Sokolowsky descreva seus gorilas como "tristes filósofos", na expressão utilizada pelo historiador Nigel Rothfels em Savages and Beasts: The Birth of the Modern Zoo, Baratay e Hardouin-Fugier observam que não foi senão nos anos 1960, com "o desenvolvimento do estudo de campo" (Baratay e Hardouin-Fugier, 1998, p. 196), que os gorilas deixaram de ser representados como animais ferozes, modelos do famoso King Kong ${ }^{48}$. Rothfels compara o estudo de Sokolowsky com o relato de Paul du Chaillu, considerado o primeiro homem branco a matar um gorila, em 1855. Neste relato, o gorila assassinado é referido como "uma criatura de sonhos infernais, pertencente àquela ordem pavorosa, meio-homem, meio-bicho", "uma visão de pesadelo", possuindo "uma expressão facial infernal", "grandes e profundos olhos cinzas ferozmente inflamados" que, ao ser atingida pela bala fatal, soltou um "gemido que tinha algo de terrivelmente humano e ainda assim era pleno de bestialidade [brutishness] [e] caiu sobre a própria face ${ }^{49 ”}$ (du Chaillu apud Rothfels, 2012, p. 2). Esta ideia

${ }^{48}$ Esses estudos de campo com primatas outros que humanos foram feitos sobretudo por mulheres, primeiramente as chamadas "trimatas" de Louis Leakey, Jane Goodall, Dian Fossey e Birute Galdikas, e depois levados adiante por outras primatólogas de destaque, como Barbara Smuts, Shirley Strum e Thelma Rowell, entre outras. Pelo que está em jogo nas pesquisas, além da mudança na abordagem e a revolução causada nas narrativas sobre primatas com a entrada de mulheres no campo, Haraway afirma que a primatologia pode ser considerada um gênero de teoria feminista (cf. Haraway, 1991): "Em uma irônica reviravolta na lógica da vida e das ciências humanas, os corpos marcados tornam-se os corpos autoativadores: corpos fêmeas/colonizados/trabalhadores/animais tornam-se cidadãos e o escândalo requer transformação de teoria e práticas" (Haraway, 1991, p. 287); "Meu argumento tem vários fios. Primeiro, o feminismo europeu e euro-americano e a primatologia são ambos discursos ocidentais e sexualizados que herdam a estrutura lógica da apropriação hierárquica própria à autoformação do 'humano' (o 'homem' do ocidente). Segundo, teoria feminista e primatologia estão de modo sinergético profundamente implicadas na produção de biologia e antropologia, aqueles discursos nos quais tanto mulheres como homens foram objetos de conhecimento natural-técnicos cruciais. Terceiro, reconstruir as histórias técnicas e populares da primatologia é uma forma séria de prática feminista, e histórias são reconstruídas em elaboração com muitos tipos de apostas e práticas na vida social. E, finalmente, a primatologia muda os significados possíveis de muitos feminismos. Nem todas as práticas de mulheres são feministas e a prática de homens pode ser feminista. [...] Feminismo e primatologia são ambos ciência e política, produtoras de fato e ficção, disciplinas sociais e técnicas. São ambos práticas sociais para escrever histórias sobre quem 'nós' somos e para controlar fronteiras e estruturar campos para a aquisição de identidades" (idem).

${ }^{49}$ Não há como não lembrar, a respeito do gemido hibridamente humano e animal do gorila assassinado por du Chaillu, da observação feita por Hegel em lições de 1805-1806 e que constam do parágrafo 350 de sua enciclopédia, citada por Agamben em A linguagem e a morte: "Todo animal tem na morte violenta [im gewaltsamen Tode] uma voz, exprime a si mesmo como o si mesmo suprimido (als aufgehobenes Selbst)" (Hegel apud Agamben, 2006, p. 66). Sobre esta passagem, comentei em minha dissertação de mestrado, a respeito da leitura de Agamben, que "para Hegel, a voz animal, vazia, só deixa de sê-lo na morte violenta [...] Nenhum som, proferido por nenhum animal, em momento nenhum de sua vida, se aparenta[ria] a uma voz (um 'puro si') [...]. Mas, em sua morte (somente a violenta, é destacado), aquele grito e somente aquele seria uma expressão de si mesmo. A voz humana, 'voz da consciência', por sua vez, só poderia então começar aí. O animal, ao morrer, exprime um puro si suprimido; o humano, possuidor de uma linguagem articulada, guardaria então nela o traço do grito desse outro [...]. 'A linguagem humana 
sobre os gorilas ainda vicejava quando da publicação do livro de Sokolowsky, e sua presença nos zoológicos vinha atender a um desejo senhorial e colonialista: além de ser possível ver neles a terrível fera reduzida a um estado de impotência quase infantil, “a captura de animais era uma representação simbólica da conquista de terras distantes" (Berger, 2009, p. 31).

Dian Fossey, a terapeuta ocupacional que se tornou primatóloga por seu amor aos gorilas, primeira pessoa a desenvolver um trabalho de campo realmente extenso com a subespécie das montanhas - antes dela, o mais longo estudo desse tipo, de autoria do biólogo George Schaller contava pouco mais de um ano e algumas centenas de horas de observação - comenta em seu Gorillas in the Mist, de 1983, que se tratava de uma espécie "gentil e ainda difamada" (Fossey, 2000, p. xv). Chamam atenção em seu livro as contínuas referências à reciprocidade do olhar entre ela e seu grupo e os animais, o que mostra uma profunda diferença de relação entre esse tipo de estudo e as visitas ao zoológico; logo em seu primeiro encontro com um gorila, Fossey menciona que ele "nos olhou de volta [peered back at us]" (idem, p. 3); seus olhos são descritos como "brilhantes" e "lançados nervosamente sob pesadas sobrancelhas sobre nós como se procurasse nos identificar como amigos familiares ou possíveis inimigos" (idem). Quando o livro foi publicado, contavam-se cerca de 4000 gorilas na natureza, dos quais 240 das montanhas. A pesquisadora refere-se à drástica queda na população desses animais - metade em menos de dez anos - causada pela caça e pela diminuição de seu habitat, "apropriado para propósitos de cultivo" (idem, p. xviii), e explica que o argumento da conservação vinha sendo usado pelos defensores da manutenção de gorilas em zoológicos. Ela pondera então que, "por causa dos fortes laços de parentesco entre famílias de gorilas, a captura de um jovem gorila pode envolver a morte de muitos do seu grupo familiar" (idem, p. xviii), além do que "certamente nem todo animal capturado chega a seu destino vivo" (idem). Fossey prossegue argumentando que "três vezes mais gorilas foram retirados da natureza do que nasceram em cativeiro e [que] as mortes de gorilas em confinamento continuam ultrapassando os nascimentos" (idem). Em seguida ela sustenta, em nome da conservação, a necessidade de preservação dos habitats, elencando em seguida

(...) é a tumba da voz animal, que custodia e mantém fixa a sua essência mais própria (...): 'o Morto" (idem, p. 67). O humano começa onde o animal morre (violentamente)" (Fausto, 2012, p. 50). Nesse sentido, o assassinato do gorila por du Chaillu, o primeiro homem branco a realizar tal façanha, pode ser interpretado como uma cena fundante. 
uma série de considerações sobre as instalações de instituições que já mantinham exemplares da espécie, com vistas a uma substancial melhoria no alojamento dos animais no sentido de buscar uma maior semelhança com seus ambientes originais.

Fossey, que viveu mais de 18 anos com os gorilas das montanhas e foi brutalmente assassinada dois anos depois do lançamento de Gorillas in the Mist, conclui então não poder "concordar com aqueles que advogam pela salvação dos gorilas da extinção assassinando e capturando mais indivíduos livres apenas para exibi-los em confinamento" (idem). Embora haja gorilas (em sua imensa maioria, gorilas-ocidentais-de-terras-baixas, Gorilla gorilla gorilla) em programas bem sucedidos de reprodução em jardins zoológicos hoje, nenhum pertence à subespécie das montanhas. Ninguém jamais teve êxito, apesar de diversas tentativas, sobretudo entre os anos 1960 e 1970, em manter vivo um exemplar de Gorilla beringei beringei em confinamento (cf. IGCP, 2015).

O zoológico, às custas de inumeráveis vidas, veio realizar, simbólica e concretamente, o sonho do domínio da natureza pela cultura, confirmar um poder soberano de extensões imperiais, transformando grande parte da biota do mundo conhecido em vida nua. Acrescente-se a este complexo uma das mais poderosas frentes de sustentação do império, aquela que pode confirmar a sua ideologia ao mesmo tempo em que se reclama independente: a da produção de saber. "O argumento era de que [o zoológico] era outra forma de museu, cujo propósito era avançar o conhecimento e o esclarecimento públicos" (Berger, 2009, p. 31).

Carl Hagenbeck, referido anteriormente, foi responsável pela "revolução Hagenbeck", uma mudança na apresentação dos animais nos zoológicos, que deixaram de ser expostos atrás de grades, substituídas por fossos em ambientes "mais naturalistas" (Rothfels, 2002, p. 8) e, assim, muito mais visíveis ao público. Era criado, desse modo, o formato ilha (na maior parte das vezes de cimento) cercada por fosso, o mesmo utilizado na ilha dos macacos visitada por Bateson em 1952 e observada, ainda que com consideráveis mudanças, por de Waal nos anos 1970. Este modelo de recinto, ao permitir que os animais sejam observados de todos os lados, fornece um lugar privilegiado para o observador estudioso. Baratay e Hardouin-Fugier, entretanto, observam que, embora a separação por vala possa parecer eficaz, ela também apresenta perigos para a vida dos animais. No caso de paquidermes, por exemplo, a água não os impede de seguirem até as 
cercas afiadas que separam o fosso do público, muitas vezes em busca de lanches ou outras oferendas, e assim se ferirem, tropeçarem e até morrerem, como em um caso ocorrido em Lyon em 1998 (cf. Baratay e Hardouin-Fugier, 1998, p. 253). No caso de animais que não sabem nadar, como muitos primatas, o fosso representa o perigo de afogamento.

Foi o que aconteceu com Nikkie, um dos chimpanzés observados por de Waal em Chimpanzee Politics, comprado pelo zoológico aos dez anos de idade, até ali exibido em um espetáculo do tipo Holiday on Ice por seus donos anteriores, que se tornou o líder da colônia em 1977 por meio de uma coalizão com Yeoren, outro macho, e a mais velha das fêmeas, Mama, e morreu afogado em 1984 depois de perder seu posto. O chimpanzé, referido por de Waal como "extremamente brilhante" e "o mais rápido e acrobático do grupo" (de Waal, 1998, p. 103,4), perdeu o apoio de seu aliado Yeoren, que se associou a outro macho, Dandy, contra ele; provavelmente com medo de um ataque fatal - quatro anos antes, o próprio Nikkie, em conluio com Yeoren, havia assassinado um outro contendor ao lugar de líder, Luit -, ele tentou pular o fosso, feito que havia realizado com êxito "quase exatamente um ano antes" devido a "uma fina camada de gelo" (idem, p. 363,5), mas desta vez afundou na água, afogando-se. O etólogo Otto Adang, autor de um livro sobre a colônia chamado De machtigste chimpansee van Nederland (O Chimpanzé mais poderoso da Holanda), narrou em seu diário o dia da morte de Nikkie:

Março de 1984. Chego mais tarde do que costumo. Está estranhamente calmo. Nikkie não está com o resto do grupo no salão. Os estudantes não sabem me dizer onde ele se encontra. Quando vou procurá-lo, vejo a cuidadora Jacky Holmes andando pela ilha. Ela está toda molhada. "Ele está morto", ela soluça, e demora um tempo até eu compreender o que havia acontecido.

A manhã havia se tornado fria demais para que os chimpanzés saíssem, então Jacky os colocara em um dos salões. Nikkie recusara-se a entrar. Permaneceu no corredor, aparentemente ávido por acasalar com a fêmea sexualmente atraente Krom. O interesse ciumento por seu inchaço já havia causado muita agitação nos dias anteriores. Jacky decidiu deixar Krom em sua jaula noturna para lhe permitir algum descanso. Nikkie esperou em vão, mas recusou-se a entrar no salão ou a voltar para sua jaula. Quando, algumas horas depois, o sol começou a brilhar, Jacky resolveu deixar Nikkie sair e puxou a porta de correr do recinto. Imediatamente Nikkie correu para fora com toda a velocidade. Sem parar, de modo silencioso, cruzou toda a extensão da ilha, cerca de cem metros. Quando chegou ao fosso, pulou. Apesar de sua velocidade e da força de seu pulo, não conseguiu chegar ao outro lado. Afundou como um tijolo. Quando Jacky, em choque, corajosamente o puxou para fora do fosso alguns minutos depois, ele já havia morrido. Em vão, ela tentou fazer respiração boca a boca. Apenas para termos 
certeza, andamos em torno do corpo sem vida de Nikkie. Não há dúvida possível: o chimpanzé mais poderoso da Holanda está morto.

O resto do grupo ainda está dentro e não pôde ver o pulo fatal de Nikkie. Ainda assim, eles permanecem singularmente silenciosos. Os estudantes, que não sabiam sobre o destino de Nikkie, também perceberam. Nenhum som era ouvido, nem mesmo o grito de uma criança. De um modo ou de outro, eles haviam notado que algo peculiar acontecera. Claro que eles tinham escutado o som da porta de correr e de Nikkie saindo. Depois disso, devem ter escutado pessoas na ilha e sabiam que nunca havia pessoas e chimpanzés no recinto ao mesmo tempo. [...] Repetidas vezes explico o que realmente aconteceu. Um macho alfa, que só poderia ser o mais dominante cooperando com outro macho. Nada especial no que diz respeito a chimpanzés. Uma aliança que é quebrada. Nada especial também. Um rival conspirando com um antigo aliado. Até aqui uma história familiar. Na África, um macho alfa destronado evitaria seus rivais por um tempo e se retiraria para a periferia da área de sua comunidade. Isto não é possível em Arnhem, mas o passado mostrou que um antigo líder pode se adaptar à nova situação e permanecer no grupo sem problemas. Uma coincidência infeliz levou à situação na qual Nikkie deve ter se sentido extremamente ameaçado. A essa altura ele não procurou refúgio em uma árvore, como normalmente teria feito. Acho que, em um momento de pânico, ele tentou pular o fosso. Um ano antes tinha conseguido, então por que falharia desta vez? Quando Nikkie saiu, deve ter pensado que o resto do grupo o seguiria e poderia atacá-lo. Não há razão para supor que Nikkie tenha querido morrer. Ele não cometeu suicídio, mas realizou um pulo apavorado e desesperado. Queria chegar do outro lado, mas fracassou (Adang, 2016, s/p).

Nikkie não se suicidou, não quis morrer. Tinha medo, desejou ir embora, o que era proibido até no mais "naturalista" e cuidadoso dos zoológicos. É claro que ele poderia ter sido morto por outros chimpanzés se não vivesse em confinamento, mas foi este o detalhe definidor do seu destino, exemplo do que significa ser o animal mais poderoso no contexto de um jardim zoológico ${ }^{50}$. Do lado da ciência e da relação entre humanos e primatas outros que humanos, por sua vez, foi a observação rigorosa também da vida de Nikkie, seu comportamento, relações, alianças e traições, levada a cabo graças ao modelo ilha da colônia que habitou, o que permitiu a de Waal afirmar que os chimpanzés possuíam uma política, avançando questões sobre humanidade e animalidade, além de concorrer para uma transformação enriquecedora da imagem desses símios, com consequências para o modo como são percebidos e tratados. ${ }^{51}$

\footnotetext{
${ }^{50}$ A reação da colônia ao ver a imagem de Nikkie no filme The family of chimps é descrita na nota 1 deste capítulo.

${ }^{51}$ Alguns grupos de direitos animais têm lutado pelos direitos de grandes primatas, como sua soltura de zoológicos por habeas corpus. Em 2014, na Argentina, a orangotanga Sandra, então com 28 anos, conseguiu esse direito, mas a dificuldade de seu traslado e preocupações com sua adaptação impediram sua soltura, de modo que ela aparentemente segue vivendo sozinha em sua jaula (cf. http://www.infobae.com/sociedad/2017/03/23/la-orangutana-sandra-esta-deprimida-yaconsejan-trasladarla-a-brasil/). Em novembro de 2016, um outro habeas corpus foi concedido em favor de uma chimpanzé, desta vez, Cecilia, de cerca de 30 anos, que chegou ao santuário do braço brasileiro do GAP (Great Ape Project) em abril de 2017 (cf.
} 


\section{5.}

\section{"Aberrificação"}

Antes dos fossos, antes da revolução que transformou a vida dos animais em um espetáculo observável por todos os lados e pouco mais de cem anos antes da morte de Nikkie, em 1875, a cerca de 400 km de Arnhem na direção nordeste, Carl Hagenbeck estreava sua primeira exibição de humanos em Hamburgo. É bem verdade que esse tipo de exposição já havia ocorrido em muitas outras épocas e lugares, como durante o Império Romano, e havia se intensificado pelo menos desde a invasão da América. Montaigne mesmo teve a chance de conversar com tupinambás levados à França ainda no século XVI, encontro que resultou em seu célebre ensaio "Dos canibais." O trânsito era tamanho que "no meio do século XVI, os 'índios' 'haviam se tornado a maior atração de teatros e procissões" (Rothfels, 2002, p. 87). Entre as pessoas exibidas, havia aquelas que eram capturadas e levadas à força, como diversos inuit aprisionados pelo militar Martin Froshbier durante o século XVII e referidos por um de seus homens como "suas novas presas" (idem). Por todo o período do século XVIII ao XIX os espetáculos continuaram, o que levanta a pergunta sobre o interesse, quando exibições de humanos são referidas, por aquelas produzidas por Hagenbeck. Onde jazeriam as diferenças e peculiaridades dessas exibições? Rothfels levanta a hipótese da verossimilhança de costumes: os shows de Hagenbeck não mostrariam apenas pessoas, mas culturas, isto é, apresentariam comunidades em seu estado "autêntico", "puro", com artefatos e animais "legítimos"; comunidades que, segundo o relato do então produtor, sequer sabiam que eram matéria de espetáculo. Isto é, diferentemente de outras exibições anteriores e contemporâneas, Hagenbeck se destacaria por não enganar seu público com um falso embelezamento dos modos dos povos que oferecia como atração ou com

http://www.projetogap.org.br/noticia/chegou-cecilia/; a sentença em seu favor pode ser lida em https://portalseer.ufba.br/index.php/RBDA/article/view/20374). No Brasil, alguns outros processos desse tipo tramitaram na justiça, como a da chimpanzé Suiça, que faleceu no zoológico antes que seu destino fosse decidido (https://portalseer.ufba.br/index.php/RBDA/article/view/10259/7315), ou Jimmy, um chimpanzé pintor, que vive no zoológico de Niterói, no Rio de Janeiro, e teve o pedido negado por um desembargador, por não ser humano (cf. http://www1.tjrj.jus.br/gedcacheweb/default.aspx?UZIP=1\&GEDID=0004E164C7F5BA0C4F3C3 D56853A3CF5FD40D4C4212E3E3B). Embora de Waal seja um opositor da extensão de direitos a animais, seu trabalho é por vezes usado como justificativa para que estes lhes sejam concedidos (cf. $\quad$ https://www.utilitarian.net/singer/by/200605--.htm http://journals.lub.lu.se/index.php/pa/article/view/13756/13623). 
nativos por demais "civilizados", afirmando, ao contrário, prover-lhes uma peça quase científica.

Some-se a isso a ideia, cultivada a partir do século XVIII, com o surgimento das ciências humanas, de que os povos humanos ditos selvagens seriam primitivos - ou seja, que sua natureza não seria diferente da dos ocidentais, mas a mesma em estado primevo, antigo, como bem demonstra Hélène Clastres em "Primitivismo e ciência do homem no século XVIII":

É que a ciência do homem, em relação à qual se é unânime em reconhecer como a "mais útil", não tem em si mesma o seu fim: sua finalidade é moral e política; tratase de chegar, através do conhecimento de diversas sociedades, até aquela que pode coincidir finalmente com o Reino da Razão, onde os indivíduos poderão realizar o fim que lhes foi atribuído pela Natureza, a saber, a felicidade. Explicação científica e juízo de valor estão, pois, intimamente associados [...] (Clastres, 1980, p. 196).

A novidade do primitivismo estava na universalização do conceito de homem, subordinado a uma ideia de história unívoca. Povos não-ocidentais eram percebidos, assim, como uma fotografia do passado da humanidade, cuja história seguiria uma trajetória de sentido único até seu ápice com a civilização ocidental aquela que singularmente teria alcançado uma maturidade racional suficiente para o conhecimento sobre a própria história em sua universalidade. A publicação, ainda, em 1859, de On the Origin of Species, de Charles Darwin, que postulava, entre outras coisas, uma continuidade animal hierarquizada, terminou por estabelecer o contexto diante do qual as exibições de comunidades humanas primitivas "autênticas" em zoológicos e feiras puderam ser recebidas com entusiasmo na Europa, inclusive pela comunidade científica. Os espetáculos de Hagenbeck não se destinavam apenas aos espectadores ávidos por exotismo ou uma visão do passado, mas favoreciam o estudo de povos primitivos in loco, sem que fosse preciso se deslocar. O então presidente da Sociedade Berlinense de Antropologia, Etnologia e Pré-História, Rudolf Virchow, tornou-se um grande entusiasta do trabalho de Hagenbeck e chegou a referir-se a uma exibição de inuits em 1878 como "uma das cenas etnológicas mais interessantes que se desdobra diante de nossos olhos" (Virchow apud Rothfels, 2002, p. 92). As visitas que o jovem Franz Boas fez à exposição dos bellacoola (nuxalk) vindos do Canadá em 1886 renderam-lhe pelo menos três artigos publicados no mesmo ano (cf. Rothfels, 2002, p. 231). 
Virchow examinou os inuit de 1878, "Caspar Mikel Okabak (36); sua esposa, Juliane Maggak (24); seus dois filhos, Anne (2 1/2) e Katrine (13/4); e dois homens solteiros Hans Kokkik (41) and Heinrich Kujanje (28)” (idem, p. 93) com grande cuidado, mas se interessou mais por questões de fisiognomia, realizando toda sorte de medição de seus corpos, do que por seus costumes. Em seu caso e no de outros estudiosos, era como se os propalados modos autênticos dos povos expostos viessem apenas legitimá-los como bons corpos-objetos de pesquisa. Enquanto isso, shows de aberrações abundavam e suas atrações eram anunciadas ao público como "elos perdidos" entre o homem e o macaco; Krao Farini, uma menina nascida no Laos que sofria de hipertricose, foi exibida pelos Estados Unidos e pela Europa durante toda a sua vida, tendo sido mostrada no jardim zoológico de Frankfurt pelo menos em duas ocasiões: em 1884, ainda com 8 anos, e depois adolescente, em 1894; em uma de suas últimas fotos conhecidas, ela aparece no Congresso de Aberrações no Circo Ringling de 1924. Um folheto de 1887 a descreve como "a prova viva da teoria de Darwin sobre a descendência do homem" e explica que "o argumento usual contra a teoria darwinista de que o homem e o macaco têm um ancestral comum tem sido sempre o de que até hoje nenhum animal foi descoberto no estado de passagem entre macaco e homem"52, apresentando Krao como evidência desse estado. Ainda que neste caso as sociedades científicas não endossassem as declarações sensacionalistas, é interessante perceber o lugar que esses shows, junto com as exibições "etnológicas" de Hagenbeck, encontraram no imaginário e nas narrativas acerca da teoria da evolução. O próprio Virchow, por exemplo, depois de desmentir que um casal de irmãos com microcefalia, Bertola e Maximo, apresentados como astecas e como mais uma "prova" da evolução, de fato o fossem, os inclui em seu relatório anual à Sociedade de Antropologia de Berlim de 1891, embora com aspas, no rol de povos reais e não junto às pessoas com deformidade que tivera oportunidade de observar:

Aqui na sociedade vimos os Dualla de Camarões e Negros da costa oeste da África (que se chamam a si mesmos de Dahome), Melanésios e Tagalos, Lapões e "Astecas"; as mais fantásticas monstruosidades andaram à nossa frente: uma

52 Reprodução do folheto disponível em
https://en.wikipedia.org/wiki/Krao_Farini\#/media/File:Krao_The Missing_Link_Wellcome_L0047972.jpg 
indiana heteradélfica, italianos xifódimos, uma mulher barbada da América do

Norte [...] (Virchow apud Rothfels, 1996, p. 169).

Assim, como observa Rothfels, no contexto do frenesi a respeito das teorias darwinistas, os povos considerados exóticos passavam por processos de aberrificação.

“Tierra del Fuego", espetáculo que Hagenbeck apresentou em 1881, composto por "quatro homens, quatro mulheres e três crianças" (idem, p. 164), foi um sucesso estrondoso ao qual compareceram 50.000 pessoas em um só domingo em Paris e para o qual foi preciso erguer um palco alto no Jardim Zoológico de Berlim de modo a melhor ordenar a multidão. Ao tentar explicar o êxito do evento, o biógrafo de Hagenbeck argumentou que nele "era possível ver ainda o humano como ele [o público] o havia imaginado, empurrado de volta a um passado incalculável, no começo mesmo de sua existência como humano" (Leutemann apud Rothfels, 1996, p. 164). Nesta exibição não aconteciam performances e se conta que os fueguinos sentavam-se quietos a maior parte do tempo, movimentando-se apenas para preparar alimentos em uma fogueira. $\mathrm{O}$ editorial de um jornal alemão reprovou o evento, acusando seus produtores de bárbaros sem coração capazes de submeter aquelas pessoas a um show cujo significado não era certo que elas entendiam, o que colocaria em questão seu consentimento - se é que haviam consentido (cf. Rothfels, 2002, p. 96-97). Por outro lado, a Sociedade Antropológica de Berlim confirmou a "autenticidade" dos fueguinos e diversas publicações notaram neles “"frouxas estruturas sociais”, uma falta 'do sentimento da vergonha', métodos 'brutos' de preparação e cozimento dos alimentos e uma falta de padrões 'civilizados' de limpeza" (idem, 1996, p. 165), observações todas muito afins às de Darwin sobre o mesmo povo no encerramento de The Descent of Man, and Selection in Relation to Sex, publicado dez anos antes:

A principal conclusão a que cheguei nesta obra, a saber, que o homem descende de uma forma baixamente organizada, parecerá, receio dizer, altamente de mau gosto para muitas pessoas. Mas dificilmente pode haver alguma dúvida de que descendemos de bárbaros. Nunca esquecerei o espanto que senti quando vi pela primeira vez um grupo de fueguinos em uma costa selvagem e quebrada por causa da reflexão que me veio à mente: assim eram nossos ancestrais. Estes homens estavam absolutamente nus e borrados de tinta, seus cabelos compridos e emaranhados, suas bocas espumando de excitação e sua expressão era selvagem, assustada e desconfiada. Quase não possuíam nenhuma arte e, como animais selvagens, viviam do que conseguiam pegar; não tinham governo e eram impiedosos com todos que não fossem de sua pequena tribo. Aquele que viu um 
selvagem em sua terra nativa não sentirá muita vergonha se forçado a admitir que o sangue de uma criatura muito mais humilde flui em suas veias. De minha parte, eu preferiria ser descendente daquele pequeno macaco heroico que enfrentou seu temido inimigo para salvar a vida de seu cuidador; ou daquele velho babuíno que, descendo das montanhas, carregava em triunfo seu pequeno camarada para longe de uma multidão de cachorros espantados - do que de um selvagem que se delicia em torturar seus inimigos, oferece sacrifícios sangrentos, pratica infanticídio sem remorso, trata suas mulheres como escravas, não conhece nenhuma decência e é assombrado pelas superstições mais grosseiras.

É desculpável que o homem sinta algum orgulho de ter se erguido, ainda que não através de seus próprios esforços, até o cume da escala orgânica; e o fato de ter assim se erguido, em vez ter sido nela primitivamente colocado, pode dar-lhe esperanças de um destino ainda mais alto no futuro distante. Mas não estamos aqui preocupados com esperanças ou medos, apenas com a verdade na medida em que a nossa razão nos permite descobri-la. Reuni quantas evidências pude; e devemos admitir, como me parece, que o homem, com todas as suas nobres qualidades, com a simpatia que sente pelos mais degradados, com a benevolência que estende não apenas a outros homens, mas à mais humilde criatura viva, com seu intelecto divino que tem penetrado nos movimentos e constituição do sistema solar - o Homem ainda carrega em sua estrutura corpórea o selo indelével de sua baixa origem (Darwin, 1871, vol. 2 p. 404-405).

Esta mesma passagem é usada pela filósofa e psicóloga Vinciane Despret em Quand le loup habitera avec l'agneau ao discutir justamente o modo pelo qual Darwin pôde adequar os animais e selvagens vitorianos à narrativa histórica da evolução. O que Despret explica é que havia, à época de Darwin, numerosos relatos de viajantes e naturalistas, entre outros, a respeito de animais encontrados na natureza e nos jardins zoológicos, nos quais atitudes consideradas honradas e morais tinham sido observadas; nos parágrafos acima citados, dois primatas vêm dar testemunho de sua elevação "espiritual”, aquele que defendeu seu cuidador de um inimigo perigoso e o que salvou um filhote de uma matilha. Por todo o percurso de The Descent of Man... é possível encontrar exemplos desse tipo de animal virtuoso, em quem se chega a reconhecer por vezes o germe de um sentimento tão civilizado como o da vergonha (cf. Despret, 2002, p. 49). Através desses relatos, a continuidade entre primatas morais e homens civilizados poderia ser facilmente estabelecida, o que o naturalista afirma aliás desejar ("De minha parte, eu preferiria ser descendente..."), mas há uma pedra no meio do caminho, a saber, os povos humanos primitivos, que deveriam se encontrar entre o polo da natureza (animais) e o da cultura (homens civilizados), e sobre quem a percepção vitoriana era de imoralidade, para dizer o mínimo. Os primitivos, na infância da história humana, seu exemplar mais próximo da natureza, não possuíam ni foi ni roi ni loi e, mais, eram considerados degenerados, infanticidas, escravistas, 
sexistas, sanguinários e supersticiosos, apenas para lembrar o modo como os fueguinos são descritos. O desafio de Darwin, então, era o de encontrar o fio que passaria do primata por este primitivo miserável até a glória do civilizado, em uma história sem rupturas:

O primitivo deve ele também apresentar características que permitam afirmar e confirmar o laço entre o animal e o homem civilizado: ele deve ser o bom intermediário testemunhando sua humanidade, por um lado; ele deve, por outro, se situar próximo do animal e se parecer com ele, sob pena de romper a continuidade (Despret, 2002, p. 49).

A solução veio por um movimento que degradaria tanto selvagens quanto animais. Tudo teria começado com um semianimal humano que agiria mais por seus instintos que pela razão, mais ainda que os primitivos. Estes ancestrais, entretanto, não praticariam os atos detestáveis dos primitivos, "pois os instintos dos animais inferiores não são jamais tão perversos a ponto de lhes estimular a destruir regularmente seus pequenos ou para lhes retirar todo o sentimento do ciúme" (Darwin apud Despret, 2002, p. 51). O ciúme, explica Despret, é uma virtude que faria com que os machos protegessem suas fêmeas e prole. Deste modo, o caminho até a moralidade humana não teria passado por coragem ou bravura, mas viria pelo contínuo do ciúme - modo encontrado por Darwin para explicar a "regulação da competição em torno das fêmeas" (idem). A seleção natural, ele postulava, dava-se pela via sexual através da escolha de parceiros para o acasalamento; mas, diferentemente de outras espécies, sobretudo pássaros, cujos machos, na competição pelas fêmeas, fariam grandes demonstrações de sua beleza, dança ou canto, entre os primatas outros que humanos os machos não pareciam se importar com isso - além do mais, como nota Despret, Darwin os considerava muito feios. Em seu caso, era o combate pelo poder motivado pelo ciúme que proveria uma explicação a contento para o comportamento de todos os grandes mamíferos. Lutando uns contra os outros através dos séculos, os machos primatas - semianimais e selvagens - garantiriam a posse das fêmeas e a continuação de sua prole. Assim, pela prática de guerra por ciúme no início de sua história (entre os civilizados "cessada há muito tempo" - Darwin, 1781, p. 326), Darwin era capaz de introduzir os primitivos em sua narrativa evolutiva.

A escolha do combate por ciúme como motor da evolução, por outro lado, expulsou os macacos virtuosos da História para a marginalidade das anedotas; se era fato que tal ou tal indivíduo havia se portado de modo moral, isso deixou de 
ser matéria de ciência. A verdade sobre as espécies de primatas, natural, imutável, observável repetidamente, em suma, científica, era uma "de conflito, competição, guerra e ciúme" (Despret, 2002, p. 53). Despret se pergunta o que teria acontecido com a teoria de Darwin caso

[...] o selvagem, por exemplo, não fosse o selvagem vitoriano, produto de uma cultura imperialista e puritana, horrorizada pela diferença, paternalista e racista em um mundo que construía sua origem e sua história no registro da competição. Podemos nos perguntar, em suma, se as coisas não teriam sido outras se Darwin não fosse o herdeiro e o vetor dessa "cumplicidade singular" da política colonial com a antropologia e a história natural ${ }^{53}$ (Despret, 2002, p. 54).

\section{6.}

\section{"Donzellas... para pentear macaco"}

Haraway abre o segundo capítulo de Primate Visions, chamado "Colônias primatas e a extração de valor", situando seu discurso nos estudos de primatologia pré-Segunda Guerra Mundial; "França, Bélgica, Rússia, Alemanha e Estados Unidos" mantinham, já àquela época, "estações de pesquisa e conservação" (Haraway, 1989, p. 19) e não apenas se dedicavam ao estudo dos primatas em um contexto evolutivo, dentro do qual, conforme exposto acima, esses animais ocupavam um lugar especial, mas também os utilizavam já como cobaias de pesquisas medicinais - o que ajudou a permitir e fixar o estabelecimento dos colonos dentro de espaços tropicais: "Literal e figurativamente, os estudos de primatas eram uma questão colonial, na qual o conhecimento dos corpos de macacos e grandes primatas vivos e mortos era parte do sistema de troca desigual do colonialismo extrativista" (idem).

Conforme discutia-se acima, este lugar ocupado pelos primatas era povoado por uma mistura de produção científica e fantasia popular incentivada pela política colonial. Neste contexto, observa Haraway, as instalações que mantinham os animais eram objeto de profunda curiosidade e a "ideologia colonial francesa da missão civilizadora alimentava a imaginação animada e racista dos press releases

${ }^{53}$ Despret procura responder a esta pergunta através do exame da obra de Kropotkin (cf. Despret, 2002), anarquista russo autor de Ajuda mútua: um fator da evolução, de 1902. Tanto Darwin quanto Kropotkin convocam primatas e selvagens para dar conta da teoria da evolução, mas o segundo, que acreditava na cooperação e na socialidade como forças evolutivas muito mais fortes que a competição, denuncia o que Despret chama de "dupla falta de cortesia, que consiste em desqualificar o animal para melhor injuriar os selvagens" (Despret, 2002, p. 60). Realmente, tanto os selvagens quanto os animais vêm, na obra de Kropotkin, dar testemunho da eficácia da cooperação como operador evolutivo mais difundido que a competição. Para a luminar interpretação acerca das diferenças entre Kropotkin e Darwin, cf. Despret, 2002. 
acerca do que se passava por detrás dos muros dos laboratórios" (idem). Se, como observavam Baratay e Hardouin-Fugier, a domesticação era um dos modos de apropriação dos animais pelo império desde o advento do zoológico, a revolução darwinista veio radicalizar a prática por fazer supor ser possível a realização de um grande sonho de domínio da natureza: operar a passagem entre natureza e cultura, isto é, civilizar grandes primatas. Um dos exemplos da "singular cumplicidade" entre ciência e colonialismo vigentes encontra-se em notícias de jornais de 1924 sobre "Pastoria" (de Pasteur), "um posto colonial do Instituto Pasteur em Kindia, na Guiné Francesa" (idem), que, segundo matéria do Chicago Tribune Ocean Times reproduzida por Haraway, anunciava que os franceses "estabeleceriam uma aldeia modelo e escolas para grandes primatas nas quais se testarão experimentos civilizatórios" (idem, manchete do jornal). Outra notícia, do International Feature Service, Inc., também presente em Primate Visions, é ainda mais exagerada: "uma universidade de macacos para tornar os chimpanzés humanos" (idem).

Os artigos explicam como algumas espécies serviriam de cobaias para pesquisa medicinal enquanto outras, as de grandes primatas, por serem mais inteligentes e mais próximas dos humanos, participariam dos tais experimentos de civilização. Ainda é dito que o cuidado com os animais seria "fornecido por mulheres nativas atuando como enfermeiras e por professoras europeias treinadas em psicologia infantil" (idem, p. 20). O alojamento dos primatas é descrito como uma espécie de aldeia na qual cada indivíduo habitaria seu próprio quarto, aquecido por um sistema de água quente; na verdade, como esclarece Haraway, fotografias de Pastoria "revelavam uma pedregosa prisão gradeada, uma arquitetura que era típica do período da cultura primata tanto em metrópoles quanto nas colônias" (idem, p. 20-21). A filósofa exime do frisson sensacionalista o diretor Albert Calmette, cujas declarações seriam "bem mais formais e ponderadas" (idem, p. 20), o que é verdade no que diz respeito à possibilidade de transformar os grandes primatas em homens; a descrição embelezada dos recintos e o tratamento quase suntuoso dos animais presentes nos artigos, entretanto, configuram praticamente a citação de um artigo publicado por ele na revista $L a$ Nature:

os chimpanzés terão cada um sua pequena casinha, construída sobre pilotis, a alguma distância do sol, para a noite. Eles ficarão presos pela cintura a uma 
corrente suficientemente longa. Durante o dia, gozarão da maior liberdade vigiada. Farão passeios levados pela mão, como crianças. Mulheres indígenas lhes servirão de nurses [...] (Calmette, 1924, p. 260).

Os planos de Calmette para um laboratório a ser instalado em Paris são ainda mais generosos em relação aos primatas. Os aposentos deveriam contar com aquecimento e fonte d'água para banho, sendo construídos de modo a "imitar a arquitetura de 'palácio' ou 'rotundas' de nossos jardins zoológicos” (idem). O cuidado com os filhotes é referido com minúcias que certamente encheram os olhos daqueles que acreditavam na possibilidade de civilizar os animais: eles seriam "nutridos através de mamadeiras ou por colher com leite esterilizado" e uma "infusão de cereais sempre frescos" (idem), até que se habituassem a comer "arroz branco adoçado, biscoitos, um pouco de carne de frango cozido e a beber chá açucarado" (idem, p. 261).

Uma pesquisa não exaustiva em periódicos brasileiros de grande circulação da época revelou uma recepção tardia e de caráter jocoso do laboratório de Calmette; na Revista da Semana, em 1925, lia-se que "não é muito fácil criar um chimpanzé"; tanto nela como no semanário humorístico Careta, simplesmente foram trazidos excertos e feitas paráfrases do artigo de Calmette sobre o tratamento dos "animaesinhos" (Careta, 02/10/1926, p. 36). Já O Estado do Paraná aproveitou para, na capa de sua edição de 8 de outubro de 1925, ironizar tanto a ideia da humanização símia como a participação de mulheres no empreendimento. Intitulado "Donzellas para... pentear macacos", o artigo descreve o alojamento como possuindo "todo o mais moderno conforto e todas as mais apetecíveis commodidades", e a operação destinando uma "donzella" para cuidar de cada "mono": "serão tratados como creaturas e se procurará ensinar-lhes a falar, ler, escrever... tal e qual como se eles fossem iguaes aos homens!" Há um embaralhamento de funções e objetivos, os primatas devendo ser tornados homens com o fim de servirem como boas cobaias para pesquisas de enfermidades humanas. O lugar das mulheres - ocidentais e indígenas - também é objeto de piada; primeiramente, a ida de americanas a Pastoria é vista como uma melhoria para a vida dos animais, que receberiam assim "uma assistencia mais scientifica". E, finalmente, na conclusão do pequeno artigo, o autor anônimo se mostra preocupado com que a "innata curiosidade feminina" tire aos animais, uma vez 
humanizados, também seu Paraíso, "levando-os a um valle de lagrimas" (O Estado do Paraná, 08/10/1925).

A maioria dos artigos encontrados em periódicos brasileiros da Primeira República, entretanto, ao mencionar Calmette, trata com seriedade as suas pesquisas médicas, principalmente aquela destinada ao desenvolvimento de uma vacina contra a tuberculose, a "peste branca", uma das principais causas de morte no Rio de Janeiro desde o final do século XIX (cf. Correio da manhã. 2/08/1924; O Paiz, 02 e 03/11/1925; O Paiz, 06/01/1926; Nascimento, 2005). Em apenas um dos jornais consultados, $O$ Dia, aparece uma crítica ao uso de animais em experimentações, um questionamento sobre o "sacrifício do irracional" na base das "melhorias" conquistadas para a humanidade. A esta última, totalmente dependente, para sua sobrevivência, dos animais, que de sua parte não precisariam dos homens, é lançada a pergunta: "não será a civilização um paradoxo?" (O Dia, 24/09/1924).

O trânsito entre humanidade e animalidade idealizado e marcado nos grandes primatas também levou a uma série de práticas de transplantes transespecíficos. Um dos mais célebres e estranhos defensores dos enxertos, como eram chamados à época, Serge Voronoff, prometia, em sua ida ao Rio de Janeiro em 1928, a criação de "uma nova e poderosa raça humana" (Gazeta de Notícias, 03/04/1928) através de um método de rejuvenescimento logrado pelo transplante de tecidos de primatas, sobretudo de testículos, mas também de glândulas como a tireoide, em seres humanos. O cirurgião francês de origem russa, que propunha o estabelecimento de "criações de macacos" "na costa de Nápoles até Marselha", afirmava ser capaz de produzir "artificial[mente] uma raça humana superior" (idem). Não se deve subestimar a repercussão dessas iniciativas: em $O$ Hotel da fuzarca (The Cocoanuts), filme dos irmãos Marx de 1929 adaptado de uma peça escrita por George S. Kaufman e estrelada pelos comediantes em 1925, há uma música composta por Irving Berlin, Monkey Doodle-Doo, na fita cantada por Mary Eaton, que, além de abrir com versos que caracterizam os macacos livres como mais felizes que os de zoológico e fazer referência a Darwin, menciona os experimentos de Voronoff: "If you're too old for dancing/ Get yourself a monkey gland/ And then let's/ Go my little dearie, there's the Darwin theory/ Telling me and you/ To do the Monkey Doodle Doo." 
A respeito das notícias acerca do trabalho de mulheres indígenas nas estações de pesquisas de primatas, Haraway comenta que

A confusão sobre se as "mulheres nativas" seriam meramente servas dos jovens animais ou também suas guias e professoras sugere a confusão de limites nas regiões inferiores da grande cadeia do ser. Nela, os corpos marcados por raça, sexo e espécie deleitavam os empreendimentos coloniais tropicais que uniam negro, mulher e animal em fantasia e em trabalho social forçado (Haraway, 1989, p. 20).

É possível, a partir daí, em um movimento de expansão de e retorno aos "empreendimentos coloniais", considerar "a caça, o zoológico, a aclimatação e a domesticação", as exibições públicas de povos exóticos, a incerteza etnológica e popular acerca desses povos e de pessoas com deficiências, o formato assemelhado ao panóptico dos recintos e ilhas redondas em zoológicos e laboratórios, as passagens imaginadas entre animais, selvagens e vitorianos, o uso de primatas como bons substitutos para corpos humanos em pesquisa científica e os delírios eugenistas contidos nas práticas de misturas transespecíficas; em suma, considerar que a ligação, confusão e as subsequentes marcas entre e em povos não-ocidentais, deficientes, animais e mesmo mulheres em ações e discursos coloniais, populares e científicos criam uma enorme zona de indistinção no sentido agambeniano que esses corpos vêm habitar. De um lado, o homem próprio; de outro, uma infinidade de entes indiferentes entre si que confirmam o estatuto dessa humanidade.

Agamben afirmava o "singular privilégio" da vida nua na política ocidental de "ser aquilo sobre cuja exclusão se funda a cidade dos homens" (Agamben, 2002, p. 15); mas uma breve pesquisa sobre o zoológico como instituição contemporânea à modernidade colonialista permite uma reformulação desta ideia: é desde o zoológico como empresa colonial, passando por tudo que é capturado, indiferenciado e atravessado pelo movimento de soberania imperial propriamente humana que "se funda a [moderna] cidade dos homens" (idem). Não haveria, assim, como pensar esta política sem passar pela indistinção entre uma série de viventes - animais, negros, deficientes, selvagens e mulheres. Trata-se do jardim zoológico como modelo do campo de concentração. Mas, como veremos a seguir, esta não é a única política possível. 


\section{7. \\ E, ainda assim, brincaram}

Haraway, comentando Derrida, pergunta-se por que o filósofo em $O$ animal que logo sou privou-se de estabelecer um diálogo, em suas especulações a respeito dos animais, com aqueles que trabalham diretamente com eles, a saber etólogos e cientistas de comportamento animal - aos quais seria possível ainda acrescentar criadores, guardas de parques, nativos de regiões coabitadas por humanos e animais e uma dezena de outros - quando, de modo justo, acusa toda uma tradição da história da filosofia ("Descartes, Kant, Heidegger, Lacan, Levinas" -Derrida, 2002, p. 33) de não ter levado em conta "a experiência do animal que vê, do animal que os observa [...] na arquitetura teórica e filosófica de seus discursos" (idem). Não que todas as pessoas que trabalham ou vivem diretamente com os animais levem em consideração o olhar deles, é claro, mas algumas dentre elas, dada a miríade de discursos produzidos a respeito dos animais, seriam capazes de informá-lo ou de se constituir como boas interlocutoras. A pergunta de Haraway pode ser resumida em uma frase: "por que Derrida não examinou as práticas de comunicação fora das tecnologias sobre as quais ele sabia falar?” (Haraway, 2008, p. 21).

Para ela, não ter percorrido essa via deixou o filósofo sem outra escolha exceto, diante do olhar de sua gata, voltar-se à questão que ele considera "prévia e decisiva", cuja "forma muda tudo" (Derrida, 2002, p. 54): "Eles podem sofrer?,

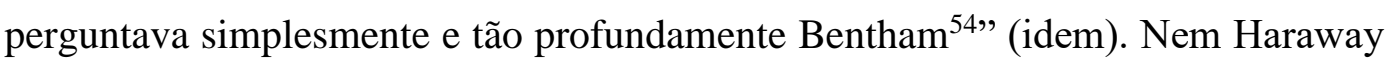
(cf. Haraway, 2008, p. 22) nem a presente tese, é claro, pretendem desmerecer a questão do sofrimento animal - como, espera-se, fica claro pela sequência argumentativa que deságua neste momento. A "guerra à piedade" mencionada no primeiro capítulo desenha um espaço de pensamento e atuação não apenas da maior importância, mas riquíssimo de questões e problemas: "pensar começa talvez aí" (Derrida, 2002, p. 57). E, de fato, depois da pequena discussão travada aqui acerca da história dos zoológicos, é o sofrimento dos animais que primeiro salta aos olhos; reconhecer esse sofrimento, reconhecer a guerra que se impõe contra eles e começar daí é um passo mais do que justificado. Mas este não é o

\footnotetext{
${ }^{54}$ Quis o destino, ironicamente, que o inventor do Panóptico - talvez influenciado pela ménagerie real -, também tivesse proferido este lema de muitos teóricos e ativistas dos direitos animais.
} 
único caminho, como propõe Haraway. Os macacos-aranha observados por Bateson em São Francisco, por exemplo e apesar de tudo, brincavam, e isso abriria toda uma outra série de questões:

[...] quão mais promissoras são as perguntas: podem os animais brincar? Ou trabalhar? E ainda: será que eu posso aprender a brincar com esta gata? Posso eu, o filósofo, responder a um convite ou reconhecer um quando ele é oferecido? E se trabalho e brincadeira, e não apenas piedade, se abrissem quando a possibilidade da resposta mútua, sem nomes, fosse levada a sério como uma prática disponível para a filosofia e a ciência? E se uma palavra utilizável fosse alegria? E se a questão de como os animais engajam responsivamente o olhar uns dos outros [engage one another's gaze responsively] tomasse o centro do palco para as pessoas? E se fosse esta a pergunta, uma vez seu protocolo tendo sido propriamente estabelecido, cuja forma muda tudo? (Haraway, 2008, p. 22).

Em primeiro lugar, parece, é a possibilidade da resposta, e não da mera reação do animal, que se deve considerar. O sofrimento, por mais terrível e sério que seja, retira dos animais - não só dos animais - a sua possibilidade de agir: perguntar “'eles podem sofrer?' consiste em perguntar-se 'eles podem não poder?

[...] Poder sofrer não é mais um poder, é uma possibilidade sem poder, uma possibilidade do impossível"” (Derrida, 2002, p. 55). O que mudaria caso o eixo se deslocasse, caso se considerasse aquilo que os animais podem? O modo como respondem, agem, criam? Em suma, que outra política se abriria para além da piedade, do poder soberano, da inoperosidade?

\subsection{1.}

\section{"Fair play"}

Vejamos as promessas da brincadeira, aquela mesma atividade na qual Bateson havia encontrado um momento fundamental da evolução da comunicação. Bekoff vem se debruçando sobre esse comportamento principalmente entre mamíferos desde os anos 1970, tendo uma série de artigos e livros publicados. Percebe-se sua hesitação, em "Social play behavior”, de 1984, acerca da definição e das possibilidades interpretativas da brincadeira; neste artigo, ele propõe que

Brincadeira é toda a atividade motora performada depois do nascimento que parece ser sem propósito, na qual padrões motores de outros contextos podem frequentemente ser usados em formas modificadas e sequenciamento temporal alterado (Bekoff, 1984, p. 229). 
Que a brincadeira seja "sem propósito", Bekoff observa, não quer dizer que ela não tenha funções; essas funções, entretanto, são variadas, dependendo não apenas da espécie, mas dos grupos em questão, e podem envolver o desenvolvimento de "força física, resistência, habilidade", "regula[r] taxas desenvolvimentais", "reproduzir[r] informações específicas", "desenvolve[r] habilidades cognitivas necessárias para a adaptabilidade comportamental, flexibilidade, inventividade ou versatilidade", constituir "um conjunto de táticas comportamentais usadas na competição intraespecífica", "estabelece[r] ou reforça[r] laços sociais em uma díade ou coesão social em grupo" e funcionar como um "treinamento cognitivo" (idem, p. 231). Bekoff vem se concentrando, desde então e cada vez com mais convicção (advinda de pesquisas de etologia cognitiva, neurociência e etologia narrativa, entre outras), na relação entre brincadeira e justiça - ou moralidade, como costuma dizer. Se em 1984 a hipótese era sugerida com muito cuidado, em 1998, o subtítulo de outro artigo seu, "Social play behavior - cooperation, fairness, trust and the evolution of morality", demonstra a direção tomada por seu trabalho. A brincadeira, ele afirma, deve ser negociada e aceita, e os participantes não podem trapacear, sob pena de não encontrarem mais parceiros - ou seja, é preciso agir de modo justo [fair]. Há marcadores específicos que exprimem que uma mordida vindoura não significa uma mordida de verdade, por exemplo, e estudos em canídeos demonstram que esses sinais quase não são usados de modo enganador; em brincadeiras transespecíficas são observados pequenos movimentos, como trocas de olhares rítmicas, para reafirmar o caráter de jogo. $\mathrm{Na}$ brincadeira, posições sociais são deixadas de lado, e alguém com uma posição hierárquica mais alta pode se engajar em um jogo com um companheiro de posição inferior, permitindo que este, durante aquele momento, se encontre em lugar de igualdade ou mesmo que se opere uma inversão de lugares; indivíduos mais fortes ou adultos podem se engajar em self-handicapping, fingindo-se menos poderosos, diante de outros mais fracos ou filhotes. "Há uma certa inocência ou engenhosidade na brincadeira", afirma Bekoff (Bekoff, 1998, p. 84), reforçando seu caráter duplo - fazer isto querendo significar aquilo. Para ele, a brincadeira oferece aos seus participantes a oportunidade de descobrir, em um ambiente seguro, como agir uns diante dos outros, inclusive na resolução de conflitos.

Em 2009, em parceria com a filósofa Jessica Pierce, esta ideia encontrou sua forma mais bem acabada no livro Wild Justice: the Moral Lives of Animals. Nele, 
os autores afirmam peremptoriamente que os "animais sentem empatia uns pelos outros, tratam-se de modo justo, cooperam em direção a objetivos comuns e se ajudam uns aos outros em caso de problemas. [...] em suma, que os animais têm moralidade" 55 (Bekoff e Pierce, 2009, p. 1). Mais que isso, consideram que essas vidas morais não devem ser comparadas à humana, mas compreendidas em sua singularidade não apenas específica, mas grupal: "não há uma 'natureza lupina', mas "naturezas lupinas"” (idem, p. xii). No livro, a brincadeira não é o único comportamento analisado, embora seja considerada como o que "oferece a evidência mais convincente acerca de um sentido de justiça [fairness] em mamíferos sociais" 56 (idem, p. 115) e figura no que eles chamam de "aglomerado da justiça", que também inclui "compartilhamento, equidade [...] e perdão" (idem, p. xiv). Brincar, que requer habilidades como boa negociação e justiça ("unfair play é um oximoro", idem, p. 116), também promove um tipo de inteligência criativa, os animais improvisando sequências de movimentos e alterações neles o tempo todo - além de ser tremendamente divertido. Despret comenta, a esse propósito, que na brincadeira os animais aprendem a responder no sentido harawayiano e a respeitar - respicere, olhar de novo - de um modo concreto, corporificado. Ela é também um lugar de transformações:

Se há algo que a brincadeira faz é justamente mudar as significações, romper com o literal. A brincadeira é o paraíso da homonímia: um gesto que, em outros contextos, traduz medo, agressão, relação de forças, se rearranja, se desfaz e se refaz de outro modo. A brincadeira é o lugar da invenção e da criatividade, o lugar da metamorfose do mesmo em outro, tanto para os seres quanto para as significações. Ela é o lugar mesmo do imprevisível, mas sempre segundo regras que conduzem esta criatividade e seus ajustamentos. Em suma, é justiça na graça da alegria (Despret, 2014, 111).

Wild Justice parece um livro direcionado, entre outras, à discussão com partidários de certas correntes da chamada ética animal que propõem uma

55 A moralidade é definida pelos autores "como um conjunto de comportamentos interrelacionados que dizem respeito aos outros e regulam interações complexas dentro de grupos sociais. Esses comportamentos se relacionam a bem-estar e prejuízo, e normas de certo e errado se anexam a muitos deles. A moralidade é essencialmente um fenômeno social, emergindo das interações entre animais individuais, e existe como um emaranhado de fios que mantém unida uma tapeçaria complicada e variável de relações sociais. A moralidade neste sentido age como uma cola social" (Bekoff e Pierce, 2009, p. 7).

56 Apesar de tratarem da moralidade performada na brincadeira apenas em mamíferos sociais - inclusive porque nessa caso a evidência científica lhes permite realizar a articulação de modo mais embasado -, a brincadeira é um comportamento encontrado em muitos outros grupos filogenéticos, como "aves e mesmo crustáceos" (Bekoff e Pierce, 2009, p. 117). Quanto aos sentidos morais nesses outros animais, vale a pena seguir o credo científico que afirma que ausência de evidência não é evidência de ausência. 
consideração moral dos animais como pacientes mas não como agentes morais (cf. por exemplo Regan, 1983; Singer, 2002; e Francione, 2008). Nada indica que Bekoff e Pierce sejam avessos à proposição de que os animais devam possuir direitos - pelo contrário - mas, ao afirmar a sua vida moral, a questão poderia extrapolar a esfera do direito na qual essa discussão costuma se encerrar. Isto é, seria possível interpretar a asserção de uma moralidade animal como escapando das regiões dominadas pelo direito e entrando na esfera política de ação e pensamento; se há tantas formas de moralidade como há mundos, como isso modificaria o modo de também os humanos habitá-los? Essa questão seria capaz de transformar o problema moral em problema político, na medida em que passaria a dizer respeito à coabitação por diferentes entes de diferentes mundos que no entanto se encontram e superpõem. Não é este, porém, o caminho que os autores seguem. Eles dedicam parte da conclusão de seu livro ao conceito de agência, afirmando que a dualidade agente/paciente não é promissora e deve ser abandonada - nem animais agiriam inteiramente levados pelo instinto nem os humanos estariam desligados de sua animalidade, além do que poderia haver moralidade mesmo em comportamentos instintivos. Pois "onde há flexibilidade e plasticidade de comportamento, há agência” (Bekoff e Pierce, 2009, p. 145) - um movimento capaz de unir humanos e muitos animais mas que excluiria os insetos, por exemplo, que não possuiriam essa plasticidade. De todo modo, para os autores, a moralidade animal estaria restrita à sua comunidade: um lobo, por exemplo, agiria moralmente dentro de seu grupo mas não diante dos alces que ele mata e come. Neste sentido, Bekoff e Pierce, que por um instante propunham desafios políticos, acabam retornando ao campo demasiado humano do direito e da ética. Para os autores, parece, é falta de educação - e de moralidade - brincar com a comida.

É curioso perceber que a discussão em torno da moralidade supõe a humanidade como uma espécie de modelo; ainda que muitos autores critiquem a civilização ocidental por não considerar os animais como parte de sua comunidade moral, eles presumem que os humanos agem moralmente diante de seus pares e, portanto, podem fazer o mesmo com os animais. O que a história da colonização e das guerras, o racismo, o sexismo e o classismo mostram, entretanto, é que nem sempre isso se verifica. Embora sua obra seja brilhante e tenha feito avançar questões em torno das relações com os animais, o autor se aprisiona em modelos 
estruturais profundamente humanos; afinal, por que "desmoralizar" um lobo que mata para se alimentar? Poderíamos perguntar a Bekoff se comer não faz parte da vida, tanto dos lobos como dos humanos. O que seria preciso para que os lobos comessem moralmente? Que dessensibilizassem os alces antes de atacá-los, como prescrevem as orientações humanas de bem-estar animal direcionadas a abates de animais de produção? Contudo, não são os lobos que mantêm suas presas em regime de confinamento forçado, em instalações aos bilhões, nas piores condições de vida, submetendo-os a seleção artificial que deforma seus corpos.

Se há um ou dois problemas com a questão dos direitos animais, eles não passam pelas melhorias alcançadas - como dizia Derrida, há uma guerra contra eles - mas por se concentrarem em um quadro que, de saída, exclui os animais de sua agência enquanto concede as possibilidades mais sublimes para a humanidade. De Waal se opõe à ideia dos direitos animais e considera ultrajante "o paralelo com a abolição da escravidão - que, além de ser insultante - é moralmente falho: escravos podem e devem se tornar membros plenos da sociedade; animais não podem e não vão" (de Waal, 2006, p. 77). O autor holandês não explicita que sociedade é essa, mas provavelmente se refere àquela de que faz parte, a mesma que, por exemplo, garantia liberdade a seus cidadãos ao mesmo tempo que desempenhou um papel de destaque no tráfico de escravos pelo Atlântico entre os séculos XVII e XIX, mantendo colônias na África, na América e na Ásia até o século XX. Não há como negar que as marcas de animalização são codificadas em corpos negros em uma zona de indistinção onde se criam escravos pela hiperseparação entre humanidade própria e animalidade. A condição de possibilidade da escravidão (e do racismo) é a animalização de determinados humanos, desde a ideia aristotélica de que os escravos, por natureza, não possuíam lógos, até discussões sobre a existência ou inexistência de alma em povos diferentemente humanos, passando pela confusão entre primatas e povos nativos em contextos evolutivos.

De Waal diz ainda que "apesar de muitos animais sociais terem desenvolvido tendências altruísticas e afetivas, eles raramente, se é que o fazem, as direcionam a outras espécies" (idem, p. 77), dando como exemplo "o modo como o guepardo trata a gazela" (idem), e contrapondo a esse comportamento o de sua própria espécie, Homo sapiens, "a primeira a aplicar tendências que evoluíram dentro do grupo a um círculo maior de humanidade" (idem) - em uma 
afirmação que parece colocar entre parênteses não só toda a história de sua sociedade como o mundo mesmo em que atualmente vive, pleno de desigualdades intraespecíficas. Mais uma vez, pode-se replicar que nunca se ouviu falar de um guepardo mantendo gazelas confinadas em gaiolas nas quais elas não têm espaço para se mover, como fazemos com as galinhas, ou as reproduzindo em baias que não lhes permitem sequer se virar, como no caso de porcas. Para de Waal, "direitos são parte de um contrato social que não tem sentido sem responsabilidades" (idem). O autor não se dá sequer ao trabalho de enunciar por que animais não podem assumir essas responsabilidades. Ora, como as sociedades animais poderiam sequer existir sem a assunção de "responsabilidades" tais como forragear, proteger filhotes etc.? Ou, ainda, não será claro que os animais de criação, sobretudo em relações menos assimétricas de poder, como quando vivem com pequenos produtores, trabalham? E como poderiam fazer isso sem um sentido de responsabilidade do modo como o próprio de Waal o determina? (cf. Despret e Porcher, 2007; Despret, 2014). É essa tendência de elevação da humanidade a um ideal que não se verifica historicamente, em prejuízo da admissão do comportamento animal real que costuma acompanhar as discussões em torno de direitos e moralidade. Ademais, poderíamos perguntar por que o discurso sobre a moralidade animal tão constantemente recai sobre o tema da caça com objetivo alimentar. Em mais um procedimento de criação de zonas de indistinção, as populações indígenas, por exemplo, são frequentemente atacadas, desta feita por defensores de direitos animais, por caçarem para se alimentar assim como o lobo ou o guepardo. A propalada humanidade moral, que causa tanto sofrimento mas tem em seu íntimo as mais brilhantes e inocentes possibilidades, pode comer sem matar; pode matar sem causar dor; e pode acusar todo o resto dos viventes de imoralidade.

Por outro lado, de Waal levanta um problema importante no discurso dos direitos, a questão do contrato e da lei, dispositivos demasiadamente humanos - e pertencentes ao âmbito de uma só humanidade, aquela que se constitui sob o signo dos Estados nacionais regidos pelo direito. Direitos animais universais pressuporiam que todos os animais fossem contemplados como iguais, como se não houvesse uma diferença brutal não apenas entre espécies, mas entre práticas e contextos, o que deixa em aberto problemas como o dos direitos de insetos individuais, ou mesmo de como diferenciar os merecedores dos que não merecem. 
O próprio de Waal considera que devemos mudar nossas atitudes em relação aos símios e já exprimiu contrariedade diante dos atuais modos de produção de carne $^{57}$, preocupações diferentes para diferentes espécies - ou melhor, preocupações diferentes para diferentes práticas.

O jurista Daniel Braga Lourenço analisou em artigo as propostas atualmente em tramitação no Congresso Nacional Brasileiro que têm por objetivo alterar o estatuto jurídico dos animais (Lourenço, 2016), notando que, diferentemente dos projetos de outros países, no Brasil a tendência não é procurar uma terceira categoria para os animais, entre coisa e pessoa, mas que

Dos quatro projetos que temos a respeito deste tema, três preferem realizar o enquadramento dos animais como sujeitos de direitos, seja personalizando-os, seja tratando-os como entes despersonalizados, ou mantendo-se omissos quanto a este ponto (Lourenço, 2016, p. 831)

O autor conclui que a confusão na especificação do lugar e dos direitos dos animais nesses textos enfraquece as propostas. Ele nota ainda que

\begin{abstract}
O direito penal, por sua vez, trabalha com a concepção de que deixar atos cruéis impunes poderia colaborar para o embrutecimento do homem em relação ao seu próprio semelhante. Esta tese recebe o nome de "transbordamento moral", pois seu fundamento está em afirmar que aquele que reiteradamente pratica o mal para com os animais poderá, ao menos potencialmente, tornar-se insensível ao sofrimento humano. Portanto, quando a legislação penal, regulamentando a norma constitucional que veda a crueldade, estabelece tipos penais associados aos maus tratos, como é o caso paradigmático do art. 32 da Lei n. 9.605/98, estaria em realidade tutelando a própria humanidade e não os animais, que não seriam vistos como vítimas ou sujeitos passivos das condutas abusivas e sim meros objetos materiais do tipo penal, tal como ocorre, por exemplo, com uma cadeira ou um telefone celular, no crime de dano previsto no art. 163 do Código Penal. É como se houvesse uma projeção de atentado à dignidade humana na violação perpetrada diretamente contra o animal. Podemos exemplificar esta colocação com o caso de danos corporais impingidos aos animais. O entendimento predominante é de que a mutilação meramente recreativa de um animal deve ser punida em função deste ser vivo refletir a vida e a integridade físico-psíquico humanas e, por tal razão, tal atentado ao animal atingiria reflexamente a própria dignidade humana e não a integridade e a dignidade existencial do próprio animal (idem, p. 819-820).
\end{abstract}

Esse entendimento é herdeiro daquele de Kant explicitado na Metafísica dos Costumes. Kant, ao elaborar sua obra, tinha em vista uma dupla luta. De um lado os empiristas, do outro os racionalistas - e o que estava em jogo em cada uma

57 "Eu mesmo gosto de carne e como, mas as práticas da agroindústria de carne me incomodam por razões éticas, e eu ficaria muito feliz se pudéssemos mudar essas práticas ou criar carne na ausência de um sistema nervoso. Refiro-me a fábricas de cultivo de carne, nas quais os músculos crescem sem que o animal inteiro cresça, de modo que o sofrimento possa ser excluído. Esta possibilidade parece estar se aproximando e removeria o dilema ético para mim." (http://wonderlancer.com/socialogue/frans-de-waal-the-age-of-empathy/) 
dessas vertentes era a relação entre razão e fins (últimos). Para os primeiros, os fins são sempre naturais. Para os segundos, transcendentes. O que Kant estabelecia, originalmente, é que os fins supremos são sempre fins da razão (cf. Deleuze, 1987). A razão é, assim, a única e própria juíza de si mesma. A implicação dessa concepção para a ética, o direito e os animais é que, segundo ela, só os entes finitos e racionais podem ser fins em si mesmos - opondo-se assim às coisas, simples meios. Quando diz "entes finitos e racionais" em vez de "humanidade", o filósofo está abrindo a possibilidade de que haja outros entes finitos e racionais além do homem, mas não nos enganemos: não se trata da abertura para que algum animal desta terra possa ocupar tal lugar, senão da chance de que, por exemplo, extraterrestres existam (cf. Kant, p. 215 e ss.) Ainda que cada coisa na natureza, para Kant, aja segundo leis, somente os entes racionais têm a capacidade de derivar, pela razão, ações a partir dessas leis, possuindo assim uma vontade. E o filósofo é incisivo: os entes racionais nunca podem ser meros meios para o uso de uma vontade, eles são fins em si mesmos. São pessoas. De outro lado há as coisas, de valor relativo. As pessoas têm dignidade [Würde]; as coisas, por serem substituíveis, têm preço [Preis] (cf. Kant, 1984, p. 134 e ss.) Fica claro de que lado se encontram os animais.

É importante ainda lembrar que o que está em jogo na garantia dos direitos legais dos entes racionais não é proteger seus interesses mais básicos, mas definir e assegurar um domínio máximo de liberdade a cada cidadão (cf. Kant, 2013). As pessoas, Kant acreditava, têm um direito inato à liberdade, definida como "a independência em relação ao arbítrio coercitivo de um outro" (Kant, 2013, p. 81,7). Trata-se de um dever, assim, e não de uma conveniência, viver em um Estado que possua um sistema legal capaz de assegurar os direitos de cada um de modo que se possa maximizar a sua liberdade. Em uma palavra, o sujeito de direito kantiano é autônomo. Para os animais, "em quem se pode mandar à vontade" (Kant, 2006, p. 27), resta assim o conceito inverso, a heteronomia.

$\mathrm{Na}$ Metafísica dos costumes, Kant explica que qualquer suposto dever diante de outros entes que não os humanos não passa, afinal, de dever para consigo mesmo. Isto é, que se ou quando houver obrigações em relação a outros entes, estas são, na verdade, obrigações para com os homens e é preciso que ninguém se confunda em relação a isso. A destruição do que é belo na natureza, por exemplo, é contrária ao dever do homem pois enfraqueceria a tendência a amar algo sem ter 
como propósito a utilidade, tendência esta que prepararia para a moralidade. Isto é, que os homens só tenham obrigações morais para com eles mesmos não significa que as coisas não possam estar contidas, como meios que são, nestas obrigações. E é assim em relação aos animais; tratá-los de forma cruel é contrário ao dever do homem para consigo mesmo pois assim ele enfraquece uma disposição natural a ser moral com outros homens. Segue-se daí uma lista de prescrições sobre o tratamento que deve ser dispensado aos animais:

[...] o homem [está] autorizado a matá-los de modo rápido (sem infligir agonia), bem como ao seu trabalho árduo, mas não além de suas forças (ao qual os homens também têm de se submeter). Mas experimentos físicos agonizantes a serviço da mera especulação, quando o objetivo almejado poderia também ser atingido os dispensando, são abomináveis. A própria gratidão pelos serviços prestados durante longo tempo por um velho cavalo ou um velho cão (como se fossem membros da casa) pertence indiretamente ao dever do homem, a saber, em relação a estes animais, mas considerado diretamente é apenas um dever do homem para consigo mesmo (Kant, 2013, 510,6; tradução modificada).

Kant, depois de ter arrancado dos animais a possibilidade de serem outros que não coisas, parece ter uma posição que hoje poderíamos até considerar bemestarista. Mas o que significa, no fundo, que esses deveres sejam todos indiretos e ao cabo e ao fim só os homens importem? O que significa, para os animais, que sejam coisas com direitos, ou mais precisamente, coisas em relação às quais temos deveres? Parece que a resposta é: Kant é um gentil senhor de escravos.

A ideia de direitos animais universais apresenta ainda uma dificuldade que podemos aproximar da crítica que Deleuze e Guattari faziam aos direitos humanos: são abstratos demais, não dizem respeito a situações específicas, a povos e questões situados, "não dizem nada sobre os modos imanentes de existência do homem provido de direitos" (Deleuze e Guattari, 2009, p. 140). Além disso, os direitos humanos "podem coexistir no mercado com muitos outros axiomas, especialmente na segurança da propriedade, que os ignoram ou ainda os suspendem, mais do que os contradizem" (Deleuze e Guattari, p. 139). No caso dos animais, isso aparece de modo muito concreto nas mencionadas propostas de mudança de seu estatuto jurídico: como transformá-los, em nossa atual legislação, de bens em sujeitos de direito, universalmente? Os animais de produção não poderiam mais ser mortos, as cobaias deveriam ser libertadas, o que por si só já mudaria toda a configuração atual de nossa sociedade, mas também os insetos, como mosquitos vetores de doenças, teriam o mesmo direito à vida. A questão dos 
direitos também poria em jogo, assim, a insuficiência da categoria de animal, como se a ideia desses direitos implicasse o colapso da ideia de animalidade em oposição à humanidade; seria então necessária a criação de declarações universais de direitos de cada espécie ou subespécie ou mesmo de cada grupo, considerando as particularidades de seus modos de vida. E aí, o quão universais seriam esses direitos e o quanto aproximar-se-iam da jurisprudência? Em 1988, Deleuze dizia em entrevista que

Nos Estados de direito, não são os direitos adquiridos e codificados que contam, mas tudo aquilo que atualmente constitui um problema para o direito, tudo o que leva as conquistas a correrem risco permanente de serem novamente questionadas. Não nos faltam tais problemas hoje, o código civil tende a rachar por todos os lados, e o código penal conhece uma crise igual à das prisões. O que é criador de direito não são os códigos ou as declarações, é a jurisprudência. A jurisprudência é a filosofia do direito, e procede por singularidade, por prolongamentos de singularidades (Deleuze, 2004, p. 191).

No Abécédaire, Deleuze confessava a Claire Parnet que era um "apaixonado pela jurisprudência. Se não tivesse feito Filosofia, teria feito Direito. Mas não direitos humanos. Teria feito jurisprudência, porque é a vida! Não há direitos humanos, há direitos da vida. Muitas vezes, a vida se vê caso a caso" (Deleuze, 1996). Talvez a relação dos animais com os direitos encontre muito mais compromisso no âmbito da jurisprudência, do caso a caso, em uma ecologia de práticas cosmopolíticas.

De Waal propõe o abandono do discurso dos direitos em favor de um "sentido de obrigação" (de Waal, 2006, p. 77): "deveríamos usar os novos insights sobre a vida mental dos animais para promover nos humanos uma ética do cuidado na qual os nossos interesses não são os únicos em jogo" (idem). Também Bekoff, em entrevista ${ }^{58}$, disse preferir o termo "proteção animal" em vez de "direitos animais", pela controvérsia que cerca o segundo, o qual, de acordo com ele, quando proferido, barra a conversa. Mesmo sendo possível dirigir críticas aos dois autores, seria absurdo acusá-los de não se interessarem pela questão do lugar dos animais em nosso mundo, cada um habitando o problema a seu modo. Ambos, entretanto, parecem se encontrar - como também se encontram pelo menos parte dos discursos sobre direitos que consideram animais como "incapazes" no sentido do Código Civil, em um grupo de discursos que, de modo antropocêntrico, deseja reservar um lugar para a inocência. Em um dos muitos momentos iluminadores de

$58 \quad$ https://www.forbes.com/sites/michaeltobias/2012/05/21/the-hearts-and-minds-ofanimals-a-discussion-with-dr-marc-bekoff/\#3e6a0424cb8d 
O animal que logo sou, Derrida fala sobre a "lógica imperturbável, ao mesmo tempo prometeica e adâmica, ao mesmo tempo grega e abraâmica (judeu-cristãislâmica)" (Derrida, 2002, p. 44), da superioridade "incondicional e sacrificial" (idem) do homem sobre o animal. Ela é sacrificial porque o animal é o "bode expiatório" do homem, aquele que pode ser morto, que é um bom substituto para o corpo humano. "Perguntem pois ao asno ou ao carneiro de Abraão ou aos viventes que Abel soube oferecer a Deus: eles sabem o que lhes ocorre quando os homens dizem 'eis-me aqui' a Deus, depois aceitam sacrificar-se, sacrificar seu sacrifício ou perdoar-se" (idem, p. 59). Somos, ou pensamos ser, capazes de respeitar o mandamento "não matarás" apenas se houver uma infinidade de vítimas cujas mortes não se configurem como mortes próprias. O que a lógica do sacrifício, que pretende eximir a humanidade de seus crimes, cria é uma multiplicidade de seres matáveis. O autor questiona: "Dever-se-ia aceitar dizer que todo assassinato, toda transgressão do 'Não matarás', só pode visar ao homem [...], e que em suma só há crime 'contra a humanidade'?” (idem, p. 88).

A dificuldade que Derrida levanta com este argumento envolve o assassinato - o assassinato de animais por homens. Mas, como se viu nos argumentos sobre moralidade, há os que objetam aos assassinatos dos animais por outros animais. Haraway recupera o fio do filósofo para, por um lado, dessacralizar a morte e, por outro, diferenciá-la do exterminismo. "Por mais que tentemos nos distanciar", ela diz, "não existe um modo de viver que não seja também um modo de alguém outro, não apenas algo, morrer de modo diferente" (Haraway, 2008, p. 80). Isso vale tanto para os humanos, objeto do texto da filósofa, como para os animais imorais e irresponsáveis de Bekoff e de Waal. Do lado da humanidade, mesmo se fôssemos todos vegetarianos estritos e a abolição animal se realizasse, ainda mataríamos plantas para nos alimentarmos, talvez insetos que nos perturbassem ou destruíssem nossas plantações e outros. Muito menos do que hoje, claramente, mas ainda assim haveria muitas mortes - e a questão é esta: não existe inocência, tampouco devemos desejar ocupar esse lugar contra todo o resto dos viventes. Mas pode existir responsabilidade, a possibilidade de responder. Isso que chamei de dessacralização da morte, ideia proposta por Haraway, não é um salvo-conduto para assassinatos, hecatombes, holocaustos ou ecocídios; pelo contrário, é uma atitude que parte de situações concretas e realistas. Dizer que não há inocentes não implica que o exterminismo, 
em qualquer configuração que se exprima, não faça vítimas ou que seja justificado - isso significaria adentrar uma zona de indistinção, um achatamento e confusão de responsabilidades. A questão, outra, é: como viver em um mundo em que matar é necessário? A necessidade aí deve ser tomada com muito cuidado; quando, como, o que é necessário? A saída encontrada por Haraway passa por uma mudança do mandamento bíblico: e se, em vez de "não matarás", nos guiássemos pela injunção "não tornarás matável” (idem)? Em primeiro lugar, assassinatos em massa ou a transformação de qualquer espécie, povo ou grupo em matáveis seriam o verdadeiro interdito, um dos primeiros princípios. Isso não significaria que deveríamos deixar completamente de matar, mas poderia constituir uma saída para o exterminismo: por um lado, lobos e guepardos não seriam mais culpados e populações indígenas caçadoras não seriam perseguidas por seu modo de vida; por outro, o sistema de produção animal, a indústria de cobaias farmacêuticas, o tráfico desmesurado de animais e outras práticas certamente se tornariam moralmente insustentáveis. Os verdadeiros imorais viriam à luz ${ }^{59}$.

\subsection{2. \\ "Proliferação louca de formas"}

Para Massumi, como vimos, a possibilidade de uma política animal se desenvolve em torno da brincadeira, a atividade em que, de Bekoff a Bateson, se viu a realização de uma ação querendo significar outra. Segundo Massumi, o que está em jogo na mordida que denota outra coisa que não ela é uma "inclusão mútua" (Massumi, 2014, p. 4) da diferença, sua "não-coincidência", algo como um paradoxo: o terceiro incluído. Na brincadeira, ambos os participantes são levados a um lugar que não é mais aquele no qual se estava; há um certo modo, um estilo de morder que transporta qualitativamente os atores envolvidos, uma "transformação em lugar que não afeta um sem afetar o outro", isto é, “transindividual” (idem, p. 5). A brincadeira é então performance, o lugar em que

${ }^{59}$ Esclareço que este trabalho não tem a intenção de fazer uma crítica aos defensores dos direitos animais, responsáveis por muitas conquistas, tampouco a ninguém que dedique sua vida à causa da melhoria do tratamento dispensado aos animais. A breve discussão meramente ensejada aqui tem como objetivo apenas complicar certos argumentos e oferecer talvez um outro quadro conceitual possível no qual essas questões podem ser tratadas. 
o que se faz não é aquilo que é denotado, no qual o combate, que seria seu modelo e guia, aparece sempre de forma levemente alterada. Isto é, a brincadeira faz com que seus participantes entrem em uma zona de indiscernibilidade - não de indistinção - na qual as diferenças entre ela e o combate passariam de um a outro sem se apagar: "fundidas sem se tornarem confundidas" (idem, p. 6). Além disso, a alegria contida no modo análogo de ação constitui, segundo o filósofo, um excesso, um "afeto de vitalidade" (idem, p. 9); a mordiscada que denota a mordida - talvez a troca de olhares que convida e anima - em uma atividade sem propósito a não ser ela mesma seria pura expressão desse afeto. A brincadeira, assim, pertenceria "instintivamente à dimensão estética" (idem, p. 10).

Além disso, ainda que haja na brincadeira aprendizado e toda a série de funções anteriormente mencionadas, Massumi valoriza nela principalmente a variação e seu caráter de invenção e improviso. Mesmo que a brincadeira tenha por modelo o combate, é nela que o combate se inventa, refina, transforma-se. Quanto mais se brinca, mais se inventa; quanto mais se inventa, mais apto ao improviso se é tornado, ou seja, mais apto à vida mesma. A vida, assim, "se beneficia do valor excedente da vida produzido pela brincadeira, convertido em valor de sobrevivência" (idem, p. 12). Este seria um modo de a vida produzir a si mesma pelo excesso expressivo e não pela mera adaptação ao dado; a brincadeira, que imita o combate, é anterior a ele e o modifica. A abundância estética e não a adequação à penúria constituiriam o modo pelo qual a vida opera e se reproduz.

Massumi vê esse poder de improviso contido na brincadeira como fazendo parte do instinto. Ele parafraseia Raymond Ruyer: "se o ato instintivo fosse como é reputado ser - uma sequência estereotipada de ações pré-modeladas executadas por reflexo à maneira de um automatismo - então o instinto seria incapaz de responder às mudanças casuais no ambiente" (idem, p. 13). As variações ambientais devem encontrar variações comportamentais, ou seja, é inconcebível que o instinto seja uma reação e não uma resposta, plástica e criadora. Massumi chama esse poder do instinto de variar e responder de "poder de abstração" (idem, p. 14), uma reflexividade não ligada ao cérebro - estudos mostram que amebas têm memória e podem antecipar o futuro, e platelmintos, uma vez decapitados, continuam a se lembrar de tarefas aprendidas antes. Seria este "poder da mentalidade expressiva" (idem) o motor da evolução - uma ideia que Massumi credita a Bergson, Bateson e Ruyer - na medida em que qualquer mudança, 
mesmo uma provocada pelo acaso, encontra uma resposta criativa na forma de reconfiguração dos entes em conexão com aquilo que mudou. $\mathrm{O}$ instinto, assim, sempre superaria o dado, "sendo animado por um ímpeto imanente em direção ao supernormal" (idem, p. 15), conceito tomado emprestado do etólogo Nikolaas "Niko" Tinbergen.

Tinbergen, ao estudar a relação entre estímulo e comportamento, percebeu nos animais uma preferência pelo "supernormal", isto é, pela exacerbação do signo-estímulo direcionado a determinado comportamento. Seu exemplo-padrão veio de pesquisas com gaivotas prateadas (Larus argentatus), cujos filhotes, ao bicarem os bicos dos pais, os estimulam a regurgitar comida, alimentando-os. O bico das gaivotas adultas possui um pequeno círculo vermelho na parte inferior, e Tinbergen percebeu que era isso o que atraía os pequenos. Ele então conduziu uma série de experimentos nos quais usava modelos de cabeças de gaivotas, trocando a cor do círculo, e constatou que os filhotes eram mais atraídos por contraste e cor. Ou seja, confrontados com bicos contendo círculos pretos e vermelhos, eles escolhiam os pretos; com círculos de diversas cores, preferiam os vermelhos - estes últimos, concluiu o etólogo, proviam tanto o contraste necessário quanto a cor favorita ${ }^{60}$. Mas Tinbergen notou também outra coisa: uma resposta e até preferência pelo estímulo isolado e hiperbolizado. Os filhotes de gaivota respondiam até a uma haste vermelha com três círculos brancos - de fato, escolheram este modelo nada parecido com uma cabeça de gaivota $25 \%$ mais vezes que um bico de verdade (cf. Tinbergen, 1965, p. 67).

A este fenômeno ele chamou supernormalidade. Os cucos, que deixam seus ovos nos ninhos de outras aves para que estas criem seus filhotes, se aproveitariam dessa tendência; seus filhotes muitas vezes têm bicos bem maiores que os dos filhotes originais, e a preferência pelo supernormal faria com que os adultos de outras espécies os alimentassem, por vezes deixando os seus à míngua. Tinbergen chega mesmo a insinuar que certos pássaros não apenas se inclinam a alimentar os filhotes do cuco, mas "amam" fazê-lo "porque os cucos oferecem uma boca enorme e convidativa" (Tinbergen, 1968, p. 67). O mesmo se aplicaria a

${ }^{60}$ Em 2009, o biólogo comportamental Carel ten Cate replicou e incrementou os experimentos de Tinbergen por suspeitar que suas inferências não estivessem de acordo com os métodos e resultados, e concluiu que "apesar de sua abordagem ser questionável, as intuições de Tinbergen mostraram-se certas e seus dados, corrigidos, apresentam uma correspondência razoável ao que um experimento real teria provido" (ten Cate, 2009b, p. 802; cf. também ten Cate, 2009a). 
mariposas cujas asas imitam não apenas um, mas dois pares de olhos: "para os pássaros que os predam este arranjo supernormal pode ser mais apavorante que um conjunto normal de olhos" (idem).

Massumi interpreta essa preferência pela intensificação como uma "topologia da experiência na qual diversos elementos em jogo são arrastados conjuntamente em direção à sua própria variação integral, em um estado dinâmico de inclusão mútua" (Massumi, 2014, p. 16). Embora Tinbergen tenha feito tal descoberta, diz o filósofo, isso não foi suficiente para fazê-lo abandonar as comparações entre animais e máquinas. Ele exprime entretanto uma ponta de frustração ao notar a própria incapacidade de explicar totalmente suas complexas máquinas; a supernormalidade, que envolve estímulos "relacionais" e "configuracionais", parece "ser mais a regra que a exceção" e, embora "até hoje ninguém tenha sido capaz de analisar esses assuntos; ainda assim, de alguma forma [somehow] eles são realizados" (Tinbergen, 1985, p. 68). Para Massumi, que cita essa frase de Tinbergen, "é precisamente o 'de alguma forma' desta realização dos filhotes de pássaro que frustra as expectativas aprendidas pelo cientista que deve ser retido e integrado a nossas noções de animalidade" (Massumi, 2014, p. 16).

O filósofo propõe assim o entendimento da supernormalidade instintiva como um poder mental: "a capacidade de superar o dado ${ }^{61}$ " (idem, p. 17). A preferência pelo supernormal não configuraria, nos filhotes de gaivota, um tipo de reconhecimento do signo-estímulo círculo vermelho, mas a produção espontânea de "blocos de sensações" (idem, p. 17), no sentido de Deleuze e Guattari ${ }^{62}$. As características do instinto seriam, então, improviso, criação, espontaneidade,

${ }^{61} \mathrm{O}$ tipo de mentalidade a que Massumi se refere neste ponto inspira-se na interpretação deleuziana de Hume, além de Ruyer e de Whitehead (cf. Massumi, 2014, p. 102-103).

${ }^{62} \mathrm{Em} O$ que é a filosofia?, os autores explicam que aquilo que denominam blocos de sensação diz respeito à arte, que é a "linguagem das sensações" e que não tem "opinião", o que "desfaz a tríplice organização das percepções, afeç̧ões e opiniões, substituindo-as por um monumento composto de perceptos, de afectos e de blocos de sensações que fazem as vezes de linguagem" (Deleuze e Guattari, 2009, p. 228). A arte, ainda, segundo os autores, "começa talvez no animal" (idem, p. 237): "O Scenopoietes dentirostris, pássaro das florestas chuvosas da Austrália, faz cair da árvore as folhas que corta cada manhã, vira-as para que sua face interna mais pálida contraste com a terra, constrói para si assim uma cena como um ready-made, e canta exatamente em cima, sobre um cipó ou um galho, um canto complexo composto de suas próprias notas e das de outros pássaros, que imita nos intervalos, mostrando a raiz amarela das plumas sob seu bico: é um artista completo. Não são as sinestesias em plena carne, são estes blocos de sensações no território, cores, posturas e sons, que esboçam uma obra de arte total" (idem, p. 238). 
excesso e paixão (os pássaros amam dar de comer aos filhotes de $\operatorname{cucos}^{63}$ ). Longe de poder ser descrito em termos mecânicos, o supernormal leva a experiência, cada experiência, para além de si mesma, a seu limite - e assim a uma nova experiência: a preferência dos filhotes de gaivota pelo hiperbólico pode efetivamente transformar e criar novas relações com seus pais. Isto é, a tendência supernormal é parte criativa da evolução; a adaptação é um jogo experimental entre condições dadas, ou melhor, co-criadas por outros entes ${ }^{64}$, e apetites pelo supernormal, o que explicaria a "proliferação louca de formas tão férteis que desafiam a imaginação humana" (idem, p. 21). Lynn Margulis e Dorion Sagan, em $O$ que é vida?, respondem à pergunta do título de muitos modos. Um deles é que a vida é "a matéria desenfreada [matter gone wild], capaz de escolher sua própria direção para prevenir indefinidamente o momento inevitável do equilíbrio termodinâmico - a morte" (Margulis e Sagan, 2002, p. 66). "Louca" e "selvagem" são dois adjetivos, nesse sentido, capazes de exprimir os modos pelos quais a vida se co-inventa e mantém.

Uma filosofia da natureza, assim, continua Massumi, precisaria abordar o caráter intensamente expressivo e imaginativo da vida. Essa conclusão faz com que ele retorne então à brincadeira e a sua relação com o mapa e o território antevista por Bateson. A brincadeira deve ser compreendida como uma "cartografia ativa" [enactive cartography] que "cria o território que mapeia em novas variações emergentes sobre uma arena existente de atividade" (Massumi, 2014, p. 23), na medida em que o improviso e a supernormalidade podem vir a inventar novas formas de práticas mundanas que aumentem as possibilidades de sobrevivência de determinado animal. Assim, o mapa-brincadeira, fruto de um

${ }^{63}$ Massumi aí se aproxima do que Whitehead chamava apetição, conceito por sua vez inspirado na monadologia leibniziana: "Toda experiência física é acompanhada por um apetite por ou contra sua continuidade: um exemplo é a apetição da autopreservação. Mas a origem da preensão conceitual da novidade deve ser levada em conta. A sede é um apetite em direção a uma diferença - em direção a algo relevante, algo largamente idêntico mas com uma novidade definida. Este é um exemplo de baixo nível que mostra o germe de uma imaginação livre" (Whitehead, 1978, p. 32).

${ }^{64}$ De acordo com a teoria de Gaia, de James Lovelock, em coautoria com Lynn Margulis, "logo depois que a vida começou, tomou controle do ambiente planetário e [...] essa homeostase de e pela biosfera persiste desde então" (Lovelock e Margulis, 1974, p. 2); "a temperatura do planeta, o estado de oxidação e outras químicas de todos os gases da baixa atmosfera (exceto o hélio, o argônio e os não reativos) são produzidos e mantidos pela soma da vida" (Margulis, 1996, p. 139), isto é, as condições da vida são dadas pela própria vida em um grande sistema biogeofísico - em suas múltiplas formas. Trata-se da "atmosfera como artifício" (Lovelock e Margulis, 1974, p. 5). Pensando a partir de Gaia, então, mesmo as condições dadas para a adaptação da vida são, em alguma medida, produzidas pela vida. 
expressivo poder mental, seria um agente modificador do território-físico: tanto as bicadas do filhote de gaivota prateada, sugere Massumi, podem vir a modificar a própria estrutura física do ninho que habitam, como o próprio território seria o resultado sempre variável de uma zona de indiscernibilidade entre brincadeira e combate.

Em vocabulário deleuziano, poder-se-ia dizer: brincadeira $E$ combate, “o e como extra-ser, inter-ser", aquilo "que subentende todas as relações, a estrada de todas as relações e que faz com que as relações corram para fora de seus termos e para fora do conjunto de seus termos", "um pensamento totalmente extraordinário e [que] é, no entanto, a vida (Deleuze e Parnet, 1998, p. 47). O outro "e" da brincadeira é aquele que envolve seus participantes, tornando-a trans-situacional e transindividual - não há modificação que não toque ao mesmo tempo todos os que brincam:

No movimento da brincadeira, territórios existenciais ${ }^{65}$ se cruzam e se modulam mutuamente através de sua diferença, arrastados na direção de expressões novas de suas formas dinâmicas, cada novo movimento-da-brincadeira tendo o valor de um movimento-de-luta em potencial improvisacional (Massumi, 2014, p. 27).

Repetindo Bergson, Massumi então afirma que instinto é simpatia. Em L'Évolution Créatrice, Bergson dá como exemplo a intenção do artista que, "por uma espécie de simpatia" e um "esforço de intuição", é capaz de se colocar "no interior do objeto" e diminuir o espaço entre ambos (Bergson, 1909, p. 192). Anos depois, em La Pensée et le Mouvant, o filósofo voltaria a dar uma definição muito parecida, propondo que "nós chamamos aqui de intuição a simpatia pela qual alguém é transportado ao interior de um objeto de modo a coincidir com aquilo que é único e consequentemente inexprimível nele" (Bergson apud Massumi, 2014, p. 32). Em lugar de objeto, entretanto, Massumi diz "evento" - um modo de escapar da dualidade sujeito/objeto e do caráter pronto de um objeto, assim reinserindo a simpatia em um campo transindividual: a simpatia "é o modo de

65 "Território existencial" é um conceito de Guattari a que ele se dedica sobretudo em Caosmose, mas também em As três ecologias e em uma série de artigos e entrevistas (cf. Guattari, 1995; 2009; 2011). Massumi o define como "mais abrangente que o de território no sentido estrito. Refere-se ao território no sentido físico mas também toma formas dinâmicas, formas de atividade que usam o território como fonte de devir. Inclui ainda as relações mentais entre territórios em jogo [in play] e entre as formas dinâmicas que o território hospeda. O território existencial é um bloco de espaço-tempo vivido no qual a vida se pensa a si mesma à medida que desempenha a variação [as it plays variation]. O conceito de território existencial também, e de modo específico, refere-se à composição estilística de atividades vitais, incluindo os vaivéns entre arenas díspares, efetuando uma modulação recíproca dessas arenas, de modo a potencialmente prolongá-las evolutivamente" (Massumi, 2014, p. 24). 
existência do terceiro incluído" (Massumi, 2014, p. 35). É todo este complexo que se efetua quando pelo menos dois animais brincam.

Este arcabouço conceitual possibilitaria a criação de um "paradigma éticoestético de política natural” (idem, p. 38), diz Massumi, tomando emprestado um termo de Guattari, ou ainda, em suas próprias palavras, uma política animal. Ele, então, delineia quatorze diretrizes - "preliminares, a serem completadas de acordo com o apetite" (idem) que lhe permitem urdir uma ideia de política: $1^{\text {o }}$ ) que devolve o humano ao contínuo da vida como animal com instinto; $2^{\circ}$ ) que não pode ser normativa, tendo que sempre superar o dado em cada situação; $3^{\circ}$ ) que não opõe o sério ao frívolo pois compreende que mesmo o que não tem função, como a brincadeira, é parte do processo pelo qual a vida cria e se transforma; $4^{\circ}$ ) que não é representacional, mas performativa; $5^{\circ}$ ) que abandona o conceito de agência em favor de processos de devir transindividuais; $6^{\circ}$ ) cujo critério éticoestético é afetivo e se encontra na inclusão mútua do não ainda expresso e do que já o é, assim como na brincadeira; $7^{\circ}$ ) que é sempre relacional - o afeto se dá sempre entre pelo menos dois - e transindividual, ou seja, que abraça o terceiro incluído; $8^{\circ}$ ) que é totalmente situada sem ser contextualizada - ou seja, que singular e não particular -, in-formando (formando-se por dentro) em vez de conformar-se (aplicar o particular ao geral); $9^{\circ}$ ) que diz respeito ao gesto nãoverbal da brincadeira e faz a linguagem brincar, usando-a instintivamente; $10^{\circ} \mathrm{e}$ $11^{\circ}$ ) que abraça a inclusão mútua especulativa e pragmaticamente; $12^{\circ}$ ) que é uma política do devir; $13^{\circ}$ ) que não teme o antropomorfismo baseado em múltiplas diferenciações mas sem abraçar o grande divisor humanidade/animalidade e é "animocentrada" (idem, p. 52); 14 ) e, finalmente, que "não teme o instinto" (idem, p. 54).

A política proposta por Massumi é menos uma política com os animais que uma política que devolve o humano ao continuum da vida enquanto um animal não é por acaso que seu livro se intitula $O$ que os animais podem nos ensinar sobre política. O pronome "nos" insere a humanidade na vida como um lugar em que trocas são possíveis (e até mesmo ensinamentos), ao mesmo tempo em que diferencia humanos de animais. Nesse sentido, não se trata, para ele, de abolir as duplas natureza-cultura / humanidade-animalidade, mas de sair de seu dualismo em direção à intensificação de seu contínuo, "para inventar movimentos 
irrepresentáveis de singularização constituindo uma democracia revolucionária no ato" (idem, p. 108).

É curioso que o filósofo faça apelo à democracia neste ponto, única ocorrência da palavra em todo o livro, justamente em uma nota em que pretende se afastar de Latour e sua ideia de mundo comum constituído por um "Parlamento das Coisas" ${ }^{\circ 6}$. A crítica se baseia no caráter representativo de uma instituição como um parlamento - afinal, a política animal se afastaria da representação mas não explicita o caráter de seu próprio conceito de “democracia revolucionária." De que democracia Massumi fala? As modernas, representativas, não são as melhores candidatas para ocupar esse lugar; talvez a platônica, mencionada em nosso primeiro capítulo, com seu "transbordamento de liberdade" e "temperamento anárquico", recuperada em um estranho movimento de inversão valorativa. $\mathrm{O}$ autor tampouco indica como os outros animais poderiam tomar parte, transindivual e transespecificamente, nessa política. É certo que o seu conceito de política animal não é normativo e deve superar o dado em cada evento de modo situado, não podendo postular portanto regras de ação, mas apenas diretrizes - sempre incompletas, como ele lembra. Mas talvez por isso mesmo pareça fora de tom a invocação da democracia como finalidade - ainda que revolucionária, o que poderia ser interpretado como em devir, ou seja, jamais pronta, antes como "geografia, [...] orientações, direções, entradas e saídas" (Deleuze e Parnet, 1998, p. 2) ${ }^{67}$. O filósofo poderia, quem sabe, ter falado em

66 Em Jamais fomos modernos, Latour propõe, como um dos "herdeiros das Luzes" (Latour, 1994, p. 140) que as deseja "sem a modernidade" (idem, p. 17), este Parlamento, uma "democracia estendida às coisas" (idem), criada pela recomposição da "continuidade do coletivo" (idem, p. 142) como substituto da Constituição bicameral moderna que separa natureza de sociedade: "Não há mais verdades nuas, mas também não há mais cidadãos nus. Os mediadores dispõem de todo o espaço. As Luzes encontraram enfim seu lugar. As naturezas estão presentes, mas com seus representantes, os cientistas, que falam em seu nome. As sociedades estão presentes, mas com os objetos que as sustentam desde sempre" (idem, p. 142). O caminho até esse parlamento tem um caráter não revolucionário, mas de reforma: "Não teremos que criar este Parlamento passo a passo, apelando para mais uma revolução. Temos simplesmente que homologar aquilo que todos nós fazemos desde sempre, contanto que repensemos nosso passado, que sejamos capazes de compreender retrospectivamente o quanto nós jamais fomos modernos, e que juntemos as duas metades deste símbolo partido [a política, partida entre as ciências e técnicas, e a sociedade]" (idem), afirmando deixar a outros a composição deste parlamento.

${ }^{67} \mathrm{Em} O$ que é a filosofia?, Deleuze e Guattari afirmam que "as democracias são maiorias, mas um devir é por natureza o que se subtrai sempre à maioria” (Deleuze e Guattari, 2009, p. 140141), e a criticam em sua forma Estado: "Quem pode manter e gerar a miséria e a desterritorialização-reterritorialização das favelas, salvo polícias e exércitos poderosos que coexistem com as democracias? Que social-democracia não dá a ordem de atirar quando a miséria sai de seu território ou gueto?" (idem, p. 138); mas aventam a possibilidade de "um devirdemocrático que não se confunde com o que são os Estados de direito” (idem, p. 145). 
devires-revolucionários se reterritorializando em mundos co-constituídos e florescentes, como um modo de escapar ao conceito de democracia, tão ligado à forma Estado. Lembremos que em uma entrevista a Antonio Negri publicada em Conversações, Deleuze disse que "não há Estado democrático que não esteja totalmente comprometido nesta fabricação da miséria humana" (Deleuze, 2004, p. 213); a esta afirmação poder-se-ia acrescentar a miséria outra-que-humana. Em que sentido, então, e diante de quem Massumi fala em democracia?

Mesmo resvalando em um vocabulário da política humana ao invocar uma obscura ideia de democracia, Massumi demonstra uma preocupação constante com a "desumanização" da humanidade com vistas a uma nova política. What animals teach us about politics dirige-se aos humanos, ou melhor, a certos humanos - aqueles investidos no antropocentrismo patológico contido na política tradicional. A obra parece ter um objetivo terapêutico, procurando recolocar a política (e a humanidade) no mundo e assim liberá-la das grades que a barram da vida e do devir. Massumi lembra a todo momento que o extra-humano não se encontra fora, mas que nunca houve o propriamente humano - além de fazer parte da animalidade, a humanidade é, em sua constituição, mais- ou outra-que-humana:

Pense apenas no modo pelo qual o "cérebro intestino" do sistema nervoso entérico modula experiência consciente, ou nas inflexões de fundo do afeto pelos hormônios, ou na orientação fluente da experiência pelo sistema proprioceptivo ou na aprendizagem do que é chamado "memória muscular" ou, mais no ponto deste ensaio, no instinto (idem, p. 93).

Citando o filósofo David Lapoujade a respeito de Bergson, o autor exorta: "Lembrem-se: 'no coração do humano, não há nada de humano"” (idem), em um momento que faz recordar a transformação que Haraway opera no título do livro de Latour em When Species Meet: "jamais fomos humanos” (cf. Haraway, 2008). O livro de Massumi, com seu arsenal transdisciplinar que mobiliza conceitos hauridos da filosofia e da etologia para imaginar uma nova forma de política, explora um dos caminhos abertos pela promessa da brincadeira animal em seu excesso expressivo e criador e é ainda uma das respostas possíveis às questões que a filósofa faria em 2016 a respeito de como agir e pensar diante da catástrofe ambiental:

$\mathrm{O}$ que acontece quando a excepcionalidade humana e o individualismo circunscrito, esses velhos clichês da filosofia ocidental e da política econômica, tornam-se impensáveis nas melhores ciências, sejam naturais ou sociais? Seriamente impensáveis: não disponíveis para se pensar junto (Haraway, 2016c, $\mathrm{s} / \mathrm{p})$. 


\section{8. Política animal}

No capítulo sobre o instinto de On the Origin of Species, Darwin dedica uma seção a certas espécies de formiga, a saber, Polyergus rufescens e Formica sanguinea, conhecidas por parasitar espécies do gênero Formica - sendo que nas primeiras, por terem desenvolvido uma mandíbula que as impede de se alimentar ou cuidar de seus filhotes sozinhas, o parasitismo é obrigatório, mas não nas segundas. Ambas as formigas roubam as pupas de suas presas e, por meio de complexas operações que envolvem congruência de odor, as fazem realizar tarefas diversas. Darwin chama a seção de "instinto escravagista", comentando que procurou observar as formigas ele mesmo com uma "mentalidade cética, já que qualquer um pode ser desculpado por duvidar da verdade de um instinto tão extraordinário ou odioso quanto aquele de fazer escravos" (Darwin, 1859, p. 220). Embora não se sinta capaz de conjecturar acerca dos processos que levaram a esse tipo de relação entre formigas, ele afirma que "não vê dificuldade em a seleção natural aumentar e modificar o instinto - supondo que cada modificação deva ser útil para a espécie - até que uma formiga se tenha tornado abjetamente dependente de seus escravos" (idem, p. 224).

Das quase 15 mil espécies de formigas conhecidas, a dulose (do

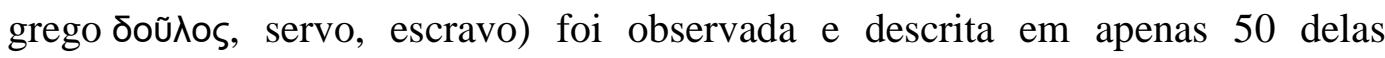
aproximadamente (cf. Sekhar, 2015), sendo por isso considerada "uma das relações interespecíficas mais incomuns no mundo animal" (Czechowski e Godzinska, 2015, p. 9). Ainda assim, as formigas costumam figurar como exemplos de tirania entre os animais, de sua imoralidade ou da brutalidade do mundo natural. Uma série de estudos recentes mostra que as formigas cativas desenvolvem uma coleção de estratégias contra suas hospedeiras, como agressão física, tentativa de reprodução dentro da colônia, sabotagem contra ovos e pupas, que podem chegar a uma mortalidade de mais de 70\%, e mesmo emancipação (cf. Achenbach e Foitzik, 2009; Pamminger et alii, 2012; Czechowski e Godzinska, 2015), complicando os modos pelos quais essas relações são compreendidas. $\mathrm{Na}$ conclusão de "Enslaved ants: not as helpless as they were thought to be", Czechowski e Godzinska exprimem a "esperança" de terem "demonstrado de 
modo convincente que as formigas escravizadas não são tão indefesas como se pensava e podem se defender contra a exploração das escravizadoras de muitos modos diferentes" (Czechowski e Godzinska, 2015, p. 19).

A zoóloga Joan M. Herbers, que por muitos anos estudou evolução social de formigas, manifestou em 2007 um desagrado em relação à linguagem usada para se referir à dulose; diversas vezes, conta, ela foi questionada sobre a ligação entre a escravidão entre formigas e a escravidão humana, como se a primeira de algum modo informasse a segunda, um tipo de rudimento natural que explicaria a prática na humanidade; como se a existência de escravidão entre formigas, na medida em que estas são formas mais primitivas de vida e totalmente inseridas na natureza, justificasse a escravização como algo natural, um instinto no sentido de mecanismo originário latente. Ademais, ela prossegue, a imagem da escravidão para descrever o comportamento de determinadas espécies de formigas levou à criação e ao uso do termo racista "negro ant" em referência à Formica Fusca, em uma operação de naturalização e indistinção que apaga tanto as diferenças entre formigas e povos negros escravizados ao mesmo tempo que naturaliza ou biologiza a servidão. Herbers dá como exemplo a troca do termo "estupro" por "cópula forçada" para descrever certos comportamentos de animais outros que humanos e postula a substituição do vocabulário da escravidão por outro, segundo ela também imperfeito mas menos nefasto, o da pirataria: "de minha parte, prefiro que as audiências identifiquem meu trabalho a Jack Sparrow antes que a Simon Legree" (Herbers, 2007, p. 105), fazendo referência ao simpático pirata interpretado por Johnny Depp na série de blockbusters Piratas do Caribe e ao cruel senhor de escravos do romance Uncle Tom's Cabin.

Como justificativa final, Herbers compara a instituição da escravidão, sobretudo na história recente do ocidente, com a relação entre as formigas, que

não reproduzem nem leiloam suas cativas. Rainhas parasitas recém fertilizadas devem invadir e tomar uma colônia estabelecida para assegurar a força de trabalho necessária para o cuidado de seus ovos; este comportamento de invasão não tem contraponto na escravidão humana (idem).

De Waal comenta que, no caso de uma família tão distante dos humanos quanto a Formicidae, chamar as formigas que habitam uma colônia de rainhas, soldados, trabalhadoras - ou escravas - não é senão uma "estenografia antropomórfica", isto é, quase um código resumido destinado a significar outra coisa. Esta não é uma crítica ao antropomorfismo, de que de Waal na verdade é um defensor, mas ao 
esgarçamento de significado que ocorre ao se projetarem instituições tão peculiares - e afinal pouco afins - como monarquia e militarismo em animais que não vivem nenhuma delas. Chamar uma formiga de rainha pode até funcionar como estenografia, mas essas fêmeas, que passam a vida se reproduzindo para povoar a colônia e, ademais, podem ser muitas na mesma comunidade, não poderiam existir de modo mais diferente do que, digamos, uma Maria Antonieta embora até possam vir a morrer decapitadas. Não se trataria, assim, de um antropomorfismo, passível de crítica, como costuma ser, pela atribuição exageradamente generosa de competências aos animais, mas quase de um tipo de jargão - mas mesmo esse tipo de jargão, se esquece de Waal, não é sempre inconsequente, como mostra a expressão "negro ant".

É portanto à acusação de antropomorfismo, feita quando um animal é referido como possuindo capacidades interessantes e análogas ou iguais às humanas, que o primatólogo dirige suas armas. Muito menos antropomórficos do que deveríamos ser diante da miríade de caracteres que compartilhamos com os animais, vivemos, segundo ele, em antroponegação (anthropondenial), "a rejeição a priori de traços humanos nos animais ou de traços animais em nós" (de Waal, 2016, p. 25). Seu exemplo preferido diz respeito à atribuição do riso a parentes próximos da humanidade, aquele dos jovens primatas outros que humanos em resposta a cócegas:

Não se pode simplesmente descartar o termo riso para este comportamento como sendo muito antropomórfico (como fizeram alguns), pois os primatas não apenas soam como crianças humanas em quem se fazem cócegas, eles mostram a mesma ambivalência em relação a elas quanto as crianças (idem).

Nesse caso, ele continua, não chamar de risada o que esses primatas fazem só seria possível caso se pudesse demonstrar que, ao gargalhar, os animais estariam em um estado mental diferente dos humanos, invertendo o fardo da prova comumente usado em seu prejuízo. Para ele, "ausente a evidência", seguindo o lema da ciência experimental, "riso me parece a melhor denominação para ambos" (idem):

Barreiras linguísticas injustificadas fragmentam a unidade que a natureza nos apresenta. Humanos e macacos [apes] não tiveram tempo suficiente para desenvolverem um comportamento tão surpreendentemente similar como o contato labial para saudação ou respiração ruidosa em resposta a cócegas. Nossa terminologia deve honrar as óbvias conexões evolutivas (idem, p. 26). 
Seu elogio do antropomorfismo como método de formulação de boas questões para e sobre os animais não supõe, por sua vez, uma identificação simples. Macacos rhesus mostram seus dentes como um sinal de submissão, chimpanzés correm uns em direção a outros grunhindo para se saudarem (cf. de Waal, 2001). Descrever esses comportamentos de modo puramente mecânico, como meras reações, seria antroponegacionismo. Dotar os animais de capacidade de resposta e identificar o primeiro comportamento a um sorriso e o segundo a agressão, seria "antropomorfismo antropocêntrico", aquele que opera projetando a si mesmo no mundo. O tipo de antropomorfismo a que de Waal se filia, por outro lado, é aquele que procura tomar a perspectiva dos animais observados em um exercício de habitação de seu mundo e que ele chama de "antropomorfismo animalcêntrico" (idem, p. 869).

Seguindo essa classificação, recusar um tipo de política às formigas poderia ser antroponegacionismo ${ }^{68}$; chamar seu mundo de escravagista (ou usar termos como "negro ant"), seria antropomorfismo antropocêntrico (e racista). Resta então o antropomorfismo animalcêntrico, que procure imaginar o mundo das formigas desde dentro, com suas invenções, possibilidades e resistências. Não se trata de adotar um modelo imutável, igualitário ou moralmente bom segundo os critérios ocidentais, mas de sair do paradigma da "natureza vermelha nas garras e nos dentes", que recusa qualquer traço considerado positivo aos animais enquanto aceita prontamente sua "bestialidade." Animais podem ser e são muitas vezes violentos uns com os outros - mas isso não é tudo. É um fato que algumas espécies de formigas atacam formigueiros e mantêm indivíduos de outras espécies em suas colônias, trabalhando ali para elas; também é um fato que essas formigas capturadas podem ou não aceitar sua condição, muitas vezes rebelando-se, como dizem os entomólogos. Todo cuidado é necessário nessas questões; defender que escravidão talvez não seja o melhor nome para a relação de parasitismo de certas formigas também pode facilmente levar a um relativismo absoluto que desconsidera os contínuos e as misturas que há por toda parte, culminando em um discurso de incomensurabilidade entre mundos ou, pior, de separação entre

${ }^{68}$ É possível que de Waal discordasse desta afirmação, considerando que as formigas estão muito distantes dos humanos para que se as dote de uma política; por outro lado, a sua intensa socialidade talvez tornasse irresistível, para o primatólogo, a atribuição a elas de uma política. De todo modo, as formigas só costumam aparecer em sua obra nas narrativas sobre as técnicas desenvolvidas por primatas para apanhá-las. 
humanidade e animalidade. Não é o caso. O trabalho deve ser outro e mais minucioso: "começar a permitir termos como amizade e a testar de modo mais cuidadoso termos que soam mais científicos (agressão) pelo trabalho invisível que eles de fato fazem ao modelar o que os cientistas sabem como ver" (Haraway, 2008, p. 375). No caso dessas formigas, agressão parece um termo muito mais apropriado que amizade para descrever suas relações. Mas a questão é outra: "o ponto é prestar atenção comparável e ter hipóteses testáveis para todo o espectro" (Haraway, 2008, p. 375). Então: escravidão, pirataria ou...? Hipóteses testáveis certamente requerem imaginação e simpatia, além de muito trabalho; a história das formigas rebeldes, que só recentemente começou a ser contada, talvez contenha uma promessa.

O biólogo Dave Mech, especialista em lobos, escreveu em 1968 um livro que se tornou célebre, The Wolf. The Ecology and Behavior of an Endangered Species, no qual repetia um argumento considerado definitivo a respeito da organização das alcateias: que estas, embora sua liderança estivesse sempre em questão, eram chefiadas por um macho alfa e uma fêmea alfa. Porém, depois de 13 anos (de 1986 a 1998) observando no campo a mesma alcateia, a Ellesmere Island pack, ele percebeu algo assombroso: que os lobos, afinal, não eram dominados por indivíduos cuja agressividade e força superior os mantinham, por meio de lutas, em seu posto, mas que seus líderes eram simplesmente aqueles que se reproduzem, ou seja, os pais e as mães da alcateia. Acontece que até ali nenhum trabalho extenso de observação do mesmo grupo em seu território havia sido feito e todos os dados disponíveis vinham de lobos em cativeiros, ou seja, animais que não possuíam laços de parentesco, restando-lhes a agressividade como estratégia organizacional. Em seu habitat, sem as restrições espaciais e o convívio forçado do confinamento, o que os lobos mostraram a Mech foi

que a alcateia típica [...] deve ser vista como uma família, com os pais adultos guiando as atividades do grupo e compartilhando a liderança do grupo em um sistema de divisão de trabalho no qual a fêmea predomina primariamente em atividades como cuidado dos filhotes e defesa e o macho primariamente forrageando, provendo comida e as viagens associadas a elas (Mech, 1999, p. 1202).

Os termos "macho alfa" e "fêmea alfa" deram então lugar a outros como "progenitor", "progenitora", "macho reprodutivo" e "fêmea reprodutiva". O biólogo explica que "o ponto aqui não é tanto a terminologia, mas o que a 
terminologia falsamente infere: uma hierarquia rígida baseada na força" (idem, p. 1198). Mas é justamente essa inferência que torna a terminologia nociva; "alfa" não chega perto de descrever a organização dos lobos e, por um lado, mantém uma imagem vil e tirânica desses animais; por outro, se dissemina de modo insidioso em discursos humanos (pense-se, por exemplo, em toda a violência gerada pela apropriação política do termo "macho alfa"). "O homem é o lobo do homem", a celebérrima fórmula imortalizada por Hobbes, por exemplo, ao mesmo tempo em que degrada os lobos, justifica uma política humana opressora. E foi somente se engajando ativamente com esses animais, em um tipo de pesquisa corporificada (cf. Despret, 2010) e aberta ao que eles poderiam lhe dizer, convivendo com lobos por mais de dez anos em seu território, que Mech pôde finalmente ter acesso ao segredo daqueles cujos olhos ardem num "altivo fogo verde" (Leopold, 2008, p. 130), cujos uivos são "a erupção de uma dor selvagem e desafiadora" (idem, p. 128), que talvez só as montanhas conhecessem até ali: as famílias lupinas.

Quando Shirley Strum partiu para o Quênia em 1972, ela conta, interessavase pela continuidade entre humanos e primatas outros que humanos. Muitos cientistas da época, segundo ela, acreditavam possuir já a chave da evolução e sustentavam o credo de que éramos os bisnetos de espécies agressivas que viviam em grupos pequenos e coesos, dominados por machos em constante e violenta disputa pela liderança, e cujas fêmeas resignavam-se em ser sua parte passiva, cuidando de bebês, sem a necessidade, portanto, de "habilidades políticas masculinas" (idem, p. 7). Embora nenhum de nossos ancestrais vivesse então na África, tínhamos ali parentes bem próximos que serviam para esse tipo de pesquisa, e Strum foi estudar os babuínos-anúbis (Papio anubis), que, assim como os primeiros humanos, habitam savanas - algo muito incomum entre primatas. A primatóloga carregava consigo a esperança de observar melhor as fêmeas e crianças do bando, até ali negligenciadas, segundo sua opinião; talvez elas fossem mais interessantes do que a literatura tradicional até ali supunha; talvez os babuínos não fossem tão violentos.

Quando o trabalho de fato começou e Strum foi levada até a gangue, foi aconselhada a observá-los apenas à distância, através de binóculos, como seus colegas: "tinha o sinistro sentimento de ser uma Peeping Tom" (idem, p. 18), ela comenta. Aos poucos e sozinha, finalmente conseguiu se aproximar dos babuínos 
a ponto de caminhar por entre eles - mas sem jamais tocá-los, mantendo-se fora de seu círculo social. O que o seu trabalho de campo, que hoje é provavelmente o mais longevo do tipo, contando com mais de 40 anos, revelou foi quase o avesso do modelo patriarcal e sanguinário: babuínos são matrilineares e seus grupos construídos em torno das fêmeas - os machos vêm e vão -, as negociações, inclusive sobre a natureza do grupo, são intensas (Strum menciona uma fusão entre grupos cuja negociação durou dois anos), a amizade entre machos e fêmeas e entre machos e filhotes é cultivada e desempenha importante papel na resolução de conflitos e na cooperação, não há chefe individual, mas a influência de um indivíduo varia segundo características suas (idade, tamanho, conhecimento, força) e o contexto, e a agressão é incomum - de fato, segundo Strum, os babuínos que se agridem o fazem de modo quase coreografado, como em uma dança, e ao fim desses combates não costumam estar muito machucados (cf. Strum, 1987; 1998; 2012). Ela também os observou brincar. Como notou Strum, essa atividade é acompanhada de uma "cara de brincadeira", que exprime "a importante mensagem: Isto não é sério, embora pareça" (idem, p. 272).

Então, o que é política? É uma multiplicidade irredutível de modos de coabitar e co-constituir o mundo diferente e assimetricamente; é compreender que só existem políticas cósmicas, ainda que em negação, isto é, que toda política diz respeito a mais que um grupo, mais de um povo ou espécie, ainda que se denegue nela a participação passiva e/ou ativa desses outros; é a saúde do instinto; é um jogo ou uma brincadeira não-inocente que diz respeito à diferença entre fair play e bullying; é habitar o perigo de que esta brincadeira se torne combate; é evitar tomar por objetos-brinquedos seres que poderiam agir como sujeitos-jogadores; é um modo mutante de criação e uso de mundos no sentido de mapa e território que depende sempre de mais de um para que se entre em uma zona de indiscernibilidade que gesta consequências concretas para todos os envolvidos. 


\section{4 \\ Experimentais}

4.1.

Arte

4.1.1.

Rotpeter e Consul

Logo nas primeiras páginas de Kafka: Pour une littérature mineur, Deleuze e Guattari informam ao leitor que não pretendem tratar da obra do escritor em termos interpretativos ou procurando encontrar nela arquétipos ou estruturas, e expõem uma espécie de declaração de princípios que os guiará em sua leitura:

Não cremos senão em uma política de Kafka, que não é nem imaginária nem simbólica. Não cremos senão em uma ou mais máquinas de Kafka, que não são nem estrutura nem fantasma. Não cremos senão em uma experimentação de Kafka, sem interpretação nem significado, mas somente protocolos de experiência (Deleuze e Guattari, 1975, p. 14).

Em seguida, para reforçar ou ilustrar tais crenças, os autores citam uma passagem de "Relatório a uma academia", conto de Kafka no qual o narrador, um exmacaco, encerra sua exposição alegando não querer o "julgamento dos homens", satisfazendo-se em "difundir conhecimentos" e relatar (Kafka, 1994, p.67). É Rotpeter, ou Pedro Vermelho na tradução de Modesto Carone, quem fala, e é ele que, além de prover Deleuze e Guattari com talvez o próprio método por meio do qual adentrar a obra de Kafka, vai enunciar um dos conceitos mais importantes do livro, o de saída (issue, em francês): “a possibilidade de uma saída por onde escapar, uma linha de fuga" (Deleuze e Guattari, 1975, p. 23). Um dos sentidos da política na literatura de Kafka diz respeito à possibilidade fazer fugir ou escapar uma situação, não de uma situação; em lugar de compreender a obra do escritor como crítica, que para os autores se encontraria no nível da representação - do lado de fora ou de dentro, no sentido de uma crítica do mundo ou de uma autocrítica (cf. idem, p. 85) -, para eles 'Kafka não fugia para 'fora do mundo', era antes o mundo e a sua representação que ele fazia vazar (no sentido de um cano que vaza) e que ele enredava nessas linhas" (idem). Em "Micropolítica e 
segmentaridade", de Mil Platôs, os autores asseveram que "tudo é político, mas toda política é ao mesmo tempo macropolítica e micropolítica" (Deleuze e Guattari, 2004, p. 90), o que significa que todos estão atravessados ao mesmo tempo por segmentaridades molares e moleculares ${ }^{69}$. O exemplo que eles dão ali advém do que chamam de os "grandes conjuntos binários", como "os dois sexos", que "remetem a múltiplas combinações moleculares, as quais põem em jogo não só o homem na mulher e a mulher no homem, mas a relação de cada um no outro com o animal, com a planta etc.: mil pequenos sexos" (idem, p. 90-91). Isto é, existe a segmentaridade molar, por exemplo na dupla homem-animal, mas esta dupla coexiste - não no mesmo plano - com segmentaridades moleculares; e algo se passa de uma para outra, como nas zonas de indiscernibilidade entre homens e animais, na relação entre homens e mulheres e suas aproximações e distanciamentos de animais, ou ainda nas transformações animais diante dessas duplas. "Do ponto de vista da micropolítica", eles continuam, "uma sociedade se define por suas linhas de fuga, que são moleculares. Sempre vaza ou foge alguma coisa, que escapa às organizações binárias, ao aparelho de ressonância, à máquina de sobrecodificação" (idem, p. 94). Todas as sociedades comportam segmentaridades molares e moleculares; as linhas de fuga, que se encontram no nível molecular, são aquilo que escapa e que a máquina de sobrecodificação, aquela que procura traduzir segmentos moleculares em molares, não consegue capturar. Riachos, vazamentos, ranhuras, rachaduras - o lugar da micropolítica. Falando em termos da relação com os animais, poderíamos dizer que o dualismo homem/animal é um segmento molar e que há todo um tipo de política envolvido nele, como a dos zoológicos, a das fábricas de produção animal e mesmo a da escravidão humana baseada em uma indistinção entre certos humanos e animais; no nível molecular, das linhas de fuga, há as saídas animais, humano-animais, animais-humanas, alianças multiespecíficas ou contra a natureza, e elas dizem respeito à micropolítica.

A política animal, estando ligada à ideia de saída, portanto, caracterizar-seia como uma micropolítica que corre nos interstícios da política molar ou institucional. Ela é, assim, uma política intensiva, e nesse sentido parece se aproximar da bruxaria evocada por Stengers, dispositivo capaz de escapar às

${ }^{69} \mathrm{Cf}$. primeiro capítulo, nota 8 . 
alternativas infernais capitalistas recolocando seus termos na política (agora uma cosmopolítica), na medida em que "faz escapar a representação social e opera uma desterritorialização do mundo que é ela mesma política" (Deleuze e Guattari, 1975, p. 85). A literatura tem aqui um papel de destaque, na medida em que o que está em jogo na escrita, para Deleuze e Guattari, é "transcrever agenciamentos; desmontar os agenciamentos" (idem, p. 86), que formam, segundo eles, um só movimento. Nos termos de Stengers, poder-se-ia dizer que tal transcrição e desmontagem são modos de "tornar-se capaz". Nas palavras de Pedro Vermelho, essa operação torna-se terrivelmente concreta:

Pela primeira vez na vida estava sem saída; ao menos em linha reta ela não existia; em linha reta diante de mim estava o caixote, cada tábua finamente ajustada à outra. É verdade que por entre as tábuas havia uma fresta que ia de lado a lado e, quando a descobri, saudei-a com o uivo bem-aventurado do animal irracional, mas nem de longe essa fresta bastava para deixar o rabo passar e mesmo com toda a força de um macaco ela podia ser alargada (Kafka, 1994, p. 60).

Essa saída que Pedro Vermelho percebe não existir é a saída molar: "em linha reta ela não existia"; o que ele precisa fazer então é sair intensivamente, tornar-se capaz, e mudar a situação por meio desse movimento. Mas por que Pedro estava sem saída? No conto, ele já se encontra, no momento em que enuncia essas palavras, diante de um auditório acadêmico, com o objetivo de relatar o modo pelo qual havia deixado de ser macaco para tornar-se homem - sua saída. Para tanto, precisa também narrar a seus ouvintes o que precipitou a necessidade de se transformar, o que faz seu relato recuar até a infância. Ele conta que nasceu na Costa do Ouro, região da África ocidental, atualmente parte de Gana, que começou a ser colonizada pelos europeus ainda no século XV e cuja história envolve a importação de escravos para trabalhar nas minas auríferas que deram nome ao lugar - pelo menos 10 mil foram levados para lá durante a primeira metade do século XVI (cf. Ferreira, 2010) - além, mais tarde, do envio forçado de pessoas para as Américas: “entre 1662 e 1700, as exportações britânicas de escravos [...] chegariam a 55.288 cativos e os holandeses embarcariam 9.263 escravos para as Américas" (Ferreira, 2010, p. 485).

Pedro Vermelho também é alguém que, durante o domínio do Império Britânico da área (1867-1957), fora capturado e transportado contra a sua vontade. Sua história pertence àquela da colonização e do capitalismo, que incluía o comércio de animais selvagens com o objetivo de um fornecimento sem fim de 
exemplares a zoológicos, circos e instalações de pesquisa, conforme já discutido em nosso segundo capítulo. A infeliz cena de sua captura, ainda criança, parece mesmo vinda de um dos relatos de caçadores que trabalhavam enviando animais da colônia para a metrópole, tanto mais porque o ex-macaco revela ter sido vítima de uma "expedição de caça" daquela mesma "firma Hagenbeck" fundada por Carl Hagenbeck, mercador e empresário célebre por revolucionar a forma dos zoológicos e promover exibições de povos humanos:

ao anoitecer, eu, no meio de um bando, fui beber água. Atiraram; fui o único atingido; levei dois tiros. Um na maçã do rosto: esse foi leve, mas deixou uma cicatriz vermelha de pelos raspados, que me valeu o apelido repelente de Pedro Vermelho (Kafka, 1994, p. 58).

A mesma firma é ainda mencionada algumas vezes durante o relatório; quando voltou a si, depois dos tiros, Pedro Vermelho viu-se preso em um caixote no qual três paredes haviam sido pregadas, dentro do navio a vapor da empresa: "O conjunto era baixo demais para que eu me levantasse e estreito demais para que eu me sentasse. Por isso fiquei agachado, com os joelhos dobrados, que tremiam sem parar" (idem, p. 59). O ainda macaco encontrava-se então no que Deleuze e Guattari chamam de o domínio do molar: "na firma Hagenbeck o lugar dos macacos é de encontro à parede do caixote - pois bem, foi por isso que deixei de ser macaco" (idem, p. 61). Se seguirmos nossos dois filósofos em sua recusa de enxergar em Kafka o uso de metáforas ou de representações, não podemos afirmar que a firma Hagenbeck representa o império colonizador no qual a situação dos macacos, "de encontro à parede dos caixotes", viria a figurar o lugar dos animais neste mundo; mas tampouco é preciso apelar a tais imagens, pois a firma é o império, é efetivamente um de seus tentáculos, aquele que se apropria dos animais exóticos pela caça, zoológico, aclimatação e domesticação, como observavam Baratay e Hardouin-Fugier. E, neste braço do império, o lugar dos macacos é quase sempre contra a jaula, seja nos navios a vapor ou nos zoológicos, entre a natureza e a cultura, em zonas de indistinção. É, portanto, diante desta situação que Pedro Vermelho procura, não a liberdade - algo que, como ele diz, "é um grande sentimento por todos os lados" (idem, p. 61), que talvez tenha conhecido em sua época de macaco mas que nem então exigia -, mas uma saída. Ele sabia que, dentro do caixote, dentro do navio, no meio do mar e a caminho da civilização, não tinha como escapar extensivamente, ou seja, para "fora do mundo": isso significaria ser novamente apanhado, talvez surrado, encontrar, 
quem sabe, animais peçonhentos que o matassem ou, caso nada disso acontecesse, o afogamento certo no oceano - um afogamento que se pareceria com aquele de Nikkie, o chimpanzé mais poderoso da Holanda, que justamente procurou escapar para fora. Pedro Vermelho pondera: "Se eu fosse um adepto da já referida liberdade, teria com certeza preferido o oceano a essa saída que se mostrava no turvo olhar daqueles homens" (idem, p. 63). Talvez Nikkie, do alto de seus poderes, tenha preferido a liberdade.

A saída de Pedro Vermelho precisou então ser intensiva: como uma infiltração que produz ranhuras em um cano antes de ele vazar, ele tomou a decisão de criar linhas possíveis pelas quais seguir: resolveu tornar-se humano. De início ele o conseguiu extensivamente, pela imitação - o macaco imitava os homens do navio bebendo e fumando, os macaqueava -, mas essa imitação foi apenas a estratégia encontrada por ele para efetuar sua fuga intensiva, qual seja, "produzir um contínuo de intensidades em uma evolução a-paralela e não simétrica na qual o homem não devém menos macaco que o macaco devém homem" (Deleuze e Guattari, 1975, p. 25). Pedro Vermelho, ao devir-homem - o que a princípio, em termos deleuzo-guattarianos, poderia parecer contraditório na medida em que o devir é sempre menor e o "homem" é o padrão, o maior -, força em troca os homens a um devir-macaco, um devir-animal. Não é à toa, explicam os autores, que o ex-macaco conta, sobre um de seus primeiros professores, que ele "quase se tornou ele próprio símio, teve de renunciar a lecionar e precisou ser internado num sanatório" (Kafka, 1994, p. 66):

Com efeito o animal capturado pelo homem se encontra desterritorializado pela força humana, todo o começo do Relatório insiste nesse ponto. Mas, por sua vez, a força animal desterritorializada precipita e torna mais intensa a desterritorialização da força humana desterritorializante (se se pode dizer isso) (Deleuze e Guattari, 1975, p. 25).

Em outra passagem, esse duplo devir fica ainda mais claro: Pedro Vermelho, ao falar sobre sua vida de artista, conta que seu "empresário está sentado na antessala; se toco a campainha ele vem" (Kafka, 1994, p. 67). Em uma inversão do que reza o behaviorismo de Pavlov, é o humano que reage ao animal pelo toque de uma campainha; o devir-humano do macaco arrasta consigo o homem em um devir-macaco, em um devir-animal. No começo de sua narrativa, Pedro Vermelho, em uma provocação darwinista, adverte os ouvintes: "Falando francamente, sua origem de macaco, meus senhores, até onde tenham atrás de si 
algo dessa natureza, não pode estar tão distante dos senhores como a minha está distante de mim" (idem, p. 58). O ex-macaco, assim, desafia a crença em uma história arborescente da evolução, que situa os animais antes do homem e a natureza fora da cultura; ao resistir a se fixar no início da humanidade, a ser seu antepassado, ele se constitui como um outro.

Pedro Vermelho faz, ainda, no começo do relato, uma descrição a respeito de sua vida símia e livre que lembra aquelas de Sokolowsky sobre a psiquê dos gorilas confinados que se apegavam à lembrança do sentimento de liberdade e por isso pereciam, sendo posteriormente encontrados imóveis em suas jaulas com os rostos virados para baixo. Seu feito, sua saída, a possibilidade de sobrevivência, tornar-se homem, diz Pedro Vermelho, "teria sido impossível se eu tivesse querido me apegar com teimosia à minha origem e às lembranças de juventude" (idem, p. 57); antes desta decisão, entretanto, sobre seus primeiros dias no navio à vapor Hagenbeck, ele comenta que "a princípio eu provavelmente não queria ver ninguém e desejava estar sempre no escuro" (idem, p. 59). Mas, diferentemente dos tristes filósofos de Sokolowsky, sem saída e por isso mortos poucos dias depois de terem chegado ao zoológico, Pedro Vermelho encontrou uma saída no e pelo conto kafkiano. Fora do conto, sua história ressoa a da vida de Consul, um chimpanzé que viveu no zoológico de Belle Vue, em Manchester, no final do século XIX, e cuja biografia Baratay escreveu.

Consul, que recebeu seu nome em homenagem ao cônsul britânico de Serra Leoa, nasceu não muito longe de Pedro Vermelho e, como tantos outros animais na mesma situação, ao ser capturado, teve sua mãe assassinada, após o que passou a viver entre serviçais indígenas em uma casa de donos europeus, onde chamava a atenção por participar de jogos que envolviam ferramentas, como pequenas lanças, até que finalmente, em 1893, foi vendido ao zoológico de Belle Vue. Ali, foi treinado para se apresentar ao público tomando chá, totalmente vestido e manejando xícaras, prato, garfo e colher com destreza; ao final do repasto, devia recolher os utensílios, mostrando hábitos humanizados ou, como observa Baratay, ocidentalizados. O que tornou o chimpanzé famoso, observa o autor, foi sua "recusa de uma simples vida de animal de zoológico e sua insistência em se inserir no mundo humano" (Baratay, 2017, p. 1678):

Desde a sua chegada, Consul devia se exibir três vezes por dia em público, às $9 \mathrm{~h}$, às $12 \mathrm{~h}$ e às $17 \mathrm{~h}$ para o chá. Moldado por Webb [seu treinador], ele aprendeu pouco 
a pouco. - Compreender o sinal. Abrir as portas do bufê (instalado para que se acreditasse ser um apartamento genuíno). Tirar toalha, guardanapo, talheres. Pousá-los em ordem sobre a mesa [...] Primeiramente a toalha. Faca sempre de um lado, garfo do outro. - Sentado, ele mostrava seus hábitos: alimentava-se exclusivamente com colher ou garfo, limpava os dedos sujos, abria a garrafa de limonada com os dentes, enchia o copo - levantava a tampa da chaleira para verificar o calor e a quantidade... (idem, p. 1741-1754).

Consul mostrava assim, ao público, a imagem de um verdadeiro elo perdido, um prodígio darwinista. Mas a repetição diária das mesmas tarefas o entediava e ele “desenvolveu uma 'aversão' pelo entorno e uma verdadeira obsessão: sair [sortir]" (idem, p. 1780). Tendo aprendido a destrancar o cadeado da jaula onde ficava preso quando não estava se apresentando, o chimpanzé escapava, não para a cidade, mas para passear pelo prédio no qual vivia; fez isso tantas vezes que o cadeado acabou sendo trocado, o que impossibilitou suas pequenas fugas. Mas Consul não desistiu: cada vez mais destro em suas apresentações, tornando-se assim uma verdadeira estrela do zoológico, ele ganhava, por isso, como uma espécie de recompensa, a possibilidade de passear, de estar fora da jaula cada vez por mais tempo. Começou a ser levado pela mão para observar os outros animais enjaulados e jamais se assustava ou agia inesperadamente; pelo contrário, tendo compreendido que tipo de comportamento lhe permitia estar fora, ele o cultivava:

Experimentava modos humanos nessas ocasiões; começava pela máquina de chocolate na frente de sua jaula, cujo manuseio ele deve ter espiado; prosseguia até a panificação, abria e fechava as gavetas, monitorava as operações, aprendeu sozinho a equilibrar a balança com os pesos; alhures, examinava atentamente e manipulava ferramentas, compreendia frequentemente seus fins; molhava os cantos do piso ainda secos com um cano, pintava o pedaço do muro ainda sujo com o pincel, levantava as tampas com o cinzel do carpinteiro, encontrava mesmo uma 'fonte de prazer' em abrir caixas cuidadosamente pregadas que preparavam para ele. Consul imitava, não macaqueando, mas observando, compreendia, aprendia [...] (idem, p. 1818).

Assim como Pedro Vermelho, Consul não macaqueava, mas observava e imitava com o objetivo de sair, sair da jaula, fazer o que fosse preciso para passar mais tempo fora. À certa altura, conforme conta Baratay, ele começou a frequentar o bar à noite, onde bebia e fumava com os outros frequentadores, apontando para suas garrafas favoritas. Como aconteceu com Pedro, o consumo "civilizado" de álcool e tabaco também foi uma porta de entrada para o mundo humano (de saída do mundo dos animais de zoológico). Em 1894, entretanto e infelizmente, o chimpanzé caiu doente, uma enfermidade de causa desconhecida - que o historiador aventa ter sido contraída pelas centenas de apertos de mão que Consul 
diligentemente dava em seres humanos diariamente, mais um dos requisitos para poder estar fora de sua jaula. De suas responsabilidades, o animal foi aliviado apenas por um breve período, no qual fez uma viagem ao campo, onde teve a oportunidade de correr pelo gramado. Mas afinal isso não foi suficiente. Consul

Sofria de dores crescentes, não retinha mais os alimentos, tornou-se em alguns dias "tão frágil que mal podia se mover." Para reduzir uma agonia "muito penosa de suportar" por seus humanos, ele se viu eutanasiado no dia 24 de novembro no fim do meio-dia com um lenço embebido em clorofórmio que o fez adormecer e em seguida parar de respirar. "Ele soltou uma exclamação, moveu-se como se tentasse se levantar, mas seus braços estavam muito frágeis para isso, e ele se rendeu docemente a seu último suspiro" (idem, p. 1908).

Consul, talvez o primeiro chimpanzé a ter encontrado uma saída ao mundo dos zoológicos, por meio de um esforço monumental no sentido de aprender como era preciso agir para ser aceito entre os homens, pereceu depois de menos de dois anos de sucesso. Depois de sua morte, seus feitos eram tão bem vistos e seu caso considerado como tão bem sucedido que houve quem lamentasse pelos chimpanzés selvagens "que não tiveram 'jamais as vantagens da sociedade europeia', que permaneciam 'subdesenvolvidos e perdidos para o mundo"' (idem, p. 1918). Depois dele, houve muitos outros chimpanzés com o mesmo nome, mas nenhum alcançou seu nível de humanização; Baratay conclui afirmando que

Consul tornou-se assim o modelo dos chimpanzés humanizados, numerosos até o meio do século, cujo estatuto ambíguo fez Kafka se interrogar em seu Relatório a uma academia (1917), pronunciado por um macaco antropomorfizado, um texto frequentemente analisado como uma metáfora da condição humana, na realidade uma denúncia dessa chimpanzidade (idem, p. 1930).

A saída de Pedro Vermelho, portanto, já havia sido concretamente encontrada por Consul. Nos dois casos, nunca se tratou de uma questão de imitação - assimilação, domesticação, aclimatação. Pedro Vermelho, sobre uma “pequena chimpanzé semi-amestrada" (Kafka, 1994, p. 67) que lhe oferecem e com quem ele passa as noites, diz que não suporta estar em sua presença durante o dia pois "ela tem no olhar a loucura do perturbado animal amestrado" (idem). Consul tampouco havia enlouquecido; pelo contrário, navegando pelo mundo que lhe fora dado habitar, ele encontrou suas linhas de fuga e saídas. 


\subsection{2.}

\section{Literatura e povo}

No primeiro capítulo levantamos a hipótese de a "saída" ser uma categoria da política animal ou da política do devir-animal. A vida de Consul e o conto de Kafka dão testemunho disso - da mudança intensiva operada por um animal, capaz de fazer uma situação escapar, fugir, de alterar o mundo sem sair dele, escavando, infiltrando-se nele de modo a que surjam novas ranhuras pelas quais se mover. Esse também é um modo, talvez eminentemente animal, de fazer política micropolítica, cosmopolítica.

E enquanto Consul viveu em um zoológico, sua história tendo sido mantida em diários e relatórios por mais de cem anos até que Baratay a tenha recolhido e enunciado em uma biografia, Pedro Vermelho habita o mundo desde 1917 pela pena de Kafka. Kafka fez Pedro Vermelho falar, em uma espécie de aliança multiespecífica e multigênero: de uma cambalhota de macaco até páginas compostas por linguagem articulada sob um gênero do discurso chamado literatura. Se consideramos as ideias de Bateson discutidas no segundo capítulo a respeito da brincadeira, com suas características de mapa e território e de fazer algo querendo significar outra coisa, aquilo que o autor considera um tipo de ficção e a possibilidade da linguagem humana, então, como diz Massumi:

A lógica corporificada pré-humana e pré-verbal da brincadeira animal já é essencialmente como a linguagem. Ela é efetiva e ativamente linguística avant la lettre, como humanos dizem em francês. Por que então o contrário não deveria ser o caso? Que a linguagem humana seja essencialmente animal, do ponto de vista das capacidades lúdicas que carrega, tão intimamente ligadas a seus poderes metalinguísticos? Pense no humor. Por que não considerar a linguagem humana uma retomada da brincadeira animal, elevada a um poder superior [to a higher power]? Ou dizer que é de fato na linguagem que o humano alcança seu nível mais alto de animalidade? Deleuze e Guattari insistem que é na escrita que o humano "devém-animal" mais intensamente, isto é, entra mais intensamente em uma zona de indiscernibilidade com sua própria animalidade (Massumi, 2015, p. 8).

A literatura, segundo Massumi, seria expressão da animalidade humana. Mas ela talvez atinja seu máximo de intensidade na relação com os animais pela ideia deleuzo-guattariana de "literatura menor", uma literatura que possui três características: faz uma minoria em uma língua maior por meio de sua desterritorialização; é sempre política, mesmo em questões individuais; e, finalmente, diz respeito ao povo e se encontra "positivamente carregada desse papel e dessa função de enunciação coletiva e mesmo revolucionária: é a literatura 
que produz uma solidariedade ativa" (Deleuze e Guattari, 1975, p. 31). A literatura menor pode, assim, desterritorializar a língua, fazendo-a vacilar em seus eixos e arrastando-a para continuidades outrora barradas, politizar questões consideradas econômicas, morais e privadas e invocar um povo - três movimentos que figuram uma saída para os animais: "pensamos e escrevemos para os animais. Tornamo-nos animal, para que o animal também se torne outra coisa" (Deleuze e Guattari, 2009, p. 142).

Em Crítica e Clínica, Deleuze asseverou que fazer literatura não é "contar as próprias lembranças, suas viagens, seus amores e lutos, sonhos e fantasmas" (Deleuze, 1997, p. 12); a literatura está do "lado do informe, ou do inacabamento" (idem, p. 11) e é "um caso de devir" (idem). Escrever, ele diz, é entrar em uma zona de vizinhança, de indiscernibilidade, que é impessoal mas não generalista; trata-se sempre de um macaco, uma mulher etc., ou seja, de uma singularidade. Longe de ser a expressão de um sentimento privado que encontraria vazão no papel, isto é, um caso de doença ("Não se escreve com as próprias neuroses", idem, p. 13), para o filósofo a literatura é uma questão de saúde, de liberação das enfermidades: "Qual saúde bastaria para libertar a vida em toda parte onde esteja aprisionada pelo homem e no homem, pelos organismos e gêneros e no interior deles?" (idem, p. 14). Essa saúde, ele responde em seguida, diz respeito a "inventar um povo que falta" (idem): "Compete à função fabuladora inventar um povo. Não se escreve com as próprias lembranças, a menos que delas se faça a origem ou a destinação coletiva de um povo por vir ainda enterrado em suas traições e renegações" (idem). Para compreender como é possível criar ou invocar um povo - um povo que falta - por meio da escrita, é preciso delinear a relação entre enunciação e coletividade. Em Kafka, pour une littérature mineur, lê-se que “a enunciação literária mais individual é um caso particular de enunciação coletiva" (Deleuze e Guattari, 1975, p. 150). Isso não quer dizer, entretanto, que o sujeito que escreve seja o povo ele mesmo, ou que o povo seja o objeto da escrita: o escritor "atual e a comunidade virtual - todos os dois reais - são as peças de um agenciamento coletivo" (idem). Em Diálogos, esse nexo fica mais claro:

É sempre um agenciamento que produz os enunciados. Os enunciados não têm por causa um sujeito que agiria como sujeito da enunciação, tampouco não se referem a sujeitos como sujeitos de enunciado. O enunciado é o produto de um agenciamento, sempre coletivo, que põe em jogo, em nós e fora de nós, populações, multiplicidades, territórios, devires, afetos, acontecimentos. $\mathrm{O}$ nome próprio não designa um sujeito, mas alguma coisa que se passa ao menos entre dois 
termos que não são sujeitos, mas agentes, elementos. Os nomes próprios não são nomes de pessoa, mas de povos e de tribos, de faunas e de floras, de operações militares ou de tufões, de coletivos, de sociedades anônimas e de escritórios de produção (Deleuze e Parnet, 1998, p. 43).

Desse modo, o que o "escritor inventa" são "agenciamentos a partir de agenciamentos que o inventaram", fazendo "passar uma multiplicidade para a outra" (idem). O agenciamento, finalmente, é "cofuncionamento, é a 'simpatia', a simbiose" (idem). A simpatia nesse caso remete ao uso que faz dela o escritor D. H. Lawrence, que a opunha à identificação; é ela que permite equilibrar-se no "meio", evitando a identificação e o que Deleuze chama de "olhar do entendimento", o distanciamento do "olhar científico asseptizado" (idem, p. 44). A simpatia, por sua vez, seria "o esforço ou a penetração dos corpos":

Não, diz Lawrence, vocês não são o pequeno esquimó que passa, amarelo e gorduroso, vocês não têm que se tomar por ele. Mas talvez vocês tenham algo a ver com ele, vocês têm algo para agenciar com ele, um devir-esquimó que não consiste em se passar pelo esquimó, a imitar ou em se identificar, em assumir o esquimó, mas em agenciar alguma coisa entre ele e vocês - pois vocês só podem se tornar esquimó se o próprio esquimó se tornar outra coisa (idem).

Por meio da simpatia, assim, ao produzir agenciamentos, o escritor é capaz de apresentar "a literatura como a enunciação coletiva de um povo menor", "bastardo, inferior, dominado, sempre em devir, sempre inacabado" (Deleuze, 1997, p. 14). Esse povo menor ou povo que falta, é a "raça oprimida, bastarda, inferior, anárquica, nômade, irremediavelmente menor - aqueles que Kant excluía das vias da nova Crítica" (Deleuze e Guattari, 2009, p. 141). No último parágrafo de "O que é o ato de criação?", quando Deleuze se perguntava sobre a relação entre povo e obra de arte, é dito que "o povo falta e, ao mesmo tempo, não falta e que "não há obra de arte que não faça apelo a um povo que não existe ainda" (Deleuze, 2003a, p. 302). Tal relação, conclui o filósofo, é misteriosa - mas não a afirmação de que o povo falta e, ao mesmo tempo, não falta, como se pode ler em seu segundo volume sobre cinema, Image-Temps:

Essa constatação de um povo que falta não é uma renúncia ao cinema político, mas, ao contrário, a nova base sobre a qual ele se funda, então, no terceiro mundo e nas minorias. É preciso que a arte [...] participe dessa tarefa: não se dirigir a um povo suposto, já aqui, mas contribuir para a invenção de um povo. No momento em que o mestre, o colonizador, proclama: "nunca houve povo aqui", o povo que falta é um devir, ele se inventa, nas favelas e nos campos, ou bem nos guetos, nas novas condições de luta para as quais uma arte necessariamente política deve contribuir (Deleuze, 1985, p. 283). 
Isto é, o povo que falta, esse que é invocado e ao qual os artistas podem fazer apelo, pode ser compreendido desde uma questão de perspectiva: o povo que falta é o povo denegado pelo mestre, pelo colonizador, por aquilo que é maior e padrão. A cada vez que um ministro de Estado sugere que a Amazônia é apenas uma coleção de árvores ou um grupo de pessoas; que rios são barrados para a construção de hidrelétricas; que se conduz fraturamento hidráulico em um terreno; que uma floresta é derrubada para monocultura; que se declara guerra a uma espécie, seja ela de mosquitos ou gatos e em tantas outras ocasiões, é o povo todas aquelas multiplicidades que, humanas e também outras que humanas, fazem aí seus mundos - que falta. Falta e se inventa, falta e é chamado, falta e não falta. O povo que falta não é uma questão de messianismo - não se trata de um povo eleito ou emancipado, exclusivo ou universal ${ }^{70}$ - mas de devir:

O artista ou o filósofo são bem incapazes de criar um povo, só podem invocá-lo, com todas as suas forças. Um povo só pode ser criado em sofrimentos abomináveis, e tampouco pode cuidar de arte ou de filosofia. Mas os livros de filosofia e as obras de arte contêm também sua soma inimaginável de sofrimento que faz pressentir o advento de um povo (Deleuze e Guattari, 2009, p. 142).

Faltam e não faltam os povos dos animais de trabalho, dos confinados, caçados, cobaias, indesejáveis, não-amados, não-queridos, das pestes e pragas - todos aqueles que não se constituem como fins em si mesmos, que não têm dignidade mas apenas preço, como dizia Kant em sua Metafísica dos Costumes (cf. Kant, 2013). Quem faz apelo a eles?

$\mathrm{Na}$ literatura, o povo que falta muita vezes se exprime na forma de povos animais. Em entrevista a Antonio Negri, Deleuze disse que "o povo é sempre uma minoria criadora, e que permanece como tal, mesmo quando conquista uma maioria: as duas coisas podem coexistir pois não vivem no mesmo plano" (Deleuze, 2004, p. 231) - molaridade e molecularidade. Embora um povo possa requerer maioria para sua sobrevivência na forma da luta por direitos reconhecidos por um Estado, por exemplo, ele permanece sempre menor, pois sua potência jaz na invenção, na criação, em suas linhas de fuga; essas invenções podem ser traduzidas para o modelo, mas nunca deixam de continuar acontecendo

70 Sobre o "caso Heidegger", "um grande filósofo [que] se reterritorializ[ou] sobre o nazismo", Deleuze e Guattari explicam que ele "ele se enganou de povo, de terra, de sangue. Pois a raça invocada pela arte ou a filosofia não é a que se pretende pura" (Deleuze e Guattari, 2009, p. 141); na sequência do texto, fazem referência a Kant, que por sua vez invocou um povo "saído [...] de sua menoridade" (cf. Kant, 2005, p. 63), excluindo da comunidade esclarecida todos aqueles que não querem ou não podem sair dela. 
em segmentos moleculares. Os artistas, diz o filósofo, estão sempre invocando povos que faltam, fazendo apelo a eles, mas não os podem criar; só o povo pode criar a si mesmo. Entre povos e artistas, entretanto, há algo comum, a saber, a função fabuladora. Em Image-temps, Deleuze chega a afirmar que "aquilo que se opõe à ficção não é o real, não é a verdade, que é sempre aquela dos mestres ou dos colonizadores, e sim a função fabuladora dos pobres, na medida em que ela dá ao falso a potência que faz dele uma memória, uma lenda, um monstro" (Deleuze, 1985, p. 196). E, ainda, que "um ato de fabulação" pode não ser mais "um retorno ao mito, mas uma produção de enunciados coletivos capaz de elevar a miséria a uma estranha positividade, justamente a invenção de um povo" (idem, p. 289). O encontro entre povo e artistas não se dá através de mitos fundadores - que não são senão perigosas ficções nacionalistas, como mostra o modo pelo qual os nazistas se apropriaram do romantismo alemão. O povo menor fabula, e fabular significa criar memórias e monstros - alianças contra-natureza. Talvez seja possível aproximar essa função fabuladora da "potência desenfreada da aliança" (Deleuze e Guattari, 2005, p. 30) aludida no platô "Devir-intenso, devir-animal, devirimperceptível", encontrada em povos selvagens e camponeses e suas produções de "homens-leopardos, homens-jacarés", "homens-lobos, homens-bodes", alianças "superior[es] e exterior[es] à ordem da família" (idem), contra a Igreja, contra o Estado. Do lado dos artistas, não é possível esquecer a relação entre fábulas e animais, de Esopo a La Fontaine até Kafka. Em suma, fabular nunca parece dizer respeito a encontrar uma origem nacional ou uma raça pura, mas a estabelecer uma aliança com o fora, contra o mestre em suas formas institucionais do império colonizador, do Estado, da Igreja ou da família.

Falta o povo dos ex-macacos, o povo que encontra uma saída diante do caixote da firma Hagenbeck; ou o povo dos ratos, que Josefina faz surgir por seu canto em "Josefina, a cantora ou O povo dos camundongos", aquele povo de vida dura, "muito intranquila", que "cada dia traz surpresas, temores, esperanças e sustos" (Kafka, 2002, p. 42), povo "que de algum modo sempre salvou a si próprio, mesmo às custas de vítimas, diante das quais o pesquisador de história em geral negligenciamos totalmente a pesquisa histórica - fica gelado de pavor" (idem, p. 46). O narrador-multidão do conto, que gira em torno da excepcionalidade de uma rata-cantora, Josefina, em meio a uma sociedade 
abnegada e sem artistas, explica que ela não é uma salvadora: de modo muito menos teleológico e profundamente político, ela, com seu canto, invoca um povo:

Esse assobio, que se eleva onde o silêncio se impõe a todos os outros, chega ao indivíduo quase como uma mensagem do povo; seu assobio fino, em meio às decisões difíceis, é quase como a existência miserável de nosso povo em meio ao tumulto do mundo hostil (idem, p. 47).

Kafka invoca Josefina que faz apelo a um povo. Segundo Max Brod em sua biografia do escritor, a nomeação deste conto foi um dos últimos atos de sua vida e ele lhe teria passado um bilhete no qual se lia: "Ao conto é preciso dar um título novo: 'Josefina, a cantora ou O povo dos camundongos.' Um título com ou não é muito belo, mas talvez tenha um significado particular. Recorda um pouco o equilíbrio" (Kafka apud Brod, 1956, p. 231-232). Singularidade e coletividade. Deleuze dizia que Kafka apresentava a literatura "como a enunciação coletiva de um povo menor, de todos os povos menores que só encontram expressão no escritor e através dele" (Deleuze, 1994, p. 14). E, de fato, quem canta o povo dos ratos? Primeiramente é Josefina, que, vocalizando uma estranha música, um assobio modificado, torcido e tornado canto - "todos nós assobiamos, mas certamente ninguém cogita fazê-lo passar por arte" (Kafka, 2002, p. 38), lembra o narrador - emite "quase uma mensagem do povo", um povo certamente menor, subterrâneo e mesmo maldito. Josefina pôde transformar seu assobio em canto do povo através de Kafka, a quem, por meio de uma aliança contra a natureza, coube cantar os ratos; por sua vez, ela e os ratos, de volta, deram a ele uma voz, a escrita tornada guincho, a possibilidade da literatura: tornar-se, com os bichos e diante deles, escritor.

Em "The Author of The Acacia Seeds", a escritora Ursula K. Le Guin faz apelo ao povo das formigas; na primeira parte do conto, o autor de um artigo acadêmico publicado na "Revista de Terolinguística", publicação de literatura animal, procura decifrar mensagens deixadas por uma pequena formiga em sementes de acácia pouco antes de seu assassinato, provavelmente por uma formiga soldado. A tarefa é difícil, pois "nenhum dialeto conhecido de Formiga emprega pessoas verbais, além da terceira pessoa do singular e do plural e a primeira pessoa do plural", além de que, no texto em questão, "somente os radicais dos verbos são usados" (Le Guin, 2014, p. 8792-8742); isto é, a mesma frase pode significar "[eu] gast[arei] nessas sementes secas a doçura de [minha] alma" ou, diferentemente, "gast[e] nessas sementes secas a doçura de [sua] alma" 
(idem, p. 8792). Mais uma vez, o que está em jogo é uma singularidade, esta formiga que deixou uma mensagem, e uma coletividade - o povo das formigas, sua enunciação. Tal característica da língua Formiga torna o gênero da escrita nas sementes indiscernível entre "uma autobiografia ou um manifesto" (idem, p. 8742). Não indistintos, mas avizinhados, em comunicação, em devir; esse é o modo singular e impessoal pelo qual as formigas habitam ou expressam seu mundo:

A máquina literária substitui assim uma máquina revolucionária por vir, de modo algum por razões ideológicas, mas porque apenas ela está determinada a preencher as condições de uma enunciação coletiva que falta por todo o canto neste meio: a literatura é questão do povo (Deleuze e Guattari, 1975, p. 32).

A questão do povo das formigas e da singular formiga - uma formiga - que deixou uma autobiografia/manifesto para ser traduzida não é simples: a última das sementes, de número 31, condensa em si um enigma. Sua tradução informa todo o resto do conjunto e tem o poder de fazer o sentido das sementes se inverter. Ali se lê "Para cima com a rainha! [Up with the queen!]" (Le Guin, 2014, p. 8742). O autor-narrador explica que há quem entenda essa exortação como oriunda de uma fêmea trabalhadora e portanto estéril, que sonha em ser macho para poder voar com a rainha em núpcias para uma nova colônia. Mas há uma outra possibilidade, ele lembra, menos "etnocêntrica" (idem, p. 8756): costuma-se interpretar a exortação "para o alto!" de modo positivo porque em nosso mundo acostumamonos a relacionar a altura ou o céu com a bem-aventurança; as formigas, por sua vez, são criaturas subterrâneas. O alto para elas certamente é de onde vem a comida, mas pode significar principalmente o "sol escaldante; a noite congelante; nenhum abrigo nos amados túneis; exílio; morte" (idem). Esse caminho de compreensão encontraria uma solução de tradução mais apropriada para o entendimento humano em "Abaixo a rainha!", “a máxima blasfêmia concebível para uma formiga" (idem). O artigo conclui com a informação de que aquele formigueiro fora destruído em guerra com outro, algum tempo depois do assassinato por decapitação da autora das sementes de acácia. Uma traidora? Conspiradora? Anarquista? Poeta? Uma rebelde, como aquelas que resistem aos trabalhos forçados impostos por outras espécies?

O tradutor - ou tradutora, o conto não deixa claro - precisa entrar em um devir-formiga para compreender aquelas sementes. As mensagens deixadas obrigam quem quer que deseje entendê-las a se deixar arrastar até um contínuo 
animal-humano, a trocar algo com as formigas, penetrar seu mundo sob a condição de ser penetrado por ele. Em suma, a experimentar atravessamentos humanos-formigas e formigas-humanos. A autora das sementes de acácia se torna autora e rebelde, enquanto o acadêmico que a traduz se torna formiga experimentando túneis como amados, o alto como temível e rebelando-se diante das traduções tradicionais. O resultado é uma sociedade formiga literata, musical, com conspiradores, rebeldes e soldados, que mantém a ordem ao mesmo tempo em que a sociedade humana-ocidental se vê subitamente aparentada daquele mundo estratificado, no qual dissidentes podem enfrentar a morte pelas mãos/mandíbulas de soldados a serviço do Estado. O povo das formigas invocado, finalmente, é mais aquele da rebelde, a informante através de quem se as escuta, que o das instituições. Não há assobio, mas as sementes encontradas estavam dispostas como uma "partitura musical" - a pequena música das dissidentes, bastardas, capaz de, como o canto de Josefina, "ser uma mensagem do povo."

\subsection{3. \\ Devir-animal}

A busca de uma saída pode portanto ser considerada um procedimento da política animal. Como uma linha de fuga, a saída tem como condição o devir, ou, em outras palavras, para se encontrar uma saída é preciso entrar em devir. $\mathrm{Na}$ primeira série de paradoxos da Lógica do sentido, Deleuze apresenta o conceito de "puro devir" tomando, entre outros, o exemplo da menina protagonista de Alice no país das maravilhas, de Lewis Carroll, repetidamente tornando-se maior (do que era) e menor (do que será) ao mesmo tempo. Tal simultaneidade é possível porque se dá fora do regime do tempo concebido em termos de passado, presente e futuro. Alice não é maior e menor ao mesmo tempo, adverte o filósofo, ela se torna maior e menor ao mesmo tempo. Trata-se, justamente, de devir e não de ser. E o devir, esse acontecimento puro "que se furta ao presente" (Deleuze, 2003b, p. 1), despedaça, segundo Deleuze, o princípio de identidade segundo o qual um objeto é sempre idêntico a si mesmo. Enquanto A é sempre igual a A, A(lice) difere de A(lice) enquanto devém. "O bom senso é a afirmação de que, em todas as coisas, há um sentido determinado; mas o paradoxo é a afirmação dos dois sentidos ao mesmo tempo" (idem) e "O paradoxo é, em primeiro lugar, o que destrói o bom 
senso como sentido único, mas, em seguida, o que destrói o senso comum como designação de identidades fixas" (idem, p. 3).

Um dos trechos citados por Deleuze para ilustrar a "identidade infinita" que é o paradoxo mesmo do puro devir envolve uma espécie de confusão (ou confusão de espécie) experimentada por Alice quando, ao perseguir o coelho, no começo de sua aventura, cai em um buraco profundo: “Será que os gatos comem os morcegos?' é o mesmo que 'será que os morcegos comem os gatos?"' (idem). No texto de Lewis Carroll, no entanto, a confusão parece ainda maior:

Para baixo, para baixo, para baixo. Não havia nada mais a fazer, então Alice logo começou a falar de novo. "Dinah vai sentir muito a minha falta, eu acho!" (Dinah era a gata). "Espero que se lembrem de seu pires de leite na hora do chá. Dinah, minha querida! Queria que você estivesse aqui embaixo comigo! Não há ratos no ar, desconfio, mas você poderia pegar um morcego, que é muito semelhante a um rato, sabe. Mas será que gatos comem morcegos, eu me pergunto." E aqui Alice começou a ficar com muito sono, e continuou dizendo a si mesma, meio sonhando: 'Gatos comem morcegos? Gatos comem morcegos?" e, às vezes, "Morcegos comem gatos?", pois, percebam, como ela não conseguia responder à nenhuma das questões, não importava muito a ordem em que as punha. Ela sentiu que estava adormecendo e tinha começado a sonhar que estava andando de mãos dadas com Dinah, e lhe dizia de modo muito franco: "Agora, Dinah, diga-me a verdade: você já comeu um morcego?", quando, de repente, cataploft!, caiu em cima de um amontoado de gravetos e folhas secas e a queda tinha terminado (Carroll, 1998, p. $4-5)$.

Dinah, a gata, certamente gosta de caçar ratos - mas não há ratos no buraco. Há, por outro lado, morcegos, que são muito parecidos (very like) com ratos, Alice pensa. Então, se gatos comem ratos e ratos são muito parecidos com morcegos, será que gatos comem morcegos? Ou será que morcegos comem gatos? Para Deleuze, segundo o paradoxo do devir, como vimos, as duas perguntas tornam-se indistinguíveis, pois o devir "não se detém nunca, nos dois sentidos ao mesmo tempo, sempre furtando-se ao presente, fazendo coincidir não só passado e futuro, mais e menos" (Deleuze, 2003b, p. 1), mas também causa e consequência. O que se segue daí é a perda da identidade pessoal, que precisa de um ponto fixo, de "uma permanência" (idem, p. 3).

O devir, como vimos nessa breve análise, é "devir puro", "devir louco". Mas na obra subsequente de Deleuze o conceito retorna diferente, hifenizado: devir-animal, devir-mulher, devir-índio, devir-intenso, devir-imperceptível. Iremos nos deter na primeira dessas modalizações, o devir-animal..

$\mathrm{Na}$ verdade, talvez seja possível começar a pensar o devir-animal, antes sequer de sua primeira aparição - no livro sobre Kafka - a partir de um outro 
episódio do livro de Lewis Carroll. Da série de encontros em sua aventura em que as identidades fixas são colocadas em xeque, há um, que Deleuze não cita, em que tal confusão se exacerba. Passa-se que Alice resolve resgatar um bebê cuja mãe, a Duquesa, a tratava muito mal para o gosto da menina. Em dado momento, o bebê, que ela carrega em seus braços enquanto foge, no meio de um choro que the deforma o rostinho, fazendo com que seus olhos se tornem pequenos demais e que seu nariz possa ser descrito mais como um focinho, começa a virar um porco:

Não, não havia lágrimas. "Se você vai se tornar um porco, meu querido", disse Alice, seriamente, "Não terei mais nada a ver contigo. Veja bem!" A pobre coisinha soluçou de novo (ou grunhiu, era impossível distinguir), e eles seguiram por um tempo em silêncio (Carroll, 1998, p. 87).

Neste ponto, Alice tem no colo uma criatura que não é nem mais bebê-humano nem ainda porco ("era impossível distinguir"); nos dois parágrafos seguintes a transformação se completa e o bichinho vai-se embora trotando bosque adentro. Wonderland, o reino do acontecimento, não faz apenas com que Alice possa se tornar maior e menor ao mesmo tempo, perdendo sua identidade; também causa no bebê um devir-porco, que se consuma na transformação total do pequeno em leitão. Mas será que podemos já chamar esse virar-porco vislumbrado por Carroll de devir-animal no sentido deleuziano? E, se não, por quê?

Poder-se-ia, com razão, objetar que o que se passa com o bebê não é um devir, já que ele, ao fim do processo, é mesmo um porco e, em um devir, não se trata de se transmutar fisicamente noutra coisa; Deleuze, no livro Diálogos, chegou mesmo a afirmar que “A pergunta 'o que você devém?' é particularmente estúpida. Pois à medida que alguém se transforma, aquilo em que ele se transforma muda tanto quanto ele próprio" (Deleuze e Parnet, 1998, p. 10). Como observou Viveiros de Castro, "o verbo devir, neste sentido, não designa uma operação predicativa ou uma ação transitiva: estar implicado em um devir-onça não é a mesma coisa que virar uma onça. É o devir ele próprio que é felino, não seu 'objeto"" (Viveiros de Castro, 2007, p. 116). Seguindo esta última pista, por outro lado, não é possível negar que o bebê é atravessado, o tempo todo em que Alice está em sua presença, por afetos suínos - além de sua mãe o chamar de porco pelo menos uma vez, os verbos usados para suas ações até sua total transformação são, respectivamente, howl, snort e, finalmente, grunt. No livro sobre Kafka, Deleuze e Guattari explicaram que: 
Devir-animal é, precisamente, fazer o movimento, traçar a linha de fuga em toda a sua positividade, transpor um limiar, atingir um continuum de intensidades que só valem por elas mesmas, encontrar um mundo de intensidades puras onde todas as formas se desfazem, todas as significações também, significantes e significados, em benefício de uma matéria não formada, de fluxos desterritorializados, de signos assignificantes. Os animais de Kafka não remetem jamais a uma mitologia nem a arquétipos, correspondem somente a gradientes atravessados, a zonas de intensidade liberadas nas quais os conteúdos se libertam de suas formas não menos que as expressões do significante que as formalizava. Nada além de movimentos, de vibrações, de limiares em uma matéria deserta: os animais, ratos, cães, macacos, baratas se distinguem somente por tal ou tal limiar, por tais ou tais vibrações, por tal caminho subterrâneo no rizoma ou na toca. Pois os caminhos são intensidades subterrâneas. No devir-rato, é um silvo que arranca das palavras sua música e seu sentido. No devir-macaco, é uma tosse "que parece inquietante, mas não tem significação" (devir-macaco da tuberculose). No devir-inseto, é um piar doloroso que causa a voz e embaralha a ressonância das palavras. Gregor devém inseto, não somente para fugir de seu pai, mas antes para encontrar uma saída ali onde seu pai não a soube encontrar, para fugir do gerente, do comércio e dos burocratas, para atingir essa região na qual a voz não faz senão zumbir - "Você o ouviu falar? Era uma voz animal, declarou o gerente.” (Deleuze e Guattari, 1975, p. 24-25).

O devir-porco do bebê de Alice, a maneira como ele grunhe e torce o nariz, é justamente aquilo que, para ele, se constitui como a fuga da casa da duquesa malvada. Gregor Samsa tornara-se inseto para escapar de ser burocrata; do bebê sabemos pouco, talvez tenha se tornado porco para escapar aos maus-tratos. Talvez tenha se tornado porco para não chegar a ser capturado pelo mundo da nobreza ou mesmo para escapar de ser homem. O que sabemos de fato é que ele escapa para dentro do bosque tão logo Alice o tira do castelo.

Em uma conferência intitulada “Qu'est-ce qu'un devenir, pour Gilles Deleuze?”, de 1997, François Zourabichvili procura “expor”, ainda que sob a forma de um esboço, o conceito de devir. Devir, ele diz, é antes de mais nada mudar:

é não mais se comportar nem sentir as coisas da mesma maneira; não fazer mais as mesmas avaliações. (...) "devir" significa que os dados mais familiares da vida mudaram de sentido, ou que nós não mantemos mais as mesmas relações com os elementos habituais de nossa existência: o conjunto todo é reencenado de outra maneira (Zourabichvili, 1997, p. 2).

Para que essa mudança aconteça, como vimos no primeiro capítulo, é necessária "a intrusão de um fora" (idem), que deve ser um fora total, uma "outra coisa que si mesmo”, isto é, o não-humano. “... é preciso admitir que não encontramos em sentido forte senão o não-humano, o inumano" (idem, p. 3) - ainda que se trate de outro humano; se há um encontro entre dois humanos, o que se encontra no outro deve ser a sua não-humanidade. Um devir é, assim, uma relação entre termos 
radicalmente heterogêneos; é apesar disso, contra o que se poderia esperar, que algo se passa entre esses dois termos. Do encontro, duas experiências distintas se produzem, uma em A (para B), outra em B (para A).

Estou objetivamente em relação com o outro, tendo objetivamente captado algo dele (e ele de mim); há, então, um devir comum aos dois, unindo indiscutivelmente vivências divergentes. O que um experimenta é inseparável da relação com o outro, mas não se confunde em nada com o que o outro experimenta; os afetos, diferentes nos dois lados, não se produzem um sem o outro (idem, p. 4).

Para Zourabichvili, o devir será, assim, uma "identificação sem identidade, uma comunicação sem nada comum" (p. 5). Os dois termos que se encontram, irredutivelmente diferentes, entram em uma relação que se bifurca em duas, uma para cada um em direção ao outro, e essa relação "modifica a economia interna de cada um dos termos. (...) A relação se estabelece menos entre um termo e outro que entre cada termo e aquilo que ele capta do outro" (idem). A palavra que ele usa é "ressonância" (idem, p. 9).

Quer dizer, de acordo com Zourabichvili, para um homem em devir-rato, o rato, pura heterogeneidade a princípio incomunicável, afeta o homem, fazendo com que algo se dê: o próprio devir. A "economia interna" modifica-se: "Na relação com um animal, afirmamos necessariamente um 'mundo' que não é o nosso, possibilidades de vida e perspectivas sobre o mundo que nos são estrangeiras e que não pressentimos sem sentir medo" (idem, p. 4). A partir dessa explicação, pode-se entender como é possível que tanto o rato quanto o devir sejam reais sem que o homem no devir se transforme em um rato de verdade. A palavra-chave aqui é o afeto. Mais tarde, na mesma conferência, Zourabichvili resume: não se trata de sentir como o animal, mas de "sentir como sentimos que ele sente, senti-lo sentir em nós" (idem, p. 9). Não se trata, portanto, de uma representação do animal ou do sentimento do animal, mas do animal como afeto, do animal como "causa em nós de uma alteração afetiva ${ }^{71 " ~(i d e m) . ~ U m ~ d e v i r-~}$ animal não é jamais uma metáfora:

Não há mais sentido próprio nem sentido figurado, mas uma distribuição de estados no leque da palavra. (...) Não há mais nem homem nem animal, pois cada

71 "Pode ser que o animal sinta de uma maneira inimaginável (ao ponto que a questão da diferença entre uma sensação animal e uma sensação humana não tem nem sentido, pois uma sensibilidade só é sensível no contato efetivo de uma outra), a sensibilidade que se torna a nossa com o seu contato e que nós não podemos senão lhe atribuir não é menos objetivamente uma outra maneira de sentir pela qual nós devimos-animal" (Zourabichvili, 1997, p. 9). 
um desterritorializa o outro, numa conjunção de fluxos, em um continuum reversível de intensidades (Deleuze e Guattari, 1975, p. 40).

É um mapa de intensidades. É um conjunto de estados, todos distintos uns dos outros, enxertados no homem enquanto ele procura uma saída. É uma linha de fuga criadora que não quer dizer outra coisa além dela mesma (idem, p. 65).

Afirmar que o devir-animal não é uma metáfora poderia parecer indicar que existe um sentido próprio dos termos no devir; não é o caso, no entanto, pois “já não há homem nem animal." Zourabichvili explica, a esse respeito, que

[Deleuze] contesta a dualidade sobre a qual se construiu, desde sempre, o conceito de metáfora: a utilização de um termo em seu domínio próprio e a utilização desse mesmo termo fora de seu domínio. Ele critica essa dualidade por subordinar o pensamento à ordem da mímesis, como se pode ver em Aristóteles: o conceito de metáfora supõe a classificação natural, e o ato humano de classificar aparece, na melhor das hipóteses, como uma duplicação. Ora, a experiência não justifica absolutamente tal divisão natural das significações (Zourabichvili, 2005, p. 1314).

Para ele, a relação entre dois termos deve ser pensada "na ausência de qualquer atribuição prévia e, consequentemente, para além da divisão entre a utilização própria das palavras e a sua utilização figurada" (idem, p. 1315). Dito de outro modo, já não possuindo um sentido próprio, os termos em relação adquirem sentido pela própria relação. Como Deleuze destacou diversas vezes, trata-se da conjunção E no lugar do É. Em uma proposição tal como a de que Zourabichvili faz uso, "o cérebro é uma erva", temos então dois termos, cérebro e erva; e, antes de querer dizer que o cérebro, este termo portador de um sentido próprio e prévio, é como uma erva, palavra que também possui um sentido anterior e próprio, mas que aqui passaria a assumir um sentido figurado, causando no termo próprio cérebro a invasão desse sentido figurado, erva (não poderia se tratar, segundo esse modo de pensamento, de uma erva em sentido próprio, é claro), o que temos são cérebro e erva em uma relação que cria o seu sentido. "Não existe sentido ou experiência a não ser na base de uma relação" (idem, p. 1316). No que diz respeito ao devir, isso fica ainda mais claro, já que ambos os termos encontram-se desterritorializados ${ }^{72}$; o privilégio da relação sobre o sentido

72 A respeito das novelas animalistas de Kafka, Deleuze e Guattari dizem: “1º) Não há mais lugar para distinguir o caso no qual o animal é considerado por si mesmo e o caso no qual há metamorfose; tudo no animal é metamorfose, e a metamorfose está em um mesmo circuito devirhomem do animal e devir-animal do homem; $2^{\circ}$ ) a metamorfose é como a conjunção de duas desterritorializações, aquela que o homem impõe ao animal forçando-o a fugir ou o escravizando, mas também aquela que o animal propõe ao homem, indicando-lhe saídas ou meios de fuga nos quais o homem jamais teria pensado sozinho (a fuga esquizo); cada uma das duas desterritorializações é imanente à outra, precipita a outra, e a faz atravessar um limiar; $3^{\circ}$ ) o que 
próprio é a afirmação da conjunção $e$ sobre o verbo ser, ou seja, no limite, a "extinção do ser em prol da relação (ou, ainda, do devir)" (idem). Isto é, a objeção à metáfora é uma objeção ao ser como próprio, uma afirmação do devir como relação. Em um devir-animal nem o humano nem o animal estão dados de antemão, mas o sentido surge pela relação. Agora podemos compreender a insistência de Deleuze e Guattari em que um devir não pode ser uma imitação nem um jogo de palavras, mas sim uma realidade: “A metamorfose é o contrário da metáfora" (Deleuze e Guattari, 1975, p. 40).

Em um artigo chamado "Le devenir-animal et la question du politique chez Gilles Deleuze", a filósofa Elaine Martin-Haag explica que:

Os devires-animais só valem na medida em que fazem escapar da instituição familiar como do aparelho de Estado; na medida em que nos levam a um devirmatilha ou devir múltiplo que "metamorfoseia", no sentido de que a metamorfose é uma ultrapassagem de formas e produz um a-formal (Martin-Haag, 2008, p. 12).

Há, no devir-animal, portanto, um tipo de política. Uma política que dá ao humano uma saída de instituições tais como família e Estado (lembremos de Gregor Samsa tornando-se inseto para não virar burocrata). Trata-se do encontro de duas heterogeneidades criando uma linha de fuga, do sujeito para o agenciamento coletivo de enunciação. No devir-animal encontra-se a possibilidade mesma do processo de individuação sem sujeito, isto é, de uma hecceidade. O encontro com o animal - que é sempre um bando do qual se escolhe aquele que vive à borda, o anômalo (sem nomos, e não anormal, que supõe uma normalidade), quer dizer, de tipos como Josefina, a cantora do povo dos camundongos - possibilita a relação de aliança em vez da de filiação, uma "aliança demoníaca”, que desterritorializa o homem (“já não há homem nem animal").

Na seção "Lembranças de um feiticeiro", do platô "Devir-intenso, deviranimal, devir-imperceptível”, de Mil Platôs, Deleuze e Guattari explicitam o que

conta então não é de jeito nenhum a lentidão relativa do devir-animal; pois, por mais lento que seja e quanto mais lento for, ele constitui nada menos que uma desterritorialização absoluta do homem, por oposição às desterritorializações relativas que o homem opera sobre si mesmo ao se deslocar, viajando; o devir-animal é uma viagem imóvel e no mesmo lugar, que não se pode viver ou compreender senão em intensidade (atravessar os limiares de intensidade). $\mathrm{O}$ devir-animal não tem nada de metafórico. Nenhum simbolismo, nenhuma alegoria. Também não é o resultado de uma culpa ou de uma maldição, o efeito de uma culpabilidade. Como diz Mélville a propósito do devir-baleia do capitão Achab, é um 'panorama', não um 'evangelho.' [...] o devir-animal não deixa nada subsistir da dualidade de um sujeito de enunciação e um sujeito do enunciado, mas constitui um único e mesmo processo, um único e mesmo processo que substitui a subjetividade" (Deleuze e Guattari, 1975, p. 64-65). 
seria essa política do devir-animal. Colocando-se do lado dos "feiticeiros", aqueles "traidores" que se aliam com os anômalos e celebram "núpcias contra natureza" ("O feiticeiro está numa relação de aliança com o demônio como potência do anômalo", Deleuze e Guattari, 2005, p. 28), os autores descrevem o devir-animal como um tipo de política capaz de criar linhas de fuga para fora de instituições universalizantes tais como a família, o Estado e a Igreja:

Citemos desordenadamente, não como misturas a serem feitas, mas antes como diferentes casos a serem estudados: os devires-animais na máquina de guerra, homens-feras de todas as espécies, mas justamente a máquina de guerra vem de fora, extrínseca ao Estado que trata o guerreiro como potência anômala; os deviresanimais nas sociedades de crime, homens-leopardos, homens-jacarés, quando o Estado proíbe as guerras locais e tribais; os devires-animais nos grupos de sublevação, quando a Igreja e o Estado encontram-se diante de movimentos camponeses com componente feiticeiro, e que irão reprimir, instaurando todo um sistema de tribunal e de direito próprio a denunciar os pactos com o demônio; os devires-animais nos grupos de ascese, o anacoreta roedor, ou besta fera, mas a máquina de ascese está em posição anômala, em linha de fuga, fora da Igreja, e contesta sua pretensão de erigir-se como instituição imperial; os devires-animais nas sociedades de iniciação sexual do tipo "deflorador sagrado", homens-lobos, homens-bodes, etc., que se valem de uma Aliança superior e exterior à ordem das famílias, enquanto que as famílias terão que conquistar contra eles o direito de ajustar suas próprias alianças, de determiná-las segundo relações de dependência complementar e de domesticar essa potência desenfreada da aliança (Deleuze e Guattari, 2005, p. 30).

A menção aos feiticeiros e aos pactos com o demônio não é em vão; os próprios tribunais de inquisição são uma maneira de as instituições neutralizarem esse tipo de aliança com o não-humano. Há uma "potência desenfreada da aliança" que precisa ser "domesticada" pela família, caso esta queira persistir. O devir-animal permite ao homem "uma saída", "uma linha de fuga viva" (idem, 1975, p. 64). Mas há também, no devir-animal, advertem os autores, uma ambiguidade que é enunciada, no livro sobre Kafka, como advinda do fechamento e da forma do animal ele mesmo e, em Mil Platôs, como o perigo da captura pelas instituições ou como uma reterritorialização simbólica dos animais. Do primeiro texto:

Não será, antes, porque os devires animais não conseguem cumprir o seu princípio, guardando sempre uma ambiguidade que constitui sua insuficiência e os condena ao fracasso? Os animais não são ainda muito fechados, muito significantes, muito territorializados? Não é o conjunto do devir-animal que oscila entre uma saída esquizo e um impasse edipiano? (idem, p. 27-28).

Ou seja, é possível que os animais não sejam assim tão heterogêneos, que sua não-humanidade contenha ainda alguma humanidade. Nesse caso, corre-se o 
risco de não se conseguir seguir a saída que surge no devir-animal até o fim. No capítulo sobre devir-animal, esse perigo é descrito assim:

Então, evidentemente, a política dos devires-animais permanece extremamente ambígua, pois as sociedades, mesmo primitivas, não deixarão de apropriar-se desses devires para caçá-los e reduzi-los a relações de correspondência totêmica ou simbólica. Os Estados não deixarão de apropriar-se da máquina de guerra, sob forma de exércitos nacionais que limitam estritamente os devires do guerreiro. A Igreja não deixará de queimar os feiticeiros, ou então de reintegrar os anacoretas na imagem abrandada de uma série de santos que não têm mais com o animal senão uma relação estranhamente familiar, doméstica. As Famílias não deixarão de conjurar o Aliado demoníaco que as corrói, para ajustar as alianças convenientes entre si. Ver-se-á os feiticeiros servirem aos chefes, colocarem-se a serviço do despotismo, fazerem uma contra-feitiçaria de exorcismo, passar para o lado da família e da dependência. Mas será também a morte do feiticeiro, como aquela do devir. Ver-se-á o devir parir apenas um grande cachorro doméstico, como na danação de Miller ("era melhor simular, fazer-se de animal, de cachorro, por exemplo, agarrar o osso que jogariam para mim de tempos em tempos") ou a de Fitzgerald ("tentarei ser um animal tão correto quanto possível, e se você me jogar um osso com bastante carne por cima, talvez serei até capaz de lamber sua mão"). Inverter a fórmula de Fausto: então era isso, a forma do Estudante ambulante? um reles cachorrinho! (idem, 2005, p. 30-32).

O problema da política do/no devir-animal repousaria, então, na sua reterritorialização possível: "o devir parir apenas um grande cachorro doméstico". O risco todo é que Fausto, seguido até sua casa por um cão negro, terminasse, não firmando um pacto com o demônio que esse cachorro revelasse ser, mas afagando os pelos macios de um dócil poodle. Para Deleuze e Guattari, o animal ainda não é não-humano o suficiente ${ }^{73}$.

\subsection{4.}

\section{Cosmoliteratura}

O conceito de devir-animal cunhado por Deleuze e Guattari encontra especial ressonância na arte, sobretudo na literatura de Kafka, como vimos, embora também sejam mencionados filmes como Calafrio (Willard, 1974), pintores como Francis Bacon e mesmo sociedades camponesas e selvagens. Se a arte e, particularmente, a literatura, se abrem como um lugar no qual a relação dos

${ }^{73}$ Eliane Martin-Haag encerra assim seu artigo: "Do ponto de vista que nos interessa, podese dizer que a obra de Kafka marca, segundo Deleuze, o momento em que o devir-animal não é mais suficiente para nos livrar dos agenciamentos do poder, a menos que se acelere a sua fuga e se devenha uma máquina que nos faça imperceptíveis, indiscerníveis e impessoais. É preciso então anunciar a morte do homem e a boa nova da imanência a fim de que cada um aspire a uma individuação impessoal que exclua toda a hierarquia política e ontológica dos graus de ser" (Martin-Haag, 2008, p. 16). 
humanos com os animais adquire um grau elevado de intensidade - pensemos, por exemplo, no que diz Massumi sobre a animalidade da linguagem -, então pode ser interessante perscrutar o que dizem os escritores, ou alguns deles, que vão mais frontalmente ao encontro dos animais. Se um povo menor pode ser invocado pela escrita, em um agenciamento coletivo de enunciação, também é possível que os discursos não-humanos sejam trazidos ao centro da política por meio da literatura.

Há um caso exemplar: o do poeta inglês Ted Hughes, que dedicou boa parte de sua obra ao que se chama "poemas animais" e tem entre seus escritos mais famosos peças habitadas por jaguares, por lúcios e pelo vento. A ressonância, para tomar emprestada o termo usado por Zourabichvili ao caracterizar um devir, dos animais em sua escrita é tal que o levou a afirmar que os animais "tornaram-se uma linguagem - uma linguagem simbólica que é também a linguagem de toda a minha vida" (Hughes, 1995, s/p).

Hughes tem um pequeno livro chamado Poetry in the Making, cujo primeiro capítulo é dedicado à escrita sobre animais. Nele, o poeta conta que, depois de ter passado a juventude caçando todo tipo de bicho a que tinha acesso, seu interesse pelos animais, mantendo-se sempre forte, mudou: "Eu me acusava de perturbar suas vidas. Comecei a olhar para eles, vejam bem, a partir de seu próprio ponto de vista" (idem, 1982, p. 16). Ver do ponto de vista do outro ou "senti-lo sentir em nós" são algumas das maneiras de descrever o processo pelo qual o escritor é atravessado por afetos não-humanos, pelo qual a escrita pode, de alguma forma, encontrar um canal de comunicação intermundos. Hughes chega a afirmar, ao descrever o processo de criação de um poema, que, ao fim dele, "você lerá o que escreveu e vai ter um choque. Você terá capturado um espírito, uma criatura" (idem, p. 19). Um de seus poemas mais famosos, "The Thought-Fox" (O pensamento raposa), de 1955, funciona como um tipo de meta-poema:

The Thought-Fox

I imagine this midnight moment's forest:

Something else is alive

Beside the clock's loneliness

And this blank page where my fingers move.

Through the window I see no star:

Something more near

Though deeper within darkness

Is entering the loneliness:

Cold, delicately as the dark snow 
A fox's nose touches twig, leaf;

Two eyes serve a movement, that now

And again now, and now, and now

Sets neat prints into the snow

Between trees, and warily a lame

Shadow lags by stump and in hollow

Of a body that is bold to come

Across clearings, an eye,

A widening deepening greenness,

Brilliantly, concentratedly,

Coming about its own business

Till, with a sudden sharp hot stink of fox

It enters the dark hole of the head.

The window is starless still; the clock ticks,

The page is printed (Hughes, 1982, p. 19-20). ${ }^{74}$

Nesse poema, praticamente um modelo de devir-animal poético, a raposa pressentida por Hughes vai ganhando, para o escritor, uma concretude cada vez maior até que se torna, de repente, página escrita. "Alguma outra coisa está viva": é a raposa, cada vez mais presente, aproximando-se e contaminando o próprio processo da escrita por uma qualidade raposa; é o pensamento ele mesmo que devém raposa. Sobre o poema, Hughes comentou:

Este poema não tem algo que facilmente se poderia chamar de um sentido. É sobre uma raposa, obviamente, mas uma raposa que é uma raposa e não é ao mesmo tempo. Que tipo de raposa é essa que pode pisar direto dentro da minha cabeça onde presumivelmente ainda está... rindo para si mesma enquanto os cães latem. É tanto uma raposa quanto um espírito. É uma raposa real; à medida que leio o poema eu a vejo se mover, deixar suas pegadas, vejo sua sombra passar por sobre a superfície irregular da neve. As palavras me mostram tudo isso, trazendo-a para cada vez mais perto. É muito real para mim. As palavras fizeram um corpo para ela e a deram por onde andar (idem, p. 20).

Do modo como é, cada vez que eu leio o poema, a raposa vem de novo da escuridão e pisa dentro da minha cabeça. E suponho que muito depois de eu ter-me ido, enquanto uma cópia do poema existir, a cada vez que alguém o ler, a raposa

${ }^{74}$ Uma tradução literal e rudimentar deste poema resulta em algo do tipo: "Imagino a floresta deste momento à meia-noite/Alguma outra coisa está viva/Além da solidão do relógio/E desta página vazia em que meus dedos se movem//Através da janela não vejo estrelas:/Algo mais próximo/Apesar de profundamente dentro da escuridão/Está entrando na solidão//Frio, delicadamente como a neve escura/ Um nariz de raposa toca ramos, folhas/Dois olhos servem um momento, aquele agora/e agora de novo, e agora e agora//Imprime pegadas nítidas na neve/Entre árvores, e cautelosamente uma manca/sombra é atrasada por tocos e em oco/de um corpo que é audaz por passar//Por entre clareiras, um olho,/Um amplo profundo verdor/Brilhantemente, concentradamente/Cuidando de seus afazeres próprios//Até que, com um súbito forte quente fedor de raposa/Entra no buraco negro da cabeça/A janela continua sem estrelas; o relógio tiquetaqueia,/A página está impressa." 
levantar-se-á de algum lugar de dentro da escuridão e virá andando até ele ou ela (idem, p. 16).

A raposa-pensamento é raposa e não é ao mesmo tempo, ela cria um mundo que não é mais o do poeta nem o da raposa real, mas em que uma comunicação entre ambos pode surgir, o "ver do ponto de vista deles", o "senti-lo sentir em mim". Uma aliança entre escritor e raposa. Utilizando mais uma vez o vocabulário deleuzo-guattariano, diríamos que o escritor torna-se raposa ao mesmo tempo em que esta torna-se página escrita, escrita farejante, exsuda seu fedor, mete o focinho fino e molhado por entre as palavras, deixa sua pegada.

Diferentemente do que se passa na caça, a que esses animais são sujeitados ainda hoje em práticas cruéis, a raposa e o escritor se encontram em um tipo de entre-lugar, invocam-se ambos um ao outro, modificam-se. A respeito de um outro animal muito caçado, o cervo, e sua relação com a literatura, o poeta e ambientalista Gary Snyder sugeriu que:

As narrativas são um tipo de rastro que deixamos no mundo. Todas as nossas literaturas são sobras [...] Outras ordens de seres têm suas próprias literaturas. No mundo dos cervos, a narrativa é uma trilha de odores que é transmitida de cervo para cervo, com uma arte de interpretação instintiva. Uma literatura de manchas de sangue, um pouco de urina, um cheiro de estro, um toque de cio, um arranhão numa árvore jovem, e o desejo que se foi. E deve haver uma "teoria da narrativa" desses outros seres - pode ser que ruminem sobre "intersexualidade", ou "crítica da composição" (Snyder, 2005, p. 266).

Le Guin, em "The Author of the Acacia Seeds", também trabalha com essa possibilidade; é, mais uma vez, o encontro entre escritores e animais transformando ambos e transformando o que se entende por literatura. No conto, alguns dos excertos da Revista de Terolinguística que se seguem à tradução das sementes de acácia tratam de literaturas golfinho, pinguim (imperais e de adélia) e mesmo de literaturas vegetais.

O pinguim-imperador, "um pássaro social" mas de "colônias menores e muito mais quietas que as dos de adélia", e cujos "laços [...] são mais pessoais ou sociais", sendo um "individualista", produziria uma literatura de "autores singulares em vez de corais", uma "literatura cinética, mas quão diferente da escrita marinha espacialmente extensiva, rápida e de coros múltiplos" (Le Guin, 2014, p. 8799). O script, roteiro, o meio e o repertório pelo qual a literatura desses "escritores marinhos" que voam pelas águas vem ao mundo é "quase inteiramente escrito em asas, pescoço e ar" (idem, p. 8771). O proponente do estudo sobre a 
literatura dos pinguins-imperadores que escreve o excerto finalmente exorta seus colegas, fazendo referência ao processo pelo qual os pinguins-imperadores chocam os ovos de suas fêmeas:

Imaginem: o gelo, a neve lavada, a escuridão, o lamento e o grito do vento. Naquela desolação negra um pequeno bando de poetas se agacha. Eles estão morrendo de fome; não comerão por semanas. No pé de cada um, sob as aquecidas penas da barriga, jaz um grande ovo, preservado assim do toque mortal do gelo. Os poetas não podem se ouvir; não podem se ver. Podem apenas sentir o calor do outro. Esta é sua poesia, esta é sua arte. Como todas as literaturas cinéticas, ela é silenciosa; diferentemente de outras literaturas cinéticas, é quase imóvel, inefavelmente sutil. O farfalhar de uma pena; o deslocamento de uma asa, o toque, toque leve, tênue e quente daquele a seu lado. Em uma indizível, miserável e negra solidão, a afirmação. Na ausência, presença. Na morte, vida (idem, p. 8799-8813).

"The Author of the Acacia Seeds" possui três partes: a tradução das sementes, a proposta de estudo da poesia do pinguim-imperador e um editorial que lança a possibilidade da compreensão de literaturas vegetais. Le Guin assim alarga a compreensão de literatura, devolve-a ao mundo, aos seres do e no mundo, transformando-a em cosmoliteratura; aquela que é recrutada sempre como uma das maiores distinções da humanidade, a linguagem, é reconceitualizada e impõe um contínuo entre os humanos e outros entes terrenos, inclusive os minerais. $\mathrm{O}$ conto, situando-se em uma época na qual a literatura animal já é amplamente conhecida, isto é, atualizando um futuro de que nosso mundo é um dos passados possíveis, conclui-se com uma provocação:

Lembrem-se de que tão tarde como no meio do século 20, a maioria dos cientistas e muitos artistas não acreditavam que mesmo o Golfinho seria compreensível ao cérebro humano - ou até que valesse a pena ser compreendido! Deixemos outro século passar e nós talvez pareçamos igualmente risíveis. "Você se dá conta", o fitolinguista dirá ao crítico de estética, "de que eles não conseguiam sequer ler Berinjela?" (idem, p. 8846).

O pensamento-raposa cartografa a íntima relação entre escrita e animais um animal, uma raposa singular, mas há nele também a promessa de outros tipos de pensamentos, de sentidos, talvez, animais. O que seria um pensamento-rato? "Há uma baratidade da barata, uma ratidade do rato, e são os estilos dessas assinaturas que entram no ato da escrita" (Massumi, 2015, p. 59). Não são mais o homem e o animal fixados, mas ambos desterritorializados em um contínuo, em uma zona de indiscernibilidade na qual algo de um passa ao outro, ao fim de que a reterritorialização acontece, em uma espécie de antropozoogênese, nas palavras de Vinciane Despret (cf. Despret, 2004b), ou uma "prática de terioantropomorfismo", 
como disse Haraway (Haraway, 2008, p. 375). A escrita, então, e o pensamento ele mesmo tornam-se assim híbridos, escapando para fora de essências e em direção aos encontros que constituem a experiência da vida na Terra. No caso da possibilidade da literatura animal, como aquela dos cervos ou dos pinguins, ela promove uma desterritorialização da própria ideia de literatura, que se abre para aquilo que podem os corpos, para o modo como afetam e são afetados no mundo. Trata-se de olhar com outros olhos - com os olhos dos outros, olhos situados, desligados do "truque de Deus"; não são só os animais que saem desse movimento como produtores de literatura, mas é a própria ideia de literatura humana, do que é escrever, que se transforma. Expressão, certamente, mas uma expressão corporificada, não simplesmente mundana mas mundificadora, criadora de mundos. Escrever passa a ser um modo corporificado de habitar o mundo, não sublime mas implicado nele, sempre relacional.

E qual a relação entre a possibilidade de uma política animal e o caso da literatura? A literatura, em seus devires-animais, explode a propriedade da humanidade, seu lugar de dominação dos outros entes. Ela, ao encontrar animais, ao ser transformada e transformá-los (por exemplo, ao postular a sua literatura), constitui um mundo mais rico, de mais seres e pontos de vista que precisam, a partir deste momento, ser levados em consideração. Ela opera, nas palavras de Stengers, uma mudança cósmica; se o oikos muda pela entrada nele de outros modos e sentidos de habitá-lo, novos ethoi são convidados a surgir. A literatura na sua relação com os animais - com os extra-humanos - é, assim, cosmopolítica, e as questões que ela nos coloca são urgentes: como endereçar esses outros povos? O que eles têm a nos dizer sobre nosso modo vida, sobre nossa relação com eles? Que mundo é esse que será perdido para sempre, aquele do povo poeta dos pinguins-imperadores, com o degelo das calotas polares? Como ficaria a Monsanto caso pudéssemos ler Berinjela?

\subsection{5.}

\section{"Think my way into the existence of a being"}

A segunda conferência que Elizabeth Costello pronuncia em $A$ vida dos animais, de Coetzee, chama-se "Os poetas e os animais." A narrativa da novela não permite que o leitor a acompanhe em sua inteireza, como havia sido o caso da 
palestra anterior, "Os filósofos e os animais", talvez porque a filosofia mantenha com os animais uma relação de mais oposição que a poesia e precise ser abordada mais frontalmente. Derrida, em $O$ animal que logo sou, distinguia o filosofema, discurso que se funda na separação entre homens e animais, partindo de um ponto de vista que olha para os animais sem ser por eles vistos, do poema - ou da profecia -, enunciado por aqueles e aquelas "que confessam tomar para si a destinação que o animal lhes endereça" (Derrida, 2002, p. 34). Mas talvez mesmo entre os poetas haja divergências; sobre Costello, aquilo que Coetzee nos permite ler de sua conferência é a conclusão, na qual ela opõe Rilke, um poeta favorito dos filósofos, a Ted Hughes, por meio de seus célebres poemas "A pantera" e "O jaguar." A escritora explica:

Hughes escreve contra Rilke [...] Usa o mesmo cenário do zoológico, mas, para variar, é a multidão que fica hipnotizada e, entre as pessoas, o homem, o poeta, em transe, horrorizado e assombrado, seu poder de compreensão levado além do seu limite. A visão do jaguar, diferente da visão da visão pantera, não é desfocada. Ao contrário, seus olhos perfuram o escuro do espaço. A jaula não tem realidade para ele, ele está em outra parte. Está alhures porque sua consciência é mais cinética que abstrata: a força de seus músculos o leva a um espaço de natureza muito diferente da caixa transdimensional de Newton - um espaço que gira em torno de si mesmo (Coetzee, 2009, p. 60).

O poema de Rilke fala de um lugar específico: "no jardim das plantas", isto é, no jardim fundado em 1626 por um decreto real e que ganhou o nome atual depois da Revolução Francesa. A pantera que ele canta, portanto, é uma pantera moradora de um zoológico real de Paris e que provavelmente foi observada pelo poeta. Há na revista francesa L'Illustration, em edição de 1902, cinco anos antes da escrita do poema, uma gravura que mostra animais, justamente grandes felinos, e artistas no jardim. O que se vê são um par de leões e um tigre em minúsculas celas áridas, separados por grades de pessoas que enchem o lado de fora com seus cavaletes de desenho, inclusive uma mulher, além de um homem que procura chamar a atenção do tigre - ou provocá-lo - brandindo um pequeno lenço de pano bem perto de sua cabeça. Será que Rilke, a certa altura, compôs esse cortejo quase multitudinário formado por artistas e curiosos? Ou será que os observou sozinho, em algum momento em que o zoológico estava mais vazio? Não foi possível encontrar nenhuma informação a respeito da pantera ou panteras, onde nasceram, de onde e como foram transportadas, a que espécie e subespécie pertenciam, se tinham nomes, quanto tempo ali viveram, em que condições etc. Críticos e estudiosos não costumam se interessar por essas questões e, assim, a musa de 
Rilke permanece misteriosa. De todo modo, sobre essa pantera que não se sabe se jaguar ou leopardo, os dois animais normalmente referidos por essa designação, ele escreveu:
A Pantera
No Jardin des Plantes, Paris
De tanto olhar as grades seu olhar esmoreceu e nada mais aferra.
Como se houvesse só grades na terra:
grades, apenas grades para olhar
A onda andante e flexível do seu vulto em círculos concêntricos decresce, dança de força em torno a um ponto oculto no qual um grande impulso se arrefece.
De vez em quando o fecho da pupila se abre em silêncio. Uma imagem, então, na tensa paz dos músculos se instila para morrer no coração (Rilke apud Campos, 2001, p. 57)

Agora é possível imaginar: naquela pequena cela, de frente a uma tropa de artistas e curiosos, a pantera caminha em círculos. Talvez as "grades, apenas grades para olhar" refiram-se às colunas formadas por humanos postados depois das grades de ferro: não há lado de fora. Como os animais confinados “em condições degradantes", conforme os descrevia de Waal, e que se entregam a comportamentos estereotipados, isto é, aqueles que sugerem um desespero ou loucura, a pantera caminha em círculos. De repente, uma esperança: "uma imagem, então, na tensa paz dos músculos se instila" - que imagem seria essa? O que a pantera, de dentro do círculo infernal a que foi sujeitada a habitar, poderia ver? Um momento de lucidez? Uma saída desse círculo? O que quer que seja, não dura muito, pois isso vai logo "morrer no coração." É possível, no entanto, que esses pequenos momentos, "de vez em quando", quando "o fecho de sua pupila se abre em silêncio" e ela vê alguma coisa, signifiquem que a pantera enjaulada, quase louca, não está derrotada.

Para Costello, entretanto, a história é outra e Rilke não teria ido

além da pantera como a encarnação de um tipo de força que é liberada em uma explosão atômica, mas que aqui está contida, não pelas barras da jaula, como por aquilo que as barras produzem na pantera: um andar em círculos concêntricos que deixa a vontade aturdida, narcotizada (Coetzee, 2009, p. 60).

Em seguida ela deixa claro que não pretende, ao criticar "A pantera" enaltecendo "O jaguar", entrar "no aspecto ético de se enjaular animais de grande porte" 
(idem). Mas a lembrança de que se trata de uma cena no Jardin des Plantes não pode deixar dúvida: trata-se da pantera contida, encarcerada, sem refúgio, forçada a ser vista o tempo todo. Talvez a questão diga respeito justamente ao aspecto de se enjaular animais. O poema de Rilke pode ser lido de muitos modos, é claro, mas um deles é aquele da captura de um momento da zona de indistinção na qual a patológica política humana encerra os animais. "A pantera" é certamente uma imagem desse mundo. $\mathrm{O}$ poeta e tradutor Augusto de Campos não entra nesse aspecto, mas louva o poema porque "mais do que descreve, se introscreve nos outros", fazendo com que "o eu desapareça para que, através da captação da figuralidade essencial do outro, com um mínimo de adjetivação e um máximo de concretude, aflore uma dramaticidade imanente, insuspeitada" (Campos, 2001, p. 29). "A pantera", segundo essa leitura, é um poema que se poderia inscrever no tipo dos poemas de devir-animal, no qual Rilke, "o poeta, se pantera" (idem). Panterizar-se aí, como costuma ser o caso em um devir, não diz respeito às panteras em geral, mas àquela pantera e seu pequeno e miserável mundo. Uma pantera. Um animal de zoológico.

De todo modo, não é nada simples recusar a crítica de Costello ao poema de ao Rilke e é bem possível que ela surja de uma leitura mais extensa de sua obra e da compreensão do estatuto dos animais nela. Um lugar muito apropriado para observar a visada do poeta sobre os animais é o conjunto de poemas "Elegias de Duíno", de 1923, onde surge a questão do "aberto", depois retomada por Martin Heidegger e Agamben. No ensaio "Para quê poetas", ao glosar sobre o assunto, Heidegger cita uma carta de Rilke sobre a oitava elegia, na qual o escritor afirma que

O animal está no mundo. Nós ficamos diante dele através da viragem e do desenvolvimento característicos da nossa consciência [...] O "aberto" não se refere, portanto, ao céu, ao ar ou ao espaço, também eles são, para quem observa e julga, "objectos", logo "opaques" e fechados. O animal, a flor, admitamo-lo, é tudo isso, sem se dar conta, e tem, por isso, diante de si e sobre si esta liberdade indescritivelmente aberta [...] (Rilke apud Heidegger, 2002, p. 328).

Segundo essa glosa, portanto, a consciência humana produziria uma espécie de dobra que separa os homens do mundo; já o animal - ou as plantas - estariam inteiramente dentro dele, sem a possibilidade de um movimento reflexivo. O aberto na verdade é portanto uma prisão. Assim, de acordo com a carta, quando Rilke diz em seu poema que 
Com todos os olhos vê a criatura

o Aberto. Só os nossos olhos estão

como invertidos e de todo postos à volta dela

como armadilhas, em círculo à volta de sua saída livre.

O que está lá fora, só o sabemos da face

do animal [...] (Rilke, 1983, p. 216)

- no que poderia parecer quase uma retomada de "A pantera" ("nossos olhos [...] à volta dela como armadilhas, em círculo à volta de sua saída livre") -, o que está em jogo na verdade é o modo como o homem consegue se posicionar fora do mundo, algo de que as "criaturas" seriam incapazes, paradoxalmente presas no aberto para todo o sempre. Retrospectivamente, então, e ainda tomando essa elegia como chave de leitura, um dos modos pelos quais "A pantera" poderia ser lido é justamente como a descrição de um animal preso, no sentido de que todos os animais o são. Seguindo com a oitava elegia, nela se lê ainda que o animal é "livre da morte" (idem), encontra-se fora do tempo e completamente encerrado na natureza: "Ó ventura da pequena criatura que fica sempre no seio que a gerou" (idem, p. 218). Só os humanos, o que é de certa forma lamentado pelo poeta, habitam essa espécie de dobra ou viragem (“quem é que assim nos virou?", idem) que os torna "espectadores" (idem), isto é, sujeitos e juízes. Pode-se dizer que o animal rilkeano é sublime, quase uma presença angelical no mundo. Ele chega a experimentar "uma grande melancolia", a saber, "a lembrança,/ como se aquilo para que tendemos já alguma vez/ tivesse estado mais perto, mais fiel, e a ligação a ele/ infindamente terna" (idem, p. 217-218). Saudade do Éden.

Heidegger comenta o poema: “O 'no' [“o animal está no mundo"] significa: inseridos obscuramente na rede de feixes da conexão pura" (Heidegger, 2002, p. 329). E se o filósofo critica Rilke, afirmando que sua poesia ficou "na sombra da metafísica atenuada de Nietzsche" (Heidegger, 2002, p. 329), insinuando que o poeta nada mais teria feito além de inverter a metafísica platônica, ele também aprisiona o animal, desta vez fora do aberto entendido como a clareira do ser. E o faz, nesse caso, por outro tipo de inversão, agora do próprio Rilke - uma “transformação essencial”, como a nomeia Agamben (Agamben, 2007, p. 107), que continua, fazendo referência aos animais angelicais do poeta: "É precisamente esta relação de inversão hierárquica entre o homem e o animal que Heidegger põe em questão" (idem, p. 108), Como se sabe, para Heidegger o homem não pode ser definido como "animal rationale", como costuma alegar a metafísica, mas deve 
ser pensado em direção à sua humanitas (cf. Heidegger, 1990). E o animal, pobre de mundo, justamente, é quem não pode jamais ver o aberto - que, para Heidegger, é outro nome para alétheia compreendida como o "velamentodesvelamento do ser" (idem). "O homem é o pastor do ser" (Heidegger, 1990, p. $88)$.

Poderíamos perseguir esse vasto caminho, mas já sabemos aonde ele leva ${ }^{75}$. Por ora, fiquemos com Agamben, que, ainda procurando conciliar a vida e a existência dos animais com a filosofia de seu mestre, dirá, em $O$ aberto:

Enquanto o animal não conhece ente nem não ente, aberto nem fechado, ele está fora do ser, em uma exterioridade mais externa que todo o aberto e dentro em uma intimidade mais interior que todo o fechamento. Deixar ser o animal significará então: deixá-lo ser fora do ser. A zona de não-conhecimento - ou de ignoscência aqui em questão_está além tanto do conhecer quanto do não-conhecer, tanto do desvelar quanto do velar, tanto do ser quanto do nada. Mas o que é assim deixado fora do ser não é, por isto, negado ou removido; não é por isso não existente. É um existente, um real, que foi mais além da diferença entre o ser e o ente (idem, p. 166-167).

Mas ali onde Agamben propõe que se deixe ser ou estar o animal fora do ser, meio à moda do "Let it be" que Lennon e McCartney consideravam "palavras de sabedoria", Elizabeth Costello prefere explorar "um diferente modo de ser-nomundo" (Coetzee, 2009, p. 66) - a escritora não está pronta para baixar suas armas. E, para tanto, de modo a chegar a esses diversos modos de ser-no-mundo, ela aciona o conceito de "imaginação simpática", descrito como um "penetrar com o pensamento na existência [think my way into the existence of]" (idem, p. 43) de outrem. Sendo uma escritora, ela explica, seu ofício mesmo baseia-se em adentrar com o pensamento na existência de outros seres que jamais existiram; se é possível imaginar alguém que jamais foi de fato, personagens em romances, contos e outros, entrar nessas existências de modo simpático, ela conclui, há de ser factível que se faça o mesmo com "qualquer ser que participe comigo do substrato da vida" (idem). O conceito costelliano de imaginação simpática, assim descrito, faz ressoar a discussão encetada em nosso segundo capítulo acerca do instinto criador, sobretudo quando comentávamos que Massumi traz Bergson à baila para dizer, junto com ele, que haveria um "esforço de intuição" e "uma espécie de simpatia" na intenção artística que tornaria possível penetrar o "interior do objeto" (Bergson, 1909, p. 192) - um exemplo do "modo de existência do

75 Para a relação entre o pensamento de Heidegger e os animais, cf. Heidegger, 1997; Buchanan, 2008; Romano, 2009; Bailey, 2011; Valentim, 2013. 
terceiro incluído" (Massumi, 2014, p. 35). Além disso, Massumi lembra Bergson mais uma vez ao citá-lo dizendo que instinto é simpatia. Costello, então, se seguirmos essa pista, ao reclamar a simpatia como uma "faculdade [...] que, às vezes, nos permite partilhar o ser do outro" (Coetzee, 2009, p. 43), estaria, assim, situando a literatura no âmbito do instinto - aquele tipo de resposta criadora, que sempre supera o dado e se constitui como uma faculdade plástica da vida.

É Ted Hughes o sujeito da imaginação simpática que Costello vê tateando em direção a ("feeling his way toward") um outro tipo de ser-no-mundo quando escreve um poema como "O jaguar":

Macacos se espreguiçam cultuando pulgas ao sol. Guincham os papagaios, como ardendo, ou gingam Feito putas a fim de atenção e amendoim.

Fatigados pela indolência, o tigre e o leão

Jazem imóveis como o sol. O rolo da jiboia Fossiliza-se. Jaula após jaula está vazia, ou Fede ao palheiro onde tresanda um dorminhoco. Para pintar num quarto de criança a cena é boa.

Mas quem percorre a ala com os outros atinge A jaula onde uma multidão vem ver, mesmerizada Como criança sonhando, um jaguar furioso a girar Pelo breu da prisão que a broca do seu olhar punge

Num curto pavio feroz. Sem fastio Os olhos contentes no seu fogo cegante, Os ouvidos ao surdo tambor do seu sangue Revolta-se ante as grades, mas para ele não há jaula

Mais do que para o visionário existe sua cela:

É seu passo o sertão que a liberdade tem defronte:

O mundo rola embaixo do ímpeto de suas patas.

No chão de sua jaula se derramam os horizontes (Hughes, 2010, p. 40).

O cenário é semelhante ao do poema de Rilke, mas as coisas aqui se passam de modo diverso. Em vez de se dissolver em um movimento concêntrico, o jaguar de Hughes sente nos ouvidos "o surdo tambor de seu sangue" - ele é um corpo que pulsa, com sangue quente e olhos de fogo. O jaguar também gira, mas o que seu giro parece exprimir não é mais um comportamento estereotipado, senão uma fúria. Diferentemente da pantera, cujas imagens que se mostram em seus olhos são exceção e logo morrem, o jaguar força, com seu olhar de broca, de um fogo cegante, a sua perspectiva no mundo, dissolve as barras e os espectadores: "no 
chão de sua cela se derramam os horizontes." Enquanto a pantera talvez não esteja ainda derrotada, a possibilidade da derrota ou da entrega não existe para o jaguar.

Costello vê no poema um jaguar-corpo em vez de uma pantera-abstração, pantera-movimento, como era o caso do poema de Rilke. O poema, ela diz, "pede para nos imaginarmos naquele jeito de se mover, nos pede para habitar aquele corpo" (Coetzee, 2009, p. 60). Estamos mais uma vez no terreno dos animais inclusive o humano - definidos por aquilo que eles podem, pelas possibilidades de seus corpos. $\mathrm{O}$ poema de Hughes convida a um devir-jaguar na medida em que transporta a escrita para o corpo do animal; é o poema que pulsa, se inflama. "Em Hughes", a escritora continua, "não se trata, insisto, de habitar outra mente, mas de habitar outro corpo" (idem, p. 61). Em lugar de uma abstração, penetrar com o pensamento a existência de outro significa conduzir-se até seu corpo, experimentar sua perspectiva. Trata-se, assim, "de uma poesia que não tenta achar uma ideia no animal, que não é sobre o animal, mas sim, ao contrário, o registro de um compromisso com ele" (idem, grifo meu). Talvez mais que escrever "diante dos animais", como propunham Deleuze e Guattari, Costello apresente um modo poético que se constitui como um pacto com eles. Hughes pertenceria, assim, a uma tradição poética que "repudia a tendência ocidental para o pensamento abstrato" (idem, p. 62), da qual também fariam parte Blake, Lawrence e Snyder, e o que ele mostra, ensinando "mais do que sabe" (idem, p. 63), é que

nós também podemos encarnar em animais, pelo processo chamado invenção poética, que mistura alento e sentido de uma forma que ninguém jamais explicou, nem explicará. Ele nos mostra como trazer à vida o corpo vivo dentro de nós mesmos. Quando lemos o poema do jaguar, quando depois o relembramos, com tranquilidade, por um breve instante nos transformamos no jaguar. Ele estremece dentro de nós, toma posse de nosso corpo. Ele é nós (idem).

Usando as palavras do escritor, a cada vez que o poema é lido, o jaguar se ergue de algum lugar - talvez a jaula que para ele não existe - e mais uma nos conduz até seu corpo.

"Aulas de poesia", Costello admite para seu filho mais tarde na novela, não são capazes de "fechar os matadouros" (idem, p. 69), mas ela não quer - não pode - "ficar sentada, calada" (idem, p. 71). A escritora, como Derrida, acredita que vivemos em guerra contra os animais, uma guerra travada por toda a história e que para ela tem sido vencida pelos humanos que inventaram as armas de fogo. Mas, embora ela, e Coetzee, por ela, não acreditem que o ensino de poesia pode fechar 
matadouros, dedicam conferências - ela - e uma novela inteira - ele - a respeito da relação entre humanos e animais. É muito provável que aulas de poesia não mudem a situação dos animais no mundo, mas a poesia, ou a literatura de Coetzee e as conferências de Costello funcionam como uma espécie de artefato que se infiltra no mundo, traz novas articulações e modos de ser-no-mundo; e esse movimento não pode ser desfeito. Ele contamina, penetra a existência de outros seres, opera eventos cósmicos virtuais e atuais. É aí que jaz a força de sua obra, a força de "não ficar sentada, calada."

\subsection{6.}

\section{Sultão}

No começo de A vida dos animais, Costello apela ao Pedro Vermelho de Kafka, mas, em vez de aproximar sua vida da de Consul, como faz Baratay, segue outra direção. O ex-macaco, em seu relato, falava no circo e no teatro de variedades como destinos possíveis a partir do navio à vapor Hagenbeck, mas sem mencionar as instituições de pesquisa, como a Pastoria a que aludimos no segundo capítulo, da qual talvez não encontrasse saída, principalmente se fosse destinado à pesquisa médica. É sobre esse tipo de instalação que se debruçará Costello, mas voltando-se aos experimentos cognitivos, em particular aqueles realizados pelo psicólogo Wolfgang Köhler em chimpanzés quando trabalhou como diretor da estação de pesquisa de antropoides da Academia Prussiana de Ciências, entre 1913 e 1920 (cf. Ruiz e Sanchez, 2014). A estação localizava-se em Tenerife, uma das ilhas que formam o arquipélago das canárias, cuja colonização pelos espanhóis data do final do século XV e envolveu uma longa resistência dos povos guanches que viviam ali pelo menos desde 1000 a.C. Ainda nas primeiras décadas do século XVI, os nativos daquela ilha foram escravizados e as florestas de Tenerife devastadas pela introdução da monocultura, sobretudo de cana-de-açúcar (cf. Cabrera, 1982). Em 1912, a estação de antropoides da Academia Prussiana de Ciências foi instalada ali com o propósito de conduzir uma "observação símia antropomórfica” (Rothman apud Ruiz e Sanchez, 2014, p. 2) em uma localidade próxima à Europa mas com clima propício à vida dos animais, que poderiam ser tanto africanos quanto asiáticos, de modo que se pudesse comparar suas "vidas mentais e atividades", com a garantia do "fornecimento de materiais os mais 
baratos possíveis" (idem, p. 3). Os símios seriam transportados para Tenerife passando por Camarões, então uma colônia alemã, e através de Tânger, “onde os grandes navios a vapor alemães atracam em direção à Ásia" (idem). Sultão, que viria a se mostrar a mais hábil das cobaias, provavelmente veio de Camarões, tendo chegado à ilha em 1912 para compor um conjunto de sete chimpanzés inclusive um chamado Consul - destinados à pesquisa, que eram cuidados por um homem nativo conhecido como "Manoel dos macacos", responsável por alimentálos e os limpar, além de ajudar no preparo dos experimentos que seriam conduzidos pelos pesquisadores (cf. idem).

Um desses experimentos, para testar "se [os animais] comportam-se ou não com inteligência e insight sob circunstâncias que requerem tal comportamento (Köhler apud Ruiz e Sanchez, 2014, p. 6), consistia em posicionar o animal em uma espécie de terreiro fechado no qual uma cesta de frutas ficava presa por uma corda em um anel de dois metros, com a outra ponta amarrada em um galho de árvore; Sultão, o chimpanzé escolhido, puxou a corda e teve acesso às frutas, que caíram ao bater no anel. Mas Köhler acreditava que a solução mais fácil teria sido desamarrar a corda para soltar a cesta e que, portanto, "as condições desse experimento eram complicadas demais para asseverar o que causou o comportamento observado, e então ele continuou a estudar situações mais simples" (Ruiz e Sanchez, 2014, p. 7). Essas "condições [...] complicadas", por outro lado, significavam que o sujeito experimentado tinha a possibilidade de escolher que decisão tomar, mesmo diante de um problema que envolvia a privação de comida. Köhler passou depois disso a desenvolver dispositivos com apenas um tipo de solução: apanhar as frutas subindo em caixotes, movendo-os ou usando um pedaço de pau para balançar algo, de modo cada vez mais complicado, mas não no sentido de que o chimpanzé pudesse escolher o que fazer, e sim que fosse necessário cumprir vários desses passos até ter acesso às frutas. Diversos desses experimentos foram filmados e até hoje estão disponíveis, por exemplo, na internet. Em um deles, um indivíduo que se presume ser Sultão, localizado sob uma espécie de lona de circo, sobre um chão de terra batida, levanta um caixote e o põe em cima de outro, depois de algumas tentativas e erros, até alcançar a fruta pendurada no teto. Em um segundo, ele ou outro chimpanzé encaixa um pedaço de pau em outro, formando uma espécie de lança comprida, com a qual move frutas que se encontram entre ele e uma grade. Em um terceiro, ainda, diversos 
chimpanzés se ajudam mutuamente, uns movendo caixotes e os mantendo firmes, enquanto outro, com o pedaço de pau, bate nas frutas no alto.

O que Costello faz, por meio da invenção poética, é penetrar a existência do hábil Sultão e imaginar seus estados mentais e reflexões enquanto era submetido aos dispositivos desenvolvidos por Köhler, em busca de sua perspectiva, tentando pensar dentro de um corpo de chimpanzé. O resultado é tão assombroso que vale a pena ler o trecho inteiro:

"Sultão está sozinho em seu cercado. Está com fome: a comida, que costumava chegar com regularidade, inexplicavelmente deixou de vir.

"O homem que costumava alimentá-lo, e que agora parou de fazê-lo, estica um fio três metros acima do chão de seu cercado e nele pendura uma penca de bananas. Arrasta para dentro do cercado três caixotes de madeira. Depois desaparece, fechando o portão, mas permanecendo nas proximidades, pois é possível sentir seu cheiro.

"Sultão sabe: agora é preciso pensar. Por isso as bananas estão ali no alto. As bananas estão ali para fazer pensar, para empurrar o sujeito até os limites do pensamento. Mas o que se deve pensar? Algo como: por que ele está me deixando passar fome? Ou: o que foi que eu fiz? Por que ele parou de gostar de mim? Ou ainda: por que ele não quer mais esses caixotes? Mas nenhum desses é o pensamento correto. Até um pensamento mais complicado - por exemplo: qual é o problema dele, que conceito errado ele faz de mim que o leva a acreditar que é mais fácil para mim chegar até uma penca de bananas pendurada num fio do que pegar as bananas do chão? -, até isso está errado. O pensamento certo é: como usar os caixotes para chegar às bananas?

"Sultão arrasta os caixotes até posicioná-los sob as bananas, empilha um em cima do outro, sobe na torre que construiu e pega as bananas. Pensa: será que agora ele vai parar de me castigar?

"A resposta é: não. No dia seguinte, o homem pendura outra penca de bananas no fio, mas também enche os caixotes de pedras, de forma que fiquem pesados demais para arrastar. O que se deve pensar não é: por que ele enche os caixotes de pedras? $\mathrm{O}$ que se tem de pensar é: como se faz para usar os caixotes para pegar as bananas, apesar de estarem cheios de pedras?

"Dá para começar a entender como funciona a cabeça do homem.

"Sultão remove as pedras de dentro dos caixotes, constrói uma torre com os caixotes, sobe na torre, pega as bananas.

"Enquanto Sultão continuar tendo os pensamentos errados, passará fome. Até a sua fome ser tão intensa, tão avassaladora, que ele se veja forçado a ter o pensamento correto, isto é, como conseguir pegar as bananas. Assim são testadas até o limite as capacidades do chimpanzé

"O homem põe uma penca de bananas um metro para fora da malha de arame do cerrado. Joga uma vara para dentro do cerrado. O pensamento errado é: por que ele parou de pendurar as bananas no fio? O pensamento errado (o pensamento erradocorreto, todavia) é: como usar os três caixotes para pegar as bananas? O pensamento correto é: como usar a vara para pegar as bananas?

"A cada vez, Sultão é levado a ter o pensamento menos interessante. Da pureza da especulação - por que os homens se comportam assim? - ele é impiedosamente impelido ao raciocínio mais baixo, prático, instrumental - como usar isto para conseguir aquilo? - e assim à aceitação de si mesmo primordialmente como um organismo com um apetite a ser satisfeito. Embora toda a sua história, desde o momento em que sua mãe foi morta e ele foi capturado, passando pela viagem 
numa jaula até a prisão neste campo, desta ilha, e os jogos sádicos que ali se realizam com a comida, tudo o leva a questionar a justiça do universo e o lugar que nele ocupa esta colônia penal, na qual um regime psicológico cuidadosamente planejado o leva para longe da ética e da metafísica em direção ao humilde domínio da razão prática. E de alguma forma, ao palmilhar esse labirinto de constrangimento, manipulação e duplicidade, ele tem de entender que de jeito nenhum pode ousar desistir, porque em seus ombros repousa a responsabilidade de representar a essência macacal. $O$ destino de seus irmãos e irmãs pode ser determinado pelos resultados que ele obtiver (idem, 34-36).

"A cada vez", diz Costello, "Sultão é levado a ter o pensamento menos interessante." Esta não é apenas uma denúncia da pobreza dos dispositivos experimentais, mas também uma crítica à ideia dos pesquisadores sobre o que constitui a inteligência ou o modo de habitar o mundo pelos chimpanzés. Com fome, sem compreender o que pretende o cientista, lançado no meio de uma situação sem explicação, mais uma, se contarmos sua captura e transporte, o animal deve usar todas as suas forças para fazer exatamente o que se quer dele sob pena de passar fome. E é em meio a esse cenário no qual Sultão é muito mais paciente que agente - ele passa sua vida aguardando aquilo que lhe será imposto , que se urdirá o destino de seu povo. Se ele não for bem-sucedido, é sobre toda a chimpanzidade que cairão as consequências; é cada chimpanzé, desde Sultão, que vai se tornar desinteressante ou interessante, inteligente ou não, distante ou próximo da humanidade etc. a partir dali. Mas em seu íntimo, Costello imagina, embora ele diligentemente, com fome e sem saída, realize os desafios que lhe são impostos, em seu coração mesmo, Sultão pensa diferentemente:

No seu ser mais profundo, Sultão não está interessado no problema da banana. Só a mente do experimentador, obsessivamente voltada para o problema, é que o força a se concentrar nele. A questão que realmente o ocupa, como ocupa o rato e o gato e qualquer outro animal aprisionado no inferno de um laboratório ou de um zoológico, é a seguinte: onde está a minha casa e como chego lá? (idem, p. 36).

A essa pergunta ele nunca encontrará resposta, jamais tendo voltado para casa. Sua vida, como a de Pedro Vermelho e a de Consul, foi profundamente mudada, irreversivelmente, a partir do instante em que foram encontrados por homens que se chamavam a si mesmos de cientistas.

“Dá para começar a entender a cabeça do homem” é um outro pensamento que a escritora capta do animal. E a cabeça do homem, ali, sob o signo do que ele ancestralmente considera ser a razão, é pouco imaginativa, além de pouco compassiva. Cruel, poderíamos dizer. A respeito da razão, Costello guarda ainda 
uma ou duas observações. No final de $A$ vida dos animais, em um movimento semelhante àquele de "The Old Lady and the Cats" no qual confessava sua aliança com o povo dos gatos contra o povo dos humanos, afirma não ter certeza de estar com a razão e nem sequer se o que compreende por razão se diz no mesmo sentido em que o dizem seus oponentes:

Não se a razão constitui a base de toda a tradição filosófica [...] que vem desde Descartes e, além de Descartes, desde Aquino e Agostinho e os estoicos e Aristóteles. Se a única coisa que tenho em comum com ele [seu oponente] é a razão, e se é a razão que me distingue do bezerro, então eu agradeço, mas muito obrigada, prefiro conversar com outra pessoa (Coetzee, 2009, p. 80).

Alguns instantes antes, ela declarava que, se o melhor que a filosofia pode oferecer como pensamento sobre os animais é que eles não entendem a morte, "preferia ir viver entre cavalos" (idem, p. 78). A escritora é a primeira da série de autores convocados nesta tese a assumir uma posição contrária à da razão em vez de procurar nela uma saída; ela parece mesmo preparada, diante dos limites da racionalidade, a abandoná-la. Se a razão é o fundamento espiritual da autoidentificação do humano, aquilo que permite ao humano se identificar como algo único - "se a única coisa que tenho em comum com ele é a razão e se é a razão que me distingue do bezerro" -, então não há caminho possível para o reconhecimento da existência - o "modo diferente de ser-no-mundo" - dos animais. Nesse sentido, talvez a escritora aceitasse a tese de Massumi de que a linguagem e, por conseguinte, a escrita devem ser entendidas como expressões do instinto. Escrever ou fabular não seriam portanto atos racionais, mas animais, na medida em que o humano faz parte do continuum da vida. A razão, por outro lado, na medida em que funda o filosofema derridiano, seria uma espécie de faculdade do desconhecimento ou uma capacidade de negar a vida em si mesmo e nos outros. Aquilo que os três chimpanzés convidados pela escrita neste capítulo, Pedro Vermelho, Consul e Sultão, dão como testemunha é a profundidade desse desconhecimento, além de suas torturantes consequências. 


\section{2.}

\section{Ciência}

\subsection{1. Cabeça (de homem)}

Diante das objeções que Costello faz à razão, e de modo a que não pareçam levianas, é interessante situá-las naquele que é um dos momentos cruciais de sua história, a saber, o momento no qual Descartes, também em nome dessa faculdade, retira o homem do continuum da vida e transforma os animais em máquinas. Essa história pode começar com a famosa anedota sobre Fontenelle segundo a qual este, em uma visita a Malebranche, teria gritado de compaixão ao presenciar o padre-filósofo chutar o ventre da cadela grávida que buscava conforto a seus pés. Malebranche, então, teria the respondido "friamente": "O quê, você não sabe que isso não sente nada?” (Trublet apud Ribard, 2003, p. 141).

O horror de Fontenelle refere-se, claro, à aplicação ao cotidiano, por Malebranche, da tese cartesiana das bestas-máquinas ${ }^{76}$. Conforme testemunhos do século XVII, essa tese configurava-se como a "pedra de toque" do comprometimento de alguém com o cartesianismo, opinião compartilhada tanto por seguidores como por detratores de Descartes. Antoine Dilly, autor de De l'âme des bêtes ou après avoir démontré la spiritualité de l'âme de l'homme, l'on explique par la seule machine, les actions les plus surprenantes des animaux, de 1676, obra popular à época e que chegou a ter pelo menos mais uma edição, em 1691 (Barbier, 1806, p. 389), destacava, logo no prefácio de seu livro, “a ligação estreita que esse ponto particular [a tese das bestas-máquinas] tem com os principais fundamentos de sua [de Descartes] metafísica e de sua física" (Dilly, 1676, s/p); para Gabriel Daniel, em Voyage du Monde de Descartes, "só esse

${ }^{76}$ Embora a tradução de bêtes para animais ou bichos seja mais natural à língua portuguesa, manterei o termo bestas-máquinas por dois motivos: primeiro porque, não tendo almas, falar em animais-máquinas é um oximoro; segundo, para apontar a proximidade entre os conceitos de bestas, besteira e bestialidade (bêtes, bêtise e bestialité), tratados profundamente por Derrida em $A$ besta e o soberano. Derrida aponta para a peculiaridade de que a palavra bête não suscitou na língua francesa um substantivo que designasse o ser ou a condição das bestas (bichos), o que ficou a cargo da palavra animal, da qual se originou "animalidade". O correspondente para o termo bestas seria, talvez, bêteté (bestidade), do qual a palavra mais próxima em português é "bestialidade", substantivo que jamais designaria a condição de um animal, mas apenas de certos humanos; o mesmo se vê quando o substantivo besta torna-se adjetivo: nenhum animal pode ser "besta": "O que é próprio à besta, se isso existe, não é nem a besteira nem a bestialidade. Nem besteira nem bestialidade, a qual [a besteira], se acreditarmos naquilo sobre o qual a filosofia mais faz barulho, é o que é próprio do homem, como o bom senso, a coisa mais bem distribuída no mundo entre humanos" (Derrida, 2009, p. 192). 
ponto contém ou supõe todos os princípios e todos os fundamentos da seita. [...] Eis aí o espírito e o suco, se ouso me exprimir assim, do puro cartesianismo" (Gabriel, 1702, p. 430).

A filósofa Sophie Roux, em um artigo de 2013 que pretende responder à pergunta “O que quer dizer ser cartesiano?”, considera essa querela um lugar privilegiado para entender em que consistiam as principais diferenças entre cartesianos e não-cartesianos, pela maneira como nela aparecem dois eixos principais da recepção da obra, o público e o teológico. De um lado, a tese das bestas-máquina "revelava o caráter contra-intuitivo" (Roux, 2013, p. 8) da ontologia de Descartes de modo muito mais claro que as Meditações; d'outro, ela punha um problema: se os animais não têm alma, no limite é possível que os homens também não a tenham.

Contra ideias escolásticas que remontavam a Aristóteles, Descartes nega a existência de alma (de qualquer tipo) a todos os viventes exceto o homem: só existe um tipo de alma, que é imortal e exclusiva a cada indivíduo humano. Com isso, o filósofo rompe com dois pontos fundamentais da tradição. O primeiro, a tese da metempsicose ou transmigração das almas, ideia presente de Pitágoras a Platão, que supunha que uma mesma alma viria, no decurso dos ciclos de vida e morte, habitar diferentes espécies ${ }^{77}$. E o segundo, o contínuo existente entre os seres vivos; quer fosse dotando os animais de uma alma racional, tripartindo a alma humana ou dividindo-a em almas vegetativa, sensível e racional, a ruptura

77 O final do Timeu, nesse sentido, é exemplar ao expor um tipo de "teoria da evolução reversa", na qual o homem, o vivente mais perfeito, vai dando lugar a formas de vida inferiores - a primeira delas, a mulher: "Dos homens nascidos, os que se revelaram pusilânimes ou durante a vida só praticaram injustiças, com toda a probabilidade foram transformados em mulheres na segunda geração [...] A tribo dos pássaros provém da mudança de forma, com o nascimento de penas em lugar de cabelos, desses indivíduos inofensivos porém frívolos, e dados ao estudo das coisas celestes, e que em sua simplicidade chegam a imaginar que as mais seguras provas em tais assuntos são alcançadas por meio da vista. Os animais ferozes da terra provêm dos homens que nunca se ocuparam com a filosofia nem nada compreenderam da natureza do céu, por não fazerem uso algum das revoluções que se operam na cabeça, só se deixando guiar pelas partes da alma residentes no peito. Em decorrência desses hábitos, os membros anteriores e a cabeça foram atraídos pela terra, em virtude da afinidade existente entre eles, e nela se apoiaram; o crânio alongou-se e adquiriu as mais variadas formas, à medida que os círculos da alma se deformavam pela ociosidade. Essa raça nasceu com quatro ou mais pés, pela seguinte razão: é que a divindade proveu os menos inteligentes com maior número de bases de sustentação, para que fossem arrastados ainda mais para a terra. Porém os mais atrasados dentre eles, que estendem na terra o corpo em toda a sua extensão, visto já não necessitarem de pés, os deuses os fizeram sem esse segmento, permitindo que rastejassem no solo. O quarto gênero, que vive na água, provém dos mais estúpidos e ignorantes de todos. As divindades que os metamorfosearam não os consideram dignos nem mesmo de respirar o ar puro, por terem as almas contaminadas por toda sorte de faltas; em lugar de deixá-los respirar um ar leve e puro, afundaram-nos na água, para que só aspirassem a água lodosa da profundidade" (Platão, 2001, 91a-92b). 
fundamental, segundo esse pensamento, situava-se na separação entre vida e nãovida.

Mesmo os estoicos, que desenvolveram o conceito de instinto ou impulso (hormé) até o ponto em que os homens se separariam dos animais por um princípio distinto de ação - racional, para os humanos, instintivo, para os bichos , não obstante compreendiam o instinto como um "análogo psíquico da inteligência, embora um análogo mais compacto, mais concreto, menos consciente, mais fechado" (Simondon, 2004, p. 74). Nas palavras do filósofo Gilbert Simondon, há uma diferença chave entre o automatismo proposto pelos estoicos e o de Descartes: o dos antigos é um "automatismo instintivo, psíquico", enquanto o segundo é puramente "físico", "mecânico"78. Isto é, ainda que quase toda a história da filosofia, até ali, procurasse estabelecer, encontrar ou inventar o limite entre humanos e animais, não é senão com Descartes que se realiza a separação que Lévi-Strauss tão bem descreveu como fundante do humanismo,

${ }^{78}$ É importante notar que embora houvesse uma continuidade de vida, isto é, que tudo o que é vivo fizesse parte de um contínuo, para os estoicos e que o seu automatismo fosse de ordem psíquica, o seu princípio (arkhé, initium) de justiça estava fundado na oikeiôsis, que no caso humano só se estenderia aos seres racionais, isto é, aos outros homens e aos deuses. Aos animais é concedido que estendam a oikeiôsis à sua prole. Tal exclusão dos animais significa que é possível fazer com eles o que se bem entenda sem que isso constitua uma injustiça ou maldade. Tem-se, portanto, uma elaborada teoria que exime os humanos da responsabilidade pelo que quer que venham a fazer com os animais, isto é, que retira os animais dos problemas éticos. Esse ponto é valioso para nós, pois discutiremos, em seguida, se a tese cartesiana das bestas-máquinas autorizou práticas consideradas cruéis contra os animais. Para uma discussão aprofundada acerca do pensamento estoico no que concerne aos animais, cf. Sorabji, 1993, especialmente o capítulo 10, "Oikeiôsis and bonding between rational beings." Ainda segundo Sorabji, havia uma vertente do estoicismo que recomendava a abstinência do consumo de carne, mas por motivos ascéticos que não diziam respeito aos animais: "Apesar de os estoicos terem nos inundado com manuais sobre todos os tipos de questões de ética prática [...], até onde eu saiba, eles não dedicaram nenhum à necessidade de tratar bem os animais. De fato, é difícil ver como alguém poderia ter uma atitude benevolente dirigida aos animais se, como Crisipo, visse os porcos como tendo uma alma apenas como conservante culinário" (Sorabji, 1993, p. 125) - o autor refere-se a essa passagem de Porfírio: "Mas, claro, é convincente aquele dito de Crisipo, segundo o qual os deuses nos fizeram para eles e para manter relações mútuas e os animais para nós, isto é, os cavalos para nos ajudar na guerra, os leopardos, ursos e leões para que sirvam de exercício a nosso valor. E quanto ao porco [...] não nasceu senão para ser sacrificado e a divindade mesclou a alma à sua carne, como se se tratasse de sal, trazendo-nos um bom prato de fiambre" (Porfirio, 1984, 3.20, p. 165-166). Na versão em espanhol do De Abstinentia, o tradutor adverte que "não se trata da alma em sentido racional, mas da faculdade de não-putrefação da carne" (idem, nota 82, p. 166). Ele também faz referência ao segundo livro do De Natura Deorum, de Cícero, no qual se lê: "Quanto ao porco, o que tem além de alimento? Ao qual certamente, para não entrar em putrefação, Crisipo diz ter sido dada uma alma exatamente como o sal; e do que esse animal, porque era apropriado para servir de alimento aos homens, a natureza não criou nada mais fecundo" (Vendemiatti, 2003, 2.160, p. 104). A problematização das almas animais segundo os estoicos requereria um estudo por si, o que não farei aqui; vale notar, no entanto, que essas almas, embora possam significar, como no caso do porco, apenas que sua carne não apodrece, podem variar dependendo da espécie. Isto é, ainda que os animais sejam viventes de segunda ordem por não participarem da oikeiôsis humana e da justiça, há uma alma diferente para cada espécie animal. 
aquela que vai "cortar o homem da natureza e constituí-lo como um reino soberano", supondo - ou tendo a intenção de - "apagar desse modo seu caráter mais irrecusável, qual seja, [que] ele é primeiro um ser vivo" (Lévi-Strauss, 2013, p. 53). Pois foi precisamente apagando esse "caráter irrecusável" e "concedendo a uma [à humanidade] tudo o que tirava da outra [da animalidade]" (idem), que Descartes fundou sua filosofia.

Agora, no lugar de uma prodigalidade de almas de vários tipos bem distribuídas no mundo, concebe-se apenas uma divisão, a saber, entre a substância pensante ou res cogitans e a substância extensa ou res extensa, a primeira compartilhada por seres humanos e celestiais e a segunda configurando os corpos, cujas relações e movimentos podem ser explicados de um modo puramente mecânico. Já no Traité de l'homme, obra publicada postumamente em 1664, mas cuja origem remonta aos anos 1630, conforme indicação do próprio Descartes em carta a Mersenne ${ }^{79}$, o filósofo afirmava que "o corpo não é outra coisa que uma estátua ou máquina de terra, que Deus forma expressamente para torná-lo o mais parecido conosco quanto possível" (Descartes, 2004, p. 807). A analogia com as máquinas vem em seguida - se "relógios, fontes artificiais, moinhos (idem)" feitos por mãos humanas se movem por si mesmos, o que dizer das máquinas produzidas por Deus? Ora, após quase setenta páginas de uma extensa descrição mecanicista e ilustrada do corpo, finalmente é dito de uma só vez aquilo de que elas são capazes quando, no último parágrafo do tratado, Descartes conclui:

Eu gostaria que vocês considerassem, depois disso, que todas as funções que atribuí a esta máquina, como a digestão de carnes, o batimento do coração e das artérias, a nutrição e o crescimento dos membros, a respiração, a vigília e o sono; a recepção da luz, dos sons, dos odores, dos gostos, do calor e de tais outras qualidades nos órgãos dos sentidos exteriores; a impressão de suas ideias nos órgãos do sentido comum e da imaginação, a retenção ou o empréstimo dessas ideias na memória; os movimentos interiores dos apetites e das paixões; e enfim os movimentos exteriores de todos os membros que seguem a este propósito tanto as ações dos objetos que se apresentam aos sentidos quanto as paixões e as impressões que se encontram na memória, que imitam o mais perfeitamente quanto é possível aqueles de um verdadeiro homem: eu desejo, digo, que vocês considerem que essas funções se seguem todas naturalmente, nesta máquina, apenas da disposição de seus órgãos, nem mais nem menos do que fazem os movimentos de um relógio, ou outro autômato, seus contrapés e suas rodas; de modo que não é preciso quanto a ela conceber nenhuma alma vegetativa nem sensitiva, e nenhum outro princípio de movimento e de vida além de seu sangue e

${ }^{79}$ Em uma carta de 23/11/1646, coligida por Bridoux na apresentação do Traité, Descartes afirma que “... há já 12 ou 13 anos que descrevi todas as funções do corpo humano, ou do animal [...]" (Descartes apud Bridoux, 2004, p. 805). 
seus espíritos ${ }^{80}$, agitados pelo calor do fogo que arde continuamente em seu coração e que não é de outra natureza que todos os fogos que estão nos corpos inanimados (Descartes, 2004, p. 873).

\section{O Tratado do homem, assim como o $O$ mundo ou Tratado da luz apela para} o registro da ficção em sua construção: Descartes cria um mundo, no mais das vezes idêntico àquele em que ele mesmo vive, para descrever seu funcionamento. E se, neste caso, o texto começa deixando claro seu caráter de hipótese, presente já na frase de abertura - "esses homens serão compostos, como nós, de uma Alma e de um Corpo" (idem, p. 807, grifo meu) -, assim o é porque só no caso de uma outra espécie de homens seria possível imaginar seu corpo e sua alma separados, tal como o Tratado os toma. No caso dos bichos, entretanto, tal "fábula" é a rigorosa descrição de seus corpos desanimados. Procede-se assim, conforme observa a filósofa Elizabeth de Fontenay, a uma "separação quase cirúrgica entre o que é alma, a substância espiritual, e o que é extensão, a substância material” (de Fontenay, 1998, p. 377). Mas enquanto falar em homem-máquina só é possível sob a forma mítica, as bestas-máquinas populam o nosso mundo real.

O penúltimo parágrafo do Tratado enuncia uma regra geral, um princípio que Descartes supõe seguir: "que a natureza age sempre segundo os meios que são os mais fáceis de todos e os mais simples" (Descartes, 2004, p. 873). Desse modo, se se pode explicar o movimento dos animais sem recorrer a uma alma, é assim que se deve fazê-lo ${ }^{81}$. E, como para o filósofo não há nada de que o corpo não seja

${ }^{80}$ Não confundir esses "espíritos" com algum tipo de alma: trata-se do que na quinta parte do Discurso do Método é chamado de "espíritos animais", "um desses fogos sem luz" (Descartes, 1973, p. 63), que excita os corpos em seu coração, "um vento muito sutil [..] que, subindo continuamente em grande abundância do coração ao cérebro, dirige-se daí, pelos nervos, para os músculos e imprime movimento a todos os membros; sem que seja preciso imaginar outra causa [...] segundo as regras da Mecânica, que são as mesmas da natureza" (idem, p. 67).

81 Este mesmo princípio é ainda amplamente difundido em práticas científicas que pretendem estudar o comportamento dos animais; Konrad Lorenz, um dos pais da etologia, por exemplo, afirma em seu Os fundamentos da etologia, de 1981, não apenas que "qualquer animal é completamente capaz, por meio de comportamento variável orientado a um objetivo, de se esforçar para alcançar uma finalidade, mas que esta finalidade, ao contrário do que supuseram os psicólogos finalistas, pode não ser a mesma que a execução da função teleonômica do comportamento. A finalidade que o animal, como sujeito, está se esforçando por alcançar é simplesmente uma descarga daquele tipo de comportamento inato que [...] agora chamamos de ato consumatório redutor do acionamento" (Lorenz, 1995, p. 22), mas, prescindindo de uma alma imortal e da referência a Deus, sustenta, de um modo que talvez agradasse a Descartes, que "já que cada passo importante na evolução cria características sistemáticas não precedentes", a diferença entre humanos e animais é "de essência, não de grau" (idem, p. 432, grifo meu) e que, portanto, "Não é exagero afirmar que o pensamento conceitual - acompanhado pela linguagem sintática - é um novo tipo de vida" (idem, p. 434). Lorenz diverge de si mesmo em suas práticas de pesquisa, que serão mencionadas em outra seção, e é possível que a linguagem usada por ele em seu livro fosse assim dura com o objetivo de estabelecer a etologia como ciência. 
mecanicamente capaz além de pensar, o que está intimamente ligado a falar com sentido, e como o filósofo jamais observou uma besta se comunicando com seus companheiros, ainda que algumas possuíssem os órgãos necessários para isso ${ }^{82}$, fica provado que elas não têm alma.

O terrível corolário desta tese é que os animais, não tendo alma de qualquer ordem, não pensam e portanto não sentem dor (ou prazer etc.). De acordo com as respostas às Sextas objeções, há três tipos de sensação: as físicas, mero resultado de estímulos diretos aos órgãos; as conscientes (percepções) e as autoconscientes (juízos). Em um artigo chamado "Animais, homens e sensações”, a filósofa Ethel Rocha explica que:

O primeiro grau de sensação seria, portanto, puramente mecânico, não constituindo em sensação propriamente dita, mas sim apenas no movimento de partícula dos órgãos e na mudança de forma e posição que resulta desse movimento. Esse grau de sensação Descartes admite ser comum a todo animal, seja humano ou não. O segundo, na medida em que se trata de uma percepção, envolveria consciência e seria resultante do fato de que a mente está de tal modo intimamente unida ao corpo que é afetada pelos movimentos que ocorrem nele; e o terceiro seria pensamento puro e consistiria no juízo que fazemos, resultante do fato de sermos afetados por uma sensação e dependente apenas do intelecto (Rocha, 2004, p. 354).

${ }^{82} \mathrm{Um}$ dos animais mais presentes nos textos de Descartes como exemplo daqueles que possuem os órgãos necessários mas são incapazes de falar é, naturalmente, o papagaio. Não posso deixar de me referir a uma observação da filósofa e treinadora Vicki Hearne, citada por Vinciane Despret: "os filósofos humanos tendem a falar de maneira estranha quando surge o tópico dos papagaios, como se eles acreditassem que seu estatuto dependesse do estatuto diminuído dos papagaios [...]. Porque o problema dos papagaios é que eles precisam controlar as trocas. Você quer travar uma conversa, uma conversa que rapidamente toma a aparência de um teste de QI e você se encontra desencaminhado por um hábito comum de todos os papagaios falantes: sua recusa de deixar que outro indivíduo escolha o assunto da conversa. Você chega para um papagaio, e provavelmente ele está em uma gaiola e você não, então você se sente bem superior, talvez você até pense que pode sentir pena do papagaio, e você pergunta ao papagaio como ele está e ele diz algo gnômico como 'é o seu avô' ou 'quão belas e roxas são as andorinhas do fim do verão'. Então o papagaio olha para você de um modo realmente interessado e expectante para ver se você vai jogar a bola de volta. Você começa a tentar descobrir o que o papagaio quis dizer com aquilo, e é isso. Você não tem a menor chance de reintroduzir qualquer assunto que tinha em mente. É por isso que os filósofos seguem negando que os papagaios podem falar, claro, porque um filósofo realmente gosta de ter o controle da conversa" (Hearne apud Despret, 2008, p. 124). Para um amplo e inovador estudo sobre as capacidades cognitivas, especificamente do papagaio-cinzento (Psittacus erithacus), cf. The Alex Studies: Cognitive and Communicative Abilities of Grey Parrots, de Irene Pepperberg, especialmente o capítulo "Can a parrot learn referential use of English speech?" Para além dos experimentos em que Alex mostrou-se capaz de entender conceitos como o da permanência de um objeto, o de igual e o de diferente, o papagaio chegou a desenvolver um conceito parecido com o de zero ("Ele então seria perguntado 'O que é diferente?' ou 'O que é igual?'. A resposta correta seria 'nenhum' [none] ou a indicação da categoria apropriada, não a cor, forma ou marcador material específico que representava a resposta correta (ex. 'cor' e não 'amarelo'). Para estar correto, Alex teria, como antes, que (1) atentar para múltiplos aspectos dos diferentes objetos; (2) determinar, a partir de uma pergunta vocal, se a resposta deveria se basear em 'igualdade' e 'diferença'; (3) determinar, ao olhar para os itens, qual, se algum, era 'igual' ou 'diferente' (ex. eram ambos azuis, triangulares ou feitos de madeira?) e então (4) produzir, vocalmente, a marca da categoria apropriada ou a resposta 'nenhum'" (Pepperberg, 2002, p. 85). A porcentagem de acerto de Alex ficou entre 88.9 e 92\%. 
As expressões dos animais, sejam elas gestos ou sons, não são senão meros reflexos. Em carta a Mersenne de 11 de junho de 1640, Descartes diz ao amigo que

Eu não explico sem a alma o sentimento da dor; pois, de acordo comigo, a dor não está senão no entendimento; mas explico todos os movimentos exteriores que acompanham em nós esses sentimento, os quais são os únicos que se encontram nas bestas, e não a dor propriamente dita (AT, III, p. 85).

\subsection{2.}

\section{Bestial com as bestas}

John Cottingham, célebre comentador de Descartes, escreveu em 1978 um artigo hoje famoso, "A brute to the brutes? Descartes' treatment of animals", no qual constrói uma defesa do filósofo contra a "tese monstruosa" (Cottingham, 1978, p. 551) de que os bichos não sentem nada, baseada sobretudo em uma suposta confusão da parte de Descartes em relação às suas próprias ideias sobre sensações, com Cottingham concluindo que "a verdade talvez seja que Descartes nunca tenha estado completamente à vontade com o dualismo estrito, por mais que o afirmasse enfaticamente" e que "no fim das contas, Descartes talvez não fosse completamente consistente, mas pelo menos não foi de todo bestial com as bestas" (idem, p. 559, grifo meu).

Sua argumentação apoia-se principalmente em duas passagens. A primeira é uma carta a Newcastle, na qual o filósofo diz que "todas as coisas que ensinamos [qu'on fait faire] cachorros, cavalos e macacos a fazer não são senão os movimentos de seu medo, de sua esperança ou de sua alegria, de modo que eles o podem fazer sem nenhum pensamento" (Descartes apud Cottingham, 1978, p. 557), o que o comentador interpreta como uma evidência do atrapalhamento de Descartes, pois que tais sensações não poderiam se realizar sem pensamento. Sua segunda evidência é colhida no artigo 190 do livro IV dos Princípios, e mostra Descartes produzindo o que Cottingham considera uma quimera, o termo "alegria animal" (laetitia animalis), diferente da "alegria intelectual" (gaudium intellectuale). Para ele, tal expressão, alegria animal, demonstraria mais uma vez que o filósofo teria considerado a possibilidade de uma sensação tendo lugar apenas no corpo. Cottingham constrói então seu caso sugerindo que Descartes vacilava e se embaralhava acerca de suas próprias ideias. A dificuldade, 
entretanto, se ouso dizer, jaz menos na clareza de Descartes do que na crença confusa do próprio Cottingham de que a alegria é um "inescapável predicado mental" (idem, p. 559). É claro que o termo "alegria animal” não quer dizer "a alegria que sentem os animais", mas uma alegria cujo lugar é o corpo físico; e de que serve o corpo físico desatrelado de uma alma que lhe permita ter consciência daquilo que sente? O problema todo é que os impulsos animais de sede e fome, por exemplo, não estão ligados a uma ideia, mesmo que confusa, como é o caso nos homens, não sendo, portanto, sensações em sentido próprio, mas apenas aquelas do primeiro tipo, meramente mecânicas. É o mesmo caso com essa tal alegria, que é descrita em termos corporais, pela ação de "pequenos nervos", assim como outras paixões tais como a tristeza, a raiva, etc.

Rocha comenta essa passagem frisando a importância da "atitude proposicional" para a teoria das sensações de Descartes, recuperando uma resposta deste a uma objeção de Hobbes: "é evidente que ver um leão e ao mesmo tempo ter medo dele é diferente de simplesmente vê-lo. E ver um homem correr é diferente de afirmar em silêncio para si mesmo que se vê" (Descartes apud Rocha, p. 360). Ter sensações propriamente ditas, para Descartes, significa ser consciente delas. As bestas-máquinas, pura res extensa, não têm consciência e, assim, não podem ter sensações. É como se, para sofrer, fosse necessário um pensamento conceitual sobre a dor - ou, pelo menos, a atitude "compreendo que sinto dor agora e isso é verdade", coisa de que as bestas seriam incapazes.

Além de omitir, em sua interpretação, as respostas às Sextas objeções nas quais os três tipos de sensação são explicados, Cottingham esquece de mencionar a carta a Mersenne em que o filósofo afirma expressamente que os animais não sentem dor ("não explico sem a alma o sentimento da dor..."). O comentador parece preferir declarar que Descartes "se atrapalhou", com o intuito talvez de criar uma "dúvida razoável" de modo a não comprometê-lo com o que considera uma tese "bestial", escolhendo cuidadosamente algumas passagens em detrimento de outras, além de simplesmente negligenciar o envolvimento do filósofo com certas práticas científicas, como por exemplo a vivissecção.

Mas é Pierre Bayle quem leva a tese de Descartes a seu limite. Autor dos artigos que melhor mapeiam a querela das almas animais no século XVII, "Pereira" e "Rorarius", em seu Dicionário histórico e crítico, Bayle não se furtou 
a expor o caráter monstruoso da tese das bestas-máquinas. Já em 1684, nas

\section{Nouvelles de la république des lettres, ele escrevia:}

do lado de M. Descartes [há] um sentimento [...] que choca tão rudemente a luz natural de tantas pessoas, que se diz em alto e bom som em mil lugares que é uma vergonha para a França \& para o nosso Século ter produzido um Filósofo que pôde ter pronunciado com sucesso a monstruosa opinião que as bestas são máquinas (Bayle, 1684, p. 24).

No artigo "Rorarius", Bayle escrutina não apenas a tese cartesiana como as objeções levantadas pelos escolásticos, em uma série de notas extensas e inspiradas que parecem não deixar pedra sobre pedra no castelo das doutrinas sobre as almas animais ${ }^{83}$. No que diz respeito às bestas-máquinas, dois argumentos parecem os mais fortes: o primeiro, que revela a dimensão éticoreligiosa da tese, que proporcionaria grandes vantagens para o cristianismo embora fosse absurda, e o segundo, que mostra o aspecto verdadeiramente monstruoso do cogito. Na nota $\mathrm{C}$, Bayle explica como

todas as provas do pecado original retiradas da doença e morte, às quais as criancinhas estão submetidas, colapsam assim que se supõe que os animais têm sensações. Eles estão sujeitos tanto à dor quanto à morte. Eles, entretanto, nunca pecaram [...] Se as bestas tivessem uma alma cognoscente, "segue-se (1) que Deus não se ama, (2) que ele não é constante, (3) que ele é cruel e injusto." Ele não amaria a si pois teria criado "almas capazes de conhecimento e amor sem obrigálas a amá-lo e conhecê-lo." [...] De acordo com a opinião comum, as almas das bestas retornam para o nada no instante em que as bestas cessam de viver. Onde então está a constância de Deus? Ele cria almas e logo as destrói, mas não faz a mesma coisa no que diz respeito à matéria, pois nunca a aniquila. Portanto, Deus conserva as substâncias menos perfeitas e destrói a mais perfeita. Isso é coisa de um agente sábio? A alma das bestas não pecou, e ainda assim está sujeita à dor e à miséria. Está sujeita a todos os desejos irregulares de criaturas que pecaram. Como tratamos as bestas? Fazemo-las se despedaçarem umas às outras para o nosso prazer. Matamo-las para nos nutrir. Dissecamos suas entranhas enquanto ainda estão vivas para satisfazer nossa curiosidade, e fazemos tudo isso como resultado do domínio que Deus nos deu sobre as bestas. A quanta desordem a criatura inocente é assujeitada pela criatura criminosa! Nenhum casuísta acredita que alguém peca ao fazer touros lutarem contra cães, e assim por diante, e ao empregar milhares de artimanhas e meios violentos para destruir animais na caça, pesca e afins, ou por se divertir matando moscas, como o fazia Domiciano. Ora, não é cruel e injusto submeter uma alma inocente a tantos males? Livramo-nos de todas essas dificuldades pelo dogma de Descartes (...) (Bayle, 1730, Nota C, p. 87).

83 À primeira vista, o único a sair ileso é Leibniz, com quem Bayle trava uma longa conversa. Montaigne, no entanto, é um caso curioso, pois seu nome aparece em uma das notas sem, inusitadamente, nenhuma objeção às suas ideias. No verbete "Pereira", porém, é consenso que, quando Bayle diz que "as opiniões sobre esse assunto [a alma das bestas] são ou absurdas ou muito perigosas", (Bayle, 1730, tome 3, p. 652), o perigo seria uma referência a Montaigne, para quem "há mais diferença de tal homem a tal homem que de tal animal a tal homem" (Montaigne, 1965 , p. 368) 
É verdade que um sentimento parecido com o de Bayle é expresso pelo próprio Descartes em uma carta a More: "Deste modo, minha opinião não é tanto cruel com os animais quanto indulgente com os seres humanos, já que os absolve da suspeita de crime quando comem ou matam animais" (AT, V, p. 278-279). O que é possível ser entrevisto aí é o fundamento político da doutrina cartesiana. Os homens torturam e matam os animais e é preciso livrá-los da suspeição de crime; seres que nunca pecaram sofrem, o que não é condizente com o cristianismo, e é preciso justificar a fé. O mundo está no lugar.

Mas há ainda um outro problema, que diz respeito aos próprios semelhantes humanos. E é a razão ela mesma que, segundo Bayle, mostra como tal tese é insustentável: pois, ao tomar o cogito como fundamento em um mundo no qual "a natureza age sempre segundo os meios que são os mais fáceis de todos e os mais simples" e onde é possível que haja autômatos perfeitos, o fato de que haja outros seres com alma fora de mim é algo sem nenhuma evidência e que só é possível afirmar por analogia (e, se por analogia, por que não estender a cortesia às bestas?). Pergunta, assim, Bayle, na nota G:

onde está o homem que ousaria dizer que é o único que pensa e que todos os outros são máquinas? Não seria ele visto como um personagem mais extravagante que aqueles que são colocados em asilos de lunáticos ou mantidos distantes de toda a sociedade humana? Essa consequência da teoria cartesiana é um irritante estragaprazeres. Ela se parece com os pés de um pavão; é uma feiúra que mortifica a vaidade que a brilhância de sua plumagem havia inspirado (Bayle, 1730, p. 87).

Se o automatismo das bestas é vantajoso para a religião, como foi demonstrado por Bayle, poder-se-ia pensar o mesmo no que diz respeito às ciências; pois, já que os animais não sentem nada, está permitida toda sorte de experimento invasivo que se queira fazer. Descartes mesmo, de quem se conta que apreciava vivissecções sobretudo de peixes e coelhos, contou em carta ter "observado, em cães abertos completamente vivos, que seus intestinos têm um movimento regrado quase como aquele da respiração" (Descartes, 2004, p. 1082). Certamente, entretanto, não foi ele quem instituiu a prática de vivissecção de animais a sangue frio, já praticada por William Harvey, por exemplo, e cuja origem remonta pelo menos ao romano Galeno. 
Vesalius, considerado o pai da anatomia moderna, advogava, no século XVI, a vivisseção como método de aprendizagem nas escolas ${ }^{84}$, muito mais eficaz, segundo ele, que a mera leitura de livros (cf. O’Malley, 1964; Hart, Wood e Hart, 2008). Em sua obra De humani corporis fabrica, ele chega a apresentar a bizarra ilustração de um porco em agonia acorrentado e sendo aberto por querubins. Cadelas grávidas, como a de Malebranche, também eram usadas de modo que se pudesse observar os filhotes ainda não nascidos, conforme contou Baldasar Heseler em Primeira anatomia pública de Andreas Vesalius em Bolonha, 1540: relato de uma testemunha.

O historiador David Wooton conta, fazendo referência ao capítulo VII do De fabrica, que Vesalius “sabia perfeitamente que a vivissecção era uma forma de tortura (a cadela é cruciata, crucificada ou torturada)" (Wooton, 2007, p. 99). Wooton menciona ainda o testemunho de dois cientistas do século XVII, Robert Hooke e Nicolas Steno, que poderiam estar plenamente conciliados com suas práticas e livres da suspeita de crime, mediante a benção da filosofia de Descartes; a quem bastaria dizer que, conforme mostrava o filósofo francês, nossos animais não sentem nada. $\mathrm{O}$ intrigante é que essas pessoas, que faziam experimentos cotidianamente com animais, isto é, que estavam em sua companhia grande parte do tempo (e a quem deviam grande parte de seus sucessos intelectuais), produziam um discurso bem diverso ao se comunicarem entre si: Hooke escreveu a Boyle em 1664:

O outro Experimento (que dificilmente, confesso, farei de novo, pois foi cruel) foi com um cachorro, o qual, por meio de um par de foles com os quais enchi seus

84 Método aliás usado até hoje, ainda que com anestesia. Segundo uma pesquisa encomendada pela National Anti-vivisection Society em 2014, por exemplo, 84\% dos professores de ciências de nível pré-universitário afirmaram praticar vivissecção em sala de aula nos EUA (http://www.navs.org/education/dissection-in-the-classroom). Para um estudo sobre o uso de animais no Brasil, inclusive no Ensino Médio, além de suas alternativas, cf. Bones, 2012. A autora explica que "animais de laboratório são utilizados em diversas áreas, como pesquisa, produção de medicamentos, testes de cosméticos e outros produtos, diagnóstico de doenças, assim como no ensino. Por mais que existam inúmeras alternativas disponíveis para substituir o uso de animais no ensino, a prática ainda é comum em diversos cursos de ensino superior, porém ainda não existem informações acuradas sobre o número de animais usados pois o controle oficial brasileiro [...] encontra-se em construção. As únicas informações disponíveis são provenientes de estudos estimando o número de animais usados em pesquisa [..]. Neste sentido, Silla e colaboradores [...] investigaram o uso de animais por meio do método de amostragem bibliográfica a partir de periódicos científicos publicados no estado do Paraná em 2006; os resultados mostram um total conservador de 3.497 .653 animais usados, sendo que 216.223 foram vertebrados. De forma semelhante, Taylor e colaboradores (2008), com base em artigos científicos publicados internacionalmente, estimaram que foi usado 1,16 milhão de animais vertebrados no Brasil em 2005. Estes números certamente são subestimados" (Bones, 2012, p. 9). 
pulmões e os esvaziei de novo, consegui preservar vivo por quanto tempo eu desejasse, depois de que abri totalmente o tórax e cortei fora todas as costelas e abri a barriga [...] Meu desígnio era fazer algumas investigações a respeito da natureza da respiração. Mas [...] dificilmente serei induzido a fazer novas tentativas desse tipo, por causa da tortura da criatura; mas certamente a investigação seria nobre se pudéssemos encontrar um modo de estupefazer a criatura, para que não esteja sensivel (Hooke apud Shannon ${ }^{85}$, 2001, p. 260, grifo meu).

Steno, em carta de 1661 a seu mestre Thomas Bartholin, confessou que "não é sem repugnância que os torturo com uma dor tão prolongada”, completando que "os cartesianos se orgulham muito da verdade de seu sistema filosófico, mas gostaria que me convencessem do fato de que animais não têm alma!" (Steno apud Guerrini, 1989, p. 406). Nenhum desses cientistas abandonou a prática da vivissecção, porém - Hooke foi inclusive persuadido, três anos depois, a realizar mais uma vez o experimento de tórax aberto com o cão. Isto é, ainda que conhecessem a doutrina de Descartes e pudessem fazer uso dela para se isentarem do risco de estar sendo cruéis, parte dos cientistas não apelou a ela.

Em um artigo de 1989, a historiadora da ciência Anita Guerrini mapeou a prática de vivissecção no século XVII, sobretudo na Royal Society. Segundo ela, a maioria dos adeptos compreendia que os animais sentiam dor, alguns lhes atribuindo mesmo consciência - ainda que não racionalidade. Essa crença, porém, não os impedia de seguir com as experimentações, que se sustentavam na tese cristã da "administração" (stewardship) ${ }^{86}$ da Criação pelo homem. Boyle, que

85 A historiadora Lisa Jardine ressalta a comparação desta carta, um registro pessoal, com o frio relatório oficial da experiência: "Um Cão foi dissecado e, por meio de um par de foles e um tipo de Tubo empurrado pela Traqueia da Criatura, o coração continuou a bater por muito tempo depois de todo o Tórax... ter sido aberto" (Jardine apud Shannon, p. 260, n.96). É interessante observar a assepsia do discurso científico, de onde as questões de ordem política, pessoal etc. são retiradas. Sobre a divisão natureza/política, ver Shapin e Schaffer (1985) e Latour (1994).

86 A disputa em torno do lugar do homem em relação à criação, qual seja, a de guardião ou mestre, costuma recorrer ao Gênesis 1, 28, quando Deus diz ao homem e à mulher, que acabara de criar à sua imagem e semelhança: "Deus os bendisse, dizendo-lhes: frutificai, multiplicai, enchei a terra e a dominai. Submetei os peixes do mar, os pássaros e todos os animais da terra.” O que está em jogo aí é a interpretação desses dois verbos, dominar e submeter. Segundo o teólogo Sebastian Doane, trata-se de dois verbos hebraicos, kabash e radah. O primeiro, que diz respeito à terra, segundo ele é "empregado 14 vezes na Bíblia. Encontramo-lo em um contexto de violência ou de luta como meio de conquista da terra prometida". Ele também "descreve a responsabilidade do rei diante das nações que domina." O segundo, radah, que tem mais 21 recorrências na Bíblia, surge sempre em contextos estritamente humanos, sobretudo na relação do rei com seus súditos. Para Doane, conquistar a terra diz respeito a trabalhá-la para que se possa "viver pacificamente nela"; ele argumenta ainda que os deveres do rei para com seus súditos, conforme a Bíblia, são de "serviço e respeito aos outros" e que a o termo "submeter" não é uma boa tradução, apontando que há "certos biblistas ingleses" que propõem a palavra "administrador" (steward, intendant) como solução. A explicação de Doane encontra-se em http://www.interbible.org/interBible/source/lampe/2008/lampe_081024.html. 
conduziu muitos experimentos em animais, ainda que reconhecesse seu sofrimento, os justificava sob o argumento de que "o resto das criaturas foi feito para o homem, já que apenas ele no mundo visível é capaz de gozar, usar e saborear muitas das outras criaturas e discernir a onisciência, onipotência e bondade de seu autor nelas" (Boyle apud Guerrini, 1989, p. 396).

De acordo com Guerrini, ao menos dentro dos círculos dos filósofos naturais ingleses, a doutrina das bestas-máquinas de Descartes, quando abordada, o era mais para ser criticada do que usada para justificar seus métodos. Guerrini argumenta ainda que pode ter sido o outro lado da doutrina que realmente influenciou os círculos científicos de então: a "fábula" do homem-máquina, que levou a uma febre de experimentos, em sua maioria transfusões de sangue animal em seres humanos. De todo modo, o mecanicismo vigente, segundo ela, tanto nos círculos ingleses como nos continentais, não era o do tipo besta-máquina. $\mathrm{E}$, se houve quem criticasse William Harvey nas bases de que o corpo humano era único e os animais não poderiam prover um bom modelo comparativo, a analogia mecanicista entre organismos e máquinas teve como consequência um antropomorfismo perverso por não se assumir como tal. Dualistas até os dias de hoje, consideramos os corpos animais bons substitutos para corpos humanos, mas não ousamos comparar nossas almas senão com muito cuidado, correndo o risco da irônica acusação de antropomorfização.

Não foi preciso transformar os animais em máquinas, privá-los mesmo das mais simples experiências sensoriais, como a dor, para que se praticasse - e se continue praticando - contra eles toda sorte de abuso; é impossível aqui não lembrar da famosa assertiva de Bentham sobre se os animais podem sofrer apenas para percebê-la inútil diante da crença na própria superioridade, que pode ser justificada de diferentes maneiras, e a ideia, familiar a essa crença, de que não se tem nenhuma responsabilidade - no sentido de habilidade de responder - frente a ninguém. Leibniz, por exemplo, que dotava os animais de almas indestrutíveis e criticou diversas vezes a doutrina cartesiana como se afastando demasiadamente do bom senso, foi, ao menos em sua juventude, um entusiasta dos experimentos de Boyle, mostrando um profundo fascínio pela vivissecção; e, embora zombasse das bestas-máquinas cartesianas, exortava seus companheiros nas Directiones de 1671, a "conduzir inúmeros estudos anatômicos nos animais, vivos ou mortos" (Leibniz apud Smith, 2011, p. 49). 


\subsection{3.}

\section{Cauda (de rato)}

Mesmo que não tenha sido o modelo mecanicista apropriado pelos filósofos naturais, talvez seja possível compreender o lugar das bestas-máquinas como um lugar ideal, um norte civilizacional; elas não estariam no começo da história, portanto, mas viriam a ser assim produzidas. Essa história, para atingir seu cume, precisou de condições materiais de possibilidade que não foram alcançadas senão no século XX; ela passa então pela chamada Revolução verde do pós-Segunda Guerra, com a intensificação da produção e a aproximação de animais a plantas pelo uso de técnicas similares, que negligenciam a sua capacidade/necessidade de locomoção, confinando-os a espaços cada vez mais exíguos. Passa também pela seleção artificial com vistas apenas à máxima produção, o que cria povos inteiros cujos corpos, a caminho de se tornar mas não ainda totalmente puras máquinas, carregam um sofrimento contínuo - não é sem razão que o livro de Ruth Harrison publicado em 1964, que constitui o marco da exposição da realidade do tratamento oferecido aos animais na produção industrial, chame-se Animal Machines: the new factory farming industry. Talvez essa história esteja culminando agora, com o advento da chamada carne artificial, um processo que permite a produção de carne fora do indivíduo ou que, em outros termos, consegue finalmente produzir bestas-máquinas, animais sem pés nem cabeça, sem consciência, que não sentem dor, isto é, que realizam o sonho cartesiano. É como se reconhecêssemos um fracasso tamanho no modo de lidar com outros sujeitos que nos fosse mais fácil transformá-los materialmente em objetos que cultivar afetos e relações intersubjetivas com eles. Ou, nas palavras de Donna Haraway, "Músculos-sem-animais geneticamente construídos ilustram exatamente o que Sarah Franklin quer dizer com 'designer ethics', que visa contornar uma luta/problema cultural com um avanço de 'alta tecnologia' na hora certa" (Haraway, 2008, p. 268).

Nesse sentido, melhor que dizer que antropomorfizamos os corpos animais, talvez seja compreender o processo de mecanomorfose que o pensamento e as práticas humanas sofrem. Construímos nosso mundo sobre fundamentos mecanicistas que, nas palavras de Plumwood, "negam à natureza qualquer tipo de agência própria. Uma vez que a esfera não-humana é pensada como não 
possuindo agência, considera-se apropriado que o colonizador humano imponha seus próprios desígnios" (Plumwood, 2003, p. 109). O mundo, em suma, passa a ter apenas um sentido - e que Plumwood diga "colonizador" nos dá uma pista sobre a humanidade que devemos ter em vista. Não se trata, absolutamente, de negar a possibilidade de relações instrumentais entre os seres, que é inclusive uma das formas da cooperação; o problema está em que essa instrumentalização, sendo mecânica, "resulta, em última instância, em uma redução dramática de corpos de fato a práticas biotecnológicas" (cf. Warkentin, p. 86, 2006). E, como bem argumenta Vinciane Despret, essas não são questões morais, mas epistemológicas. Em um artigo sobre o problema do viés em experimentos com animais, ela conclui:

'Desapaixonar' o conhecimento não nos dá um mundo mais objetivo, apenas nos dá um mundo 'sem nós'; e, consequentemente, 'sem eles' - os limites são traçados rápido demais. Enquanto esse mundo aparece como um mundo 'com o qual não nos importamos', ele também se torna um mundo empobrecido, um mundo de mentes sem corpos, de corpos sem mentes, corpos sem coração, expectativas, interesses, um mundo de autômatos entusiásticos observando criaturas estranhas e mudas; em outras palavras, um mundo pobremente articulado (e pobremente articulador) (Despret, 2004b, 131).

É por esse caminho que a figura do ciborgue de Donna Haraway mostra-se revolucionária, contra-mecanomórfica, na medida em que desafia os dois termos presentes na divisão natureza/cultura (ou corpo/alma). A natureza de que o ciborgue faz parte pensa, produz e é produzida, e aquilo que nele é máquina pode fazer parte de um agenciamento que produza subjetividades. Mas, antes de tudo, o ciborgue é híbrido: seu corpo "não é inocente; ele não nasceu num Paraíso; ele não busca uma identidade unitária, não produzindo, assim, dualismos antagônicos sem fim (ou até que o mundo tenha fim) [...] Um é muito pouco, dois é apenas uma possibilidade" (Haraway, 2000, p. 96). O ciborgue escapa de uma visão ingênua sobre as práticas científicas ao mesmo tempo em que promove a subversão da não menos ingênua (ainda que mortífera) crença na mecanomorfose.

Do século XVII até agora, as máquinas podiam ser animadas - era possível atribuir-lhes almas fantasmas para fazê-las falar ou movimentar-se ou para explicar seu desenvolvimento ordenado e suas capacidades mentais. Ou os organismos podiam ser mecanizados - reduzidos ao corpo compreendido como recurso da mente. Essas relações máquina/organismo são obsoletas, desnecessárias. Para nós, na imaginação e na prática, as máquinas podem ser dispositivos protéticos, componentes íntimos, amigáveis eus (Haraway, 2000, p. 96). 
Mas isso não é tudo. O que Descartes, com seu mundo habitado por autômatos, parece pretender, como fica dito na carta a More e como já dissemos, é livrar o homem da suspeição de crime. Um pensamento bem parecido habitava as justificativas da experimentação - o homem, como administrador da criação, pode escolher tratar os animais como bem entende. Aqui caberiam os mesmos argumentos levantados no Capítulo 2 diante da discussão com os proponentes de uma ética inocente, o argumento de Derrida sobre a lógica do sacrifício (cf. Derrida, 2002) e o de Haraway a respeito do mandamento "não matarás" tornando-se "não tornarás matável" (cf. Haraway, 2008). Se cada modo de alguém viver, como dizia a filósofa, implica um modo diferente de outrem morrer, isto é, se não há inocência possível, o mínimo que podemos fazer é estar à altura do sofrimento imposto àqueles que vivem e morrem conosco, mas sempre entendendo profundamente que, por mais que o justifiquemos, nada vai nos redimir.

Tomemos o exemplo de um ciborgue particular, OncoRato ${ }^{\mathrm{TM}}{ }^{87}$, o primeiro animal patenteado, um rato criado em Harvard, bicho geneticamente modificado para possuir um "oncogene", isto é, uma espécie fruto da biotecnociência destinada a desenvolver tumores cancerígenos e, portanto, tornar-se uma boa substituta do corpo humano nas pesquisas científicas sobre o câncer.

O OncoRato ${ }^{\mathrm{TM}}$ é meu irmão e, melhor dizendo, macho ou fêmea, ele/a é minha irmã [...]. Embora sua promessa seja decididamente secular, ele/a é uma figura no sentido desenvolvido dentro do realismo cristão: ele/a é nosso bode expiatório; ele/a carrega o nosso sofrimento; ele/a significa e representa nossa mortalidade de uma maneira poderosa, historicamente específica, que promete um tipo culturalmente privilegiado de salvação secular - uma "cura para o câncer". Concorde eu ou não com sua existência e seu uso, ele/a sofre, fisicamente, repetidamente, e profundamente, para que eu e minhas irmãs possamos viver. No modo de vida experimental, ele/a é o experimento [...]. Se não em meu próprio corpo, certamente nos corpos de minhas amigas, eu terei um dia uma grande dívida com o/a OncoRato ${ }^{\mathrm{TM}}$ ou com seus parentes subsequentemente engendrados. Então, quem é ele/a? (Haraway, 2011, p. 37).

Criar e matar OncoRato ${ }^{\mathrm{TM}}$, para Haraway, pode ser justificado de muitas maneiras - quem negaria a importância de pesquisas que podem aliviar o sofrimento do câncer? -, mas apenas por razões mundanas, isto é, aquele tipo de razão que pode trazer coisas boas para o mundo ao mesmo tempo que faz maldades. O que não

${ }^{87}$ Embora a patente tenha expirado em 2005, o nome OncoMouse ${ }^{\mathrm{TM}}$ ainda é uma marca registrada de propriedade da DuPont. 
temos disponível como justificativa são "a majestade da Razão e o consolo do Sacrifício" (idem).

Ainda sobre roedores, a médica veterinária Vanessa Carli Bones, em estudo sobre o uso de camundongos em testes de inoculação para o diagnóstico da raiva, amplamente em vigor no Brasil mesmo havendo alternativas ao uso de animais e legislação que criminaliza "quem realiza experiência dolorosa ou cruel em animal vivo, ainda que para fins didáticos ou científicos, quando existirem recursos alternativos" (Brasil, 1998), calculou que

em um laboratório que realiza 200 MITs [mouse inoculation tests] por mês e inoculam oito camundongos por amostra, o número de animais usados ficaria em torno de 19.200 por ano. A estimativa não inclui animais que devem ser substituídos depois de mortes não-específicas por causa do trauma acarretado pela injeção intracerebral ou por infecções secundárias que podem se seguir à inoculação (Bones, 2014, p. 50).

No caso do diagnóstico da raiva, o cultivo celular é um método substitutivo eficaz porém pouco difundido. Em outras práticas didáticas ou científicas envolvendo animais, há ainda a possibilidade do uso de

modelos animais feitos de plástico [...], materiais audiovisuais, programas de computador, métodos bioquímicos e imunológicos de análises e testes em organismos menores [como embriões] substituindo o uso de mamíferos (idem, p. 29).

A pesquisa de Bones envolveu um questionário aplicado a pessoas que trabalham com o diagnóstico da raiva no qual revelou-se que $50 \%$ dos respondentes brasileiros usavam camundongos, contra $20 \%$ dos que responderam em inglês. No Brasil, ainda, especificamente na Universidade Federal do Paraná, um outro questionário mostrou que "apenas $38.9 \%$ dos professores e $31.9 \%$ dos estudantes acreditavam na utilidade" (idem, p. 30) dos métodos alternativos. A autora concluiu, com base nessas e outras perguntas, que:

As principais barreiras que impedem a utilização de métodos alternativos para o diagnóstico da raiva apontadas por respondentes em português foram: falta de recursos humanos e capacitação profissional; acomodação, hábito e falta de boa vontade das pessoas; falta de recursos financeiros; barreiras regulatórias e falta de incentivo do governo; barreiras cultural e ética; falta de estrutura dos laboratórios, equipamentos e materiais; falta de conhecimento e conscientização; importância dos fatores orgânicos para observação da doença; baixa sensibilidade ou falhas das técnicas in vitro; facilidade e baixo preço do IVC [isolamento viral em camundongos]; bem como falta de tempo (idem, p. 29).

Uma tal coleção de causas é curiosa na medida em que elas se entrelaçam e revelam um certo tipo de sociedade, na qual a incapacidade de responder, ou seja, 
a irresponsabilidade diante dos animais em todos os níveis informa um ciclo aparentemente sem saída: faltam recursos materiais e humanos, falta capacitação, falta interesse.

Sobre o discurso das pessoas envolvidas em pesquisas com cobaias animais, a socióloga Iana Maria Almeida de Souza reproduz, no artigo "Vidas experimentais: humanos e roedores no laboratório", o depoimento de uma mestranda que lhe disse estar "desmistificando" o uso de camundongos na pesquisa animada pela crença de que o conhecimento, por sua parte, do que causa dor nos animais, permite que ela lhes dê um tipo de boa morte:

Você faz o experimento com 20 animais - usei, não vou usar mais para nada, aí sacrifico. Faz o deslocamento cervical, então, você segura o rabinho, puxa a cabeça, aí interrompe a ligação com o bulbo, que é onde fica o centro da respiração, aí ele morre rapidinho [...] Eu tenho assim simpatia pelo vegetarianismo, não matar animais p'ra comer [...], então, sabe, eu ainda não digeri por completo esse fato de ter que sacrificar animais, né, são 20, 30, 15 ratos, camundongos, e aí o que eu penso, e me dá uma certa força, é pensar que tem um objetivo maior, que vai salvar algumas vidas ou ajudar, né, no conforto de algumas pessoas no futuro, mas é uma coisa que me incomoda (idem, p. 257).

O que transparece em seu discurso é a fé na ciência como um conjunto de práticas cujos resultados são capazes de aliviar o sofrimento dos outros; é em seu nome que a estudante pode justificar a matança de camundongos. Essa não é uma crença falsa, não se trata disso; é possível e até provável que o sofrimento desses camundongos resulte em algum benefício para humanos, ou para alguns humanos, aqueles que têm acesso aos avanços da biotecnomedicina. Mas é importante também não permitir que a questão se transforme em uma alternativa infernal: ou os camundongos ou nós. Ou: é necessário que eles sejam torturados para que nós possamos viver. A estudante se diz incomodada com as mortes, mas que espécie de saída ela pode encontrar em instituições que não creem em métodos substitutivos, em um mundo que não considera essas mortes como tais? O grande desafio, nesse caso, é como transformar as práticas de laboratório cosmopoliticamente, acolhendo e favorecendo processos transformadores que envolvam humanos e animais. E, no limite, também, como sugere Haraway, que

[...] tornemo-nos melhores em morrer em vez de matar. Às vezes uma "cura" para o que quer que nos mate simplesmente não é razão suficiente para manter as máquinas de matar funcionando na escala em que nós (quem?) nos acostumamos (Haraway, 2008, p. 81-82). 
A vontade de inocência e a hybris da dominação do mundo também se exprimem em um desejo de imortalidade. Aprender a morrer, portanto, em vez de apenas matar.

Souza conta ainda o que lhe disse uma cientista que durante muitos anos trabalhou em biotério mas que, à altura da entrevista, apenas coordenava projetos que tinham lugar ali:

Atualmente eu não vou mais ao biotério e não manuseio animais, meus estudantes cuidam desse trabalho. Mas lembro que quando minha filha nasceu, eu trabalhava em uma pesquisa em que era necessário sacrificar muitos animais. À noite quando voltava para casa e via minha filhinha dormindo, parecia que eu estava vendo um camundongo, eu tentava afastar essa visão, mas a imagem do camundongo sempre voltava (Souza, 2013, p. 242).

A cientista não pensa em termos de inocência e morte mas é arrastada, em sua relação com a filha, para uma zona de indiscernibilidade entre humanos e animais, e precisa, por causa de seu trabalho, recusar o devir. O bebê torna-se camundongo e o camundongo torna-se o quê? Torna-se, ou continua em sua gaveta no biotério, sendo manipulado, inoculado, morto e descartado? Os camundongos não apenas reagem, eles respondem, existem e insistem, mesmo à noite, durante o cândido sono de uma criancinha. O que significará responder a eles? Que mudança cósmica operar-se-ia aí? Repitamos Deleuze e Guattari: "A agonia de um rato", diziam eles, permanece "no pensamento, não por piedade, mas como a zona de troca entre o homem e o animal" (Deleuze e Guattari, 2009, p. 142). E ainda: “o devir é sempre duplo, e é este duplo devir que constitui o povo por vir e a nova terra" (idem). Que nova terra, que povo por vir se delineiam nos sonhos que a cientista recusa? Que mundos constituiriam a visão que ela tenta afastar?

Essas perguntas ou desafios não têm respostas teóricas; elas precisam ser experimentadas na carne que forma cada ator situadamente envolvido. O que podemos sugerir, apenas, é que cultivar a habilidade de responder, interessar-se pelo mundo, sair dos dualismos, em suma, abandonar o pedestal que construímos por medo de sermos criminosos significa compreender que, diante do olhar de OncoRato ${ }^{\mathrm{TM}}$ e seus parentes, não há razão suficiente. 


\subsection{4. Kluger Hans}

Köhler, o psicólogo que desenvolveu os experimentos a que Sultão foi submetido, não foi o primeiro nome cogitado para dirigir a estação de antropoides em Tenerife. Ele só chegou lá um ano depois do estabelecimento da estação, em 1913, para substituir Eugene Teuber. Esses dois primeiros diretores, entretanto, apesar do sucesso do trabalho que ali realizaram, possuíam pouca experiência em psicologia animal e somente foram convidados a ocupar o cargo depois de o filósofo e psicólogo Carl Stumpf, um dos responsáveis por essa indicação, ter recebido a recusa de um de seus mais brilhantes pupilos, o biólogo e psicólogo Oskar Pfungst. Àquela altura, Pfungst era o mais famoso praticante de psicologia comparada, por causa de sua pesquisa com o cavalo Hans Esperto alguns anos antes em Berlim, ao final da qual o cientista concluiu que o animal - e por conseguinte, todos os animais, até que se provasse o contrário - não possuía habilidades de raciocínio, criticando mesmo Sokolowsky e suas ideias de que haveria uma vida anímica dos grandes primatas. Foi nesse "clima de divisão e desconfiança” (Ruiz e Sanches, 2014, p. 6) que Köhler preparou-se para investigar uma possível inteligência dos chimpanzés em Tenerife.

Despret dedicou um profundo estudo ao caso de Hans e Pfungst que resultou em um livro, Hans, le cheval qui savait compter (2004) e pelo menos um artigo, "The Body We Care For: Figures of Anthropo-zoo-genesis" (2004). Ela conta que, em 1904, Hans, com então 4 anos, causava espécie em Berlim como um animal inteligente, capaz de responder a perguntas de aritmética e mesmo de geografia; às questões que lhe eram colocadas, Hans batia um determinado número de vezes com um dos cascos no chão e quase sempre acertava o resultado. Diante desse mistério e da possibilidade de sua inteligência estar fundada em algum truque ou engano hábil desenvolvido por seu dono, von Osten, um grupo de especialistas, entre eles Stumpf, reuniu-se para observar a cena e o cavalo. Estupefatos, o grupo de sábios formado por um professor, um veterinário, o diretor de um zoológico, um aristocrata, um militar aposentado e um empresário de circo, entre outros, concluiu que não havia nenhum ardil: Hans era mesmo esperto e podia responder às perguntas longe da presença de seu dono-treinador. Um cavalo genial, alguns pensaram. Mas Pfungst, que era então assistente de 
Stumpf, o líder da comissão, não aceitou essa possibilidade e pôs-se a conduzir sua própria investigação, obstinado em compreender o que realmente se passava entre Hans e seus questionadores.

O nível de sucesso do cavalo era impressionante, mas Pfungst não se abateu por isso, insistentemente procurando os sinais que Hans decerto estaria seguindo para responder bem ao que lhe era perguntado. Finalmente, depois de muitas horas de pesquisa, surgiu uma hipótese: talvez esses sinais não fossem intencionais, talvez houvesse um engano de que os envolvidos humanos não estivessem a par:

O sr. von Osten pede a Hans que repita um número para outro cavalheiro e sai do pátio [onde Hans se apresentava]. Aquele outro cavalheiro, que não tinha ouvido o número escolhido, entra e pede a Hans que o repita. Hans falha. Se o interrogador não sabe a resposta, o cavalo não consegue encontrá-la. Há sinais, então. Pfungst agora pode começar a procurá-las. E conseguirá. Por horas e horas, ele observa, experimenta, testa diferentes hipóteses: o que acontece se Hans não puder ouvir a pergunta? O cavalo ainda conta. O que acontece se ele não puder ver o rosto do interrogador? Hans ainda conta. O que acontece se Hans não puder ver o corpo de seu interrogador? Ele falha. O corpo está envolvido: Hans pode ler corpos humanos (Despret, 2004b, p. 113).

O que Pfungst descobre, então, é que Hans é capaz de ler os micromovimentos não intencionais que seus interrogadores realizam, e é por isso que é tão bem sucedido. Ninguém estava em conluio com o cavalo, mas ele possuía uma habilidade desconhecida por seus interlocutores; e mais: o jogo a que de boa vontade se entregava significava para ele uma outra coisa que para seus colegas humanos. Enquanto os últimos criam estar testando habilidades matemáticas (razoáveis) do animal, ele se engajava em uma troca de leitura corporal (uma habilidade perceptiva) e os satisfazia: "cada um deles, exceto o cavalo, era ignorante deste surpreendente fenômeno: seus corpos falavam e se moviam contra a sua vontade, fora do enquadre de sua consciência” (idem).

Mas o que se passava ali era ainda mais complexo: Hans, sem que seus questionadores percebessem, os treinava para que eles lhe dessem os micromovimentos certos, aqueles que lhe permitiam responder corretamente. Pfungst observou que a maioria dos movimentos que as pessoas faziam na ausência do cavalo poderiam ser considerados expressões naturais, mas um deles, o que significava "zero", diferia em sua presença. Isto é, Hans lhes havia ensinado, os havia treinado e influenciado para the dessem o sinal de que ele precisava. Além disso, o percentual de sucesso do cavalo aumentava com alguns 
interrogadores em especial, os quais, Pfungst notou, iam se tornando melhores em movimentar-se inconscientemente para ele. O que acontecia entre o cavalo e seus interrogadores, diante dessa novidade, era espantoso, pois significava não haver predominância de subjetividade, não haver objeto estudado e sujeito estudioso: "Hans os fez se mover de outro modo, mudou os hábitos de seus corpos e os fez falar uma outra linguagem. Ele os ensinou como serem afetados diferentemente de modo a afetar diferentemente" (idem, p. 116). Se um cavalo de corrida e um cavalo de trabalho diferem naquilo de que são capazes, a história de Hans demonstra o que um cavalo experimental, envolvido em um jogo, uma brincadeira - é importante notar que Hans envolvia-se, interessava-se pela relação - pode. Não se trata mais apenas do que pode um corpo, mas de como corpos que se afetam tornam-se capazes uns para e com os outros. Ambos, Hans e seus questionadores, performavam uma dança, influenciando-se uns aos outros, e saíam dela modificados. Ele, como um cavalo esperto para os humanos; elas, como humanos espertos para cavalos. Que cada um, aparente ou conscientemente, estivesse respondendo a perguntas diferentes não muda o fato de que algo se passava de um ao outro, conformando todos como outros para si e para os outros.

Mas, nota Despret, nenhuma dessas incríveis capacidades entraram para a história como tal e o caso de Hans viria a se tornar um conto moral, aquele sobre perigo da influência em pesquisas científicas. Em primeiro lugar, como notou Pfungst, Hans não possuía inteligência no sentido em que esta é uma expressão da razão, mas "apenas" habilidades perceptivas. Depois, passou a se tornar imperioso evitar que estudiosos e estudantes confundissem seus lugares, influenciando-se uns aos outros; era preciso evitar o devir que, como veremos, para Despret, é sempre um devir-com. Em suma, era preciso que os lugares de sujeito e objeto mantivessem-se absolutamente demarcados, evitando zonas de influência ou indiscernibilidade, para que se fizesse boa ciência, objetiva e desinteressada - ou, nas palavras de Haraway, para que o cientista ocupasse o lugar de Deus. Isto resultou em bizarros dispositivos de pesquisa nos quais os investigadores deveriam passar o mínimo de tempo com seus objetos, de modo a evitar que relações se formassem, ou em um ideal de dispositivo inteiramente não-humano, como, por exemplo, o uso de braços mecânicos e que tais.

Despret, entretanto, recupera o caso de Hans Esperto com outra intenção, qual seja, a de reabilitar as possibilidades transformativas e produtoras de mundo 
que podem surgir nas relações humano-animais, inclusive as de pesquisa. É isso que ela chama de antropo-zoo-gênese, o processo pelo qual animais e humanos constituem-se uns aos outros em devir-com, uma transformação do conceito deleuzo-guattariano que se dá entre pelo menos dois que não devêm um o outro, mas um com o outro; por exemplo, não se devém-cavalo, mas com-cavalo, um cavalo particular, não necessariamente singular ou anômalo, que, por sua vez, devém-com humano. Mesmo que Deleuze e Guattari afirmem que o devir-animal ocorre entre dois, o termo que se devém muitas vezes pode ser abstrato ou determinado pelo primeiro; por exemplo, no devir-baleia de Ahab, "é preciso que o animal, Moby Dick, torne-se pura brancura insustentável, pura muralha branca resplandecente, puro fio de prata que se estende e se torna flexível 'como' uma moça, ou se retorce como um chicote, ou ergue-se como um parapeito"; uma pintura de pássaro "é um devir-pássaro que só pode acontecer à medida que o próprio pássaro esteja em vias de devir outra coisa, pura linha e pura cor" (Deleuze e Guattari, 2005, p. 106). Isto é, ainda que digam "ao mesmo tempo", o devir não é descrito como "um devir-brancura de Moby Dick ao mesmo tempo que um devir-baleia de Ahab", ou "um devir-cor do pássaro ao mesmo tempo que um devir-pássaro do pintor", com os termos invertidos, o devir do pássaro ou de Moby Dick precipitando o devir no pintor e em Ahab. Ademais, Moby Dick pelo menos não é um animal "deste mundo"; o pássaro pode ser, assim como o cavalo que o pequeno Hans, o menino atendido por Freud por cujo caso os autores se interessam, vê na rua, e que provoca nele um devir-cavalo. Mas esse pássaro visto pelo pintor ou o cavalo que sofre um acidente, esses animais particulares, o que se passou com eles? Não há nenhuma evidência de que aquele pássaro ou aquele cavalo tenham experimentado um devir; no caso do cavalo acidentado, aliás, é muito provável que ele tenha apenas morrido. Há exceções no repertório dos devires que os autores elencam, como o caso da vespa e da orquídea: a vespa devém orquídea, mas a orquídea por sua vez devém vespa - isto é, ambas devêm juntas. ${ }^{88}$ Mas há também o momento exemplar no qual eles defendem, com Lawrence, que o animal pode não ser real se o devir o é:

\footnotetext{
${ }^{88}$ Para uma interpretação desse devir que articula o conceito de Deleuze e Guattari com as ciências naturais, cf. o artigo "Involutionary Momentum: Affective Ecologies and the Sciences of Plant/Insect Encounters", no qual Carla Hustak e Natasha Meyers tratam o encontro como um fenômeno intra-ativo e um bloco de devir, oferecendo uma "leitura que amplifica os relatos das práticas criativas, improvisacionais e fugazes através das quais plantas e insetos se envolvem nas
} 
Para Lawrence, o devir-tartaruga no qual ele entra não tem nada a ver com uma relação sentimental e doméstica. [...] Mas, justamente, recrimina-se a Lawrence: "Suas tartarugas não são reais!" E ele responde: é possível, mas meu devir o é, meu devir é real, inclusive e sobretudo se vocês não podem julgá-lo, porque vocês são cachorrinhos domésticos... (idem, p. 26; grifo meu).

Além disso, o animal com o qual se entra em devir deve ser "um indivíduo excepcional", ser o "anômalo" do bando (idem, p. 25), não podendo jamais se confundir com um "indivíduo preferido, doméstico e psicanalítico" (idem, p. 26). Devir e devir-com são, portanto, dois conceitos que se aplicam a situações distintas. Quando Despret, por sua vez, fala em devir-com, ela quer dizer com isso que há pelo menos dois "deste mundo" envolvidos: um etólogo e um ganso, uma senhora e um cão, um criador e uma vaca, que devém um com o outro - o etólogo ou a senhora não se tornam ganso ou cão, mas se tornam com, isto é, conjuntamente e à medida em que o ganso ou cão tornam-se com eles. A senhora torna-se com-cão-com-senhora, o cão, com-senhora-com-cão, e assim sucessivamente. Trata-se, além disso, de quaisquer dois, sem a necessidade da excepcionalidade. Haraway, a quem este conceito é caro, fala no processo de devir-com como de mundificação; isto é, não se trata de um termo tornar-se o outro, mas de ambos, juntos, criarem mundos (cf. Haraway, 2008).

A ciência, assim, não teria por objetivo descobrir o mundo ou descrever a realidade tal como ela é, pois mundo e realidade seriam sempre processos, mas criar e produzir realidades e mundos - mundos concretos que envolvem a articulação de corpos. Afastar-se do objeto estudado, impedindo que este se interesse, tem por consequência que ele se torne desinteressante também, criando um mundo pobre, frio e desabitado - "sem eles" mas também "sem nós”, na medida em que o pesquisador barra seus fluxos relacionais e idealiza uma nãoperspectiva. Por outro lado, permitir-se entrar em relação com o objeto, agora tornado sujeito, é a promessa de um mundo mais rico no sentido de que ele se torna mais articulado e permite que estudiosos e estudados tornem-se juntos, devenham uns com os outros.

A autora nos dá um outro exemplo, o caso dos ratos de Rosenthal. Em 1966, o professor de psicologia pediu a seus estudantes que fizessem uma série de experimentos com duas estirpes de ratos, informando-lhes que uma linhagem era

vidas uns dos outros" (Hustak e Meyers, 2002, p. 77). Sob esta perspectiva, o devir da vespa e da orquídea pode ser considerado também um devir-com. 
composta por ratos inteligentes (vindos de Berkeley) e outra por ratos burros, que teriam se tornado assim por serem de grupos resultantes de um longo processo de reprodução. Os estudantes, tendo estudado os ratos como lhes havia pedido o mestre, concluíram sem surpresa que os inteligentes se saíam muito melhor que os burros, confirmando que pertenciam a classes distintas, como lhes havia dito seu professor - mas o ardil do mestre estava em que todos os ratos eram na verdade iguais e ordinários, vindos do mesmo criadouro. A lição, então, não dizia respeito aos ratos, mas a como estudantes com ideias pré-concebidas podiam influenciar seus objetos de pesquisa, o que provava que deviam perseguir a neutralidade. Despret discorda da conclusão tirada pelo autor do experimento e propõe uma outra, que seja capaz de conferir peso à realidade, ao contrário das interpretações tipo subjetividade versus objetividade, nas quais ou bem os termos se opõem e é preciso buscar a única realidade, objetiva, do mundo, ou há apenas subjetividades e nenhuma objetividade, o que leva a um esvaziamento ontológico. Se o mundo ou a realidade são da ordem do processo e da produção conjunta, ela diz, então é possível compreender aquilo que se passou entre Rosenthal, os estudantes e os ratos como um jogo de influências múltiplas alcançadas por uma rede de autorizações criando uma "realidade real." Isto é, aquilo que o experimento demonstra é que um professor pode (ou não) autorizar seus estudantes a serem bons estudantes; que os ratos podem (ou não) autorizá-los a tornarem-se bons cientistas; que os estudantes podem (ou não) autorizar os ratos a serem bons sujeitos - e não objetos - de pesquisa, de modo que um mundo ricamente articulado emerja dessas autorizações, que só podem surgir pelo interesse mútuo. $\mathrm{O}$ resultado do experimento mostra que mundo e realidade estão sempre sendo produzidos e dependem de como os entes se autorizam ou são permitidos se autorizar em cada situação, a depender de sua disponibilidade e interesse uns diante dos outros. Os termos envolvidos no processo experimental devem portanto ser interessados para que se tornem interessantes, encontrando-se em uma zona de inter-esse, uns em busca dos outros, tornando-se juntos uns com os outros. Caso isso aconteça, a consequência será o surgimento de ratos-com-cientistas, cientistas-com-ratos, professor-com-cientistas-com-ratos e assim por diante, em um movimento que devolve peso ontológico à realidade produzida - na medida em que todos os atores nela envolvidos passam por um processo e terminam de 
modo diferente do que começaram -, além de se constituir como uma epistemologia mais de acordo e à altura dessa realidade.

Para que o interesse possa surgir e levar os elementos a um devir-com, é preciso que o dispositivo de pesquisa seja interessante para os sujeitos pesquisados. Ou seja, é necessário que aos animais sejam feitas "boas perguntas", perguntas que os engajem nos experimentos propostos a eles; mas, mais que isso, explica Despret, é preciso saber distinguir interesse de docilidade, ou seja, dar ao sujeito pesquisado a possibilidade de resistir ao experimento ${ }^{89}$. Hans Esperto pôde tornar-se com seus humanos por meio de uma teia de autorizações e interesses que lhe permitiu influenciá-los e responder a eles. Sultão, o chimpanzé de Köhler, por outro lado, não tinha outra possibilidade a não ser realizar aquilo que se esperava dele - o dispositivo transformou seu corpo em um corpo dócil, incapaz de resistir, seja por fome, seja porque não havia saída do terreiro que não fosse a realização da única coisa que se esperava dele.

Despret lembra ainda dos macacos rhesus que formaram o conjunto que o psicólogo Harry Frederick Harlow submeteu, nos anos 1950 e 1960, a experimentos destinados a testar os efeitos do rompimento de laços afetivos entre filhotes e suas mães. Em seus experimentos, bebês de macacos rhesus eram separados das mães e mantidos em ambientes diversos, cada um com menos objetos que o outro; por exemplo, um bebê poderia ser mantido em uma gaiola mínima com uma "mãe substituta", que consistia em uma armação de arame forrada com uma superfície felpuda; outro, apenas com a armação de metal. Havia ainda aqueles que o cientista submetia ao "poço do desespero", uma cápsula de isolamento total na qual um animal poderia passar um ano inteiro, desde o seu nascimento, sem nenhum estímulo ou contato e na total escuridão. Esse tipo de experimento, que Despret chama corretamente de tortura - coisa que o próprio

\footnotetext{
${ }^{89}$ A ideia de resistência ou recalcitrância é haurida por Despret da série Cosmopolitiques, de Isabelle Stengers, bem como do artigo "Des sujets récalcitrants" de Latour, no qual ele glosa a obra de Stengers: "O melhor modo de imitar as ciências naturais é se dar sujeitos recalcitrantes, capazes, justamente, como os objetos da ciências exatas, de recusar as exigências do pesquisador e lhe impor novas obrigações. Um sociólogo que vai a uma casa para fazer um questionário a uma mãe solteira não produzirá senão ciência repetitiva pois a entrevistada lhe obedecerá passivamente, assinalando as respostas em ordem, obediente à excelência no papel de sujeito sondado. Mas se o mesmo sociólogo interroga uma feminista militante que lhe recusa suas perguntas, lhe coloca outras, inverte o sentido da prova e finalmente o manda embora, então ele poderá fazer ciência! Ele terá esbarrado em um sujeito recalcitrante. Terá exigido respostas, mas será obrigado dali em diante a colocar outras. Tendo corrido um risco, seu discurso poderá se tornar científico" (Latour, 2006, p. 188). O que Despret sugere, por sua vez, é a ideia de um sujeito animal recalcitrante.
} 
Harlow intuía quando nomeava seus dispositivos como "cavalete do estupro", "poço do desespero" ou "dama de ferro", entre outros - destinava-se à produção de corpos dóceis ou objetos sem resistência. Infelizmente, ou felizmente de um ponto de vista histórico, há filmes e fotos desses experimentos disponíveis hoje em abundância, inclusive na internet. $O$ que se vê neles também pode ser desesperador para o espectador: criaturas quebradas, assujeitadas, sozinhas, amarradas, com medo, talvez loucas. $\mathrm{O}$ que esses filhotes podiam fazer a não ser sofrer pacientemente aquilo que o cientista lhes impunha? Havia saída ou resistência possível além do desespero que se ensejava criar neles? Nem mesmo a morte era uma possibilidade. Despret insiste em que um bom aparato é aquele que permite ao sujeito estudado resistir, isto é, transformar as perguntas que lhe são feitas - como foi o caso de Hans Esperto, por exemplo -, em suma, um aparato que não decide de antemão as competências e as possibilidades de um corpo, de um animal, de um sujeito, mas que permite que o interesse e a disponibilidade mútuas venham a ser, criando um processo de devir-com.

Konrad Lorenz, célebre por ter sido um dos fundadores da etologia e pelo seu envolvimento com o partido nazista na Alemanha, realizou alguns dos experimentos que Despret considera interessantes e que, por lidarem com questões sobre maternidade, funcionam como um bom contraponto às torturas de Harlow. Suas pesquisas sobre imprinting - o fenômeno supra-individual que leva os animais, após seu nascimento, a seguirem o primeiro ser que virem em movimento - contam o que se passou depois que o etólogo resolveu ficar por algumas horas com uma pequena fêmea de ganso logo que ela saiu do ovo. Marina, como ele a nomeou, depois de ter passado esse tempo com o cientista, recusou os cuidados do ganso domesticado que cuidaria dela e "dirigiu a Lorenz um 'chamado de abandono"” (idem, p. 129). Ele respondeu ao chamado, passando a se comportar "exatamente como se a tivesse adotado, fingindo ignorar que tinha sido ela a me adotar" (Lorenz apud Despret, 2004b, p. 129). O dispositivo desenvolvido por Lorenz, explica Despret, construiu

as condições práticas que permitiram a cada um deles trazer à existência novas possibilidades, novas disponibilidades: o ganso adquire um comportamento flexível e surpreende Lorenz ao adotá-lo. Lorenz se torna pronto a se tornar uma mãe de ganso e pode assim talvez adicionar a seu repertório científico novas questões sobre imprinting, novas questões sobre vínculos, novos modos de coletar dados, novas competências e novos modos de levar sua prática científica (Despret, 2004b, p. 130). 
De um modo avesso ao de Harlow, Lorenz se faz mãe, vira mãe de ganso ao permitir que Marina o adote e se interesse por ele, disponibilizando-se a ela. Ela, por sua vez, como ganso filho de humano, torna-se disponível para ele. Despret fala em uma "ativação de ponto de vista" (cf. idem, p. 131) por parte do etólogo, que transforma o que poderia ser um objeto - Marina - em sujeito. Ele não se torna ganso nem Marina se torna humana, mas ambos constituem novas subjetividades entrelaçadas ${ }^{90}$ - sujeitos que se co-constituem, tornando-se responsáveis um diante do outro, sujeitos cujas competências não estão previamente dadas, mas podem ser experimentadas, descobertas ou inventadas na diferença específica. Em outras palavras, Lorenz e Marina experimentam, em seu devir-com, uma antropo-zoo-gênese: ele não devém ganso, mas “com-um-gansocom-um-humano" (idem), ao mesmo tempo em que Marina devém com-umhumano-com-um-ganso. Cada um desses processos de subjetivação contém inúmeros processos de dessubjetivação, processos em que os eus vacilam e se transformam por meio de uma "coreografia ontológica", para citar um termo de Haraway (cf. Haraway, 2016a). Uma coreografia que imbrica humanos e animais em naturezasculturas e da qual podem emergir, a cada vez, sujeitos capazes, interessantes, interessados. Sujeitos-outros que formam mundos ricos e fazem ciência, boa ciência.

Quanto a Hans Esperto, conta ainda Despret, embora Pfungst acreditasse ter desvendado seu "truque" e o inserido na história da psicologia como um caso de influência que se deve evitar, restam problemas. No decurso de suas observações, houve momentos em que o cavalo acertou mesmo quando seu interrogador não sabia a resposta (cf. Despret, 2004a, p. 118). De todo modo, depois de ter sido "desmascarado", Hans Esperto deixou de ser interessante para seu dono, von Osten, que o vendeu a um joalheiro chamado Karl Krall. Krall, que jamais acreditou na explicação de Pfungst, continuou a trabalhar com o cavalo, dando-lhe aulas, disponível, interessado e confiante. Dois outros cavalos se juntaram a Hans, "Mohammed e Zarif, que receberam uma educação quase similar à de seu

${ }^{90}$ Despret e sua parceira, a socióloga Jocelyne Porcher, em seu livro Être bête, explicam o devir-com a partir do discurso dos pequenos criadores com quem conversaram e de acordo com o modo pelo qual estes descreveram a relação com seus animais: "Trata-se mais precisamente de viver como seus animais vivem, de transformar o tempo em duração [...] Não se trata de identidades 'idênticas', mas de colocações em relação, de fronteiras e de sua passagem [...] Podese partilhar o mesmo mundo, não um mundo idêntico" (Despret e Porcher, 2007, p. 85). 
companheiro" (idem, p. 134). Juntos, eles voltam a ser sensação, "tornam-se os três 'os famosos cavalos de Elberfeld"' (idem). De modo a provar que Pfungst estava errado, os animais respondiam a perguntas inclusive no escuro, sem poder ler sinais humanos, e acertavam. Seria ingênuo, argumenta Despret, considerar que eles possuíam de fato uma inteligência conceitual e conhecessem aritmética ou gramática (os animais também soletravam); essas são coisas que muito provavelmente interessam somente aos humanos. Mas havia algo que lhes interessava, algo no jogo que praticavam com boa vontade, que escapou ao cientista investido em explicar seu comportamento de um modo puramente mecânico. Hans resistiu à sua mecanomorfose, reinventando-se com Krall e seus colegas e desse modo encontrou uma saída das narrativas mecanicistas e redutoras. Para sua felicidade, conclui a autora, nenhum cientista voltou a investigá-lo: "no fim das contas, sem dúvida foi melhor para ele permanecer aquele a respeito de quem as pessoas se enganaram" (idem).

\subsection{5. \\ Parentesco como política}

Em devir ou devir-com, aquilo a que práticas como a da arte e a da ciência interessada podem convidar é a um modo de existir ou viver com os animais, ou um modo de os animais existirem ou viverem com humanos. Se o mundo, como dizia Despret evocando o filósofo William James, não está pronto, mas em constante feitura (cf. Despret, 2004b), então experiências de entrelaçamento por disponibilidade e afeto são capazes de constituir mundos nos quais grandes divisores como humanidade e animalidade não fazem mais sentido como dualismos, mas nos quais se é atravessado o tempo todo por afetos outros na diferença específica: "Ser um é sempre tornar-se com muitos" (Haraway, 2008, p. 4). O que esses experimentos artísticos e científicos mostram é que já estamos com os animais, já afetamos e somos por eles afetados, e que o mundo é o resultado contingente e provisório desses arranjos. Cada um dos devires ou devires-com, ao se reterritorializarem ou desaguarem em processos antropo-zoogenéticos, engendram uma identidade ainda valente a novas transformações: "identidades comuns emergem e são muito estimadas, mas elas permanecem 
sempre uma teia relacional que se abre a passados, presentes e futuros nãoeuclidianos" (idem, p. 32).

Podemos, claro, e atualmente parecemos especialistas nisso, recusar o jogo e a dança multiespecíficos, criando mundos pobres por valorizarmos aquela "razão do desconhecimento". Por outro lado, e há testemunhos disso na arte e na ciência, podemos nos engajar na "dança enlameada com muitos parceiros emanada das espécies entrelaçadas e nelas" (idem). É uma questão de enlamear também a filosofia, o pensamento e as ações em geral, fincar-lhe os pés no chão e permanecer ali para ver o que acontece: "Trata-se hoje de construir esse 'devircom' com outros seres, não mais sob o modo esgotado das analogias - o modo mesmo que permitiu aos filósofos manter o mundo à distância -, mas sob aquele do respeito e da resposta" (Despret, 2009, p. 750).

E, ainda que Deleuze e Guattari temessem com todas as suas forças as reterritorializações edipianas, há talvez, em uma outra ideia de parentesco, a promessa de emaranhamentos que resultem, não em uma prisão ou na neutralização dos devires, mas em outros passos da coreografia ontológica. Se, para desespero dos seguidores de Descartes, não apenas “jamais fomos humanos”, como diz Haraway, mas, seguindo os biólogos Gilbert, Sapp e Tauber, “nunca fomos indivíduos", "somos todos líquens" (Gilbert, Sapp e Tauber, 201291) e a vida na terra proliferou e evoluiu por infecção e indigestão, então as alianças são a experimentação mais radical e também a mais primordial (cf. Haraway, 2016b, cap. 3):

Parente é uma categoria selvagem que todo tipo de gente se esforça para domesticar. Fazer parentes como parentes-estranhos [oddkin] em vez de, ou pelo menos adicionalmente a, parentes-deus [godkin] e famílias genealógicas e biogenéticas perturbam assuntos importantes, como diante de quem alguém é de fato responsável. Quem vive e quem morre, e como, nesse parentesco em vez daquele? Qual a forma desse parentesco, onde e quem faz suas linhas se conectarem e desconectarem, e daí? O que deve ser cortado e o que deve ser ligado

91 Os autores defendem que, "durante a última década, a análise do ácido nucleico, especialmente o sequenciamento de genoma e técnicas de alto rendimento de RNA [encontraram] interações significantes de animais e plantas com micro-organismos simbióticos que desfazem as fronteiras que até hoje caracterizaram o indivíduo biológico. Animais não podem ser considerados indivíduos segundo critérios anatômicos ou fisiológicos porque uma diversidade de simbiontes estão presentes e funcionais na completação de vias metabólicas e servindo outras funções fisiológicas. De modo similar, esses novos estudos mostraram que o desenvolvimento animal é incompleto sem simbiontes. Simbiontes também constituem um segundo modo de herança genética, provendo variação genética selecionável para a seleção natural. O sistema imunológico se desenvolve, em parte, em diálogo com simbiontes e assim funciona como um mecanismo para integrar micróbios na comunidade animal-célula" (Gilbert et alii, 2012, p. 325). 
se o florescimento multiespecífico na terra, incluindo seres humanos e outros-quehumanos em parentesco, devem ter oportunidade? (idem, p. 2).

Para Haraway, a constituição desses oddkin encontra um lugar privilegiado no grupo de práticas que ela concentra na sigla SF: "science fiction, speculative fabulation, string figures, speculative feminism, science fact, so far [ficção científica, fabulação especulativa, camas-de-gato, feminismo especulativo, fato científico, até aqui]" (idem), algumas das quais, pelo menos, figuraram neste nosso capítulo. Elas não são absolutamente a mesma coisa, mas precisam umas das outras na medida em que imaginação, afeto, discurso e aparatos se informam, co-formam e deformam uns aos outros. Animais podem ser sujeitos ou objetos em cada uma delas, a depender de autorização, interesse e disponibilidade, assim como outros entes do mundo.

Le Guin, no ensaio "Deep in admiration”, propõe estender o parentesco também a todos os próximos - desde animais até rios e pedras - e explica: "acho que estou tentando subjetivar o mundo, porque vejam até onde objetivá-lo nos trouxe. Subjetivar não é necessariamente cooptar, colonizar, explorar. Antes, pode envolver uma grande busca para fora da mente e da imaginação" (Le Guin, 2016, p. 75). Subjetivar o mundo, uma saída à catástrofe, não significa, para a escritora, transformar os outros em nós, mas buscá-los fora - ou dentro, no caso de muitos simbiontes. Essa tarefa não pertence, segundo ela, somente à arte ou à poesia. De modo semelhante a Haraway, Le Guin propõe que, enquanto "a ciência descreve com precisão a partir de fora, a poesia descreve com precisão a partir de dentro. A ciência explica, a poesia implica. Ambas celebram aquilo que descrevem” (idem). Ela conclui seu texto citando um poema do místico cristão Henry Vaughn no qual os versos cantam que as pedras, mesmo sem linguagem, existem em "admiração profunda" diante de ventos e rios. E comenta:

por admiração, eu entendo a reverência pela conectividade infinita, a ordem naturalmente sagrada das coisas, e alegria nisso, e deleite. Para que admitamos as pedras em nossa comunhão sagrada; para que as pedras talvez nos admitam na delas (idem, p. 89).

Reconhecer, produzir e inventar oddkin diante uns dos outros; interessar-se, tornar-se disponível e capaz, autorizar; entrar em fluxos multiespecíficos, imaginativos, conceituais, em discurso e em ação são modos de abrir portas para a criação de mundos em que animais humanos e outros-que-humanos coexistam de um modo intensamente cosmopolítico. Quem sabe, assim, Bruxo, Nausicaa, 
Batatinha, Nikkie, Yeroen, Luit, Mama, as famílias de lobos e os grupos matrilineares babuínos, Pedro Vermelho, Consul, Josefina, Sultão, OncoRato ${ }^{\mathrm{TM}}$, os camundongos de biotério, Hans Esperto, Mohammed, Zarif, os macacos rhesus cobaias e tantos outros sem nome possam nos admitir em sua comunhão.

Então, o que é política? É a arte de criar saídas; é devir-animal e devir-com animais; é fabular diante de e com povos menores; é cultivar uma imaginação simpática, permitindo-se invadir por espíritos e corpos outros, multiespecíficos; é não aspirar à inocência, mas pensar e agir respons-avelmente; é interessar-se pelo mundo, estando aberto e disponível, afetando e sendo afetado pelos outros; é inventar famílias e comunidades monstruosas; é se sujar em admiração. 


\section{5 \\ Desaparecidos}

\section{1. Fins do mundo}

Em 1960, talvez um pouco antes ou um pouco depois da inauguração de Brasília, a cidade que deveria sintetizar a política desenvolvimentista de Juscelino Kubitschek, um grupo de candangos, os trabalhadores da construção civil, imigrantes nordestinos que ainda levantavam a cidade, encontrou, ao terraplanar uma área, alguns ninhos de ratos. Esses ninhos ficavam debaixo da terra, e seus habitantes, bichinhos de pelo alaranjado, com uma listra escura no dorso, focinho longo e cauda grossa, revelaram-se, quando examinados pelo pesquisador João Moojen, pertencer não apenas a uma espécie desconhecida, mas a um novo gênero da família de roedores Cricetidae. Moojen, que recebeu, examinou e descreveu oito desses ratos, homenageou o presidente e seus descobridores ao nomeá-los: Juscelinomys candango, o rato candango de Juscelino (cf. Reis et alii, 2006). A nomenclatura popular dispensou o político e o bicho ficou sendo só ratocandango, como os trabalhadores que o encontraram. Esses homens, que à época da inauguração de Brasília contavam cerca de 40 mil, eram submetidos a jornadas exaustivas de trabalho, racionamento de água, alimentação de péssima qualidade, e viviam em acampamentos precários providos pelas construtoras da "cidade da integração nacional". Em 1959, um ano antes de descobrirem os ratos, os candangos foram vítimas de um massacre, que ficou conhecido como o massacre de Pacheco Fernandes Dantas. Houve uma confusão entre os trabalhadores no refeitório da empresa e a GEB (Guarda Especial de Brasília) foi chamada para contê-los, mas um grupo a enxotou dali para fora. Durante a noite, a polícia retornou. As versões oficiais falam de um a nove mortos, mas a memória subterrânea daqueles que estavam no local narra uma história em que caminhõescaçamba ensanguentados transportaram um grande número de corpos no meio da noite (cf. Carvalho, 1990; Sousa, 2011; Teixeira, 2016). Um jornalista que 
conversou com os sobreviventes conta:

Nenhum dos operários falou em menos de 50 [mortos]. Houve quem estimasse em 120. Mas, para mim, o dado convincente foi o seguinte: apareceram cerca de 93 malas sem dono dentro do acampamento, no dia seguinte. Esse número, 93, é extremamente convincente (Frederico, 2014, s/p).

Diz-se que Brasília foi erguida sobre o sangue dos candangos. Os ratos que são epônimos destes últimos nunca mais foram vistos desde aquela primeira vez, nos canteiros de obra. Foram declarados extintos, a causa sendo a perda de seu habitat: Brasília e o desenvolvimentismo não comportam nenhuma espécie de candango. E, se desenvolvimento é um dos motores do Antropoceno, então o massacre de populações sub-humanas e não-humanas é seu combustível. Dos operários assassinados não se encontraram os corpos; dos ratos, os oito espécimes descritos em 1965 por Moojen encontram-se empalhados no Museu Nacional/UFRJ. Os outros, que compunham todo um povo, jazem anônimos com seus operários sob o solo de nossa capital. São seus fantasmas.

\subsection{1. Homens}

Em 1990, o cineasta Vladimir Carvalho realizou o documentário Conterrâneos velhos de guerra, sobre a história dos candangos em Brasília. Entre muitos depoimentos e imagens acerca das condições de vida e do destino dos operários, a cerca de 1h49min do início do filme, um homem chamado Geraldo, antigo operário da construtora Rabello, conta o que viu. Ele relata ter estado no primeiro cinema dos acampamentos, um lugar improvisado no qual os trabalhadores sentavam-se no chão; dali ouviu os primeiros tiros, quando o filme foi interrompido, e correu até o alojamento da Pacheco Fernandes Dantas, testemunhando o massacre. Ao lhe perguntarem se recordava da fita a que assistiam, Geraldo respondeu que "estava passando o filme daquelas formigas gigantes que não me recordo mais do nome [...] um filme de ficção.” Ele muito provavelmente referia-se a $O$ mundo em perigo (Them!), de 1954, que estreou no Brasil no ano seguinte. Inserida no subgênero da ficção científica conhecido como terror natural, a fita foi uma das primeiras a direcionar sua atenção ao perigo nuclear, além de provavelmente ser a primeira do tipo "insetos gigantes."

Nas décadas anteriores à de 1950 houve obras consideradas como de terror 
natural, como The Hound of the Baskervilles (1921), baseada no encontro de Sherlock Holmes com um suposto cão sobrenatural que o detetive desmascara como apenas um cachorrinho pintado. A fera do mar (The Sea Beast, 1926), uma adaptação de Moby Dick, junto de Monstro marinho (The Sea Bat, 1930), King Kong (1933) e Devil Monster (1936), entre outros, tratam de animais gigantes aterrorizando comunidades humanas. Em White Death (1936), a aventura de um homem contra um tubarão maligno, o personagem do presidente da "Sociedade Wallanga de Protetores de Peixes", que procura dissuadir ou sabotar o herói em nome da vida marinha, é ridicularizado. A ilha das almas selvagens (The Island of Lost Souls, 1932), primeira recriação cinematográfica falada da história do doutor Moreau, de H. G. Wells, sobre o médico que criava híbridos de humanos e animais, endereça os perigos da teoria da evolução e a desmedida de cientistas. $O$ passo do monstro (The Monster Walks, 1932) e Os assassinatos da rua Morgue (Murders in the Rue Morgue, 1932), do mesmo ano, recuperam vagamente o conto de Edgar Allan Poe e a ideia de primatas assassinos, agora participantes de experimentos científicos de transfusões e enxertos, temática que vicejou na década de 1940, com A bela e o monstro (The Monster and the Girl, 1941), Monstro de um mundo perdido (Mighty Joe Young, 1949) e A mulher fera (Captive Wild Woman, 1943), que rendeu duas sequências, A rainha das selvas (Jungle Woman, 1944) e A mulher gorila (The Jungle Captive, 1945). Pongo, o gorila branco (White Pongo, 1945), mostrava um animal terrível encontrado no interior da floresta por aventureiros ocidentais em busca do elo perdido. Na grande maioria dos filmes dessa época, é a evolução que está em jogo, seja na possibilidade de a ciência alterar seu curso natural ou no encontro com feras que, remanescentes de outras eras ou escondidas nas profundezas do planeta, põem a existência da moderna sociedade humana em risco. ${ }^{92}$

A partir principalmente da década de 1950, depois do fim da Segunda

92 Este gênero conheceu uma retomada, com foco ecológico, nos anos 1970: “desde o favorito de Deleuze, Calafrio (Willard, 1971), que dizem ter sido o filme que alavancou a onda, a fitas como A invasão das rãs (Frogs, 1972), Tubarão (Jaws, 1975), Grizzly, a força assassina (Grizzly, 1976), A fúria das feras atomicas (The Food of the Gods, 1976), Orca, a baleia assassina (Orca, de 1977), Animais em fúria (Day of the Animals, 1977) e Um longo fim de semana (Long Weekend, 1978), entre muitas outras. A premissa era sempre mais ou menos a mesma: a humanidade vai longe demais no trato com a natureza - seja por meio de experimentos, os nucleares sendo ainda os favoritos da época, mas também pela objetificação; enfim, pela hybris humana, embora possa acontecer só de alguém ter ido aonde não foi chamado - e sofrer as consequências. É a terra tornada inóspita, contra os homens; a natureza contra a cultura na forma de guerra de destruição" (Fausto, 2016, p. 127). 
Guerra Mundial e da explosão das primeiras bombas atômicas, juntam-se a esses temas a ameaça nuclear e a possibilidade do fim do mundo ${ }^{93}$. Em suas "Teses para a era atômica", o filósofo Günther Anders afirmava que "é errôneo dizer que as armas atômicas existem em nossa situação política", explicando que a questão deveria ser colocada de forma invertida: "Como a situação hoje é determinada e definida exclusivamente pela existência de 'armas atômicas', nós devemos afirmar: ações e desenvolvimentos políticos estão ocorrendo dentro da situação atômica" (Anders, 2013, p. 2-3). Não seria absurdo propor como hipótese que os filmes de ficção científica/terror natural sobre a ameaça nuclear e a radiação, com seus monstros terríveis, formam um modo exploitation de lidar com a nova situação. $\mathrm{O}$ alerta final de $O$ mundo em perigo, no qual formigas mutantes gigantes causam uma devastação, é categórico. Nele, o mirmecólogo Harold Medford, vivido pelo ator Edmund Gwenn, observa: “Quando o homem entrou na era atômica, abriu as portas para um novo mundo. $\mathrm{O}$ que ele porventura encontrará neste novo mundo ninguém pode prever."

Em 1965, a pensadora Susan Sontag escreveu "The Imagination of Disaster", um ensaio sobre os filmes de ficção científica dos anos 1950, procurando articulá-los com o contexto social e político da época. Ela nota, entre outras coisas, que uma característica constante em todos é o perigo (ou já o fato) de a tecnologia atômica, que em princípio poderia ajudar a humanidade a se livrar de alguma ameaça, fugir do controle durante um experimento ou teste malsucedido, ou mesmo estar em vias de causar (ou ter causado) a destruição de algum planeta ou povo (cf. Sontag, 1965, p. 43). Diferentemente da literatura, Sontag observa, é "por meio de imagens e sons, não de palavras a serem traduzidas pela imaginação, que se pode participar da fantasia de viver a própria morte, e mais, a morte de cidades, a destruição da humanidade mesma" (idem, p. 44); em suma, nesse tipo de obra experimentava-se de forma mais imediata e em

93 Ainda que em número reduzido, houve, ainda antes de 1950, fitas que abordavam o fim do mundo: a dinamarquesa Verdens Undergang (1916) e a francesa $O$ fim do mundo (La fin du monde, 1931) utilizaram a passagem do cometa Halley em 1910 para imaginar um outro cometa que causaria destruição em massa; na norte-americana Dilúvio (Deluge, 1933), uma série de desastres naturais, como terremotos e tsunamis, destroem cidades inteiras. Daqui a cem anos (Things to come, 1936), com roteiro de H. G. Wells, encena uma Segunda Guerra Mundial com início em 1939 e duração de quase um século, ao fim da qual uma nova civilização, mais racional, mas ainda plena de tensões, emerge. À exceção de Dilúvio, que abre com uma citação bíblica, os outros filmes endereçam um mal-estar em relação à guerra - a Primeira Guerra Mundial ou o prenúncio da Segunda - que já carregava então a atmosfera social. 
grupo, no cinema, os "pesadelos coletivos" (idem, p. 42) que assombravam aquele mundo. E, segue a autora, se o prazer de ir ao cinema assistir à destruição de cenários elaboradíssimos em filmes de desastre não era novidade, havendo inclusive aqueles sobre temas bíblicos, o que diferencia os filmes de ficção científica da década de 1950 dos outros é que eles não têm mais uma "relação inocente com o desastre" (idem). Neles subjaz

[...] o trauma sofrido por todo mundo no meio do século 20, quando se tornou claro que, dali até o fim da história da humanidade, cada pessoa passaria sua vida individual sob a ameaça não apenas de sua própria morte, o que é certo, mas de algo quase psicologicamente insuportável - a incineração coletiva e a extinção que poderiam vir a qualquer momento, virtualmente sem aviso (idem, p. 48).

Essa observação ecoa aquela de Anders sobre "o tempo do fim versus o fim do tempo" (Anders, 2013, p. 1-2), a época que começa com a explosão das bombas atômicas:

Portanto, por sua natureza mesma, essa era é uma "suspensão", e nosso "modo de ser" nessa era deve ser definido como "ainda não sendo inexistentes", "ainda não exatamente sendo inexistentes". Assim, a questão moral básica de épocas anteriores deve ser reformulada radicalmente: ao invés de perguntar "Como devemos viver", devemos agora perguntar "Iremos viver?". Para nós, que somos "ainda não inexistentes" nessa Era de Suspensão, só há uma resposta: embora a qualquer momento O Tempo do Fim possa se converter n'O Fim do Tempo, devemos fazer tudo a nosso alcance para tornar O Tempo Final infindável. Na medida em que acreditamos na possibilidade d'O Fim do Tempo, nós somos Apocalípticos, mas na medida em que lutamos contra este Apocalipse fabricado pelo homem, nós somos - e isto nunca existiu anteriormente - "Anti-Apocalípticos (idem).

A espécie humana, dizia o filósofo, deixara de ser composta por mortais para se tornar ela mesma mortal (cf. Anders, p. 11 e ss), causando uma mudança em "nosso estatuto metafísico" (idem, p. 12); tal mudança viria a se refletir, no contexto norte-americano do pós-guerra, isto é, dentro do país que primeiro detonou uma bomba atômica e a usou para destruir cidades estrangeiras, através de sua grande máquina de criação de mitos contemporâneos, Hollywood, sob a forma de uma infinidade de filmes de ficção científica. O Japão, alvo das bombas americanas Little Boy e Fat Man ${ }^{94}$, também produziu sua cota de fitas do gênero,

${ }^{94}$ Em The History and Science of the Manhattan Project, o físico Bruce Cameron Reed nota que existe até hoje um debate acerca da origem dos apelidos das bombas, com pelo menos duas versões. Uma delas encontra-se na autobiografia do físico Robert Serber, ex-aluno de Oppenheimer, além de parte da equipe do Projeto Manhattan em Los Alamos, que "alega ter nomeado as bombas, com Thin Man tendo sido tirado do romance de detetive de Dashiell Hammett, de 1934 [também o título de um filme do mesmo ano], e Fat Man referindo-se ao papel do ator Sydney Greenstreet no filme O falcão maltês, de 1941, estrelado por Humphrey Bogart" (Reed, 2014, p. 294-295). Little Boy, ainda, teria surgido mais tarde a partir de Thin Man. Mesmo 
o exemplo mais famoso sendo a série Godzilla, iniciada em 1954 e que apresentava o temível monstro despertado das profundezas do oceano por testes atômicos ${ }^{95}$. A esse respeito, Sontag comenta que

Tem-se a sensação, particularmente nos filmes japoneses, mas não só neles, que existe um trauma imenso em relação ao uso de armas nucleares e à possibilidade de guerras nucleares futuras. A maior parte dos filmes de ficção científica testemunha este trauma e, de um certo modo, tenta exorcizá-lo (Sontag, 1965, p. 46).

Diferentemente dos antigos filmes de terror ou de monstros, naqueles produzidos depois da mudança do "estatuto metafísico" humano a ameaça nunca é local; ainda que muitas vezes o desastre tenha início em uma cidade pequena, é o futuro do planeta ou da espécie que está em jogo. O jornalista Peter Biskind comenta em Seeing is Believing: How Hollywood Taught us to Stop Worrying and Love the Fifties que "a invasão alienígena frequentemente começa no coração do país, uma pequena cidade no meio da América, na América mediana, e se move até as grandes cidades. O socorro, ao contrário, flui do nacional para o local, de D.C. até Podunk ${ }^{96 "}$ (Biskind, 2000, p. 218,5). É esta mesma característica que Sontag critica ao falar na "fantasia da ONU, fantasia da guerra unida" (Sontag, 1965, p. 46), o momento, presente na maioria desses filmes, em que um superEstado ou uma coalizão transnacional emerge heroicamente contra o inimigo planetário. A guerra, assim, e mesmo a guerra nuclear, aparecem como necessárias para a salvação do mundo: "um desastre grande o suficiente", a autora explica, "cancela todas as inimizades e solicita a concentração máxima dos recursos da Terra" (idem). Embora a ciência costume ser a causadora do desastre, é também por meio dela, agora bem administrada, de preferência por um grupo centralizado, que se encontra a salvação; nem a tecnologia atômica, nessas intrigas, está fora do escopo de possibilidades. Como nota Biskind, "em It Came from Beneath the Sea [O monstro do mar revolto] (1955), por exemplo, o polvo gigante em questão é gerado por testes nucleares, mas é também destruído no final por um torpedo

que seja matéria de disputa, a versão sustentada por Serber é amplamente conhecida e mostra a extensão da influência de Hollywood.

${ }^{95}$ A partir de meados dos anos 1960, com Ghidrah, o monstro tricéfalo (San Daikaijū: Chikyū Saidai no Kessen, 1964), Godzilla deixa de ser uma ameaça para se tornar cada vez mais amigável; neste filme, ele começa como inimigo, mas termina a se juntar a dois outros kaiju, monstros gigantes, Mothra e Rodan, para ajudar o governo japonês em sua luta contra Ghidrah, um dragão marciano gigante de três cabeças.

${ }^{96}$ Podunk não é uma cidade real, mas um nome usado para designar uma localidade longínqua e pequena qualquer. Uma tradução adaptada que desse conta do sentido da frase seria algo do tipo "da capital até onde Judas perdeu as botas." 
atômico" (Biskind, 2000, p. 220, 9). Há quem diga, parafraseando o título do filme de Stanley Kubrick de 1964, que esses filmes ensinavam a "parar de se preocupar e amar a bomba". Assistindo a eles, a audiência se reconfortava: sim, a tecnologia atômica é perigosa, mas estamos em boas mãos. Os pesadelos encenados por essas obras, assim, delineavam uma situação estranha, pois ainda que fosse a radiação a causadora de uma ameaça, é apenas ela que se deve combater, não aquilo que a criou. A ciência só é um problema na medida em que não está bem domesticada a nosso serviço. O pronome "nosso" aqui é importante, pois os cenários costumam se resumir a Nós versus Eles. Nós, a comunidade humana, versus Eles, monstros radioativos ou alienígenas com uma tecnologia mais avançada que a nossa.

Sontag observa que há todo um subgênero dentro da ficção científica da época que trata do medo da perda disso que se constitui como nós. Em Veio do espaço (It Came From Outer Space, 1953), habitantes de uma cidade são substituídos por réplicas alienígenas; Guerra dos planetas (This Island Earth, 1955) apresenta humanos sendo submetidos a uma "câmara [extraterrestre] de transferência de pensamento" que suprime seu livre arbítrio e vontade; no mais famoso deles, Vampiros de almas (Invasion of The Body Snatchers, 1956), as pessoas, ao serem transformadas, tornam-se frias, sem nenhuma emoção. As novas personalidades desses corpos, embora mais eficazes como peças da estrutura social, carecem de individualidade e de sentimentos. Trata-se, paradoxalmente, do medo da alteridade entendida como fator de indiferenciação. $\mathrm{Na}$ interpretação da autora:

Assim como as vítimas sempre recuam diante do horrível abraço do vampiro, nos filmes de ficção científica a pessoa sempre resiste a "ser tomada"; ela quer reter sua humanidade. Mas, uma vez que o ato se realiza, a vítima fica eminentemente satisfeita com sua condição. Ela não se converteu de humano amável em monstruoso "animal" sedento de sangue [...], como na velha fantasia de vampiro. Não, simplesmente tornou-se muito mais eficiente - o modelo mesmo do homem tecnocrático, purgado de emoções, sem volição, sereno, obediente a todas as ordens. O segredo sombrio por trás da natureza humana costumava ser o recrudescimento do animal - como em King Kong. A ameaça ao homem, sua disponibilidade à desumanização, jazia em sua própria animalidade. Agora o perigo é compreendido como residindo na habilidade humana de se transformar em máquina (Sontag, 1965, p. 47).

Por outro lado, como observa Bidinski, a maioria dos filmes não se posicionava contra a cultura. O esquema "Nós contra os Outros" identificava o outro antes como aquilo que estava fora da cultura: 
Aquilo que é não-cultura é, de maneira mais geral, a natureza - não meramente árvores, animais e insetos, mas tudo o que é não-humano - de modo que o conflito entre moderados e extremistas, o centro e o Outro, Nós e Eles, era frequentemente apresentado como um conflito entre cultura e natureza (Bidinski, 2000, p. 225,8).

O crescimento urbano acelerado pós-Segunda Guerra nos Estados Unidos, segundo ele, criava uma paisagem "mais asfalto que floresta" (idem, p. 228,3) ou pelo menos mais domesticada (subúrbios, autoestradas, agronegócio ${ }^{97}$ ) que "selvagem" -, cada vez mais identificando Nós à cidade e Eles à natureza. Nesse jogo complexo, então, os outros podem ser animais gigantes, muitas vezes ou radioativos ou despertados por testes atômicos. Em Beginning of The End (1957), depois de comerem de uma plantação na qual se realizavam experimentos com radiação, gafanhotos tornam-se gigantes e antropófagos, destroem a zona rural e invadem Chicago. Os insetos são derrotados no final por meio de um ardil elaborado por um cientista, que os atrai para um lago gelado, onde eles perecem; essa solução vem substituir no último instante a ideia de um general que pretendia atacar os gafanhotos com uma arma nuclear, sacrificando a cidade de Chicago no processo.

Há, então, uma série de elementos no cinema de ficção científica da aurora da era atômica que podem, de modo mais ou menos grosseiro, ser resumidos assim: o medo do fim, a esperança na Ciência e no Estado diante desses eventos catastróficos e a elaboração do desastre na forma de Nós contra Eles - Eles na escala individual sendo identificados a máquinas e, na social, como a natureza.

Mas o que tudo isso tem a ver com aquele momento específico quando, no carnaval de 1959, em um país subdesenvolvido e ao sul, em uma cidade ainda não construída, um homem chamado Geraldo, junto de diversos outros operários, sentado em um precário cinema enquanto assistia a $O$ mundo em perigo, viu a projeção interrompida por tiros que sinalizavam um massacre cometido por uma polícia indistintamente privada e pública contra mais de uma centena de

97 O termo "agronegócio" foi cunhado em 1957 por John H. Davis e Ray A. Goldberg, por diferença a agricultura ou cultivo (farming), que os autores consideravam não mais capazes de nomear o novo conjunto de práticas delineado desde o fim dos anos 1940. Agronegócio diria respeito à "soma total de todas as operações envolvidas na manufatura e distribuição de suprimentos agrícolas; operações de produção na fazenda; e o estoque, processamento e distribuição de mercadorias agrícolas e itens feitos a partir deles. Assim, agronegócio essencialmente abrange hoje as funções que o termo agricultura denotava há 150 anos" (Davis e Golbderg apud Rust, 1957, p. 1043). No lugar de políticas agrícolas, os autores asseveravam que, diante do novo modelo, eram necessárias políticas públicas para o agronegócio, que dessem conta de todos os processos que envolviam fazendas, indústria e mercado. 
companheiros no acampamento vizinho? "Estava passando o filme daquelas formigas gigantes que não me recordo mais o nome." Geraldo e seus colegas foram atraídos até o meio do Brasil por promessas de trabalho em um contexto socioeconômico que pretendia acelerar o país, um projeto de "50 anos em 5", e terminaram experimentando as mais ignominiosas condições de vida. A eles impunha-se ao mesmo tempo o estatuto de máquinas da construção civil e o de animais, sub-humanos de pouca dignidade existencial. Aquilo que os frequentadores norte-americanos de cinema tanto temiam era encenado no corpo de cada um desses operários. Sua incipiente tentativa de resistência, a recusa, um dia, de ingerir alimento estragado, não foi comemorada pelo Estado, mas combatida de forma covarde. No filme que era exibido ao lado do local onde ocorreu a chacina, formigas, popularmente tidas como diligentes trabalhadoras, tornavam-se radioativas e atacavam cidades. O espectador norte-americano identificava-se com a humanidade e os insetos eram vencidos por meio de metralhadoras e um lança-chamas. Em Brasília, os operários revoltosos também eram contidos por meio de armas, desta vez empunhadas por agentes promiscuamente a serviço de empreiteiras e do governo. Quem eram Eles e quem era Nós do ponto de vista dos candangos? Interrompida por tiros, a sessão de cinema não chegou a seu final. Em lugar dele, em vez de formigas radioativas gigantes sendo dizimadas por guardas, os operários-espectadores assistiram ao assassinato de seus companheiros no alojamento da Pacheco Fernandes Dantas. Esse amargo arremedo de conclusão reverbera as mais terríveis analogias.

\subsection{2.}

Ratos

Os operários já eram máquinas e já eram bichos. Já eram Them! Mas, se assistiam a uma fita com insetos, alguns deles, não é possível saber quantos ou quais, haviam descoberto uma nova espécie de rato, nomeada em sua homenagem. Esqueçamos as fáceis comparações entre esses animais e os políticos que viriam a desfrutar da cidade; os ratos-candangos, como seus descobridores, também eram Eles, os outros com os quais os agentes da civilização do progresso não podem conviver. Não houve tempo, entre seu descobrimento e sua extinção, para que seu modo de vida fosse bem conhecido pelas ciências; em volumes que os 
mencionam, pouco se diz a seu respeito: "semifossorial, construindo ninhos subterrâneos. Habita áreas de campos cerrados com árvores esparsas e revestimento de gramíneas" (Bonvicino, Oliveira e D’Andrea, 2008, p. 37). O site do Instituto Chico Mendes de Conservação da Biodiversidade, ligado ao Ministério do Meio Ambiente, explica que a espécie "é conhecida apenas para a localidade tipo, a Fundação Zoobotânica de Brasília, Distrito Federal, que foi totalmente descaracterizada. Apesar de muitos esforços de coleta dessa espécie na natureza, nenhum indivíduo foi registrado desde 1960" (ICMBio). Em The IUCN Red List of Threatened Species, lê-se que "toda a região no entorno da localidade tipo (hoje Brasília) foi convertida de habitats nativos em um centro urbano com uma extensa e contínua expansão suburbana. A espécie extinguiu-se provavelmente logo após ter sido descoberta" (Leite e Patterson, 2008). Os ratoscandangos não apareceram ali de uma hora para outra; por não se sabe quanto tempo, o tempo necessário para se constituírem como espécie e depois o tempo que viveram como povo, esses bichos experimentaram modos de habitar aquela terra, com aquela terra, com outras espécies, as quais comiam ou pelas quais eram comidos, cavando pequenos buracos onde faziam seus ninhos.

Talvez os ratos-candangos tenham experimentado uma sensação parecida com aquela da criatura de "A construção", de Kafka; mas enquanto nesta última não era certo se havia de fato uma ameaça externa, os ratos em Brasília encontravam-se realmente diante de sua desaparição iminente. No conto, escrito entre 1923 e 1924, um vivente de hábitos fossoriais habita uma elaborada construção subterrânea e, à medida que o tempo passa, começa a temer um perigo que se mostra a ele como um barulho longínquo, que às vezes se assemelha a um animal cavando. No conto, a criatura não consegue distinguir, afinal, de onde esse barulho vem ou por quem ele é produzido, o que deixa aberta a possibilidade de que se trate apenas de sua imaginação. "A construção" costuma ser interpretado como uma espécie de metáfora para a situação do próprio escritor, sua "grande ficção autobiográfica" (Carone, 2002, p. 113); constrangido de fora pela ascensão do nazismo, visto que à época de sua escrita morava em Berlim, e de dentro, pela tuberculose que lhe afligia e viria a lhe tirar a vida, Kafka teria figurado no conto essa dupla condição. É possível, no entanto, encontrar outros sentidos nela; se levarmos a sério, por exemplo, a condição subterrânea do animal, a descrição de seu focinho, de suas patas que cavam, talvez seja possível ler a história de outro 
modo; talvez se trate mesmo de um animal subterrâneo, como eram os ratoscandangos - ainda que ele não possa ser um, já que se refere aos ratos como outros -, de um animal em sua toca, sua construção. Talvez, ainda, e apenas talvez, o som que o amedrontava fosse real. Talvez, ainda, caso esse som fosse real, a criatura estivesse diante de seu fim anunciado, vivendo-o como um dos últimos, quiçá o último, de seu povo.

Será que é possível, finalmente, entrever, no discurso inquieto e angustiado da criatura de Kafka, um eco daquilo que experimentariam os ratos-candangos no final dos anos 1960 ?

A construção fica aberta, e quem tiver vontade - é bom que se note, no entanto, que para isso são necessárias certas aptidões pouco usuais - pode invadi-la e destruir tudo para sempre. Estou bem ciente disso e, mesmo agora, no auge da vida, não tenho uma hora de completa tranquilidade (Kafka, 2002, p. 63-64).

Certamente o aparato envolvido na construção de Brasília possuía tais aptidões, e de fato destruiu tudo, todo o mundo dos ratos-candangos, para sempre. Será que eles pressentiram esse fim? Como responderam ao barulho incessante, cada vez mais próximo, de máquinas e homens que escavavam a terra para cravar nela as fundações de uma nova cidade? No conto, a criatura imagina que o som que a incomoda pode ser "produzido pelas escavações de certos animais insignificantes, que utilizaram de forma infame o tempo de minha ausência", concluindo poder ser, ele mesmo, para o propósito desses animais, apenas uma baixa colateral: "seja como for, estão longe de uma intenção dirigida contra mim, ocupam-se apenas com a sua obra e, enquanto não encontram um obstáculo no caminho, mantêm a direção já tomada" (idem, p. 90). Não há indício algum de que a extinção do Juscelinomys candango tenha sido intencional; tudo o que se sabe é que eles estavam no caminho de Brasília: hora e lugar errados.

De outra feita, a criatura quimeriza: o som a lhe torturar pode não vir de muitos pequenos animais, mas de um animal enorme, único: "Só resta a hipótese da existência do animal grande, sobretudo porque as coisas que parecem contradizer esta suposição são as que tornam o bicho, não impossível, mas sim perigoso além do concebível” (idem, p. 100). O terrível gigante, que possuiria uma "capacidade de trabalhar sem descanso" (idem, p. 103), "trabalha[ria] furiosamente", “cava[ria] o chão tão célere como alguém que passeia ao ar livre.” A própria terra sofreria com sua ação, "treme[ndo] com a escavação mesmo 
quando esta já terminou" (idem, p. 100). Neste momento, a imaginação do dono da construção conjura, como o tipo capaz de produzir aquele impacto sobre o terreno, uma espécie de bicho-escavadeira, aquela mesma máquina que, por todo o século XX e além, seria usada em obras por todo o globo:

O tipo de barulho, o zumbido ou assovio, me dá muito o que pensar. Quando eu arranho e raspo a terra a meu modo, ouve-se coisa muito diferente. Só posso explicar o zumbido pelo fato de que a principal ferramenta do animal não são as garras, mas o focinho ou a tromba, que, além da sua força descomunal, de algum modo também são afiados. Provavelmente ele enfia, com um único e poderoso golpe, a tromba na terra, e arranca um grande pedaço, nessa hora não ouço nada - é a pausa - mas depois aspira o ar outra vez para uma nova investida (idem, p. 101).

O que se lê neste trecho é a monstruosa possibilidade de um animal-máquina, pá mecânica viva, retroescavadeira hidráulica orgânica, revolvendo o solo, arrancando dele enormes porções por vez. Quase quarenta anos depois, o que os ratos-candangos viram, se puderam ver, foi algo desse tipo: um colossal exoesqueleto operado por uma pequena, em relação a ele, criatura. Muitas criaturas que trabalhavam sem descanso, não por sua própria vontade, mas porque isso era imposto a elas. "Talvez eu esteja em alguma construção alheia e o dono agora cave o seu caminho até mim" (idem, p. 103), fantasia o bicho do conto. Os ratos de Brasília, inesperadamente, encontraram-se nesta precisa condição. Por sobre, em volta, por todos os lados, de uma hora para outra, eles se perceberam parte da construção de outrem; não exatamente dos operários, mas daqueles para quem eles trabalhavam.

Talvez todo esse paralelo entre o destino do Juscelinomys candango e a criatura de Kafka talvez não seja senão um devaneio. Mas fica a questão sobre como os pequenos bichos que habitavam o solo do que se tornaria a capital do Brasil viveram o seu fim. Seu mundo efetivamente acabou ali, levando-os consigo, incapazes que eram de habitar aquele outro que se erguia. A história da modernização está repleta de histórias de extinção - de modos de vida, de relações, de possibilidades. Em Espinosa - Filosofia prática, Deleuze, a propósito dos conceitos de bom-mau presentes na Ética, explicava que ambos são "dois sentidos da variação da potência de agir: a diminuição desta potência (tristeza) é má, seu aumento (alegria) é bom” (Deleuze, 2003c, p. 74). A potência de agir, além de ser aquilo que "mantém a relação de movimento e repouso que caracteriza o corpo", é "aquilo que abre o poder de ser afetado ao maior número de coisas, é bom 'aquilo que dispõe o corpo de modo que possa ser afetado do 
maior número de modos"” (idem, p. 74-75). Não se deve, entretanto, ele continua, confundir bom e mau com Bem e Mal, acreditando que "o Mal não é nada e o Bem faz ser e agir" - é preciso sempre levar em consideração que "o bom se diz em relação a um modo existente e em relação a uma potência de agir variável e não ainda possuída" (idem, p. 75). Ele não é nunca total, do mesmo modo que o que é mau não o é. Mais tarde, no Abécédaire, para o verbete $J$ comme Joie (alegria), o filósofo explicou, a respeito da distinção entre alegria e tristeza:

Não há potências más [...] o que é mau, é preciso dizer, é o grau mais baixo da potência. E o grau mais baixo da potência é o poder. Quero dizer, a maldade, o que é? É impedir alguém de fazer aquilo que pode [...], de efetuar sua potência. Portanto não há potências ruins, há poderes maus. [...] Eu diria, todo poder é triste. Sim, mesmo se aqueles que têm o poder se alegrem muito por tê-lo, é uma alegria triste, é, há alegrias tristes. [...] Por outro lado, a alegria é a efetuação de uma potência. Mais uma vez, não conheço potências que sejam malvadas. O tufão é uma potência, ele deve se alegrar em sua alma, mas não é por derrubar casas que ele se alegra, é por ser. Alegrar-se, é alegrar-se de ser o que se é, quer dizer, de ter chegado aí onde se é. Mas não é a alegria de si mesmo, isso não é uma alegria, não é estar satisfeito consigo, a alegria, de modo algum, é o prazer de estar satisfeito consigo mesmo. É, é o prazer da conquista, como dizia Nietzsche. Mas a conquista não consiste em escravizar pessoas. A conquista é, por exemplo, para um pintor, conquistar a cor. Sim, isso, sim, isso é uma conquista. Sim. Eis a alegria (Deleuze, 1996).

A alegria, para os ratos-candangos, era viver, parafraseando a célebre fórmula de Oswald de Andrade, "desta terra, nesta terra, para esta terra" (Andrade, 1978, p. 29). Aquela terra, não qualquer terra. A terra que era deles, neles, com eles. A terra conquistada não em um sentido colonial, mas naquele em que se estabelecem relações, devires-com e nos quais se mantêm e preparam os mais criativos modos de habitação, de vida; no sentido em que se tornaram um povo. Do ponto de vista de Spinoza e Deleuze tornado cósmico, é possível dizer que os ratos eram alegres e a sua extinção foi a expressão de um poder triste.

Despret assevera, a respeito de uma outra desaparição, a dos pombospassageiros, extintos no começo do século $\mathrm{XX}$, que o que importa nela não é aquilo que a humanidade perdeu - e a humanidade perdeu muita coisa, por exemplo, os "eclipses alados" produzidos pelo voo conjunto de um número incontável deles no céu ${ }^{98}$ (Despret, 2017, p. 3777) -, mas o que foi perdido pelo mundo:

\footnotetext{
${ }^{98}$ Há uma série de relatos de naturalistas no século XIX a respeito da quantidade enorme de pombos-passageiros que havia então. Alexander Wilson, por exemplo, contou que estava no Kentucky quando "fui subitamente surpreendido por um assombro diante de uma acelerada
} 
O que o mundo perdeu, e o que verdadeiramente importa, é uma parte do que o inventa e o mantém como mundo. $\mathrm{O}$ mundo morre com cada ausência; o mundo se rompe com cada ausência. Pois o universo, como os grandes e bons filósofos disseram, o universo inteiro se pensa e se sente a si mesmo, e cada ser importa no tecido de suas sensações. Cada sensação de cada ser do mundo é um modo pelo qual o mundo se vive e se sente, e pelo qual ele existe. E cada sensação de cada ser do mundo faz com que todos os seres do mundo se pensem e se sintam diferentemente. Quando um ser não existe mais, o mundo se estreita de repente, e uma parte da realidade colapsa. A cada vez que uma existência desaparece, é um pedaço do universo de sensações que desaparece. [...] Mas o que o mundo perdeu ainda mais foi o ponto de vista único, sensual, vivo, quente, musical e colorido que o pombo-passageiro criou nele e com ele. Esse ponto de vista único, a que o mundo deveu a sensação de tantas coisas, não existe mais. A felicidade de ser uma imensa asa atravessando espaços infinitos; o sentimento de ser uma nuvem por sobre a Terra e de criar formas variáveis nela, fluidas e escuras; a sensação dos campos e dos bosques que, lá embaixo, voavam como imagens em um filme acelerado. A alegria de ser inumerável e de formar um ser perfeitamente afinado, e a confiança nessa afinação, que é a figura de alegria que os pombos-passageiros inventaram quando aprenderam a confiar no ar e no vento. O mundo perdeu o gosto de frutas secas e carnudas, de sementes e insetos, gotas de chuva que deslizavam de penas, o ar que dança e modela os caminhos do calor e da densidade, a música no murmúrio pulsante de milhares de asas aplaudindo o voo, o chiado de árvores e galhos sendo sacudidos sob o peso do descanso, o brilho de um arco-íris que varre em busca do horizonte... A percepção da vastidão, da inocência [blancheur] de um ovo e do grito de um pequenino que se sente abandonado. Tudo isso não existe mais. A humanidade pode fazer luto pelo pombo-passageiro. Mas é o mundo que se rompe (idem, p. 3777-4275).

Em um outro texto, chamado "Letter to the artist", dirigido a Alexis

Rockman, a autora diz que as extinções, na medida em que são perdas de pontos de vista sobre o mundo, tornam-no mais pobre ontologicamente:

Se a realidade mesma deste mundo é composta de pontos de vista múltiplos sobre ele, de diferentes maneiras de viver nele e de habitá-lo, de todos os usos, invenções e percepções que o fazem existir e lhe dão sua espessura e densidade ontológicas, então, com cada extinção, uma parte da realidade se perde (Despret, 2013, s/p).

Ela cita, como imagem dessa perda, um trecho do romance Sans l'orang-outan, de Éric Chevillard, no qual é descrita a morte do último dos orangotangos:

O ponto de vista do orangotango, que não significou pouca coisa na invenção do mundo e que segurava o ar no globo terráqueo, com suas frutas carnudas, seus cupins e seus elefantes, esse ponto de vista único ao qual se deve a percepção dos trinados de tantos pássaros cantores e aquela das primeiras gotas de orvalho sobre as folhas, esse ponto de vista não existe mais, você se dá conta [...] o mundo de repente encolheu [...]. É todo um aspecto da realidade que colapsou, uma

descarga estrondosa sucedida por escuridão instantânea [...] Tomei aquilo por um tornado em vias de arrasar a casa e destruir tudo em volta" (Wilson apud Barrow, 2009, p. 2103). O bando demorou mais de quatro horas para passar e Wilson calculou que deveria haver mais de 2,2 bilhões de aves. 
concepção completa e articulada dos fenômenos que fará falta doravante à nossa filosofia" (Chevillard, 2007, p. 18).

O mundo, em uma palavra, empobrece a cada extinção. É curioso que Chévillard mencione a filosofia, que, em parte de sua história, pelo menos a majoritária, se esforçou para retirar dos animais qualquer ponto de vista, culminando na famosa teoria acerca de sua pobreza de mundo. Seguindo Chévillard, é possível se perguntar se o mundo dos animais é pobre nele mesmo ou se é o mundo configurado pelo anthropos que é cada vez mais pobre; este homem que fala e forma mundos empresta seu nome a uma época cujo próprio é a pobreza ontológica. Heidegger escreveu que "o salto do animal vivente ao homem falante é tão grande, ou até maior, que o da pedra sem vida ao ser vivo" (Heidegger, 2004, p. 76). No Antropoceno, essa afirmação perde seu caráter supostamente descritivo e aparece como uma tarefa que o configurador de mundos tomou para si: aproximar cada vez mais os animais das pedras, transformando-os em fósseis. A clareira do ser, isto é, o deserto.

O que o mundo perdeu com o fim dos ratos-candangos? Eles nunca foram tantos quanto os pombos-passageiros e viviam em apenas uma localidade; não migravam, não causavam eclipses com asas. Viviam em seu território, um território imaginado em conjunto com a terra, confiavam nela para construir seus ninhos, dentro dela, e aí proteger suas crias. Se ser um, como dizia Haraway, é uma questão de tornar-se com muitos, então todos aqueles que se tornavam com os ratos tornaram-se mais pobres, capazes de menos coisas. A terra ela mesma, que nunca mais experimentou-se escavada pelas pequenas patas que depositavam nela a esperança de seu futuro, seus filhotes, pode-se dizer, ficou triste. Talvez a alegria possa ser compreendida na escala de uma espécie como o conjunto de invenções expressivas co-criadas por ela e pelos outros que a co-constituem e que ela co-constitui. Talvez a alegria, nesse contexto, seja a invenção de um povo, e a tristeza, por outro lado, aquilo que separa um povo de seu mundo. Cada extinção, assim, é um evento triste, que diminui a potência de tantos que compõem e fazem mundos de ser afetados, que diminui a potência do próprio universo, jamais afetado do mesmo modo novamente. É o fim de conquistas e de devires. O fim de uma alegria. 


\section{2. \\ Casa mal-assombrada}

As duas espécies mencionadas neste capítulo, Juscelinomys candango e Ectopistes migratorius, pereceram ambas pela agência humana; a primeira, pela destruição de seu habitat, a segunda, por uma série de fatores que envolveram desde a caça desregulada até o desmatamento para abertura de áreas para agricultura $^{99}$. Não se tratou de qualquer humanidade, que fique claro - nenhum desses animais vivia em áreas desabitadas por humanos, mas de um mau encontro com aquela civilização que parece ter se especializado em diminuir potência de tudo o que não é ela mesma. Ambos os animais viviam no chamado Novo Mundo, um na América do Sul, o outro na do Norte e não foi senão depois da invasão por colonizadores que seu crepúsculo começou a ser gestado.

Ratos-candangos e pombos-passageiros são ambos espécies extintas, que não são mais encontradas vivas em nenhum recôndito do planeta. Mas, se é possível afirmar, como fizemos, que toda extinção é um evento triste, não se pode deixar de frisar que elas não acontecem todas do mesmo modo:

Das quatro bilhões de espécies que se estima terem evoluído na Terra nos últimos 3,5 bilhões de anos, cerca de 99\% desapareceram. Isso mostra o quão comum é a extinção, mas ela é normalmente equilibrada pela especiação (Barnosky et alii, 2011, p. 51).

Dito de outro modo, a tristeza de cada extinção costuma ser contrabalançada pela alegria do surgimento de novas espécies, novos povos, novas e outras formas de mundificação. A vida, esse devir desenfreado da matéria decidindo seu sentido, como diziam Margulis e Sagan, procede assim, por experimentação, em um ciclo contínuo de criação, adaptação e morte. Por cinco vezes, entretanto, e por motivos

99 Os pombos-passageiros passaram de bilhões a zero em uma questão de décadas; os estimados 3 a 5 bilhões deles que viviam na América do Norte em meados do século XIX haviam desaparecido completamente em 1914 quando a última sobrevivente, uma fêmea chamada Martha (em homenagem à primeira dama Martha Washington), faleceu de causas naturais em sua gaiola no Zoológico de Cincinnatti (cf. Barrow, 2009). Por quatro anos, desde que seu último companheiro, George, perecera, Martha viveu como a última remanescente de sua espécie. Embora houvesse alguma esperança de que o casal procriasse, eles se recusaram; nas palavras de Despret, "os dois tinham sido a última chance da espécie. Declinaram. Preferiram não deixar nenhum descendente. Imagino que ela, Martha, deva ter fechado seus olhos, tranquila. Ela completara sua primeira migração e a última para todos aqueles cuja existência ela prolongou por diversos anos. Ou o que é chamado de uma existência - um longo momento de abstração, uma existência sem céu. Uma má aposta existencial. Martha deixou de existir em um mundo que não era mais o que havia sido. Deixe o mundo seguir sem nós. Ela se juntou a seu parceiro e a seu gênero. Deixe toda essa história terminar..." (Despret, 2017, p. 3734). 
tão diversos quanto mudanças atmosféricas e colisões, mais de 75\% das espécies foram varridas do planeta, eventos de extinção em massa conhecidos como as "Cinco Grandes". E, a não ser no caso do bólide que se acredita ter se chocado com a Terra durante o Cretáceo, impulsionando uma redução de $76 \%$ no número de espécies em menos de um ano, os outros tomaram um período de tempo que variou de centenas de milhares a milhões de anos ${ }^{100}$ :

A extinção em massa, no sentido paleontológico, se dá quando a taxa de extinção se acelera e relação às taxas de originação, de modo que mais de $75 \%$ das espécies desaparecem em um intervalo geológico curto - tipicamente menos de 2 milhões de anos, em alguns casos muito menos (idem, p. 52).

A última dessas extinções, justamente a do Cretáceo, ocorreu há cerca de 66 milhões de anos. Ela marca não apenas o fim deste período, como também o da era Mesozoica, que deu lugar à Cenozoica, do grego kainós mais zoé, isto é, "nova vida”, na qual vivemos hoje, no período Quaternário, no começo da época do Antropoceno. Atualmente, a comunidade científica debate a possibilidade de estarmos diante da Sexta Grande Extinção, de origem antropogênica: as estimativas mais conservadoras apontam para uma taxa de extinção cem vezes maior que a fundo, e há estudos indicando que ela chegaria a mil vezes, podendo alcançar dez mil proximamente (cf. Ceballos et al, 2011; de Vos et al, 2015). Mesmo que ainda haja um debate sobre a legitimidade do termo "extinção em massa" para designar o evento, com autores afirmando que "a recente perda de espécies é dramática e séria mas ainda não se qualifica [...] no sentido paleontológico das Cinco Grandes", havendo "muito da biodiversidade do mundo para salvar" (Barnosky et alii, 2011, p. 56) e sendo "ainda possível, através de esforços de conservação intensificados", evitar a perda de serviços ecossistêmicos (Ceballos et alii, 2015, p. 1); mesmo que ainda se possa acreditar que "é cedo demais para dizer que as proporções das Cinco Grandes serão alcançadas" (Kolbert, 2014, p. 8,7), o fato é que "a janela de oportunidade está se fechando rapidamente" (Ceballos et alii, 2015, p. 1), o cenário é "desanimador", as "ameaças, terríveis e progressivas" (Barnosky et alii, 2011, p. 56); "as taxas disparam, muda a textura da vida" (Kolbert, 2014, p. 8,7).

Talvez a maior dificuldade na definição da Sexta Extinção como um evento massivo resida no desconhecimento do número de espécies que habitam a Terra

${ }^{100}$ Mesmo a estimativa a respeito da duração da Grande Extinção do Cretáceo varia entre menos de um ano até dois milhões e meio de anos (cf. Barnosky et al, 2011). 
hoje, o que impossibilita a determinação precisa de quantas/quais estariam desaparecendo. Um estudo recente, entretanto, acessando dados disponíveis sobre espécies conhecidas, apontou para um complicador que pode ficar mascarado caso se considerem apenas as espécies extintas, qual seja, a diminuição de populações, em número e em área, e suas consequências para a manutenção de ecossistemas:

\begin{abstract}
Descobrimos que a taxa de perda de população em terrestres vertebrados é extremamente alta - mesmo "espécies de pouca preocupação" [segundo a classificação do IUCN]. Em nossa amostra, que compreende quase metade das espécies de vertebrados conhecidas, 32\% (8.851/27.600) estão diminuindo; isto é, diminuem em tamanho e distribuição. Todos os 177 mamíferos sobre os quais temos dados detalhados perderam $30 \%$ ou mais de sua distribuição geográfica e mais de $40 \%$ das espécies experimentaram declínios severos na população (>80\% de encolhimento). Nossos dados indicam que para além das extinções globais de espécies, a Terra está experimentando um enorme episódio de declínio de populações e de extirpações, que terão consequências negativas em cascata para o funcionamento e os serviços ecossistêmicos vitais na sustentação da civilização. Descrevemos isso como uma "aniquilação biológica" para sublinhar a atual magnitude do grande evento de extinção em curso na Terra (Ceballos et alii, 2017, p. 1).
\end{abstract}

Aniquilação biológica, portanto, talvez seja um nome mais apropriado para o amplo processo, que envolve as extinções, pelo qual passa a biota terrestre, "pressionada por implacáveis processos de perda de habitat, exploração direta e mudança climática, entre outros" (Rose, van Dooren e Chrulew, 2017, p. 217). Trata-se de uma ocorrência de extermínio da vida, seja em espécies inteiras ou em populações - povos, poderíamos dizer. Nesse sentido, seria possível sugerir que a Sexta Extinção consiste em um estado de genocídio generalizado, de escopo planetário. Assim, se pensarmos o Antropoceno, não apenas sob o modo de uma época geológica, mas como um sistema de governo, este seria um regime de exceção. Subversivos pelo desacordo entre seu modo de vida e aquele aceito pelo poder que se impõe sobre eles, inumeráveis povos animais sucumbem diariamente, caçados direta ou indiretamente - por "conversão de habitats, distúrbio do clima, superexploração, toxificação, invasão de espécies, doença" (Ceballos et al, 2017, p. 7). São os desaparecidos do Antropoceno. Desaparecidos políticos, criminosos radicais na monocultura civilizacional.

Tal regime genocida traz consigo macabras consequências: causar a desaparição de uma parte enorme dessa que é considerada a "biota terrestre mais rica de todos os tempos" (idem) enfraquece também a chance de continuidade da vida humana no planeta: 
A perda generalizada de populações já está danificando os serviços que os ecossistemas proveem à civilização. Quando consideramos este ataque assustador às fundações da civilização humana, não se deve jamais esquecer que a capacidade da Terra de sustentar a vida, incluindo a vida humana, foi modelada pela vida ela mesma (idem).

Isto é, os ataques à biodiversidade comprometem a possibilidade da manutenção da espécie humana, que jamais viveu só e também co-constituiu-se em uma multiplicidade de povos em conjunto com outros seres. A defaunação é, no limite, suicida. Ou, dito de outro modo: a Sexta Grande Extinção, antropogênica, transforma a Terra em uma enorme casa mal-assombrada, hiperbólica e inescapável, seus espíritos vingativos agindo contra a humanidade cuja civilização foi erguida por sobre um grande cemitério.

\section{3. Zumbis}

Quando um habitat é alterado ou degradado de tal forma que a rede de conexões que formava determinado ecossistema é rompida, ainda que haja poucas ou nenhuma extinção imediata, ocorre um “débito de extinção ${ }^{101}$ ", um tipo de desaparição anunciada: mesmo que ainda sobrevivam por um tempo, a perda de articulações necessárias à continuidade de determinadas espécies as condena à morte $^{102}$. Isto é, ainda que essas espécies continuem existindo, não há mais esperança para elas; é como se entrassem em uma existência suplementar, como quando depois de uma frenagem brusca as rodas de um veículo continuam deslizando por um tempo ou quando, segundo se conta, depois de uma decapitação por guilhotina, a cabeça separada do corpo ainda pisca algumas vezes. São espécies e populações mortas andando ${ }^{103}$.

${ }^{101}$ Débito de extinção refere-se a "o número ou proporção de espécies extantes especialistas do habitat focal que se espera em algum momento tornarem-se extintas à medida que a comunidade [ecológica] alcança um novo equilíbrio depois de perturbações ambientais tais como destruição de habitat, mudança climática ou invasão de novas espécies. Em espécies individuais, o número ou proporção de populações que se espera tornarem-se extintas depois de mudança de habitat" (Kuussaari et al, 2009, p. 564). Para discussões aprofundada sobre o conceito de débito de extinção, cf. Tilman et al, 1994; Vellend et al, 2006; Kuussaari, 2009.

102 "Cada espécie é um fio em um tecido [...] espécies são modos em evolução de vida, como linhas entrelaçadas de movimento intergeracional através da história profunda. Nesse contexto, a extinção toma sempre a forma de um desemaranhamento de modos de vida coformados e em co-formação, um desemaranhamento que começa muito antes da morte do último indivíduo e continua a ecoar muito depois" (van Dooren, 2017, p. 3329).

103 O geofísico David Jablonski cunhou em 2002 o termo "Clado Morto Andando", em referência ao romance Dead Man Walking, de 1993, escrito por Helen Prejean e cuja adaptação 
Em Ubik, romance de Philip K. Dick, há uma tecnologia que permite às pessoas, depois de mortas, serem mantidas em um tipo de suspensão animada chamada "meia-vida [half-life]" (cf. Dick, 2009), tempo em que ainda é possível, por exemplo, sua comunicação (por uma espécie de fone de ouvido) com os vivos. O fim não é exatamente revertido, apenas adiado: o morto, ligado a máquinas, pode ser trazido à meia-vida por um período limitado de tempo, durante o qual vai se deteriorando até que desapareça de vez. Uma pessoa morta, devido a um aparato biotecnológico, pode ser "revivida" por um tempo determinado; a cada vez que é trazida, entretanto, parte desse tempo é gasto até que finalmente a morte a vença. No âmbito da biologia da conservação, "meia-vida" refere-se ao tempo necessário para que metade do débito de extinção seja pago, isto é, para que metade das espécies condenadas efetivamente desapareça. Esse tempo é variável, a depender de fatores como isolamento, área, densidade e grupos taxonômicos, entre outros (cf. Hanski e Ovaskainen, 2002; Halley, Iwasa, 2010; Halley et al, 2016). No livro de Dick, não é qualquer morto que está apto à meia-vida; o tempo desde o óbito e o estado do corpo são essenciais para que ainda haja "alguma meia-vida residual", conforme explica von Vogelsang, sócio de um dos moratórios nos quais é oferecido o serviço. No caso do débito de extinção, o tempo até a primeira extinção é importante, pois ele indica o começo do chamado período de relaxamento, a partir do qual as espécies começam a desaparecer; quando se chega à meia-vida, isso significa que metade da vida residual já se dissipou. Ele marca "um importante limiar" em qualquer esforço conservacionista que se preocupe em evitar ou desacelerar o processo das extinções "através do reestabelecimento da conectividade entre habitats remanescentes ou da recuperação da terra degradada" (Halley et al, 2016, p. 4). Em Ubik, a esposa do narrador, Ella, encontra-se no estado de meia-vida; à certa altura, quando seu discurso começa a ficar confuso, sinal de que o tempo dela estaria próximo do fim, o narrador reflete:

No fone de ouvido, palavras lentas e incertas se formavam: pensamentos circulares sem importância, fragmentos dos sonhos misteriosos que ela, agora, habitava. Qual

para o cinema em 1995 foi dirigida por Tim Robbins; "homem morto andando", a tradução do título, foi uma expressão usada no sistema prisional norte-americano para designar a última caminhada de um prisioneiro no corredor da morte. "Como muitos sobreviventes de extinções em massa não participam das diversificações pós-recuperação, e portanto caem em um padrão que pode ser chamado Clado Morto Andando (CMA), os efeitos das extinções em massa se estendem para além das perdas observadas durante o evento ele mesmo" (Jablonski, 2002, p. 8139). 
era a sensação, ele se perguntou, de estar em meia-vida? Ele jamais poderia compreender, a partir do que Ella havia lhe contado. A parte fundamental, a experiência em si, não poderia ser transmitida de fato. A gravidade, ela lhe dissera uma vez, começa a não afetar a pessoa, que passa a flutuar, mais e mais. Quando a meia-vida acaba, ela disse, acho que você flutua para fora do Sistema, para as estrelas. Mas nem ela sabia, apenas imaginava e conjeturava (Dick, 2009, p. 17).

Nos habitats fragmentados, enquanto desfrutam de suas meias-vidas, um número incontável de animais (milhões? bilhões? mais?) hoje também habita sonhos estilhaçados; à medida que se perde conectividade, perde-se a possibilidade de devir-com e, assim, de co-constituir mundos. Ella imagina que flutuará em direção às estrelas depois de sua segunda morte; se for assim, os condenados por débito de extinção talvez encontrem seus antigos companheiros no espaço a formar vertiginosas constelações-povos.

Essas espécies também são conhecidas como "mortas-vivas [living-dead species]" (cf. Sohdi, Brook e Bradshaw, 2008), como os zumbis do cineasta George Romero. A noite dos mortos vivos (Night of the living dead), título de seu primeiro longa-metragem, aliás, parece um nome apropriado para o Antropoceno, essa época cheia de mortos que caminham sobre a Terra. A respeito da relação entre zumbis e extinção, a antropóloga Genese Sodikoff comentou que:

A adoção, por parte dos biólogos conservacionistas, da metáfora do zumbi (...) e a imensa popularidade dos temas apocalípticos e de zumbi nas TVs europeia e americana diz algo sobre a experiência subjetiva da mudança planetária no Norte do globo e sobre os modos como projetamos a forma das coisas que virão. "Este é nosso evento de extinção", diz um personagem na série de zumbis The Walking Dead (Sodikoff, 2013, p. 142).

O possessivo "nosso", na expressão "nosso evento de extinção", aponta para dois significados: trata-se da extinção antropogênica, deflagrada por "nós", humanos, e, ao mesmo tempo, da "nossa" extinção, a extinção da humanidade - mas é a segunda acepção que predomina nesse imaginário. Nem na série citada por Sodikoff nem nos filmes de George Romero, por exemplo, os animais costumam ser levados em consideração. No mais das vezes são imunes à epidemia ou são mera comida de zumbi (e de humanos). Em uma cena emblemática do primeiro episódio de The Walking Dead, seu protagonista, o ex-policial Rick, que acorda no hospital em pleno flagelo zumbi e decide ir procurar a família, ao constatar que não há combustível em seu carro, monta gloriosamente um cavalo, e cavalga em direção ao pôr-do-sol - comentário não apenas sobre o fim da civilização precipitando o retorno a outras formas de habitar o mundo, como também uma 
piscadela ao gênero western e à conquista da última fronteira, agora descivilizada; é o apocalipse engendrando cowboys. No segundo episódio, quando os mortosvivos cercam o herói e seu animal, o cavalo, tendo já cumprido sua função de símbolo, é prontamente descartado e usado como isca para que Ricky consiga escapar, sendo devorado vivo pelos monstros em uma sequência repleta de sangue e entranhas. Aliás, se cabe um comentário geral sobre os filmes de zumbi é que eles costumam se desdobrar em um ambiente social radicalmente humano: em vez de caçarem ou plantarem, os personagens comem comida enlatada. Fazem expedições às cidades desertificadas para pilhar bens produzidos pela antiga sociedade de consumo; vivem deles. Nessas obras, perde-se toda a referência ao mundo externo.

Mas nem sempre é tão simples. Em $O$ dia dos mortos (Day of the dead, 1985), também de Romero, o mundo pós-apocalíptico se concentra em uma base militar, e os humanos remanescentes são governados por dois poderes: o exército, de um lado, e a ciência, de outro. Os zumbis são sistematicamente capturados por soldados para servirem de cobaias para cientistas; esses experimentos sangrentos e repugnantes são mostrados em detalhe e espelham a relação entre animais outros que humanos e cientistas em laboratórios. Nesse filme, os zumbis são animalizados - e quando tomam a base militar, no final, destruindo os poderes que os assujeitavam, a revolta dos sub-humanos animalizados acena também para uma possível vingança de todas as cobaias e escravos do mundo.

Em dois filmes irlandeses de baixo orçamento de meados dos anos 2000, Banquete de zumbis (Dead Meat, 2004) e Quarentena (Isolation, 2005), a exploração desmesurada dos animais de produção é o estopim da epidemia. No primeiro, príons mutantes transformam animais infectados com a Doença da Vaca Louca em antropófagos mortos-vivos que passam a doença adiante - "não se trata do que você come, mas de quem você come", anuncia a tagline. À exceção de duas vacas, entretanto - a "paciente zero", que dilacera seu criador, e outra que aterroriza os sobreviventes no meio do filme -, em todo o restante da fita é preciso se defender dos humanos zumbificados. O fim do filme, porém, espelha o início e oferece uma identificação macabra. A abertura apresentava imagens de gado sendo transportado em condições de superlotação, seus olhos desesperados visíveis por entre as tábuas que os mantinham presos. No final, agentes portando macacões impermeáveis e máscaras respiratórias, provavelmente a serviço do 
Estado, em vez de salvar os humanos, os prendem em caminhões e os fecham do mesmo modo como se faz com o gado. No lugar de focinhos, são mãos de Homo sapiens em gestos atormentados o que se vê passar por entre as ripas.

Já em Quarentena, o criador de animais Dan cede sua propriedade e participa de experimentos genéticos conduzidos por cientistas com o objetivo de produzir gado mais fértil e que cresça mais rápido, sendo assim mais rentável. Dan, de modos tradicionais, explica que vem de uma linhagem de criadores e aceitou tomar parte nos experimentos por falta de dinheiro. A coisa toda dá errado, porém, produzindo um mortífero ser mutante que infecta animais e humanos, usando-os como hospedeiros para misturar suas células às deles. Nisso, Quarentena lembra o clássico de terror de John Carpenter, O enigma de outro mundo (The Thing, 1982), no qual uma criatura alienígena se instala em corpos animais (primeiro um cachorro, depois humanos) e os assimila; uma das taglines desse filme dizia "O homem é o lugar mais caloroso [warmest] para se esconder." A fita irlandesa retoma essa ideia, localizando a origem do mal no modo como os animais são tratados pelos modernos complexos industriais de produção, que os toma por objetos - é isso o que Dan diz ao cientista responsável pelo experimento: "Eles não são animais para você, não é verdade? São apenas cobaias! [...] Você matou minha fazenda, você é maligno!" Quarentena não é exatamente um filme de zumbi, mas coincide com eles em vários de seus temas, como o da infecção que, caso se alastre, pode exterminar toda a humanidade. $\mathrm{O}$ filme termina com a única sobrevivente da fazenda em um hospital, grávida, percebendo, apavorada pelas imagens da ultrassonografia, que gesta um monstro - enquanto o inocente médico a parabeniza: "Você não precisa mais se preocupar. Tem um bebê perfeitamente saudável!"

É interessante notar que o uso do termo "mortos-vivos" no âmbito da biologia conservacionista e no audiovisual é equívoco. De um lado, trata-se de espécies condenadas à desaparição; do outro, quando animais são convocados, de uma situação quase contrária: os bichos se tornam mutantes ou causam infecções devido a seu número exacerbado e à promiscuidade das interações genéticas entre eles e humanos. "Morto-vivo", assim, diz respeito tanto à extinção quanto à multiplicação desvairada. Em ambos os casos, no entanto, o que está em jogo é uma espécie de necropolítica perversa que não apenas mata, mas decide quando se pode morrer - no caso dos animais de produção, por quanto tempo serão 
mantidos em condições miseráveis de existência até que finalmente sejam mortos. Haraway comentou, em conversa com o filósofo Cary Wolfe, sobre aquilo que considera "a terrível violência de fazer viver" (Haraway, 2016a, p. 228): “As vastas máquinas de vida forçada com o propósito de extração de valor, com o propósito do abate. As múltiplas máquinas de vida-forçada são talvez a maior fonte de violência em nosso planeta, se estivermos falando de outras criaturas" (idem, p. 229). Nesse sentido, extinção e vida-forçada talvez sejam modos diferentemente cruéis de criar zumbis.

Nem os já-extintos estariam imunes a essa política, que ainda lhes reserva um outro modo de zumbificação: trata-se dos projetos de desextinção que pretendem trazer de volta à vida espécies já desaparecidas. Hoje, diversas iniciativas que envolvem universidades, museus e fundações investem recursos no esforço de voltar a fazer viver. Há uma boa dose de controvérsia em torno dessas iniciativas, e que diz respeito a possíveis velhas e novas doenças ou à diminuição da diversidade genética, entre outros problemas (cf. Minteer, 2014). Além desses, é também necessário decidir quais critérios devem ser usados para definir as espécies a serem objetos de ressurreição. Em 2014, usando como modelo as Diretrizes para reintroduções e outras translocações para fins de conservação, da IUCN, um grupo de estudiosos desenvolveu um quadro de perguntas a serem levadas em consideração nessas decisões. Algumas dessas perguntas incluem:

1. As causas passadas e futuras da extinção podem ser identificadas e abordadas? [...] 4. Há uma área suficiente de habitat adequado e apropriadamente administrado disponível agora e no futuro? [...] 6. As circunstâncias socioeconômicas, as atitudes das comunidades, os valores, as motivações, as expectativas e os benefícios e custos antecipados têm uma probabilidade razoável de serem aceitos pelas comunidades humanas dentro e no entorno da área de soltura? 7. Há algum risco de impacto negativo sobre as espécies, comunidades ou sobre o ecossistema da área que vai recebê-las? [...] 9. Há risco aceitável de um impacto nocivo para os humanos? 10. Será possível remover ou destruir indivíduos translocados e/ou sua prole da área de soltura ou de uma área mais ampla na eventualidade de impactos ecológicos e socioeconômicos inaceitáveis? (Seddon, Moehrenschlager e Ewen, 2014, p. 142-144).

Tais questionamentos, que trazem à memória a intriga de Jurassic park - o Parque dos dinossauros (Jurassic Park, 1993), de Steven Spielberg, no qual cientistas e ricaços excêntricos criam uma reserva florestal insular para abrigar suas criações, dinossauros ressurgidos que eventualmente se voltam contra seus criadores, parecem mais impedir o projeto que viabilizá-lo, desde o primeiro 
deles; pois como tratar das causas da extinção se são essas causas mesmas o sustentáculo da civilização de crescimento contínuo?

É como se o Antropoceno enquanto época geológica e sistema de governo fosse terrivelmente eficaz em tornar concebível neste mundo aquele do horror e da ficção científica. Senão, como explicar que pareça menos incrível satisfazer todos os critérios para a zumbificação dos extintos do que habitar o mundo imaginado por Philip K. Dick em Androides sonham com ovelhas elétricas?? No romance, a Guerra Mundial Terminus exterminou a tremenda maioria dos animais, e possuir um deles, coisa raríssima, é sinal de distinção tal que se desenvolveu todo um mercado de réplicas eletrônicas, compradas pelos mais pobres. Isto é, a categoria de animalidade, ainda que transfigurada por componentes eletrônicos, é convocada para que a humanidade possa se conceber como domínio autônomo. Esses animais-máquinas, numa atualização distópica do delírio de Descartes, infestam a Terra pós-catástrofe e reasseguram os sobreviventes de seu status existencial - a empatia que se sente por eles é prova de pertencimento à espécie humana e uma das maneiras pelas quais se distinguem os verdadeiros dos androides. As ovelhas de Dick provavelmente responderiam aos que fantasiam sobre ressurreições que elas só podem retornar como máquinas, seus duplos tal como sonhados pela modernidade.

Nos filmes ou nos seriados - e mesmo no contexto científico -, com raras exceções, os mortos-vivos são sempre outros, a serem temidos ou salvos. Mas, se consideramos que nessas narrativas o que a infecção zumbi causa é a transformação dos contaminados em novos zumbis, isto é, a transformação da alteridade na mesmidade, talvez essa figura ganhe um outro sentido. A esse respeito, Sodikoff comentou que

As criaturas sugadoras de vida que nos fascinam na tela e nas páginas dramatizam e invertem a relação entre humanos e não-humanos. Do ponto de vista, digamos, de um carneiro-da-Barbária, de um trilho de Guam ou de um membro de qualquer das espécies que foram extintas na natureza, os humanos são os monstros a serem temidos (Sodikoff, 2012, p. 11).

O que o imaginário da epidemia zumbi cria é uma reversão da relação da chamada civilização com outros povos, sub-humanos e não-humanos. Estamos "nós", os humanos, histéricos diante da possibilidade do "nosso evento de extinção", o fim do nosso mundo. Temos medo de que, como górgonas do desenvolvimento, acabemos nos olhando no espelho, tornando-nos pedras - ou fósseis. Enquanto 
isso, para a manutenção do que se alega querer salvar, são aniquilados diariamente muitos mundos e pontos de vista. De súbito, todos os fantasmas se levantam, apontam para nós e as perspectivas embaralhadas encontram seu lugar. Damo-nos conta de que não temos o que temer. Somos nós os zumbis.

\section{4 . Histórias de vivos e de fantasmas}

No decurso deste capítulo, utilizou-se a expressão "extinção de origem antropogênica" e o pronome "nós" de forma equívoca, sem que seu sentido estivesse sempre explícito. "Nós" pode ser muito bem uma questão de enunciado ou perspectiva e, por isso mesmo, é preciso tomar cuidado ao inferir a quem esse termo se refere. No contexto dos filmes de ficção-científica e terror dos anos 1950, "nós" dizia respeito a grupos norte-americanos (espectadores e populações citadinas, por exemplo) que não se confundiam com o "nós" que assistia ao filme no cinema improvisado das construtoras de Brasília; nos filmes de zumbi de que falamos, o sentido pode variar - da humanidade própria em Walking Dead à indiscernibilidade do gado-bicho/gado-gente em Banquete de zumbis. Do mesmo modo, a expressão "origem antropogênica', que evoca o anthropos, pode ser entendida como dizendo respeito a toda a humanidade, um ato de espécie. Esse tipo de compreensão universal, entretanto, é sempre perigosa - pois mesmo as espécies não se comportam de maneira unívoca, havendo diferenças entre populações e grupos, ou, como vimos falando, povos. Assim, na atual época geológica que possui como uma de suas marcas a destruição de incontáveis modos de vida, as agências da aniquilação não devem se confundir com a espécie humana em geral, como se esta fosse amaldiçoada de nascença ou estivesse cumprindo um destino inexorável. Além disso, o próprio conceito de espécie foi cunhado por um certo povo, como explicam Danowski e Viveiros de Castro:

a questão de saber quem é o "nós", o que se entende por "humano" ou "pessoa" em outros coletivos consensualmente considerados (por "nós") como humanos, raramente é colocada, e de qualquer modo jamais ultrapassa o limite da espécie enquanto categoria taxonômica extensiva. A abordagem desta questão é uma tarefa estratégica, para a qual a antropologia empírica ou a teoria etnográfica está muito mais bem preparada, diríamos, que a metafísica ou a antropologia filosófica, as quais quase sempre parecem saber perfeitamente que gênero de entidade é o anthropos, e, acima de tudo, quem está falando, quando se diz "nós" (Danowski e Viveiros de Castro, 2017, p. 373). 
Não há condição, aqui, de abordar tal questão, para a qual, ademais, “antropologia empírica ou a teoria etnográfica está muito mais bem preparada." O objetivo, muito mais modesto, é tentar delinear quem é referido quando se define a extinção em massa como sendo "de origem antropogênica." A civilização baseada na queima de combustíveis fósseis, explicou Haraway, é aquela comprometida com a produção acelerada de novos fósseis (cf. Haraway, 2016b, p. 46). Queimando fósseis antigos, não se para de criar novos fósseis. Entretanto, se é possível apontar a civilização - o modo de vida -, ainda assim não se pode afirmar que todos aqueles que a compõem são igualmente responsáveis (ou irresponsáveis, no sentido que a filósofa dá a esse termo). Isto porque nem todas as agências se equivalem nesta civilização e, além do mais, as redes e estruturas que a compõem hoje são tão pervasivas que sequer permitem traçar a linha exata onde ela começa e termina. Ou seja, não só o poder de ação não é equivalente, como não se tem as mesmas escolhas - a ponto de muitas vezes não ser possível decidir tomar ou não parte nela. As alternativas infernais capitalistas de que falava Stengers proliferam em todas as dimensões, desde aquelas que compreendem políticas públicas até as muito menores, que podem envolver, por exemplo, comer carne produzida em área desmatada ou simplesmente não comer, no caso das populações citadinas mais desvalidas. É, portanto, imprescindível compreender o anthropos que compõe o "antropogênico" (e mesmo o Antropoceno) a partir de um ponto de vista situado, nomeando as suas agências. E, conforme mostra o luminoso parágrafo de Danowski e Viveiros de Castro em Há mundo por vir?, os principais causadores e mantenedores da aniquilação, de dentro desta civilização, podem de fato ser chamados por seus nomes próprios:

Para começar, apenas noventa grandes companhias são responsáveis por dois terços das emissões de gases de efeito-estufa na atmosfera terrestre: Chevron, Exxon, BP, Shell, Saudi Aramco, GazProm, a Statoil norueguesa, a brasileira Petrobrás, as estatais de mineração de carvão de países como a China, a Rússia, a Polônia... Em seguida, nomes como Monsanto, Dupont, Syngenta, Bayer, Cargill, Bunge, Dow, a "nossa" Vale, Rio Tinto, Nestlé, as empresas dos sinistros Irmãos Koch e muitas outras também merecem destaque, por suas variadas contribuições para a conversão do "mononaturalismo" cosmológico dos Modernos em uma mega-economia agrícola de monoculturas, para a perturbação duradoura dos ciclos geoquímicos dos solos e das águas, para a colossal poluição ambiental, para a disseminação de alimentos danosos à saúde humana... Atentemos ainda para a lista dos 147 bancos e demais corporações conectadas em uma super-rede tentacular que envolve o planeta em um abraço mortal (Coghlan \& MacKenzie 2011)... E não esqueçamos de incluir os governos de países como o Canadá, a Austrália, os Estados Unidos, o Brasil e vários outros que vêm estimulando práticas de extração de combustíveis e minérios de alto potencial contaminante, fazendo vista grossa 
para o desmatamento, barrando os rios, entravando as negociações em torno da catástrofe climática... A lista é longa, enfim, mas não é infinita (Danowski e Viveiros de Castro, 2017, p. 139-140).

Não se trata, dessa maneira, de nenhuma agência transcendente, fora do mundo ou de nenhum conceito abstrato como "a 'civilização', o 'progresso', a 'história', o 'destino' ou a 'humanidade'” (idem, p. 140) - mas de agências deste mundo, neste mundo, como empresas, conglomerados e Estados nacionais, e, por isso, situadas e contingentes (ainda que não pareçam):

As histórias sistêmicas de metabolismos ligados, articulações ou coproduções (escolham sua metáfora) de economias, de ecologias, de histórias e criaturas humanas e não-humanas, precisa ser implacavelmente oportunista e contingente. Devem ser também implacavelmente relacionais, simpoiéticas e consequentes. Elas são terrenas, não cósmicas ou abençoadas ou amaldiçoadas até o espaço sideral (Haraway, 2016b, p. 49).

O Capitaloceno, termo proposto pelo historiador e ecologista Jason Moore que Haraway prefere em lugar de Antropoceno por remeter ao capital que tanto concorre para sua efetuação ${ }^{104}$, “é terreno" (idem). Isso significa, ela continua, que ele "não tem que ser a última época geológica biodiversa que inclui a nossa espécie. Ainda há muitas histórias boas para serem contadas [...] e não só por seres humanos" (idem). Ora, que ainda haja histórias boas parece-me indubitável; menos certo é que essa época não precise "ser a última...", Ou antes, mesmo que não "precise", há a possibilidade real de que seja - se a temperatura aumentar demais ou se houver uma guerra nuclear, por exemplo. A possibilidade, aliás, de o clima continuar mudando depende apenas da manutenção ou não das atuais taxas de emissão de gases de efeito estufa. A espécie humana, toda ela, já habita um mundo com cada vez menos biodiversidade; mas nem ela nem a biodiversidade estão ainda acabadas. Aquilo para que a filósofa aponta, com seu lampejo de otimismo, "não tem que ser", é a contingência. Em A insustentável leveza do ser, o escritor Milan Kundera compara as anotações de Beethoven em seu "Quarteto de cordas n. 16", "Muß es sein? Es muß sein!" - "Deve ser assim? Deve ser assim!", à constatação de um dos personagens em relação à natureza de seu

104 Conforme ele explicou: "o Capitaloceno não denota o capitalismo como um sistema econômico e social.[...] Antes, o Capitaloceno significa capitalismo como um modo de organizar a natureza - como uma ecologia-mundial multiespecífica, situada e capitalista. [...] Tem havido muitos outros jogos de palavras - Antrobsceno (Parikka 2014), econoceno (Norgaard 2013), tecnoceno (Hornborg 2015) [...] Todos são úteis. Mas nenhum captura o padrão histórico básico da história mundial como 'Era do Capital' - e a era do capitalismo como uma ecologia-mundial de poder, capital e natureza (Moore, 2016, p. 6). 
primeiro amor: "Tomas [...] chegou à conclusão de que sua história de amor exemplificava não 'Es muß sein!', mas antes 'Es könnte auch anders sein' (poderia também ter sido de outro modo)" (Kundera, 1985, p. 35). Assim como o romance de Tomas, o Antropoceno é no e do mundo; tem-se então o direito de, à pergunta “deve ser assim?”, responder que "não deve ser assim!” Por outro lado, não há uma janela tão grande para que ainda possa ser "de outro modo." Haraway sabe disso, e não é ingênua a ponto de sustentar a viabilidade de uma salvação - já se foi longe demais na destruição, já há muito débito de extinção - ou de um retorno à Inocência e ao Éden, mas aquela mais humilde, e no entanto ainda fervilhante, "de recuperação parcial e prosseguimento em conjunto [getting on together]" (Haraway, 2016b, p. 10) que jaz no esforço de continuidade de produção e manutenção de conexões em um mundo cada vez mais danificado.

Um dos modos do cultivo de continuidade e recuperações privilegiados pela autora é o da prática de multiplicação de narrativas ou histórias [storytelling]. Não se trata, obviamente, dos "fatos alternativos" que hoje em dia intoxicam os debates políticos e são apenas sinônimo de mentira sórdida destinada a romper relações e articulações ${ }^{105}$, mas, de modo oposto, do empenho em criar e dar prosseguimento a relações e articulações multiespecíficas situadas em práticas mundanas. Em Extinction Studies, a antropóloga Deborah Bird Rose, o filósofo Thom van Dooren e o pesquisador de humanidades ambientais Matthew Chrulew asseveram que pensar a extinção em massa

Frequentemente nos leva à consideração das temporalidades: desde o tempo profundo dos processos de evolução e especiação até o ritmo assustadoramente rápido no qual a perda de biodiversidade acontece hoje. Os modos pelos quais espécies particulares fazem suas vidas dependem de sincronias características e

105 A expressão foi cunhada por Kellyanne Conway, conselheira do presidente norteamericano Donald Trump, em janeiro de 2017, para justificar uma afirmação falsa cometida por ela em relação ao número de participantes na posse de Trump. Desde então, o termo vem sendo usado criticamente para se referir aos abundantes discursos que deturpam e adulteram dados e fatos sobretudo com o propósito de propaganda ideológica, de um modo parecido com o da "novafala" do romance distópico 1984, de George Orwell (cf. Seaton, Crook e Taylor, 2017, s/p): "O objetivo da Novafala não era somente fornecer um meio de expressão compatível com a visão de mundo e os hábitos mentais dos adeptos do Socing [o partido político no poder], mas também inviabilizar todas as outras formas de pensamento. A ideia era que, uma vez definitivamente adotada a Novafala e esquecida a Velhafala, um pensamento herege — isto é, um pensamento que divergisse dos princípios do Socing — fosse literalmente impensável, ao menos na medida em que pensamentos dependem de palavras para ser formulados" (Orwell, 2009, p. 348). A ideia de fatos alternativos se aproxima daquilo que Latour chama de "relativismo absoluto": "O relativismo absoluto supõe culturas separadas e incomensuráveis" (Latour, 1993, p. 102), metafisicamente isoladas; nesse sentido, eles rompem com qualquer articulação, não só com aquilo que se chama realidade, como com qualquer outra perspectiva. Trata-se, afinal, de um ponto de vista desconectado e totalitário que pretende erigir, de modo imperial, um mundo sem mais ninguém. 
frequentemente frágeis e temporalidades entrelaçadas cada vez mais interrompidas por uma espécie "fora do tempo", que persegue lucros a curto prazo ou produz produtos quase-imortais [...]. Contudo, os modos pelos quais podemos estudar e, de fato, tentar combater a extinção levam também às múltiplas temporalidades das narrativas [storytelling], tentativas criativas de produzir novos modos de compreender e se relacionar com o tempo, de medir e contar o tempo, de tomar tempo [taking time] - nosso e deles - e de devolvê-lo às criaturas prematuramente privadas do tempo de que precisam para preparar suas próprias gerações resilientes, a encarar suas próprias mortes frutíferas (Rose, van Dooren e Chrulew, 2017, p. 356).

Assim, a Sexta Extinção diz respeito também à imposição de um tempo sobre os demais. A destruição acelerada força sobre outras espécies uma temporalidade que lhes rouba o tempo necessário para produzir e reproduzir suas gerações, seus mundos, entregando-lhes apenas o "Tempo do Fim”, como o débito de extinção: "o tempo está fora do eixo, e andando cada vez mais rápido" (Danowski e Viveiros de Castro, 2017, p. 23), também para as outras espécies. A Sexta Extinção também é um ataque, como disse Rose, simultaneamente à vida e à morte (cf. Rose, 2006). À vida, claro, porque esta desaparece; mas também à morte, porque ela compõe a vida, sendo necessária para a sua continuidade. As extinções pervertem a morte na medida em que roubam seu sentido, devolvendo à vida uma versão da morte incapaz de fazer a conexão entre espécies e gerações: corpos mortos cedo demais, envenenados demais, inábeis para reproduzir e recompor. Margulis e Sagan, em algumas das respostas à questão "o que é vida?", de seu livro homônimo, diziam que ela é "um padrão intricado de crescimento e morte, pressa e recuo, transformação e decadência” (Margulis e Sagan, 2002, p. 66); que ela, "preservando o passado e estabelecendo uma diferença entre o passado e o presente, [...] vincula o tempo ampliando a complexidade e criando novos problemas para si mesma" (idem, p. 97). O que a extinção em massa barra é essa mestria vinculadora; em vez de um "caos artístico controlado" (idem, p. 44), a vida se torna serva de um tempo único e veloz que não comporta mais a duração de suas experiências.

Abrir as portas para a emergência de narrativas cujas temporalidades não se confundam com o acelerado tempo do fim, mas que irrompam por dentro dele e criem sensibilidades e conexões, fazendo despontar novos passados, presentes e futuros, pode ser um modo de freá-lo ou, pelo menos, de honrar os mundos perdidos. Isso pode parecer muito pouco - contar histórias - "à sombra de toda essa morte" (cf. Rose, 2013), mas só seria o caso se as histórias fossem 
consideradas também como fora do mundo. Elas, entretanto, não só são do e no mundo como fazem mundos, rearticulando passados, presentes e apontando para outros futuros.

"Importam as histórias com as quais contamos histórias [...] Importam quais histórias fazem mundos, quais mundos fazem histórias" (Haraway, 2016b, p. 12). Advindas de uma miríade de lugares diferentes, como mitos, artes, ciências naturais e humanas, filosofia e outros, elas efetivamente compõem processos de mundificação. A história de como a Prometeu e Epimeteu foi dada a tarefa de distribuir qualidades aos animais, o que eles fizeram com uma prodigalidade tal que não sobrou nada para o homem, levando Prometeu a roubar as artes e o fogo dos deuses para presenteá-lo aos homens; a história de como só (alguns) homens possuem alma; de como alguns homens são mais propriamente humanos que outros; de como os homens são superiores às mulheres; de como certos deuses e mundos são mais reais que outros; de como a natureza é muda e mero recurso; e todas as histórias da humanidade excepcional em suas variações de animal universal, povo exclusivo ou eleito, única espécie a possuir discurso, política, história, ferramentas e até mãos são todas modos de constituir (e destituir) mundos. Elas são, finalmente, parte da história que culmina no Antropoceno. Se não formos cuidadosos, elas podem indicar também que não há nada fora dessa nova história, que não há outros modos de estar no mundo e co-constituí-lo. Podem até fazer crer que o destino do homem (e do planeta) foi traçado em sua origem, que todos os seus dons e maldições levarão inexoravelmente à destruição.

Chega dessa história. O que Haraway, Rose, van Dooren, Chrulew e outros dedicados a pensar a extinção propõem é uma atitude de dedicação e cuidado diante de outras histórias - subterrâneas, marginais, criativas, menores no sentido deleuziano. É esse conjunto de histórias, de tudo o que permanece fluente e articulado entre criaturas humanas e outras que Haraway chama de Chthuluceno. Com esse nome, ela quer designar os "poderes tentaculares terrenos" que, embora “agravados por suas problemáticas radículas meio gregas, emaranham miríades de temporalidades e espacialidades e miríades de intra-ativas entidades-emagenciamentos - incluindo o mais-que-humano, o outro-que-humano, o inumano e o humano-como-húmus" (Haraway, 2016b, p. 101). Não um nome novo ou mais apropriado à época, o Chthuluceno é o que possibilita a irrupção, nela, de “inappropriate/d others" (outros inapropriados/impróprios), para usar um termo 
que a autora toma emprestado da cineasta e teórica Trinh T. Min-ha (cf. Haraway, 1992):

A frase de Trinh refere-se ao posicionamento histórico daqueles que não podem adotar a máscara de "si mesmo" [self $]$ nem a de "outro" oferecida pelas previamente dominantes narrativas ocidentais de identidade e política. Ser impróprio/inapropriado não significa "não estar em relação com", i.e., estar em uma reserva especial com o estatuto de autêntico, intocado, na consideração alotópica e alocrônica da inocência. Antes, ser um "outro impróprio/inapropriado" significa estar em relacionalidade desconstrutiva, crítica, em uma difração [...] como meio de fazer conexões potentes que excedam a dominação. [...] Trinh procurava um modo de figurar a "diferença" como uma "diferença crítica dentro" [...] (Haraway, 1992, p. 299).

Por sobre genocídios e entre miríades de fins e começos de mundo, o Chthuluceno é abertura da possibilidade de florescimentos parciais, difíceis e nãosalvacionistas com os outros:

Todos os mil nomes ${ }^{106}$ são grandes demais e muito pequenos; todas as histórias são grandes e pequenas demais. [...] Precisamos de histórias (e teorias) que sejam grandes o suficiente para reunir as complexidades e manter as bordas abertas e ávidas por conexões novas e velhas (Haraway, 2016b, p. 101).

A sigla SF proporciona, para a autora, modos potentes de irrupções de histórias do Chthuluceno; assim, ela se alia a pensadores das mais diversas áreas e artistas de outras tantas expressões para, com eles, aprender a pensar e promover o florescimento conjunto de histórias que convoquem práticas multiespecíficas de recuperação. Em seu Staying with the trouble. Making kin in the Cthulhucene, de 2016, Haraway foi inclusive além e, depois de 130 páginas de teoria, oferece uma história de cerca de 30 páginas que encena um possível futuro da América do Norte repleto de continuidades e mortes, no qual pessoas são modificadas geneticamente para se misturar a certos animais, como as ameaçadas borboletas monarcas (os animais permanecem inalterados). Nessa história, os "Filhos da Compostagem" [Children of Compost] tornam-se simbiontes de espécies em extinção, que elas não compreendem mais como outros que humanos, mas como "compost" e húmus. A autora narra cinco gerações dessa comunidade

\footnotetext{
${ }^{106}$ A expressão "Os mil nomes" faz referência ao Colóquio Internacional Os Mil Nomes de Gaia - Do Antropoceno à Idade da Terra, que aconteceu no Rio de Janeiro em 2014: "Os antropólogos e filósofos Eduardo Viveiros de Castro e Déborah Danowski exorcizam noções prolongadas de que Gaia está confinada aos gregos antigos e às subsequentes euroculturas em suas refigurações das urgências de nossos tempos na conferência pós-eurocêntrica 'Os Mil Nomes de Gaia'. Nomes, não rostos, não mutações do mesmo, alguma outra coisa, mil outras coisas, ainda contando sobre mundificações e remundificações fluentes, articuladas e gerativas nessa idade da terra. Precisamos de outra figura, mil nomes de outra coisa, para explodir para fora do Antropoceno em uma outra história, grande o suficiente" (Haraway, 2016b, p. 52)
} 
profundamente comprometida com a diminuição da população humana na Terra de um modo não totalitário (ter filhos se torna uma decisão coletiva, cada criança tem pelo menos três pais etc.). Cinco moças-borboletas chamadas Camille, então, vivem por entre períodos de agitação à medida que os efeitos da catástrofe se tornam cada vez mais evidentes. Mesmo que essas consequências sejam contrabalançadas por práticas imaginativas no seio de grupos empenhados em coerguer mundos possíveis e múltiplos, a salvação não está no horizonte. À altura do nascimento da quinta Camille, por exemplo, "muitos humanos são simbiontes de parceiros extintos" (Haraway, 2016b, p. 166). Nesse mundo cujas feridas nem sempre podem ser cicatrizadas, desenvolve-se uma tradição de "oradores dos mortos", cuja tarefa é "trazer os mortos ao presente, de modo a fazer a vida e a morte mais respons-áveis nos tempos por vir” (idem, p. 69).

A função de "orador dos mortos" é colhida pela autora da série de livros de ficção científica Ender's Game, do escritor Orson Scott Card, especialmende de seu segundo volume, Speaker for the Dead (cf. Card, 1994). Nesta saga, o humano Ender, após ter exercido um papel fundamental na derrota das Formics, espécie alienígena similar às formigas, escreve um tipo de eulogia contando a história desse povo sob o pseudônimo de "orador dos mortos." A publicação dessa obra faz com que os humanos deixem de sentir ódio pela espécie destruída e passem a experimentar a tristeza e o luto do que compreendem ter sido um "zenocídio" (a aniquilação de uma espécie alienígena) -, o que transforma Ender de salvador dos humanos em zenocida. Ender, entretanto, mantém um segredo: carrega consigo uma rainha dormente, que ele em algum momento leva até um planeta determinado de modo a dar àquele povo a chance de uma nova vida. Falar dos mortos leva a uma metamorfose de Ender e do mundo: de Ender, porque ele deixa de ser o herói destruidor não apenas diante da opinião pública, mas para si mesmo, distanciando-se de seu passado militar - abandonando inclusive o apelido Ender para se referir a si mesmo como Andrew; do mundo, pois se deixa de considerar o assassinato de uma espécie como uma vitória, passando a experimentá-la como zenocídio. Nestas histórias, tanto Ender quanto as Formics ganham uma nova oportunidade de vida, ele como Andrew, elas em outro planeta. Talvez a humanidade investida na extinção também consiga se transformar em humanidade investida na continuação; para as espécies desaparecidas, por outro lado, essa possibilidade não existe mais. $\mathrm{O}$ ato de falar dos mortos e diante deles, 
entretanto, pode ser transformativo; dos mortos, com quem se faz aliança, e que passam a ser compreendidos como vítimas de um ataque, por exemplo; dos vivos presentes que, articulando-se com esses novos passados, têm a chance de agir diferentemente; dos possíveis vivos futuros, cuja existência depende de compromissos firmados em seu passado. Não é pouca coisa a promessa de prosseguimento que essa prática encerra, e parece que é aí que Haraway aposta suas fichas com suas "Camille stories", que se beneficiam de imaginações literárias e do arcabouço teórico de Haraway corporificado em personagens. Nesse sentido, elas são um exercício de trazer ao presente um outro futuro possível, tornar este presente o passado de um futuro no qual o mundo, ainda que deteriorado, continua a ser o resultado de experimentações de devir-com multiespecíficas.

Van Dooren escreveu o artigo "Spectral Crows in Hawai'i" depois de visitar a maior ilha do arquipélago homônimo no Pacífico com o objetivo de conhecer os projetos de conservação do Corvus hawaiiensis, corvo-havaiano ou alala. Esta espécie, hoje desaparecida da natureza, se agarra ao mundo através dos cerca de 100 indivíduos remanescentes que vivem nas instalações desses projetos. Seu esvanecimento está ligado à diminuição das florestas nativas, que o alala se recusou a abandonar, não tendo jamais se adaptado a outros ambientes. Fiéis ao seu mundo, foram diminuindo junto com ele; as florestas, por sua vez, mesmo as áreas protegidas, agonizam hoje por terem perdido um de seus principais polinizadores: restaram apenas "corvos espectrais assombrando uma floresta moribunda" (van Dooren, 2017, p. 3239). A história que van Dooren conta é uma na qual, no Hawai'i, os conservacionistas e a população nem sempre se dão bem. Um projeto destinado a preservar as matas nativas, que inclui a construção de cercas para manter à distância populações de porcos que a degradam, foi recebido não apenas com desconfiança, mas com contrariedade profunda por parte dos caçadores nativos, que se sentem roubados, mais uma vez de seu modo de vida. Em sua defesa, eles se referem à história do Grande Māhele, de 1848, quando, sob o pretexto de redistribuição, foi executado um enorme processo de usurpação de terras dos povos nativos, leiloadas em benefício de conglomerados norteamericanos. Essa história torna claro também o problema das propriedades privadas, terras que um dia pertenceram aos nativos, nas quais eles não têm permissão para caçar - mesmo as terras estatais, o autor explica, têm uma 
porcentagem mínima destinada tanto à caça quanto à preservação. Enquanto os conservacionistas contam histórias sobre a importância do alala em si mesmo, parte dos povos nativos não se comove - e passa a considerar o corvo um inimigo, já que sua volta às florestas, significando cercas, acenaria para novas usurpações. Mas há também outras histórias: a de como os porcos não viveram sempre nas florestas, mas se mantinham nas proximidades de comunidades humanas; ou a de como o alala é parte do conjunto de histórias que produziram e produzem os mundos dos povos do Hawai'i. A continuidade (ou não) desta espécie de corvo, portanto, encontra-se atravessada por diversas histórias - de acordos escusos entre governos com o propósito do roubo de terras, mas também de ancestrais e fluentes mundificações multiespecíficas naquelas mesmas terras.

Há também, é claro, as histórias do alala: aquela de como sua co-evolução com a floresta faz com que a sua extinção seja também a dela, em um codesaparecimento ("a coevolução pode virar coextinção; o co-devir, padrões emaranhados de morrer-com", idem, p. 3297); a de como "as plantas chamam o alala, seus corpos frutíferos e florescentes modelados por atrações e associações passadas que não existem mais" (idem, p. 3281); aquela da perda de seu repertório vocal no confinamento dos projetos de conservação, no qual "eles têm menos sobre o que conversar, ou talvez os pássaros juvenis não tenham sido expostos suficientemente ao falatório dos mais velhos" (idem, p. 3550); ou a de como, ainda chamados pelas plantas, muitos, por terem vivido longe das florestas, não as conhecem com a mesma destreza, ou a destreza cuja existência sequer chegaram a suspeitar, aquela sobre os predadores; além de todas as histórias secretas, que eles urdiram com seus companheiros alala e outros, por tanto tempo, dentro das florestas. Todas essas histórias se encontram entrelaçadas, compondo presentes e passados; para que haja futuro para algumas delas, é preciso decidir quais herdar, a quais se aliançar. Essas decisões não são simples nem inocentes e dependem da força que se consagra a cada história. Um dos discursos que van Dooren cita é o de uma mulher nativa:

Profundamente comprometida com a soberania havaiana e que trabalhava para o governo como bióloga. Quando lhe perguntavam sobre a incompatibilidade entre sua política e seu emprego, [...] ela dizia que estava conservando a diversidade biótica do Hawai'i de modo que, quando a soberania viesse, o povo e a terra estivessem na melhor condição para isso (idem, p. 3506). 
Esse talvez seja um modo de habitar o problema - criar uma nova história que traga consigo histórias antigas aspirando a fluentes e articulados futuros. Van Dooren encerra o texto fazendo uma exortação que valoriza o papel das histórias criadoras e sustentadoras de mundos durante a Sexta Extinção:

O nosso tempo é um de extinções em massa, um tempo de colonização contínua de uma diversidade de vidas humanas e não-humanas. Mas também é um tempo que mantém a promessa de muitas frágeis formas de descolonização e esperanças em uma justiça ambiental duradoura. Aqui, o trabalho de manter aberto o futuro e herdar responsavelmente o passado requer novas formas de atenção a diversidades bioculturais e seus muitos fantasmas. Mas para além de simplesmente ouvir, também requer assumir o trabalho carregado - nunca terminado, nunca inocente de tecer novas histórias dessa multiplicidade. Histórias dentro de histórias que reúnam a diversidade de vozes necessárias para habitar responsavelmente os ricos padrões de herança entrelaçada que constituem nosso mundo (idem, p. 3563).

\section{5 . \\ Sangue e vísceras}

Rose costuma contar uma história que lhe foi transmitida por um aborígene na Austrália, Old Tim Yilngayarri: "Havia um homem que atirava em cães e ele está morto agora" (Old Tim Yilngayarri apud Rose, 2011 p. 201,3). Os "cachorros" a que o velho Tim se referia são dingos, os caninos selvagens que vivem na Austrália há cerca de quatro ou cinco mil anos, mantêm relação com povos locais e encontram-se sob a classificação de espécie vulnerável na lista da IUCN, com suas populações em tendência decrescente, mas contra os quais Estado e agronegócio declararam guerra, sob a justificativa de que eles predam o gado. Além da prática, ainda em voga, de recompensas por suas cabeças e do lançamento, por aviões, em iniciativa governamentais, de iscas envenenadas contra eles, existe no país uma cerca "anti-dingo" de 5.400 km, "um Muro de Berlim ecológico comparável à Grande Muralha da China" (Woodford apud Rose, 2011, 157,7). Assim como não são apenas os dingos que morrem envenenados pelas iscas, mas todos aqueles que as ingerem ou se alimentam dos corpos mortos pelo veneno, a cerca também impede a passagem de muitas outras espécies animais, como cangurus, emus e camelos, que perecem - de sede, por exemplo -, por não conseguir atravessá-la. Outra prática consiste em pendurar na cerca carne envenenada, muitas vezes a carne dessas vítimas colaterais, ou, alternativamente, expor as carcaças dos próprios dingos mortos, também ao longo da cerca ou em “porteiras, árvores e postes" (Rose, 2011, p. 160,5). Rose relata ainda a existência 
de portões no perímetro da cerca, ao lado dos quais veem-se placas ameaçando com multas quem as deixar abertas, tudo administrado pela "Wild Dog Destruction Board," agência estatal fundada em 1921 e que hoje se dedica à sua manutenção. Ela conta também a história de como, durante as décadas de 1920 e 1930, o governo australiano pagava por escalpos de dingos, prática que garantia o sustento de diversos colonos e aborígenes. E aquela outra, de como, por volta da década de 1940, os dingos eram tratados como substitutos dos aborígenes no exercício da violência policial, sendo comum a prática da invasão, por parte de agentes do Estado, de comunidades aborígenes para matar os animais que viviam com os povos locais; a autora recupera um desses relatos, escrito por dois antropólogos que recolheram histórias e compuseram uma narrativa:

"Polícia! Polícia!" O grito ressoou espavorido através do campo. Eles o haviam visto chegar, mas já era tarde demais para correr com seus melhores cães até a segurança entre os arbustos... Freneticamente, tentavam agrupar seus cães favoritos dentro das cabanas. E algumas almas otimistas saíram correndo para o mato, segurando alguns cães na ponta de longas coleiras, enquanto outros corriam junto deles. M. C. Gruppy sorriu cruelmente para si mesmo: boa aquisição aqui, os mendigos devem tê-los reproduzido desde a última vez. Ele levantou seu rifle e avistou as figuras que fugiam.

Aí foi um pandemônio. Enquanto as balas voavam, as mulheres gritavam de medo, arrastando seus animais ainda mais rapidamente atrás delas. Um cachorro ganiu subitamente, pulou no ar e rolou chutando na poeira. Outro se seguiu, e outro. Um, coxeando ferido no ombro, era um alvo fácil; seu corpo caindo na coleira, atrasando sua chorosa dona por um segundo antes de ela largar a guia e fugir ofegante...

Um grupo de velhas se agachou atrás de um arbusto, com um precioso kangaroo dog escondido entre elas debaixo de um cobertor. Mas os policiais sabiam tudo sobre esses truques. Sua bala varou o cobertor até a vítima, chamuscando o cabelo branco de uma de suas guardiãs, de modo que elas se espalharam com um terror cheio de gritos...[...]

Cachorros trotavam em todas a direções para fora do campo. Bons, ruins e indiferentes, aqueles que eram valiosos para a caça, aqueles que eram só medíocres, e aqueles que eram um incômodo de fato; não fazia diferença. Eram todos cães, e todos igualmente deveriam cair ante a chuva de balas.

Finalmente, ele baixou seu rifle e olhou ao redor. Nenhum cachorro no campo agora, só um bando de crioulos [niggers] borrados de medo. Faz bem a eles, mostrar-lhes o que um policial pode fazer se quiser: bando de inúteis imprestáveis (Berndt apud Rose, 2011, p. 64,4).

"Para gente que já tinha sido submetida a massacres, atirar em cães era uma clara mensagem sobre o direito de matar com impunidade", comenta Rose (Rose, 2011, p. 65,9), lembrando ainda da "porosidade da fronteira humano-animal no Ocidente", que opera a animalização de populações para que elas possam ser assassinadas sem que se cometa um crime - sem contar o fato de que, além de espécies animais, a destruição atual também se estende a línguas, povos e modos 
de vida humanos. Segundo ela, entretanto, quando o velho Tim, que testemunhou massacres como esse, contava a história sobre o homem que atirava em cães e morreu, ele não exprimia um desejo de vingança, senão uma mera constatação: se você faz isso, então aquilo se sucederá. Se você destrói as conexões que amparam a vida, não pode esperar mais nada além de morte para si e para os seus.

Lévi-Strauss, em um artigo chamado "A lição de sabedoria das vacas loucas", refletiu sobre a epidemia de Encefalopatia Espongiforme Bovina, surgida devido ao canibalismo a que o gado é forçado ao receber como alimento uma ração composta de, entre outras coisas, carne, ossos, sangue e vísceras de outros animais da mesma espécie. Ele sugeriu que a expansão da população humana que só em seu período de vida passou de 1,65 bilhão para 6,7 bilhões - tornaria impossível a continuação do consumo de carne no mesmo nível que se observava em 1996, época da escrita do artigo. Uma alimentação quase vegetariana, que ocupa menos espaço e requer muito menos recursos que a produção de carne, viria a se tornar a regra, a carne se tornando, segundo ele, artigo de luxo. Com esse exemplo, o antropólogo queria dizer que o crescimento contínuo das sociedades modernas seria o principal causador de sua ruptura: face aos limites planetários, ela seria obrigada a recuar:

Não se pode afirmar que a expansão de uma civilização que se pretende mundial uniformizará o planeta. Amontoando-se como hoje em megalópoles tão grandes quanto regiões inteiras, uma população terá evacuado outros espaços. Definitivamente abandonados por seus habitantes, tais espaços retornarão às suas condições arcaicas: aqui e ali surgirão as mais estranhas formas de vida. Em vez de caminhar em direção à uniformidade, a evolução da humanidade acentuará os contrastes, criando o novo e restabelecendo o reino da diversidade. Romper hábitos milenares - essa é talvez a lição de sabedoria que um dia haveremos de aprender com as vacas loucas (Lévi-Strauss, 2009, p. 84).

Uma civilização baseada em uma expansão sem limites não tem futuro em um planeta finito. $\mathrm{O}$ autor provavelmente estava sendo muito otimista ao acreditar na história de que o colapso teria por consequência a criação do novo e o reestabelecimento do reino da diversidade, tanto mais que a indústria da carne parece empenhada em destruir até o último ecossistema para criar áreas de pasto e monocultura para alimentação do gado. É muito mais possível que, continuando no mesmo passo, o futuro nos ${ }^{107}$ reserve, contrariamente, um reino de

107 Ainda que tenha nomeado as agências da destruição, fazendo questão de não responsabilizar toda a humanidade pelo Antropoceno, é irresistível, de dentro de minha pequena unidade de habitação familiar, diante do mundo domesticado que me cerca, dizer "nós". Sem a 
precariedade e pobreza, ou pior, o anti-reino do fim do tempo. Mas talvez ainda haja tempo, dependendo das histórias que escolhermos e pudermos escolher para fazer mundos, de desenhar futuros menos sinistros.

Margulis e Sagan diziam que "os animais são tão assombrosos que, como seres humanos, não precisamos considerar-nos nada além de animais para nos sentirmos justificadamente orgulhosos" (Margulis e Sagan, 2002, p. 160). A história desta civilização colonizadora e em eterna expansão, contudo, vem tentando há muito tempo denegar seu pertencimento à animalidade e mesmo ao mundo, atitude que fomenta histórias de extinções e massacres. Com esta denegação, o que se contraria é a vida ela mesma, que também é

a exuberância evolutiva; [...] o que acontece quando populações crescentes de organismos sensíveis e atuantes esbarram umas nas outras e elaboram coisas. A vida é a brincadeira dos animais. [...] a maravilha das invenções para esfriar e aquecer; colher e espalhar; comer e fugir; cortejar e enganar. A vida é ciência e reatividade; é consciência, e até autoconsciência. A vida, contingência histórica e curiosidade matreira, é a nadadeira agitada e as asa desejante da engenhosidade dos animais, a vanguarda da biosfera interligada cujo epítome são os membros do reino animal (idem, p. 179).

Se haverá alguma lição a ser aprendida, como desejava Lévi-Strauss, é algo a se ver. O fato é que, ao precipitar a Sexta Extinção, esta civilização abriu as portas para histórias de horror profundo que aterrorizam também ela mesma. Enquanto enterravam seus cães, assassinados pelo Estado, os aborígenes com quem Rose conversou, ela imagina:

Estavam olhando para o vazio que costumavam ser cães, e esse vazio não era uma partida do que costumava ser torcido de volta em direção à vida, mas antes uma viagem sem volta em direção ao nada. Esse vazio carregava uma mensagem: podia haver outro vazio, um que costumava ser gente. E, enquanto as pessoas choravam por seus cães, talvez não sobrasse ninguém para chorar por elas (Rose, 2011, p. $65,9)$.

No caso dessas pessoas, não sobrar ninguém queria dizer que todos teriam sido mortos, todos com quem eles haviam constituído mundos. No daqueles que os colocaram, junto com uma imensidade de outros seres, em uma situação de vulnerabilidade enquanto alimentavam delírios de singularidade, o que se passa é outra coisa. Como vaticinou Despret, "nenhuma espécie fará luto por nós podemos ter certeza disso - e, de fato, essa deve ser a nossa única reivindicação de excepcionalismo" (Despret, 2013, s/p). 
Quanto aos que por tanto tempo cultivaram e inventaram modos de habitar a terra, com ela e uns com os outros, agentes da exuberância e da continuidade iterativamente diferente - hoje extintos, assassinados, massacrados e aviltados -, que se repita, diante deles e sem jamais esquecê-los, à guisa de oração fúnebre, a mensagem da criatura de Kafka: o teu "sangue se infiltra neste chão e não se perde" (Kafka, 2002, p. 83).

Então, o que é política? É o desejo da vida, em suas aventuras e experiências de diferença, mistura, morte, descontinuidade e continuidade; é contar, herdar, abandonar e criar histórias que articulam passados, presentes e futuros novos; é um espaço cheio de sangue e fantasmas; é aliança e fluência por entre escombros; é a invenção e a sustentação do mundo por seus seres; não é a barragem de fluxos; não é a uniformização do planeta; não é, definitivamente, provocar o desaparecimento em massa de outros povos e espécies. A extinção é o seu aniquilamento. 


\section{6 \\ Conclusão}

A mudança necessária é de tal forma profunda que se diz que ela é impossível. De tal forma profunda que se diz que ela é inimaginável. Mas o impossível está por vir. E o inimaginável nos é devido. O que era mais impossível e mais inimaginável, a escravidão ou o fim da escravidão? $O$ tempo do animalismo é aquele do impossível e do inimaginável. Ele é o nosso tempo: o único que nos resta.

Paul B. Preciado, "Le féminisme n'est pas um humanisme"

Ao longo desta tese, procurei, por entre situações multiespecíficas, delinear alguns semblantes de políticas animais ou com os animais. Talvez a primeira conclusão, a mais óbvia e que no entanto permaneceu por tantas vezes oculta, é que essas políticas existem, em ato e em potência. Ninguém contestaria a afirmação de que não existe política para apenas um; mesmo assim, em grande parte dos discursos políticos, filosóficos ou não, encontra-se a pretensão de que ela diz respeito a uma só espécie, o Homo sapiens, ou a um só povo, o daqueles que se chamaram propriamente de Homens. Para fazer política, segundo eles, é preciso possuir um dom singular e exclusivo - encarnado com excelência pelas diferentes acepções de lógos e suas variações históricas - que permitiria apenas aos homens conhecer a Justiça, o Bem, tomar decisões informadas ou agir de acordo com uma finalidade comum. Somente pela propriedade desse diferencial, essencial ou adquirido, mundos poderiam ser construídos, comunidades de fato erigidas, relações políticas travadas. Le Guin, em trecho de um ensaio sobre animais na literatura infantil que figura na epígrafe deste trabalho, lançava uma provocação:

Deus na Bíblia diz: "Que se faça a luz." Somente nós, humanos, de acordo com aquela bíblia, somos à imagem de Deus. Então apenas Deus e Nós podemos dizer: "Que se faça a luz." Mas eu lhes pergunto, o que um galo às quatro da manhã está dizendo? (Le Guin, 2009, p. 55).

O que a biota terrestre está fazendo quando, por sua interação entre si e com entes físicos, constitui o sistema biogeofísico conhecido como Gaia? O que os chimpanzés no zoológico de Burgers estão fazendo quando se aliam ou se traem? $\mathrm{O}$ que fazem os lobos quando brincam entre si, inventando, negociando e 
aceitando (ou não) os termos do jogo, e aprendendo, assim, a agir de maneira justa? O que fazem as formigas escravizadas quando sabotam os ovos e pupas de suas captoras? O que fazia Hans Esperto enquanto ensinava seus parceiros de jogo a se mover de forma que ele acertasse as perguntas que lhe eram feitas?

A política está no mundo, ela é do mundo, não se ergue a partir dele por um poder mágico. Ela é o conjunto de modos de habitar e fazer mundos, de mantê-los de pé; é o devir-com das criaturas. E não se faz isso só, individualmente; uma comunidade ou uma cidade são o resultado de múltiplas relações travadas por diferentes entes, orgânicos e inorgânicos. Uma das lições que o Antropoceno ensina é aquela a respeito das consequências catastróficas de se considerar esses outros entes como meros recursos. Política é, portanto, geopolítica (não no sentido de estratégias de gerenciamento no âmbito dos Estados Nacionais em relação uns aos outros, de seus territórios compreendidos como uma coleção de recursos e condições materiais, mas de política da terra), teriopolítica, fitopolítica; em uma palavra, é cosmopolítica. A máxima de Aristóteles, portanto, deveria ser reescrita: o homem, por natureza um animal, é político.

Por outro lado, quando age segundo a crença de que faz parte de uma raça eleita, quando ergue a cidadela da exceção ontológica, recusando aos outros suas vozes e agências e comportando-se como administrador do planeta, o que o homem faz é matar a política. As extinções em massa, a gerência torturadora da vida e da morte em laboratórios e complexos de produção animal e o controle de populações por meio do regime de extermínio, entre outros, não são apenas bio ou necropolítica - termos que, ademais, costumam dizer respeito somente a humanos -, mas aniquilação da política enquanto tal. Segundo Agamben, para quem não existe uma vida política dos animais, não é possível uma ação "verdadeiramente política" no estado de exceção (cf. Agamben, 2004, p. 133), que seria marcado por uma "pura violência sem lógos" (idem, p. 63). Para os animais, seria fácil concluir que não pode haver ação política no estado de exceção ontológico a que são submetidos; contrariamente ao que afirmava o filósofo, entretanto, a marca desse estado seria uma pura violência do lógos.

Há saídas, entretanto, e elas continuam sendo percorridas por arranjos multiespecíficos que podem ou não envolver humanos. A política animal ou dos animais, que existe, se faz atualmente nos interstícios da grande máquina Humana, o conjunto de histórias maiores conhecido como Antropoceno. 
"Vivemos sozinhas ou acompanhadas nas frestas de seu mundo-máquina" (Tiptree Jr, 2014, p. 134), dizia a senhora Parsons, personagem do conto "The Women Men Don't See", que Alice Sheldon, sob o pseudômino James Tiptree Jr, escreveu, referindo-se ao modo de existência das mulheres no mundo masculino. Quando seu interlocutor lhe responde que isso se parece com a forma guerrilha, ela the pede que "pense em nós como gambás, Don. Você sabia que há gambás vivendo por toda a parte? Até na cidade de Nova York" (idem). Tiptree, por meio da senhora Parsons, intencionalmente aproxima o mundo dos homens à máquina uma máquina em cujas engrenagens, entretanto, se amontoam gambás, animais “por toda a parte." Esta talvez seja uma imagem condizente com a situação das minorias - a de bandos de espécies outras que humanas habitando frestas, mas com o acréscimo de que são fundamentais para o funcionamento dessa máquina. Nessas fissuras, fendas, buracos e tocas não se vive sempre do mesmo jeito; tais zonas são diferentemente marcadas e experimentadas, e dependem de uma série de fatores contingentes que passam pelo entrelaçamento de disposições espirituais e possibilidades materiais.

Costello, que considera a relação entre animais humanos e outros que humanos como uma de guerra dos primeiros contra os segundos, escravizados como prisioneiros, lembra que esta configuração é recebida multiplamente. Há, por exemplo, mesmo no seio da domesticação uniformizante, os bichos que resistem:

Mas ainda existem animais que odiamos, como os ratos, que não se renderam. Eles reagem, se organizam em unidades subterrâneas em nossos esgotos. Não estão vencendo, mas também não estão perdendo. Sem falar dos insetos e micróbios, que podem nos vencer e certamente sobreviverão a nós (Coetzee, 2009, p. 71).

Resistência, ou rexistência, para usar um termo empregado por Viveiros de Castro (2016) no contexto da luta das populações indígenas atacadas pelo Estado brasileiro, é também uma das maneiras pelas quais politicamente os animais se mantêm no mundo e refazem seus mundos. Resistir, entretanto, não é necessariamente guerrear, sobretudo se se entende a guerra segundo o conceito schmittiano (cf. Schmitt, 2006), e não segundo outras concepções, como a da "guerra contra o Estado" ou a guerra praticada por sociedades indígenas, cujo fim não é o extermínio do outro (cf. Viveiros de Castro, 2002; Clastres, 2011; Romero, 2015). Diferentemente daquela ideia de guerra, resistência pode significar o conjunto de estratégias desenvolvidas pelos golpeados, uma espécie 
de contra-guerra cujo fim último não é o extermínio de corpos ou de modos de vida, mas a criação de linhas de continuidade, também um modo profundamente relacional de habitação do mundo - que depende, para sua implementação, de se considerar quanto, como e às custas de quem se pode resistir. Nesse sentido, seria injusto afirmar que os ratos resistem, mas que as vacas e as porcas, ou mesmo as espécies à beira da extinção, não. Há, por toda parte, redes de resistência mais ou menos subterrâneas compostas por grupos mais ou menos numerosos. Há as redes dos ratos nos esgotos, adaptando-se como podem ao mundo que insistentemente engloba o deles; há as redes dos projetos de conservação, compostas por humanos e outros que humanos, das quais emergem novas comunidades nas quais as competências subjetivas são redistribuídas, com novos atores e sujeitos emergindo nelas e delas; há as alianças entre os chamados "protetores" com os bichos citadinos errantes, ou aquelas de grupos como a Animal Liberation Front (cf. Animal Liberation Front, S/d), que libertam animais de laboratórios de pesquisa e outras situações cruéis (não se pode subestimar a influência dos bichos nessas ações, sua habilidade de afetar e atrair aqueles que, por sua vez, se abrem a eles); há também os bandos de cães, como aqueles que, abandonados na Floresta da Tijuca, no Rio de Janeiro, deixaram de ser pets e descobriram juntos uma sociedade sem humanos, constituindo-se em grupos "ferais" (cf. Azevedo, 2016); há mesmo a rede dos corvos-do-havaí, que se recusaram a abandonar a sua floresta, preferindo desaparecer com ela a se adaptar à civilização; e muitas outras, em espaços urbanos, rurais e selvagens. Na guerra que certos humanos declararam contra eles, os animais e seus aliados não cessam de rexistir.

Rose, em artigo sobre as quatro principais espécies de raposas-voadoras que vivem na Austrália (Pteropus alecto, P. poliocephalus, P. scapulatus, P. conspicillatus), conta parte das histórias em que elas se encontram emaranhadas (cf. Rose, 2011a). Esses morcegos, que se alimentam de frutas e são importantes dispersores de sementes, têm apenas um filho por ano e são altamente sociáveis, enfrentam uma miríade de ameaças de origem antropocênica, como perseguições, eventos climáticos extremos que os matam de sede e degradação de seus habitats - que os levam a procurar alimento em áreas mais próximas do solo, tornando-os vulneráveis à paralisia do carrapato, os matam envenenados por chumbo ou os conduzem até áreas urbanas onde podem ser assassinados a tiro ou em cercas eletrificadas, entre outros perigos. Em 1929, a antropóloga conta, o biólogo 
Francis Ratcliff foi designado para resolver o problema que as raposas-voadoras criavam para os cultivadores de árvores frutíferas; tendo concluído pela impossibilidade do extermínio dos animais, ele notou, entretanto, que "suas populações pareciam estar em declínio bastante rápido; portanto parecia possível que o problema se resolvesse por si mesmo" (Rose, 2011a, p. 126). Mesmo assim, ela nota, Ratcliff usava, para descrever "sua missão" (idem, p. 129), o vocabulário da guerra:

Quando um comandante militar planeja uma ofensiva, ele deve possuir certas informações com as quais trabalhar. Ele precisa saber, por exemplo, o tamanho e a potência das forças inimigas e as táticas que elas empregarão. Do mesmo modo, antes que uma campanha seja inaugurada contra um inimigo animal, é essencial possuir conhecimento preciso sobre seus números e hábitos (Ratcliff apud Rose, 2011a, p. 129-130).

De acordo com essa disposição militar, ele também avaliou os métodos utilizados no controle e extermínio dos morcegos, elencando-os segundo sua eficácia, além de sugerir modificações em práticas correntes com vistas ao sucesso da campanha contra esses animais:

Doenças introduzidas - quase nenhuma chance de sucesso [...] Recompensa por escalpos - custa mais do que os danos causados pelas raposas-voadoras; método menos eficaz [...] Gases venenosos (cloro, cianeto de hidrogênio) nos campos ineficaz [...] Explosivos - 'fracassos completos', mas podem ser úteis se o método fosse descarga de estilhaços [...] Lança-chamas - custoso, poderia ser rejeitado sob o fundamento de que é cruel [...] Tiros - se organizado e mantido por um certo número de anos, pode ter um 'efeito benéfico', particularmente se as 'fêmeas carregando filhotes' fossem o alvo [...] Iscas de veneno/estricnina - 'vale bem o trabalho' em certos pomares (idem, p. 130).

"A batalha contra as raposas-voadoras nunca envolveu semelhantes" (idem), observa Rose. Trata-se de uma guerra declarada por um Estado nacional, com todas as forças que ele pode mobilizar, contra uma espécie que, conforme dizíamos, pode se constituir por um povo ou conjunto de povos que não são, por sua parte, organizados como um Estado e com os quais jamais foram travadas relações diplomáticas (se por diplomacia compreendermos as práticas de negociação entre representantes de Estados). Latour, em suas Gifford Lectures, de 2013, considera, a propósito da guerra de Gaia que caracterizaria o Antropoceno, que ela, embora “[...] já tenha começado, precisa ser 'oficialmente' declarada para que as conversações de paz sejam iniciadas" (Danowski e Viveiros de Castro, 2017, p. 120). Para ele, influenciado pelo "pensador tóxico" (idem, p. 119) Carl Schmitt, a política só poderia ter lugar em um espaço sem juízes; qualquer 
conflito no qual um terceiro termo se elevasse com esse feitio é considerado caso de polícia. A guerra, por sua vez, seria o

confronto estritamente imanente, sem possibilidade de intervenção de um árbitro externo ou de uma autoridade superior, no qual é preciso confrontar o inimigo em um cenário onde a aniquilação física (a "negação existencial") do outro é uma possibilidade real (idem).

É preciso explicitar que, para o pensador francês, a guerra que deve ser declarada é aquela travada entre Humanos, os agentes do Antropoceno, e Terranos, difícil conceito que apontaria para o "povo de Gaia"108, em suas configurações guerra em Gaia (entre Humanos e Terranos) ou guerra contra Gaia (Humanos contra Gaia e os Terranos). Em ambas as feições, está em jogo a compatibilidade ou incompatibilidade de mundos ou modos de existência; é a incompatibilidade entre os modos de habitação de Gaia por Humanos e Terranos que pode ser chamada de guerra $^{109}$. Constatando, entretanto, a impossibilidade da reprodução infinita das práticas que culminaram na catástrofe, Danowski e Viveiros de Castro asseveram, sobre essa guerra, que ela já está decidida: "reconheçamos que, de qualquer forma, os Humanos (no sentido de Latour) já perderam a guerra; seu mundo já acabou" (idem, p. 160).

Por outro lado, as guerras travadas contra animais no Antropoceno são frequentemente declaradas; há documentos, estudos, artigos, livros, normativas e mesmo departamentos e agências governamentais que não escondem a sua natureza. Há programas que visam explicitamente o extermínio de animais

${ }^{108}$ Para uma discussão acerca dos entes e povos que constituiriam esse povo, cf. Costa, 2017 e Danowski e Viveiros de Castro, 2017 (p. 111-130): "Por vezes [...] são concebidos como uma rede emergente de cientistas latourianos independentes (em oposição aos cientistas modernistas e seus patrões corporativos), praticantes de uma ciência 'plenamente encarnada', dinâmica, politizada e orientada para nosso mundo sublunar; [...] Outras vezes, os Terranos aparecem como o nome de uma causa comum, que concerne a todos os coletivos do planeta, mas que só pode se consolidar se os futuros ex-Modernos fizerem seu ansiosamente aguardado voto de humildade e abrirem o espaço de interlocução cosmopolítica" (Danowski e Viveiros de Castro, 2017, p. 128); esses autores propõem ainda a sua interpretação acerca dos Terranos: “[...] é difícil conceber o povo de Gaia como uma Maioria, como a universalização de uma boa consciência 'europeia'; os Terranos não podem não ser um povo 'irremediavelmente menor' (por mais numerosos que venham a ser), um povo que jamais confundiria o território com a Terra. Eles se parecem assim [...] com aquele povo que falta de que falam Deleuze e Guattari, o povo menor de Kafka e Melville, a raça inferior de Rimbaud, o Índio que o filósofo devém ('talvez 'para que' o índio que é índio se torne ele mesmo outra coisa e se arranque de sua agonia') - o povo por vir, capaz de opor uma 'resistência ao presente' e de assim criar 'uma nova terra', o mundo por vir (Deleuze e Guattari 1991: 104-05)" (idem, p. 130). Para uma articulação entre o conceito de Terranos e aquele de "povo que falta" deleuziano com foco no animais, cf. Fausto, 2013. Nesse sentido, mesmo que o povo de Gaia não seja identificado aos povos animais, estes últimos povos fariam parte dele.

${ }^{109}$ Agradeço à Déborah Danowski pela formulação, em comunicação pessoal, desta guerra em termos de compatibilidade e incompatibilidade. 
errantes, entidades como a Wild Dog Destruction Board, a "guerra ao mosquito" e seus slogans como "um mosquito não pode ser mais forte que um país inteiro". E entretanto, a enunciação do estado de guerra não parece nesses casos ter dado início a negociações de paz - a não ser que consideremos as iniciativas de conservação (como aquelas promovidas pelo ICMBio, pelas comissões da União Europeia ou pelas agências ambientais norte-americanas) por parte destes mesmos Estados em guerra contra espécies animais, como tentativas nesse sentido. Mas a manutenção de políticas nefastas direcionadas a esses povos depõe contra uma possível boa fé diplomática.

Ainda que possa ser um conceito bom para pensar a situação dos animais no Antropoceno, a guerra talvez não o seja para pensar com os animais. De sua parte, em vez de ofensivas contra o anthropos, eles resistem e buscam saídas como e quando podem. Um dos efeitos da guerra contra as raposas-voadoras, Rose explica, foi o surgimento em humanos de doenças causadas por vírus que podem ter sido carregados por elas há muito tempo. Seguindo o imaginário da guerra, poderíamos interpretar essas zoonoses como contra-ataques dos morcegos. Mas, como argumenta Haraway, "os inimigos de Schmitt não permitem que a história mude em sua medula; os Terranos precisam de uma história de vida mais tentacular e menos binária" (Haraway, 2016b, p. 43) do que as oferecidas pelas "provas de força [trials of strenght]" (idem, p. 42). Manter-se no imaginário da guerra schmittiana fecha as portas para a irrupção de linhas de fuga; arranjos nãobinários e tentaculares só têm lugar em histórias que não suponham apenas duas posições cujo objetivo é a disputa de poder. Dito de outro modo, a compreensão da contaminação humana por vírus que as raposas-voadoras portam como uma ação bélica da parte delas capturaria os envolvidos em uma história de ataques uns contra os outros que talvez só terminasse com a "aniquilação física" de um dos lados - muito provavelmente o das raposas-voadoras, como mostram os acelerados processos de extinção animal. De fato, nesse caso, as estratégias de manejo utilizadas para o combate aos vírus transmitidos por elas envolve sua dispersão e abate. Do mesmo modo, o destino reservado ao gado infectado pela encefalopatia espongiforme bovina, doença que, de acordo com esse imaginário, também poderia ser entendida como um contra-ataque, é a morte seguida de cremação. Considerar, portanto, tais respostas como investidas militares animais significaria tomá-los por soldados suicidas formando patrulhas ineficazes: nem a 
existência das zoonoses transmitidas pelas raposas-voadoras nem a Doença da Vaca Louca resultaram em alguma melhoria na situação desses animais. Pelo contrário, as consequências para eles têm sido mortíferas.

Ainda nos termos desse tipo de guerra, tais efeitos deveriam ser concebidos como novas agressões por parte de seus inimigos. O desequilíbrio entre forças que faz com que as baixas animais sejam sempre muito maiores que as de seus inimigos humanos, aquilo mesmo de que a Sexta Grande Extinção dá testemunho, mostra que essa é uma narrativa sem saída, na qual o surgimento do novo ou a herança de outras formas de relação não encontra lugar. Além disso, permite compreender que, do lado outro que humano, não se está respondendo à guerra com mais guerra: os animais não parecem comungar dessa concepção antropocênica. De sua parte, a fluência de suas existências depende antes de alianças e encontros criadores e inventivos entre eles e com seus aliados humanos - em projetos de conservação ou na transformação e adaptação de seu comportamento. Essas não são ações de guerra mesmo quando envolvem enfrentamento, como no caso do "roubo" de alimento em plantações, na constituição de bandos ferais em florestas urbanas ou mesmo quando membros da ALF invadem laboratórios para libertar animais, pois seu objetivo não é a imposição de um só mundo em detrimento de outros, mas a possibilidade da própria sobrevivência em um mundo que, mais que danificado, é muitas vezes hostil, além da manutenção das articulações necessárias à continuidade de comunidades ecológicas. Nesse sentido, as alianças fluentes e inventivas dos e com os animais não cabem na história daquela guerra, com seus heróis e destinos épicos.

No ensaio "The Carrier Bag Theory of Fiction”, Le Guin propôs uma teoria da ficção baseada na bolsa, talvez o primeiro "dispositivo cultural”, desenvolvido para que fosse possível carregar artigos coletados ou para, por exemplo, transportar crianças. Essa "teoria bolseira" foi concebida por ela como uma saída ao mito do herói, invariavelmente "triunfante (o Homem conquista a Terra, o espaço, alienígenas, a morte, o futuro etc.) e trágico (apocalipse, holocausto, no passado ou agora)" (Le Guin, 1990, p. 170). Triunfo e tragédia são ambas histórias que urdiram o Antropoceno: a vitória sobre a natureza ou o fim do mundo anunciado. Nessas histórias, o herói é o protagonista da guerra e o seu 
mito fundador é aquele da agressão, tal como encenado pelo cineasta Stanley Kubrick em 2001 - Uma odisseia no espaço (2001: A Space Odissey):

Onde está aquela coisa maravilhosa, grande, longa, dura, um osso, eu acho, com que o Homem Macaco primeiro esmagou alguém no filme, e então, grunhindo em êxtase por ter conquistado o primeiro assassinato próprio, lançou para o céu, e rodopiando ali tornou-se uma nave espacial penetrando seu caminho até o cosmos para fertilizá-lo e produzir ao fim do filme um feto adorável, um menino, claro, à deriva pela Via Láctea sem (estranhamente) nenhum útero, nenhum tipo de matriz? Eu não sei. Nem me importo. Não estou contando essa história. Nós já a ouvimos, já ouvimos tudo sobre paus e lanças e espadas, as coisas de esmagar e espetar e de bater, as coisas longas e duras, mas não ouvimos a respeito da coisa de por coisas dentro, do recipiente para a coisa contida. Essa é uma história nova (idem, p. 166167).

A história que Le Guin pretende contar no lugar da do herói, aquela das bolsas que guardam, transportam e são constantemente rearranjadas - da qual fazem parte "mitos de criação e transformação, histórias de trickster, contos populares, piadas, romances...” (idem, p. 168) -, a autora explica, é nova apenas na medida em que foi historicamente abafada pela história de "como o mamute caiu sobre Boob e como Caim caiu sobre Abel e como a bomba caiu sobre Nagasaki e como a geleia ardente caiu sobre os aldeões e como os mísseis cairão sobre o Império do Mal e todos os outros passos da Ascensão do Homem" (idem, p. 167-168); sua origem, na verdade, seria muito antiga, sendo ela a "história da vida" (idem, p. 167), com suas invenções de composição conjunta nas quais pode haver conflitos sem que eles sejam entretanto o sentido principal -, mas tecem relações tensas e contingentes uns com os outros em processos que não buscam "nem a resolução nem a estase" (idem, p. 169). São histórias, poder-se-ia dizer, de povos menores que não engendram projetos de dominação, mas resistem criativamente - nas quais o que está em jogo é a continuidade renovada. É claro que não se guiar pelo conflito, como esclarece Le Guin, não significa não entrar em combates; esses combates, entretanto, são de outra natureza em relação aos do Herói:

Não, que se diga de uma vez, [não sou] um ser humano não agressivo e não combativo. Eu sou uma mulher brava que envelhece, deambulando altivamente com minha bolsa de mão, lutando contra bandidos. Entretanto nem eu nem ninguém me considera heroica por fazer isso. Essa é só uma daquelas malditas coisas que você tem que fazer para continuar coletando aveias selvagens e contando histórias (idem, p. 168).

Essa luta "contra bandidos", como ela deixa claro, é aquilo que lhe permite continuar vivendo e contando "a história da vida", não o motor da vida. Haraway, que percebe na obra da escritora uma "sabedoria situada, mortal e germinal da 
qual precisamos" (Haraway, 2016b, p. 118), comentou, a respeito da recusa do imaginário da guerra:

Não sou contra todas as disputas de força; afinal, adoro basquete feminino. Apenas penso que disputas de força são a história velha. Sobrevalorizadas, elas são como a tarefa nunca terminada de limpar o banheiro - necessárias mas radicalmente insuficientes. Por outro lado, existem excelentes banheiros de compostagem... (idem, p. 179-180).

Necessárias em determinadas situações, mas insuficientes diante do urgente trabalho de composição, decomposição e recomposição de mundos e modos de habitação, as disputas de força e a guerra devem perder sua proeminência em favor das

[...] coisas côncavas e vazias, esses buracos desde o início no Ser, geram histórias mais ricas, mais peculiares, mais plenas, impróprias e fluentes, histórias com lugar para o caçador mas que não eram e não são sobre ele, o humano autopoiético, a máquina fazedora-de-humanos da história. A leve curva da concha que mantém apenas um pouco d'água, apenas algumas sementes para dar e receber, sugere histórias de devir-com, de indução recíproca, de espécies companheiras cujo trabalho na vida e na morte não é terminar a historiação, a mundificação. Com uma concha e com uma rede, devir humano, devir húmus, devir terrano, têm uma outra forma - qual seja, a forma serpentina e sinuosa do devir-com (idem, p. 118-119).

Trata-se sobretudo de uma questão de investimento - de que histórias cultivar, em quais se lançar e quais considerar como aquelas que melhor promovem o surgimento de saídas. As histórias que Le Guin privilegia são aquelas sem fim - tanto no sentido de finalidade como de término. "Ainda há sementes para serem coletadas e espaço na bolsa das estrelas" (Le Guin, 1990, p. 170), conclui a escritora. No tempo acelerado do Antropoceno, entretanto, essas sementes vão rareando (ou sendo patenteadas e monopolizadas) e o espaço diminuindo. Woolf, que Le Guin menciona em seu ensaio, havia concluído o seu Three Guineas com uma resposta à pergunta de um homem sobre como as mulheres poderiam ajudar a prevenir a guerra; para ela, o melhor jeito de fazer isso era, "não repetindo suas palavras e seguindo seus métodos, mas procurando novas palavras e criando novos métodos" (Woolf, 2006, p. 3150). As palavras e os métodos a que a escritora inglesa se referia são aquelas da guerra, envolvidas na história do herói e da "Ascensão do Homem". "Podemos ajudá-los melhor a prevenir a guerra, não ao juntarmo-nos à sua sociedade, mas permanecendo fora de sua sociedade porém em cooperação com seu objetivo" (idem), ela continua. Talvez não seja possível, hoje e com os animais, concordar quanto a esse objetivo descrito como "afirmar os "direitos de todos - todos os homens e mulheres - no 
que diz respeito em suas pessoas aos grandes princípios de Justiça e Igualdade e Liberdade" (idem). Primeiro pelo motivo óbvio de que os animais não fazem parte da meta, mas também porque os "grandes princípios" invocados pela autora, sobretudo em sua versão maiusculizada, revelam, diante das populações menores, uma face monstruosa. Deixemos isso de lado, no entanto, pois o que interessa em sua formulação é a ideia de que é melhor procurar novas palavras, novos métodos do lado de fora da sociedade dos homens. Woolf não fala de todos os lugares ou em nome de todas as mulheres; ela se coloca como parte da classe das "filhas dos homens educados" (idem, p. 916). A sociedade que essas mulheres poderiam encontrar fora daquela "procissão dos filhos dos homens educados", na qual elas trabalhariam "em sua própria classe - como de fato podem trabalhar em alguma outra?" (idem, p. 2533), ela explica a seu interlocutor masculino, é uma outra:

Em primeiro lugar, esta nova sociedade, você ficará aliviado em saber, não teria tesoureiro honorário, pois não precisaria de fundos. Não teria escritório, nem comitê nem secretária; não convocaria reuniões; não organizaria conferências. Se um nome ela tiver de ter, chamar-se-ia Sociedade de Outsiders (idem).

Essa sociedade, "anônima e secreta" (p. 2597), na qual se age situadamente desde o lado de fora da sociedade maior, masculina e da guerra, talvez seja uma figuração mais de acordo com as ações de resistência e criação dos animais e seus aliados. Em vez de uma grande e única Sociedade de Outsiders, quem sabe poderíamos pensar em incontáveis sociedades desse tipo, nas quais as diferenças de perspectiva são multiespecífica e emaranhadamente performadas e transformadas em devires-com. Não se trataria, é claro, de uma sociedade edênica e inocente, mas responsável diante dos entrelaçamentos que compreendem vida, morte, continuidade e descontinuidade, como vimos mostrando durante o percurso desta tese - diferentemente daquela composta pela "procissão dos filhos de homens educados", agitada pela grande história heroica e trágica da Ascensão do Homem. No lugar de princípios grandiosos e demasiadamente humanos, essas sociedades guiar-se-iam pelo desejo de manutenção e criação dos nós ecológicos que multiplicam a vida em suas diferentes configurações. Prevenir a guerra não é mais uma possibilidade, mas ainda é possível recusá-la e resistir a ela, com o objetivo de, habitando responsavelmente os problemas por meio de arranjos multiespecíficos, adiar o fim das histórias.

Rose encerra seu artigo sobre as raposas-voadoras insistindo que “compreender-se como parte de uma comunidade de vida é aceitar 
responsabilidades e também aceitar a vulnerabilidade" (Rose, 2011a, p. 133). Ela conta que encontrou uma mulher cuja voz falava com raiva sobre os brancos terem recentemente visitado comunidades aborígenes para lhes ensinar a não encostar naqueles animais: "não caçá-las, não manuseá-las, não comê-las, não manter nenhum contato físico pois as raposas-voadoras podem carregar doenças" (p. 133-134):

O avô de Gerry [a mulher] havia tomado um tiro e sido morto nos dias antigos, alguns de seus parentes haviam sido envenenadas, muitos membros de sua família viram cachorros ser brutalmente alvejados e o envenenamento de dingos continua sendo uma característica do terrorismo contra animais na região. Todos eles gente e seus parentes animais - sentiram o peso opressivo das decisões de vida e morte tomadas em outra parte e impostas implacavelmente (idem, p. 134).

"O terror, não se deve esquecer, é exercido como um projeto multiespecífico" (idem), lembra a antropóloga. Mais uma vez em nome de uma iniciativa de saúde pública que vem procurar sanar problemas criados por modos catastróficos de habitar o mundo, como quando na modernização da cidade do Rio de Janeiro os animais errantes foram transformados em pestes, um poder que se impõe de cima veio exigir que as antigas relações entre raposas-voadoras e aquelas pessoas fossem cortadas, suprimidas - claro, para o próprio "bem" delas. Para os agentes do governo que vinham constranger os aborígenes a parar de tocar os morcegos, o vínculo entre eles se resumia à caça e à comida. É claro que essas relações são importantes, mas elas não se esgotam aí. As raposas-voadoras, que "vêm interagindo com humanos por milhares de anos antes de terem encontrado ingleses ou grandes chapéus de sol” (idem, p. 122), fazem parte das "histórias de criação, dos ancestrais do Dreaming que caminharam sobre a terra fazendo relevos, espécies, culturas, linguagens, comunidades bióticas e conexões” (idem). Elas compõem, com humanos, grupos matrilineares de raposas-voadores, entre povos da região do rio Victoria, no Território Norte, como os Yarralin e os Lingara. Segundo Rose, a pertença à gente das raposas-voadoras (ou povo das raposas-voadoras), que engloba humanos e morcegos, é corpórea: "a carne do grupo de parentesco é compartilhada através dos corpos das pessoas e animais, e é o seu corporificado e co-específico ser no mundo" (idem).

Declarar guerra às raposas-voadoras é, antes de mais nada, acabar com seu mundo, com tudo o que construíram entre si por incontáveis gerações; mas é também, em um efeito cascata, desfazer os nós que as conectam com seus outros, 
humanos ou não. Árvores perdem seus dispersores de sementes, seus parentes transespecíficos, e essa família, com tudo o que ela mantinha de pé, agora mais pobre e disfuncional, vai se desfazendo. $\mathrm{O}$ mesmo acontece com a gente das raposas-voadoras, a quem se impõe um divórcio, proibida que fica de sequer tocar na carne de seus familiares, uma carne que por tanto tempo eles dividiram e agora se encontra envenenada. É esse conjunto de políticas multiespecíficas e concretas, articuladas e entrelaçadas, que vem, ancestral e renovadamente, fazendo mundos naquela região, que é aniquilada pela destruição dos alicerces dos modos de vida das raposas-voadoras. Gerry, a mulher com quem Rose conversou, não aceita tomar parte nesta guerra e resiste: “'elas estão aqui desde sempre', ela disse a respeito de suas parentas raposas-voadoras, 'assim como nós. Não estamos com medo. Elas são família" (idem, p. 134).

A propósito da guerra que se argumentava lutar também em nome das mulheres, Woolf, em linhas famosas, observou que os homens

Estão lutando para satisfazer um instinto de sexo com o qual não posso compartilhar; obter benefícios de que não compartilhei e provavelmente não compartilharei; mas não para satisfazer meus instintos ou proteger a mim ou o meu país. "Pois", a outsider dirá, "de fato, como mulher, não tenho país. Como mulher, não quero nenhum país. Como mulher, meu país é o mundo todo" (Woolf, 2006, p. 2583).

A guerra do Antropoceno não é a guerra dos animais, mas contra os animais. Isso não significa que com eles e diante deles não serão encontrados os entraves mais terríveis, violentos, cruéis - incompatibilidades entre seus modos de habitação e aquele dos Humanos, o que suscitará combates por rexistência. Mas esses combates não são a finalidade de sua política, muito menos o modo pelo qual ela se exprime: eles são "aquelas malditas coisas que você tem que fazer para continuar coletando aveias selvagens e contando histórias", como dizia Le Guin. Para além da guerra e contra ela, há todas as histórias de "indução recíproca", devir e devir-com, para enunciar algumas. Diferentemente do que dizia Woolf, no caso dos animais, seu país é o mundo todo apenas se os considerarmos como essa grande categoria, povoada por uma multiplicidade distinta de seres; mas cada povo animal possui seu país, não aquele delimitado por fronteiras imaginárias ou muros reais, senão aquele país-mundo que é criado e ativado por eles e seus parentes multiespecíficos. Nestes países, que às vezes se estendem por espaços geográficos enormes e atravessam oceanos e no entanto são sempre multiplamente 
habitados, os animais resistem e criam. Não param de fazê-lo. Mesmo diminuindo em número no país chamado por outros de Austrália (como será que elas chamam o seu país?), as raposas-voadoras ainda cuidam de seus bebês, um a cada ano por fêmea, que passam as noites em campos de maternidade enquanto suas mães voam e dançam enamoradamente com as árvores, comendo seus frutos e ajudando em sua reprodução, retornando pela manhã para, depois de terem alimentado a terra com sementes, darem de mamar a eles. Ainda aprendem, adolescentes, com machos dedicados, a mestria do voo durante passeios noturnos nos quais são apresentados ao mundo criado por seus ancestrais, mundo no qual seus pais os depositaram com a fé de que eles possam, renovadamente, de dentro dos escombros e ataques, da morte, do ódio e da destruição, continuar esse trabalho.

Há algumas páginas, mencionei um conto de James Tiptree Jr, “The Women Men Don't See." Nele, um acidente de avião coloca uma mulher e sua filha, um homem americano e o piloto da aeronave, de origem Maya, em uma pequena ilhota caribenha, de onde precisam sair. Em uma reviravolta fantástica, o grupo encontra um barco repleto de alienígenas, com os quais as mulheres preferem ir embora em vez de voltar à civilização humana: "Nós não queremos retornar. Por favor, levem-nos com vocês!" (idem, p. 141), grita a senhora Parsons, aquela que pedia para ser pensada como um gambá, para os extraterrestres, que aceitam seu pedido. Don, o homem branco com quem ela conversava antes, pondera ao final: "Insana. Como uma mulher poderia escolher viver entre monstros desconhecidos, dizer adeus a seu lar, a seu mundo?”, concluindo: “dois de nossos gambás estão faltando" (idem, p. 142). A escritora Karen Joy Fowler, quase 30 anos depois da publicação do conto de Tiptree Jr, em 2002, publicou uma história inspirada por ele, chamada “What I Didn’t See.” A perspectiva muda radicalmente, e em vez do ponto de vista de um homem que não via mulheres, a narradora é uma mulher, já envelhecida, que, sozinha em seu apartamento, resolve contar o que não viu. E o que ela não viu foi um massacre de gorilas perpetrado por seu esposo e colegas dele em uma expedição de que ela também fazia parte, não tendo, porém, sido chamada para testemunhar o horror - por ser mulher. Ser mulher, entretanto, foi o que a levou a ser convidada para a aventura (algo que ela só descobre tarde demais), cujo objetivo era fazer uma representante do sexo feminino atirar em um gorila para que se conseguisse o efeito, em um fantástico raciocínio, de acabar 
com o apelo à matança desses animais - se até uma mulher pode matar um símio desses, onde estaria a emoção de fazê-lo ${ }^{110}$

A certa altura, cansada dos homens, caminhando nua pelo mato para evitar fazer barulho, ela chega a empunhar uma arma contra um gorila macho, que repousava tranquilamente com algumas fêmeas: "O macho estava sentado em um campo de cenouras selvagens, puxando-as e as comendo sem ardor particular. Eu podia ver o seu perfil e o cinza em seu pelo. Ele contraía os dedos um pouco, como um homem escutando música" (Fowler, 2010, p. 2400). "Como um homem" é, para ela, o pecado do gorila:

No couro de sua face vi surpresa, curiosidade, cautela. Algo mais, também. Algo tão humano que me fez sentir como uma velha sem roupas. Eu podia ter atirado nele só por isso, mas sabia que não era certo - matá-lo só porque ele era mais humano do que eu havia antecipado (idem).

O que a narradora vê no gorila é algo parecido com aquilo que Paul du Chaillu, o primeiro branco a matar um gorila, descreveu: uma humanidade desconfortável. Ela, entretanto, não atira. Caso o fizesse, por outro lado, não seria para abater uma "criatura de sonhos infernais", híbrido monstruoso que deve ser submetido, mas justamente por ter reconhecido no gorila um homem; ela fantasia em "poupar as mulheres, libertar as mulheres" (idem, p. 2417), referindo-se às companheiras do animal, mas recua por não "conseguir ver que elas queriam a liberdade." Mais tarde, a outra fêmea do grupo humano, uma garota jovem, desaparece na floresta e fervilham boatos de que um gorila poderia tê-la levado (por oposição a hipóteses mais prováveis, como ter sido morta pelos carregadores nativos com os quais as relações dos aventureiros não eram nada boas; ter se perdido na floresta depois de um passeio inconsequente, e sido morta por algum bicho ou em um acidente; ou mesmo fugido). Os dias passam sem que Beverly, a moça, retorne. A expedição acaba. Apenas anos mais tarde o marido da narradora lhe revela o que realmente

${ }^{110}$ Uma tal empreitada foi de fato arquitetada nos anos 1920, com a mãe de James Tiptree Jr./Alice Sheldon como uma das participantes. Fowler explicou, em entrevista, que descobriu isso ao ler um texto de Haraway constante em Primate Visions: "eu li um ensaio de Donna Haraway que fazia uma afirmação bastante surpreendente [...] de que, no começo dos anos 1920, um grupo fora levado até a floresta pelo homem que dirigia o Museu de História Natural de Nova York, e que seu propósito era fazer com que uma das mulheres matasse um gorila. Seu argumento era o de que os gorilas eram cada vez mais vistos como uma caça excitante e perigosa, e que eles na verdade eram muito gentis, e se uma mulher matasse um, a emoção se esvairia. Então o plano dele era proteger os gorilas ao fazer com que matá-los parecesse algo que qualquer garota pudesse fazer. Eu fiquei mesmerizada (e estupefata) com isso, e um parágrafo depois, fiquei extremamente surpresa ao ler que uma das mulheres que havia ido a essa expedição, uma das mulheres escolhidas por ele para representar esse papel, era a mãe de James Tiptree” (Fowler, 2004, s/p). 
aconteceu, o que ela não viu por ser mulher: a vingança sangrenta dos homens contra os gorilas que lhe teriam tomado uma fêmea: "Senti como se fosse assassinato", o homem confessa, "Exatamente como assassinato" (idem, p. 2447). A história, escrita muito tempo depois do acontecido, é o relato de uma mulher idosa que durante seu período de vida viu a percepção sobre os gorilas mudar por meio de estudos de campo. "Finalmente estão começando a realmente ver como eles vivem" (idem, p. 2463), ela avalia, declarando que gosta de ler artigos sobre primatologia, e que neles:

Minha atenção é levada até essas jovens mulheres que preferem viver na floresta com os chimpanzés ou com os orangotangos ou com os grandes gorilas das montanhas. Essas mulheres que livremente escolheram isso - as Goodalls e as Galdikases e as Fosseys. E penso comigo mesma que não há nada de novo sob o sol, e talvez todas aquelas mulheres raptadas por gorilas nas histórias antigas tenham todas escolhido livremente ir (idem, p. 2474).

Os dois contos, o de Tiptree e o de Fowler, são ambos histórias de traição da Sociedade do Homem. É essa a sociedade da guerra, não o "estado de natureza." O lobo de Homo homini lupus só existe como um delírio Humano sobre os clãs lupinos. Isso não quer dizer que não haja eventos de agressão entre animais e mesmo práticas que podem ser chamadas, por analogia, de guerra ou guerrilha; uma afirmação desse tipo seria injusta por muitos motivos, o primeiro deles sendo a diferença específica e populacional. Chimpanzés podem atacar e matar membros de outros grupos e anexar territórios, formigas conduzem batidas a colônias de outras espécies. Mas a verdade é que não é nenhum grupo animal outro que humano o causador da catástrofe de dimensões planetárias na qual nos encontramos. Nas histórias citadas, mulheres infiéis desertam da comunidade que parece desejar a guerra de todos contra todos e partem para viver com outros, alienígenas e animais, formando tentáculos ou aldeamentos das Sociedades de Outsiders. São essas comunidades e agenciamentos multiespecíficos e infiéis à história da "Ascensão do Homem" que precisam ser cultivados:

Precisamos de algum modo fazer a transmissão [make the relay], herdar o problema e inventar condições para o florescimento multiespecífico, não apenas em uma época de guerras humanas e genocídios incessantes, mas em uma época de extinções em massa impulsionadas por humanos e genocídios multiespecíficos que varrem gente e criaturas para o vórtice. Precisamos 'ousar' 'fazer' a transmissão; isto é, criar, fabular, para não desesperar. De modo a induzir a transformação, talvez, mas sem a lealdade artificial que se pareceria com um 'em nome de uma causa', não importa o quão nobre ela possa ser (Haraway, 2016b, p. 130). 
Nesta tese, ao final de cada capítulo, foram propostos enunciados que, diante dos cenários discutidos, pudessem dar conta de alguns modos animais e com animais de fazer política, como composições provisórias e situadas, brincadeira inventiva, imaginação simpática, interesse, parentesco estranho e invenção de mundos. Se fosse preciso reduzir essas políticas a seus pontos fundamentais - e o lugar mais adequado para isso é esta conclusão -, os dois conceitos capazes de reunir e apontar para todos os outros poderiam ser criação de oddkin e brincadeira. Experimentando-nos animais entre os animais em temporalidades e relações diversas, multiespecificamente laterais, farejando-nos cuidadosamente e convidando-nos a brincar, talvez sejamos capazes de criar novas histórias e herdar responsavelmente aquelas nas quais florescemos juntos, de modo a que as histórias - não mais uma História única - e suas criaturas tenham chance.

A primeira seção do capítulo que abre este trabalho chama-se Pet Sounds, em referência ao álbum da banda norte-americana Beach Boys, lançado em 1966. No final desse disco, depois que a última canção se encerra, ouvimos o som de um trem e de cães latindo; depois que o trem se vai, os animais continuam a vocalizar. Esses cães, Banana, uma beagle, e Louie, um weimaraner, viviam com Brian Wilson, autor das músicas. Sua presença insólita e o lugar privilegiado que ocupam, sendo as últimas vozes ouvidas após uma coleção de elaboradas harmonias vocais humanas, levou o musicólogo Philip Lambert a comentar:

Os cães (Banana e Louie), enquanto isso, oferecem seu próprio comentário mais terrano [earthbound]. Com sua hipersensibilidade e senso de audição mais agudo, eles comunicam um entendimento do que se passou - e da vida em geral - que transcendem a compreensão humana. Esses são os "pet sounds" que Brian nos deu, a poesia em som que busca fundo em nossa consciência para enviar mensagens que não podem ser comunicadas de outro modo. Não fale, a música diz, apenas pouse a cabeça em seu ombro e escute (Lambert, 2007, p. 252).

Não fiz outra coisa até aqui senão falar - escrevendo. Gostaria, contudo, que esse trabalho de composição de discursos em torno à cosmopolítica dos animais pudesse fazer, como Wilson, Louie e Banana, um movimento do lógos até a phoné, da excepcionalidade humana à animalidade compartilhada, movimento capaz de (re)inserir o lógos no mundo, tornando-se, para além de toda escrita, uma voz entre vozes. Um desejo de difícil realização, dir-se-ia mesmo impossível - 
como o fim da escravidão ou a própria escravidão. Mas, como ensinou o filósofo Paul Beatriz Preciado, “o impossível está por vir. E o inimaginável nos é devido.” Portanto - que esta tese possa latir! 


\section{7 \\ Referências bibliográficas}

ADANG, O. 2016. "The Most Powerful Chimpanzee of the Netherlands." Disponível em <http://chimpansee.homestead.com/book.html〉. Acesso em 07/07/2017.

AGAMBEN, G. 2002. Homo Sacer. O poder soberano e a vida nua I. Tradução de Henrique Burigo. Belo Horizonte: Editora UFMG

. 2004. Estado de exceção. Tradução de Iraci D. Poleti. São Paulo: Boitempo editorial.

2007. Lo abierto: el hombre y el animal. Traducción de Flavia Costa y Edgard Castro. Buenos Aires: Adriana Hidalgo Editora.

2009. "O amigo." In O que é o contemporâneo? e outros ensaios. Tradução de Vinícius Nicastro Honesko. Chapecó: Argos, p. 77-9.

ANDERS, G. 2007. Le Temps de la fin. Paris: L'Herne.

. 2013. "Teses para a era atômica." Tradução de Alexandre Nodari e Déborah Danowski. Sopro: Panfleto Político-Cultural, n. 87, abril/2013.

AHLHAUS, S.; NIESEN, P. 2015. "What is Animal Politics? Outline of a New Research Agenda." Historical Social Research, vol. 40, n. 4, p. 7-31.

ANDRADE, O. de. 1978. "Meu testamento." In Obras Completas de Oswald de Andrade, vol. VI. Do Pau-Brasil à Antropofagia e às Utopias. Rio de Janeiro: Civilização Brasileira.

ANIMAL LIBERATION FRONT. S/d. "Alf Actions Around The World." Disponível em $\quad$ http://www.animalliberationfront.com/ALFront/Actionsindex.htm>. Acesso em 07/08/2017.

A REPÚBLICA. Orgão do Partido Republicano. Paraná, Curitiba. Disponível na Hemeroteca Digital da Biblioteca Nacional.

ARENDT. H. 1992. Lectures on Kant's Political Philosophy. Edited and with an Interpretative Essay by Ronald Beyer. Chicago: The University of Chicago Press.

ARISTÓTELES. 1837. Opera ex recensione Immanuelis Bekkeri. Historia Animalium, Tomus IV. Oxonii.

$\begin{array}{ccr}\text {. 1894. Ethica Nicomachea. Edited by J. Bywater. } & \text { (Oxford: Clarendon } \\ \text { Press), } & \text { Perseus } & \text { Digital }\end{array}$ 
$<$ http://www.perseus.tufts.edu/hopper/text?doc=Perseus\%3atext\%3a1999.01.005 $>$ . Acesso em 07/07/2017.

2002. Politics. Books I and II. Translated with a Commentary by Trevor J. Saunders. Oxford: Clarendon Press.

ASCHENBACH, A.; FOITZIK, S. 2009. "First evidence for slave rebellion: Enslaved ant workers systematically kill the brood of their social parasite Protomognathus americanus." Evolution, v. 63, n.4, p. 1068-1075.

AZEVEDO, A. L. 2016. "Cães abandonados viram predadores na Floresta da Tijuca." O Globo. Rio de Janeiro, 28/06/2016. Disponível em $<$ https://oglobo.globo.com/sociedade/sustentabilidade/caes-abandonados-virampredadores-na-floresta-da-tijuca-19583787>. Acesso em 07/08/2017.

BACON, F. 1834. "The Masculine Birth of Time." In The Works of Francis Bacon. Vol. 15. London: William Pickering, p. 223-224.

BAILEY, C. 2011. À la mesure du Dasein: la genése des existentiaux dans la vie animale chez Heidegger [1919-1927]. Mémoire présenté à la Faculté des études supérieures en vue de l'obtention du grade de Maître ès arts en philosophie. Montréal: Département de philosophie de la Université de Montréal.

BAYLE, P. 1684. Nouvelles de la republique des lettres. Moi de mars 1684. Amsterdam, chez Henry Desbordes, dans le Kalver-Straat, prés de Dam.

1730. Dictionnaire historique et critique. Tome 4. Quatrième édition, Amsterdam, chez P. Brunel, et al; 4 vols. in-folio. Avec la vie de l'auteur par $\mathrm{Mr}$ des Maizeaux.

BARAD, K. 1996. "Meeting the Universe Halfway: Realism and Social Constructivism Without Contradiction." In NELSON, L. C.; NELSON, J. (Eds.) Feminism, Science, and the Philosophy of Science. Dordrecht: Kluwer Academic Publishers, p. 161-194.

2007. Meeting the Universe Halfway. Quantum Physics and the Entanglement of Matter and Meaning. Durham: Duke University Press.

34, p. 76-81.

2012. Intra-actions [Interview to Adam Kleinman]. Mousse Magazine, $\mathrm{n}$.

BARATAY, E. 2017. Biographies Animales. Paris: Éditions du Seuil. Edição Kindle.

BARATAY, E.; HARDOUIN-FUGIER, E. 1998. Zoos. Histoire des jardins zoologiques en Occident (XVI-XX siècle). Paris: La Découverte. Edição Kindle.

BARBIER, A. A. 1806. Dictionnaire des ouvrages anonymes et pseudonymes. Composés, traduits ou publiés en français, avec les nomes des Auteurs, Traducteurs et Éditeurs; Accompagné de Notes historiques critiques. Tome second. Paris: Imprimerie Bibliographique. 
BARNOSKY, A, D. et al. 2011. "Has the Earth sixth mass extinction already arrived?" Nature, v. 471, p. 51-57.

BARROW JR, M.V. 2009. Nature's Ghosts. Confronting Extinction From the Age of Jefferson to the Age of Ecology. Chicago: The University of Chicago Press.

BATESON, G. 2000. Steps to an Ecology of Mind. Chicago: The University of Chicago Press.

BEKOFF, M. 1984. “Social play behavior”. Bioscience, v. 34, n. 4, p. 228-233.

2001. "Social play behaviour. Cooperation, fairness, trust, and the evolution of morality." Journal of Consciousness Studies, v. 8, n. 2, 81-90

. 2016. "Cat Wars' Calls For Killing Free-Ranging Cats". Psychology Today. Site. Disponível em <https://www.psychologytoday.com/blog/animalemotions/201608/cat-wars-calls-killing-free-ranging-cats $>$ Acesso em 07/07/2017.

BEKOFF, M.; PIERCE, J. 2009. Wild Justice: the moral lives of animals. Chicago: The University of Chicago Press.

BERGER. J. 2009. "Why look at animals.” In Why Look At Animals? London: Penguin Books, p. 12-37.

BERGSON, H. 1909. L’Évolution Créatrice. Paris: Félix Alcan.

BISKIND, P. 2000. Seeing is Believing: How Hollywood Taught us to Stop Worrying and Love the Fifties. New York: Henry and Holt Company. Edição eletrônica.

BONES, V. C. 2012. "O uso de animais em aulas práticas do Ensino Médio." Educação e cidadania, n. 14, p. 8-15.

2014. Contribution to the Implementation of Validated Alternative Methods for Rabies Diagnosis. UFPR. Tese de doutorado. 127 páginas.

BONVICINO, C. R.; OLIVEIRA, J. A.; D'ANDREA, P. S. 2008. Guia dos roedores do Brasil, com chaves para gêneros baseadas em caracteres externos. Rio de Janeiro: Centro Pan-Americano de Febre Aftosa - OPAS/OMS.

BOULWARE, J. 1995. "Slap Shots”. SF Weekly, 19/07. Disponível em <http://archives.sfweekly.com/sanfrancisco/slap-shots/Content?oid=2132249>. Acesso em 07/07/2017.

BRASIL. 1998. Lei Federal $\mathbf{n}^{\circ}$ 9.605, de 12 de fevereiro de 1998. Disponível em <http://www.planalto.gov.br/ccivil_03/leis/L9605.htm>. Acesso em 07/07/2017.

BRAVERMAN, I. 2013. Zooland: The Institution of Captivity. Stanford: Stanford University Press. 
BROD, M. 1956. Franz Kafka, una biografia. Traduzione di Ervino Pocar. Milano: Biblioteca Alberto Mondadori.

BUCHANAN, B. 2008. Onto-ethologies. The Animal Environments of Uexküll, Heidegger, Merleau-Ponty, and Deleuze. Albany: State University of New York Press.

CABRERA, M. L. 1982. La esclavitud em las canarias orientales en el siglo XVI (negros, moros y moriscos). Santa Cruz de Tenerife: Ediciones del Excmo. Cabildo Insular de Gran Canaria.

CALMETTE, A. 1924. "Le laboratoire Pasteur de Kindia (Guinée Française).” La Nature, n. 2638 (Octobre 25), p. 257-262.

CAMPOS, A. 2001. Coisas e anjos de Rilke. São Paulo: Editora Perspectiva.

CARD, O. S. 1994. Speaker for the Dead. New York: Tor.

CARONE, M. 2002. "Posfácio. Histórias de um mestre no fim da vida." In KAFKA, F. 2002. Um artista da fome/A construção. São Paulo: Companhia das Letras, p. 111-114.

CARROLL, L. 1998. Alice's Adventures in Wonderland. With Forty-Two Illustrations by John Tenniel. Chicago: VolumeOne Publishing.

CARVALHO, R. N. B. Metamorfoses em tradução. 2010. 158 p. USP. Relatório de pós-doutoramento. Disponível em $<$ http://www.usp.br/verve/coordenadores/raimundocarvalho/rascunhos/metamorfo sesovidio-raimundocarvalho.pdf $>$. Acesso em 07/07/2017.

CASTRO, E. A.; POSSE, Z. C. S. 2015. Os 75 anos do Matadouro Municipal de Guabirotuba. Arquitetura, urbanização e higienismo. Curitiba: Edição das autoras.

CEBALLOS, G. et al. 2015. "Accelerated modern human-induced species losses: Entering the sixth mass extinction." Science Advances, n.1, p. 1-5. Disponível em $\langle$ http://advances.sciencemag.org/content/advances/1/5/e1400253.full.pdf $>$.

Acesso em 18/07/2017.

CEBALLOS, G.; EHRLICH, P.R.; DIRZO, R. 2017. "Biological annihilation via the ongoing sixth mass extinction signaled by vertebrate population losses and declines." PNAS USA; published ahead of print July 10, 2017, p. 1-8. Disponível em $\langle$ http://www.pnas.org/content/early/2017/07/05/1704949114.full.pdf $>$. Acesso em 18/07/2017.

CHAPMAN, C, WRANGHAM, R e CHAPMAN, L. 1995. Ecological constraints on group size: an analysis of spider monkey and chimpanzee subgroups." Behavioral Ecology and Sociobiology, 36 (1), p. 59-70.

CHAKRABARTY, D. 2013. "O clima da história: quatro teses." Sopro: Panfleto político-cultural, 91, julho/2013. Tradução de Denise Bottmann et al. Disponível em <http://www.culturaebarbarie.org/sopro/n91s.pdf $>$. Acesso em 07/07/2017. 
CZECHOWSKI, W; GODZINSKA, E. J. 2015. "Enslaved ants: not as helpless as they were thought to be." Insectes Sociaux, 62, p. 9-25.

CLASTRES, H. 1980. "Primitivismo e ciência do homem no século XVIII." Discurso, n. 13.

CLASTRES, P. 2011. "Arqueologia da violência: a guerra nas sociedades primitivas.” In Arqueologia da violência. São Paulo: Cosac Naify, p. 215-250.

COETZEE, J. M. 2009. A vida dos animais. Tradução de José Rubens Siqueira. São Paulo: Companhia das Letras.

. 2013."The Old Woman and the Cats." In COETZEE, J. M.; de BRUYCKERE, B.; PARRET, H. Cripplewood/Kreupelhout: $5^{\text {th }}$ International Art Exhinition: The Venice Biennale (La Biennale Di Venezia). Brussels: Mercatorfonds, p.7-27.

COTTINGHAM, J. 1978. "A brute to the brutes? Descartes treatment of animals". Philosophy, n. 53, p. 551-559.

COUZIN, I. 2006. "Behavioral ecology: social organization in fission-fusion societies.” Current Biology, v. 16, n. 5, p. 169-171.

COUZIN, I. e LAIDRE, M. 2009. "Fission-fusion populations." Current Biology, v. 19, n. 15, p. 633-635.

CUARÓN, A.D. et al. 2008. "Ateles geoffroyi." The IUCN Red list of Threatened Species. Disponível em <http://www.iucnredlist.org/details/2279/0 $>$. Acesso em 07/07/2017.

DANIEL, Pe. G. 1702. Voyage du monde de Descartes (Nouv. éd. rev. et augm.) nouv. éd. rev. et augm. d'une cinquième partie... par le P. G. Daniel. Disponível em $\quad<$ http://visualiseur.bnf.fr/CadresFenetre?O=NUMM64905\&I=2\&M=tdm>. Acesso em 07/07/2017.

DANOWSKI, D.; VIVEIROS DE CASTRO, E. 2017. Há mundo por vir? Ensaio sobre os medos e os fins. $2^{\text {a }}$. Ed. Desterro (Florianópolis): Cultura e Barbárie/Instituto Socioambiental.

DARNTON, R. 1999. The Great Cat Massacre And Other Episodes in French Cultural History. New York: Basic Books.

DARWIN, C. 1859. On the Origin of Species by Means of Natural Selection or the Preservation of Favoured Races in the Struggle for Life. London: John Murray.

1871. The descent of man, and selection in relation to sex. London: John Murray. Volume 2. 1st edition. Disponível em $<$ http://darwinonline.org.uk/content/frameset?itemID=F937.2\&viewtype=text\&pageseq=1 > . Acesso em 07/07/2017.

DE VOS, J.M. et al. 2015. "Estimating the normal background rate of species 
extinction.” Conservation Biology, v. 29, n. 2, p. 452-462.

DE WAAL, F. 1998. Chimpanzee Politics. Power and Sex Among Apes. New York: The Johns Hopkins University Press. Epub.

. 2001. The Ape and the Sushi-Master. Cultural Relections by a

Primatologist. New York: Basic Books. Kindle Edition.

2006. Primates and Philosophers. How Morality Evolved. New Jersey:

Princeton University Press.

2016. Are We Smart Enough to Know How Smart Animals Are?

London: Norton.

DELEUZE, G. S/D. La voix de Gilles Deleuze en ligne. Aula de 09/12/1980.

Disponível em <http://www2.univ-paris8.fr/deleuze/article.php3?id_article=137>. Acesso em 07/07/2017.

1985. Cinéma 2. L’Image-Temps. Paris: Les Éditions de Minuit.

1987. A filosofia crítica de Kant. Tradução de Germiniano Franco. Lisboa:

Edições 70.

34.

1997. Crítica e Clínica. Tradução de Peter Pál Pelbart. São Paulo: Editora

2002. Francis Bacon. Logique de la Sensation. Paris: Éditions du Seuil.

2003a. "Qu'est-ce que 1'acte de création?" In Deux Régimes de Fous.

Textes et entretiens 1975-1995. Édition preparée par David Lapoujade. Paris. Les Éditions de Minuit, p. 291-302.

2003b. Lógica do sentido. Tradução de Luiz Roberto Salinas Fortes. São

Paulo: Editora Perspectiva.

2003c. Spinoza. Philosophie Pratique. Paris: Les Éditions de Minuit.

. 2004. Conversações. Tradução de Peter Pál Pelbart. São Paulo: Editora 34.

DELEUZE, G.; GUATTARI, F. 1975. Kafka. Pour une littérature mineur. Paris: Les Éditions de Minuit.

. 2004. "Micropolítica e segmentaridade." In Mil Platôs. Capitalismo e

Esquizofrenia. Vol. 3. Coordenação da tradução de Ana Lúcia de Oliveira. São Paulo: Editora 34, p. 83-115.

2005. "Devir-intenso, devir-animal, devir-imperceptível." In Mil Platôs. Capitalismo e Esquizofrenia. Vol. 4. Coordenação da tradução de Ana Lúcia de Oliveira. São Paulo: Editora 34, p. 11-113.

2009. O que é a filosofia? Tradução de Bento Prado Jr. e Alberto Alonso Muñoz. São Paulo: Editora 34. 
DELEUZE, G.; PARNET, C. 1998. Diálogos. Tradução de Eloísa Araújo Ribeiro. São Paulo: Escuta.

DEPEW, D. 1995. "Humans and Other Political Animals in Aristóteles's 'History of Animals"'. Phronesis, vol. 40, n. 2, p. 156-181

DERRIDA, J. 2002. O animal que logo sou (a seguir). Tradução de Fábio Landa. São Paulo: UNIFESP.

2009. The Beast and the Sovereign. Vol. 1. Translated by Geofrrey Bennington. London, Chicago: The University of Chicago Press.

DESCARTES, R. 1905. Oeuvres de Descartes. Principia Philosophae. Publiées par Charles Adam \& Paul Tannery sous les auspices du Ministére de L'Instruction Publique. Paris: Léopold Cerf.

1973. Discurso do Método. Meditações. Objeções e respostas. As paixões da alma. Cartas. Introdução de Gilles-Gaston Granger; prefácio e notas de Gérard Lebrun; tradução de J. Guinsburg e Bento Prado Júnior. Coleção Os Pensadores. São Paulo: Abril Cultural.

2004. Oeuvres et lettres. Textes présentés par André Bridoux. Bibliothèque de la Pléiade. Paris, Gallimard.

De Fontenay, E. 1998. Le silence des bêtes. La philosophie à l'épreuve de l'animalité. Paris: Fayard.

DESPRET, V. 2002. Quand le loup habitera avec l'agneau. Paris: Les Êmpecheurs de Penser em Ronde/La Seuil.

2004a. Hans, le cheval qui savai compter. Paris: Les Êmpecheurs de Penser en Rond.

. 2004b. "The Body We Care For: Figures of Anthropo-zoo-genesis." Body and Society, vol. 10, n. 2-3, p. 111-134.

2008. "The becoming of subjectivity in animal worlds" Subjectivity, n. 23, p. 123-139.

2009. "Rencontrer un animal avec Donna Haraway". Critique, n. 747/748, p.745-757.

. 2010. "Responding and Suffering in Human-Animal Worlds." Disponível em <http://www.vincianedespret.be/2010/03/responding-and-suffering-bodies-inhuman-animal-worlds/>. Acesso em 07/07/2017.

. 2014. Que diraient les animaux, si... on leur posait les bonnes questions? Paris: La Découverte/Poche.

. 2017. "Afterword: It Is an Entire World That Has Disappeared." In ROSE, D.B.; van DOOREN, T.; CHRULEW, M. (Eds.). Extinction Studies. Stories of 
Time, Death, and Generations. New York: Columbia University Press. Edição Kindle.

DESPRET, V.; PORCHER, J. 2007. Être Bête. Arles: Actes Sud.

DICK, P. K. 2009. Ubik. Tradução de Ludmilla Hashimoto. São Paulo: Aleph.

DIDEROT, D.; D’ALEMBERT (Eds.). 1765. "Ménagerie”. In Encyclopédie ou Dictionnaire raisonné des sciences, des arts et des métiers. Tome dixieme. Neufchastel: Samuel Faulche.

DILLY, A. 1676. De l'âme des bêtes ou après avoir démontré la spiritualité de l'ame de l'homme, l'on explique par la seule machine, les actions les plus surprenantes des animaux. Disponível em $<$ https://books.google.com.br/books?id=yIAPAAAAQAAJ\&printsec=frontcover $\& \mathrm{hl}=\mathrm{pt}-\mathrm{BR} \# \mathrm{v}=$ onepage $\& \mathrm{q} \& \mathrm{f}=$ false $>$. Acesso em 07/07/2017.

DONALD, P. F. et al. 2010. Facing Extinction. The world's rarest birds and the race to save them. London: $\mathrm{T}$; $\mathrm{AD}$ Poiser.

ERWIN, D. H; DROSER, M. L. 1993. “Elvis Taxa.” Palaios, v. 8, p. 623-624.

FARAGE, N. 2012. "De ratos e outros homens: resistência biopolítica no Brasil moderno." $27 \quad$ p. $\quad$ Disponível em <https://www.academia.edu/5996887/De_ratos_e_outros_homens_resist\%C3\%A Ancia_biopol\%C3\%ADtica_no_Brasil_moderno>. Acesso em 07/07/2017.

. 2013. "No Collar, No Master: Workers and Animals in the Modernization

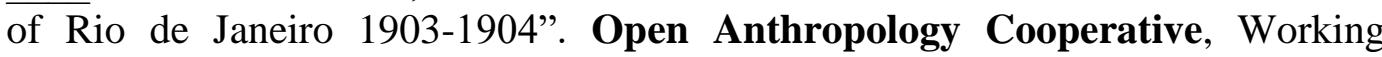
Papers Series, n. 18, p. 1-19. Disponível em <http://openanthcoop.net/press/http://openanthcoop.net/press/wpcontent/uploads/2013/11/Farage-OACP-Working-Paper-182.pdf $>$. Acesso em 07/07/2017.

FARRINGTON, B. 1964. The Philosophy of Francis Bacon: an Essay on its Developments from 1603 to 1609 , with new Translations of Fundamental Texts. Liverpool: Liverpool University Press.

FAUSTO, J. 2012. Poesia versus Filosofia: Agamben e a "palavra despedaçada". 103 páginas. Dissertação de mestrado.

2013. "Terranos e poetas: o "povo de Gaia" como "povo que falta." Revista Landa, vol. 2, n. 1, p. 165-181.

. 2016. "Terra e terror em Phase IV, de Saul Bass." Viso - Cadernos de estética aplicada, vol. x, n. 18, p. 124-141.

FEDERICI, S. 2004. Caliban and the Witch. Women, the Body and Primitive Accumulation. New York: Autonomedia.

FERNANDES, J. C. "Os pecados da carne no Matadouro do Guabirotuba." A Gazeta do Povo. Curitiba, 13/11/2015. Disponível em 
$<$ http://www.gazetadopovo.com.br/vida-e-cidadania/historia/os-pecados-da-carneno-matadouro-do-guabirotuba-eg5gsd42ikkjp547owmxlcz72>. Acesso em 07/07/2017.

FERREIRA, R. 2010. "A primeira partilha da África. Decadência e ressurgência do comércio português na Costa do Ouro (ca. 1637-1700)." Varia Historia, Belo Horizonte, vol. 26, n. 44, p. 479-498.

FREDERICO, J. “O Massacre da Pacheco Fernandes.” Entrevista ao jornal Zona Sul. Disponível em <http://zonasulnatal.blogspot.com.br/2004_04_01_archive.html $>$. Acesso em 07/07/2017.

FOUCAUlT, M. 1975. Surveiller et Punir. Naissance de la Prison. Paris: Gallimard. Gallimard. 2001. "Des autres espaces". In Dits et Écrits II, 1976-1988. Paris: Quarto 2005. Em defesa da sociedade. Curso no Collége de France (1975-1976). Tradução de Maria Ermantina Galvão. São Paulo: Martins Fontes.

FOSSEY, D. 2000. Gorillas in the Mist. Boston: Mariner Books.

FOWLER. K. J. 2004. Interview with Karen Joy Fowler. Strange Horizons, 22/03/2004. Disponível em <http://strangehorizons.com/nonfiction/articles/interview-karen-joy-fowler/> . Acesso em 07/08/2017.

. 2010. "What I Didn't See." In What I Didn't See and Other Stories. Easthampton: Massachusetts. Edição Kindle.

FRANCIONE, G. L. 2008. Animals as Persons: Essays on the Abolition of Animal Exploitation. New York: Columbia University Press.

FUDGE, E. 1999. "Calling Creatures by their True Names: Bacon, the New Science and the Beast in Man". In FUDGE, E; GILBERT, R.; WISEMAN, S. (Eds). At the Borders of the Human Beasts, Bodies and Natural Philosophy in the Early Modern Period. London: Macmillian Press/New York: St Martin's Press, p. 91-109.

FRANKEL, A. (Ed.) 2009. Zoo views: San Francisco Zoological Society 2007 annual report; special 80th anniversary issue. San Francisco: San Francisco Zoological Society.

GALBREATH, R.; BROWN, D. 2004. "The tale of the lighthouse-keeper's cat: Discovery and extinction of the Stephens Island wren (Traversia lyalli)". Notornis, 2004, vol. 51, p. 193-200.

GILBERT, S.; SAPP, J; TAUBER A. 2012. "A Symbiotic View of Life: We Have Never Been Individuals." The Quarterly Review of Biology, vol. 87, n. 4, p. 325-341. 
GIRLICH, K. 2009. San Francisco Zoo. Charleston, Chicago, Portsmouth, San Francisco: Arcadia Publishing.

GUATTARI, F. 1995. Chaosmosis. An etico-aesthetic paradigm. Translated by Paul Bains and Julian Pefanis. Bloomington, Indianapolis: Indiana University Press.

2001. As três ecologias. Tradução de Maria Cristina F. Bittencourt. Campinas: Papirus.

2009. Soft Subversions. Texts and Interviews 1977-1985. Los Angeles: Semiotext(e).

GUERRINI, A. 1989. "The ethics of animal experimentation in seventeenthcentury England.” Journal of the History of Ideas, v. 50, n. 3, p. 391-407.

HALLEY, J. et al. 2016. "Dynamics of extinction debt across five taxonomic groups." Nature Communications, 7, 12283, 8p. Disponível em https://www.ncbi.nlm.nih.gov/pmc/articles/PMC4962471/pdf/ncomms12283.pdf. Acesso em 20/07/2017.

HALLEY, J. M.; IWASA, Y. 2010. "Neutral theory as a predictor of avifaunal extinctions after habitat loss." PNAS USA, v. 108, n. 6, p. 2316-2321.

HANSKI, I; OVASKAINEN, O. 2002. "Extinction Debt at Extinction Threshold.” Conservation Biology, v. 16, n. 3, p. 666-673.

HARAWAY, D. J. 1989. Primate Visions: Gender, Race and Nature in the World of Modern Science. New York, London: Routledge.

1991. Simians, Cyborgs and Women. The Reinvention of Nature. New York: Routledge.

1992. "The Promises of Monsters: A Regenerative Politics for Inappropriate/d Others.” In GROSSBERG, L.; NELSON, C.; TREICHLER, P. (Eds.). Cultural Studies. New York: Routledge, p. 295-337

2000. "Manifesto ciborgue: ciência, tecnologia e feminismo-socialista no final do século XX". In HARAWAY, D.; KUNZURU, T. Antropologia do ciborgue. As vertigens do pós-humano. Belo Horizonte: Autêntica.

2008. When Species Meet. Minneapolis and London: University of Minnesota Press.

. 2011. "SF: Science Fiction, Speculative Fabulation, String Figures, So Far." Pilgrim Award Acceptance Comments. Donna Haraway, July, 7, 2011. Disponível em <https://people.ucsc.edu/ haraway/Files/PilgrimAcceptanceHaraway.pdf $>$. Acesso em 07/07/2017.

2016a. Manifestly Haraway. Minneapolis and London: University of Minnesota Press. 
2016b. Staying with the Trouble: Making Kin in the Chthulhucene. Durham and London: Duke University Press.

. 2016c. "Tentacular Thinking: Anthropocene, Capitalocene, Chthulucene".

e-flux, n. $75, \quad \mathrm{~s} / \mathrm{p}$. Disponível em <http://www.eflux.com/journal/75/67125/tentacular-thinking-anthropocene-capitalocenechthulucene/>. Acesso em 07/07/2017.

HARAWAY, D. et al. 2016. "Anthropologists Are Talking - About the Anthropocene". Ethnos, vol. 81, n. 3, p. 535-564.

HARPER, G. A.; BUNBURY, N. 2015. "Invasive rats on tropical islands: Their population biology and impacts on native species." Global Ecology and Conservation, v. 3 , p. 607-627.

HART, L.; WOOD, M.; HART, B. 2008. Why dissection? Animal use in education. Westport: Greenwood Press.

HEIDEGGER, M. 1990. "Lettre sur l'humanime". Questions III et IV. Trad. de l'allemand par Jean Beauffret, Roger Munier et al. Paris: Gallimard, p. 67-130.

1997. The Fundamental Concepts of Metaphysics. World. Finitude. Solitude. Translated by William McNeill and Nicholas Walker. Bloomington and Indianapolis: Indiana University Press.

2002. "Para quê poetas?" Caminhos de floresta. Coordenação científica da edição e tradução: Irene Borges-Duarte. Lisboa: Calouste Gulbenkian. Piaget.

2004. Hinos de Hölderlin. Tradução de Lumir Nahodil. Lisboa: Instituto

HERBERS, J. M. 2007. "Watch Your Language! Racially Loaded Metaphors in Scientific Research". Bioscience, vol. 57, n. 2, p. 104-105.

HUGHES, T. 1982. Poetry in the Making. An Anthology of Poems and Programmes from "Listening and Writing". London: Faber and Faber.

1995. "The Art of Poetry, 71". The Paris Review, n. 134. Interviewed by Drue Heinz. Disponível em <http://www.theparisreview.org/interviews/1669/theart-of-poetry-no-71-ted-hughes $>$. Acesso em 07/07/2017.

. 2010. "O jaguar". Tradução de Sérgio Alcides. Suplemento literário de Minas Gerais. Outubro/novembro, p. 40.

HUNTER, W. 1803. A Systematic and Historical Exposition of Roman Law in the Order of a Code. London: Sweet; Maxwell, Limited.

HUSTAK, C; MEYERS. N. 2012. "Involutionary Momentum. Affective Ecologies and the Science of Plant/Insect Encounters." differences. A Journal of Feminist Cultural Studies, vol. 23, n. 5, p. 74-118. 
IGCP - International Gorilla Conservation Programme. 2015. Disponível em $<$ http://igcp.org>. Acesso em 07/07/2017.

ICMBio - Instituto Chico Mendes de Conservação da Biodiversidade. Mamíferos - Juscelinomys candango. Moojen, 1965 - Rato Candango. Disponível em $<$ http://www.icmbio.gov.br/portal/faunabrasileira/lista-de-especies/6104-especie6104>. Acesso em 07/07/2017.

JABLONSKI, D. 2002. "Survival without recovery after mass extinctions." PNAS USA, v. 99, n. 12, p. 8139-8144.

KAFKA, F. 1994. "Um relatório para uma Academia". In Um médico rural. Tradução de Modesto Carone. São Paulo: Brasiliense, p. 57-67.

2002. Um artista da fome/A construção. Tradução de Modesto Carone.

São Paulo: Companhia das Letras.

KANT, I. 1984. Fundamentação da metafísica dos costumes. Tradução de Paulo Quintela. In Kant (II). Textos selecionados. Coleção Os Pensadores. São Paulo: Abril Cultural, p. 103-162.

2005. "Resposta à pergunta: Que é 'Esclarecimento'? (Aufklärung)". Tradução de Floriano de Sousa Fernandes. In Textos Seletos. Petrópolis: Vozes, p. 63- 71 .

2006. Antropologia de um ponto de vista pragmático. Tradução de Clélia Aparecida Martins. São Paulo: Iluminuras.

. 2013. Metafísica dos costumes. Tradução de Clélia Aparecida Martins. Petrópolis/Bragança Paulista: Vozes/EDUSF. Edição eletrônica.

KELLER, E. F. 1995. "Baconian Science: the Arts of Mastery and Obedience.” In Reflections on Gender and Science. 10th Anniversary Edition. New Haven and London: Yale University Press.

KLEIN, L e KLEIN. D. (1971) "Aspects of social behavior in a colony of spider monkeys* at San Francisco Zoo.” International Zoo Yearbook, p. 175-181.

KNAPTON, 2016. “"Rat explosion' threatens sooty terns on Ascension Island after cat cull". The Telegraph, 03/12/2016. Disponível em <http://www.telegraph.co.uk/science/2016/12/03/rat-explosion-threatens-sootyterns-ascension-island-cat-cull/>. Acesso em 07/07/2017.

KOLBERT, E. 2014. The Sixth Extinction. An Unnatural History. New York: Henry Hold and Co.

KYMLICKA, W.; DONALDSON, S. 2013. Zoopolis. Oxford: Oxford University Press.

KUUSSAARII, M. et al. 2009. "Extinction debt: a challenge for biodiversity conservation.” Trends Ecol. Evol., n.24, p. 564-571. 
LAMBERT, P. 2007. Inside the Music of Brian Wilson. New York: Continuum.

LATOUR, B. 1994. Jamais Fomos Modernos: ensaio de antropologia simétrica. Tradução de Irineu da Costa. Rio de Janeiro: Editora 34.

2004. Politics of Nature: How to Bring the Sciences into Democracy. Translated by Catherine Porter. Cambridge, MA: Harvard University Press.

. 2006. "Des sujets récalcitrants." Chroniques d'un amateur des sciences.

Paris: Presses de Mines, p. 187-189.

2011. "Waiting for Gaia: Composing the common world through arts and politics." A lecture at the French Institute, London, November 2011 for the launching of SPEAP. Disponível em <http://www.brunolatour.fr/sites/default/files/124-GAIA-LONDON-SPEAP_0.pdf >. Acesso em 07/07/2017.

LE DOEUFF, M. 2003. The Sex of Knowing. Translated from the French by Kathryn Hamer and Lorraine Code. New York: Routledge.

LE GUIN, U. K. 1990. "The Carrier Bag Theory of Fiction.” In Dancing at The Edge of The World. Thoughts on Words, Women, Places. New York: Harper \& Row, p. 165-170.

2009. "Cheek by Jowl: Animals in Children's Literature" In Cheek by Jowl. Seattle: Acquedut Press, p. 43-108.

2014. The Real and The Unreal. The Selected Short Stories of Ursula

K. Le Guin. New York: Saga Press. Edição Kindle.

. 2016. Late in the Day. Poems 2010-2014. Oakland: PM Press.

LEIGHNINGER JR, R. 1996. "Cultural Infrastructure: The Legacy of New Deal Public Space.” Journal of Architecture Education, 49 (4), p.. 226-236.

LEITE, Y; PATTERSON, B. 2008. “Juscelinomys candango.” The IUCN Red List of Threatened Species. Disponível em < http://www.iucnredlist.org/details/10946/0>. Acesso em 07/07/2017.

LEOPOLD, A. 2008. Pensar como uma montanha. A Sand County Almanac. Águas Santas: Edições Sempre-em-pé.

LEVI, P. 1988. É isto um homem? Rio de Janeiro: Rocco.

LÉVI-STRAUSS, C. 2009. "A lição de sabedoria das vacas loucas.” Estudos Avançados, vol. 23, n. 67, p. 211-216.

. 2013. “Jean-Jacques Rousseau, fundador das ciências do homem”. In Antropologia estrutural dois. Tradução de Beatriz Perrone-Moisés. São Paulo: Cosac Naify, p. 45-55 
LEWIS, C. T; SHORT, C. 1879. A Latin Dictionary Founded on Andrews' Edition of Freund's Latin Dictionary. Oxford: Clarendon Press.

LORENZ, K. 1995. Os fundamentos da etologia. Tradução de Pedro Mello Cruz e Carlos C. Alberts. São Paulo: Editora da Unesp.

LOURENÇO, D. B. 2016. "As propostas de alteração do estatuto jurídico dos animais em tramitação no Congresso Nacional Brasileiro." Revista jurídica lusobrasileira, ano 2, n. 1, p. 811-839.

LOVELOCK, J.; MARGULIS, L. 1974. "Atmospheric homeostasis by and for the biosphere: the Gaia hypothesis". Tellus, 26, p. 1-9.

MAGALHÃES, F. S. 2005. "Galhou leva... Do vale o impresso ao vale o escrito. Uma história social do jogo do bicho no Rio de Janeiro (1890-1960)." 227 p. Tese de doutorado.

MANN, T. 1952. A Montanha Mágica. Tradução de Herbert Caro. Rio de Janeiro: Editora Globo.

MARGULIS, L. 1996. "Gaia is a tough bitch". In BROCKMAN, J. Third Culture: Beyond the Scientific Revolution. New York: Touchstone, p. 129-146.

MARGULIS, L.; SAGAN, D. 2002. O que é vida? Tradução de Vera Ribeiro. Rio de Janeiro: Jorge Zahar Editor.

MARRA, P.; SANTELLA. C. 2016. Cat Wars: The Devastating Consequences of a Cuddly Killer. Princeton and Oxford: Princeton University Press. Edição Kindle.

MASSUMI, B. 2014. What Animals Teach us about Politics? Durham and London: Duke University Press.

MATHEWS, N. H. de M. s/a. "Bacon: Slave-driver or Servant of Nature? Is Bacon to Blame for the Evils of our Polluted Age?" Disponível em $<$ http://www.sirbacon.org/mathewsessay.htm>. Acesso em 07/07/2017.

MARTIN-HAAG, E. 2008. "Le devenir-animal et la question du politique chez Gilles Deleuze". In GUICHET, J-L. Usages politiques de l'animalité. Paris: L'Harmattan.

MERCHANT, C. 2006. "The Scientific Revolution and The Death of Nature." Isis, vol. 97, n. 3, p. 513-533.

MECH, L. D. 1999. "Alpha Status, Dominance and Division of Labour in Wolf Packs.” Canadian Journal of Zoology, v. 77, p. 1196-1203.

MINTEER, B. 2014. “Is it right to reverse extinction?” Nature, v. 509, p. 261.

MONTAIGNE, M. de. 1965. Essais. Livre Premier. Édition presentée, établie et annotée par Pierre Michel. Préface d'André Gide. Paris: Gallimard. 
MOORE, J. W. (Ed.) 2016. Anthropocene or Capitalocene? Nature, History, and the Crisis of Capitalism. Oakland: PM Press.

NASCIMENTO, D.R. 2005. As pestes do século XX: tuberculose e AIDS no Brasil, uma história comparada. Rio de Janeiro: Editora Fiocruz.

NIEMEYER, O. 1998. As curvas do tempo: memórias. Rio de Janeiro: Revan.

O’MALLEY, C.H. 1964. Andreas Vessalius of Brussels, 1514-1564. Berkeley and Los Angeles: University of California Press

ORWELL, G. 2009. 1984. Tradução de Alexandre Hubner e Heloisa Jahn. São Paulo: Companhia das Letras.

PAMMINGER, T. et al. 2012. "Geographic distribution of the anti-parasite trait 'slave rebellion." Evolutionary Ecology, v. 27, p. 39-49.

PAUSANIAS. 2002. Description de la Grèce. Tome VIII. Livre VIII. L'Arcadie. Texte établi par Michel Casevitz. Traduit et comenté par Madeleine Jost. Avec la collaboration de Jean Marcadé. Paris: Les Belles Lettres.

PEPPERBERG, I. M. 2002. The Alex Studies: Cognitive and Communicative Abilities of Grey Parrots. Cambridge and London: Harvard University Press.

PIGNARRE, P.; STENGERS, I. 2005. La sorcellerie capitaliste. Pratiques de désenvoutêment. Paris: La Découverte.

PLATÃO. 1894. Plato's Republic. The Greek Text. Edited with Notes and Essays by B. Jowett, Lewis Campbell. Oxford: Clarendon Press.

1967. La République (VIII-X). Oeuvres completes. Tome VII - 2e

partie. Téxte établi et traduit par Émile Chambry. Paris: Sociéte d'Édition "Les Belles Lettres."

. 1976. Laws. Volume II. Translated by R. G. Bury, Litt. D. London: William Heinemann (The Loeb Classical Library).

2001. Timeu. Crítias. O segundo Alcibíades. Hípias Menor. Tradução direta do grego de Carlos Alberto Nunes. Belém: Editora Universitária UFPA.

PLUMWOOD, V. 1993. Feminism and the Mastery of Nature. London: Routledge.

2003. Environmental Culture. The Ecological Crisis of Reason. New York: Routledge.

2009. "Nature in the Active Voice." Australian Humanities Review, n. 46, Disponível em <http://www.australianhumanitiesreview.org/archive/Issue-May2009/plumwood.html>. Acesso em 07/07/2017.

PORFIRIO. 1984. Sobre la abstinencia. Traducción, introducción y notas de Miguel Periago Lorente. Madrid: Editorial Gredos. 
POVINELLI, E. 2016. Geontologies. A Requiem for Late Liberalism. Durham and London: Duke University Press. Edição Kindle.

PRECIADO, P. B. 2014. "Le féminisme n'est pas um humanisme." Libération, 26/09, s/p. Disponível em <http://www.liberation.fr/chroniques/2014/09/26/lefeminisme-n-est-pas-un-humanisme_1109309>. Acesso em 07/07/2017.

REED, B. C. 2014. The History and Science of the Manhattan Project. Heildelberg, New York, Dordrecht, London: Springer.

REGAN, T. 1983. The Case for Animal Rights. Berkeley: University of California Press.

REIS, N. R. et al (eds). 2006. Mamíferos do Brasil. Londrina: Edição dos autores. Disponível

em

$<$ http://www.uel.br/pos/biologicas/pages/arquivos/pdf/Livro-completo-

Mamiferos-do-Brasil.pdf>. Acesso em 07/07/2017.

RIBARD, D. 2003. Racontre, vivre, penser: histoire(s) de philosophes, 16501766. Paris: Vrin-Ehess.

RILKE, R. M. 1983. Poemas. As elegias de Duíno e sonetos a Orfeu. Prefácio, selecção e tradução de Paulo Quintela. Porto: O oiro do dia.

ROCHA, E. M. 2004. “Animais, homens e sensações.” Kriterion, n. 110, p. 350364.

RODMAN, J. 1980. "Paradigm Change in Political Science. An Ecological Perspective.” American Behavioral Scientist, v. 24, n. 1, p. 49-78.

ROMANO, C. 2009. "Le monde animal: Heidegger et von Uexküll." JOLLIVET, S; ROMANO, C. (eds). Heidegger en Dialogue 1912-1930. Rencontres, affinités, confrontations. Paris: Librarie Philosophique J. Vrin.

ROMERO, R. 2015. A Errática tikmũ'ũn_maxakali: imagens da Guerra contra o Estado. Dissertação de Mestrado. UFRJ. $1 \overline{2} 4 \mathrm{p}$.

ROSE, D. B. 2006. "What if the angel of history were a dog?" Cultural Studies Review, vol. 12, n. 1, p. 67-78.

. 2011a. "Flying Fox: Kin, Keystone, Kontaminant." Australian Humanities Review, n. 50, p. 119-136.

2011b. Wild Dog Dreaming. Love and Extinction. Charlottesville: The University of Virginia Press. Edição Eletrônica.

. 2013. "In the shadow of all this death." In JOHNSTON, J; PROBYNRAPSEY, F. Animal Death. Sydney: Sydney University Press, p. 1-20.

ROSE, D. B.; van DOOREN, T.; CHRULEW, M. 2017. "Introduction. Telling Extinction Stories". In Extinction Studies. Stories of Time, Death, and Generations. New York: Columbia University Press. Edição Kindle. 
ROTHFELS, N. 1996. "Aztecs, Aborigines and Ape-People: Science and Freaks in Germany, 1850-1900." In thomson, R. G. (Ed.). Freakery: Cultural Spectacles of the Extraordinary Body. New York: New York University Press.

2002. Savages and Beasts: The Birth of the Modern Zoo. Baltimore: The Johns Hopkins University Press.

ROUTLEY, R. , PLUMWOOD, V. 1985. "Negation and contradiction"'. Revista Colombiana de Matematicas, n, 19, p. 201-31

ROUX, Sophie. 2013. "Pour une conception polémique du cartésianisme. IgnaceGaston Pardies et Antoine Dilly dans la querelle de l'âme des bêtes." Qu'est-ce qu'être cartesien? Édité par Delphine Kolesnik-Antoine. Lyon: ENS Éditions, p. 315-337.

RUIZ, G.; SANCHEZ, N. 2014. "Wolfgang Köhler's The Mentality of Apes and the Animal Psychology of his Time." Spanish Journal of Psychology, 17, e69, p. $1-25$.

RUST, I. W. 1957. "A Concept of Agribusiness, John H. Davis and Ray A. Goldberg. Boston: Division of Research, Graduate School of Business Administration, Harvard University, 1957. Pp. xiv, 136. \$6.00" (Review). Journal of Farm Economics, vol. 39, n. 4, p. 1042-1045.

SEATON, J; CROOK, T; TAYLOR, D. J.; 2017. "Welcome to dystopia - George Orwell experts on Donald Trump." The Guardian, 25/01/2017. Disponível em <https://www.theguardian.com/commentisfree/2017/jan/25/george-orwell-donaldtrump-kellyanne-conway-1984>. Acesso em 22/07/2017.

SEDDON, P. J.; MOEHRENSCHLAGER, A.; EWEN, J. 2014. "Reintroducing ressurrected species: selecting DeExtinction candidates." Trends in Ecololy \& Evolution, v. 29, n. 3, p. 140-147.

SEKAR, S. 2015. "A few species of ants are pirates that enslave other ants." BBC. 28 de outubro de 2015. Disponível em $<$ http://www.bbc.com/earth/story/20151028-a-few-species-of-ant-are-pirates-thatenslave-other-ants>. Acesso em 07/07/2017.

SCHAPIN, S.; SCHAFFER, S. 1985. Leviathan and the Air-Pump. Hobbes, Boyle, and the Experimental Life. Including a translation of Thomas Hobbes, Dialogus physicus de natura aeris by Simon Schaffer. Princeton: Princeton University Press.

SCHMITT, C. 2006. The Nomos of the Earth in the International Law of the Jus Publicum Europaeum. Translated and annotated by G. L. Ulmen. New York: Telos Press Publishing.

SCHLOSBERG, D.; WISSENBURG, M. 2014. "Introducing Animal Politics and Political Animals." In __. (Eds.) Political Animals and Animal Politics. London: Palgrave-MacMillan, p. 1-14. 
SCHUBERT, G.; MASTERS, R. D. (Eds). 1991. Primate Politics. Carbondale and Edwardsville: Southern Illinois University Press.

SHANNON, L. 2013. The accommodated animal: cosmopolity in shakespearean locales. Chicago: The University of Chicago Press.

SIMONDON, G. 2004. Deux leçons sur l'animal et l'homme. Paris: Ellipses.

SINGER, P. 2002. Ética Prática. Tradução de J. L. Camargo. São Paulo: Martins Fontes.

SMITH, J. E. H. 2011. Divine Machines. Leibniz and the Sciences of Life. Princeton/Oxford: Princeton University Press.

SOBLE, A. 1995. "In Defense of Bacon." Philosophy of the Social Sciences, v. 25 , n. 2, p. 192-215.

SODIKOFF, G. 2012. "Accumulating Absence: Cultural Productions of the Sith Extinction." In SODIKOFF, G. (Ed). The Anthropology of Extinction. Essays on Culture and Species Death. Bloomington and Indianapolis: Indiana University Press, p. 1-16.

. 2013. "The Time of Living-Dead Species. Extinction Debt and Futurity in Madagascar." In PAIK, P. Y.; WIESNER-HANKS, M. (Eds.) Debt: Ethics, the Environment, and the Economy. Bloomington and Indianapolis: Indiana University Press, p. 140-163.

SOHDI, N. S.; BROOK, B.W.; BRADSHAW, C. J. A. 2008 "Causes and Consequences of Species Extinction." In LEVIN, S. A. (Ed). The Princeton Guide to Ecology. Princeton: Princeton University Press, p. 514-520.

SOKOLOWSKY, A. 1908. Beobachtungen über die Psyche der Menschenaffen. Frankfurt am Maim: Neuer Frankfurter Verlag.

SONTAG, S. 1965. "The Imagination of Disaster.” Commentary, October/1965, p. $42-48$.

SOUSA, N. H. B. 2011. "O massacre da Pacheco Fernandes Dantas em 1959: memória dos trabalhadores." Revista Intercâmbio dos Congressos Internacionais de Humanidades (UnB), v. 1, p. 62-87.

SMUTS, B. 2009. "Barbara Smuts." In COETZEE, J. M. A vida dos animais. Tradução de José Rubens Siqueira. São Paulo: Companhia das Letras, p. 128-145.

SNYDER, G. 2005. "Escrita não-natural”. In Re-habitar. Ensaios e Poemas. Tradução e apresentação de Luci Collin. Rio de Janeiro: Azougue.

SORABJI. R. 1993. Animal Minds and Human Morals: The Origins of the Western Debate. Ithaca: Cornell University Press. 
SOUZA, I. M. de A. 2013. "Vidas experimentais: humanos e roedores no laboratório." Etnográfica. Revista do Centro em Rede de Investigação em Antropologia, v. 17, n. 2, p. 241-268.

STENGERS, I. 2002. Penser avec Whitehead: une livre et sauvage création de concepts. Paris: Éditions du Seuil.

2007. "1. La proposition cosmopolitique". In LOLIVE, J.; SOUBEYRAN, O. L’émergence des cosmopolitiques. Paris: La Découverte, p. 45-68.

STRUM, S. 1987. Almost Human. A Journey into the World of Baboons. New York, London: W. W. Norton.

1998. Baboon Tales. Study Guide. Disponível em <http://www.bullfrogfilms.com/guides/baboonguide.pdf > . Acesso em 07/07/2017. 2012. "Darwin's Monkey: Why Baboons Can't Become Human." Yearbook of Physical Anthropology, n. 55, p. 03-23.

TEIXEIRA, H. de A. 1996. No tempo da GEB (1956-1960). Brasília: Thesaurus.

TEN CATE et al. 2009a. "Niko Tinbergen and the red patch on the herring gull's beak." Animal Behavior, 77, p. 785-794.

2009b. "Tinbergen revisited: a replication and extension of experiments on the beak colour preferences of herring gull chicks." Animal Behavior, 77, p. 795802.

THE COLONIST. Nelson, New Zealand. Disponível em <https://paperspast.natlib.govt.nz〉. Acesso em 07/07/2017.

TILMAN, D.; MAY, R. M.; LEHMAN, C. L.; NOWAK, M. A. 1994. "Habitat destruction and the extinction debt"'. Nature, n. 371, p. 65-66

TINBERGEN, N. 1965. Animal Behavior. New York: Time-Life.

TIMMINS, R. J. et al. 2008. "Macaca mulatta." The IUCN Red List of Threatened Species. Disponível em <http://www.iucnredlist.org/details/12554/0 > . Acesso em 07/07/2017.

VALENTIM, M. A. 2013. "Extramundanidade e sobrenatureza." Natureza Humana, v. 15 (2), p. 48-93. Disponível em: $\langle$ http://revistas.dwwe.com.br/index.php/NH/article/view/31/16>. Acesso em 07/07/2017.

VAN DOOREN, T. "Spectral Crows in Hawai'i: Conservation and the Work of Inheritance." In ROSE, D. B.; van DOOREN, T.; CHRULEW, M. 2017. Extinction Studies. Stories of Time, Death, and Generations. New York: Columbia University Press. Edição Kindle.

VAN HOOF, J.A; LUKENAAR, B. 2015. "Captive chimpanzee takes down a drone: a toll use toward a flying object." Primates. Journal of Primatology, v. 56, n. 4, p. 289-292. 
VELLEND, M. et al. 2006. "Extinction debt of forest plants persists for more than a century following habitat fragmentation." Ecology, n. 87, p. 542-548.

VENDEMIATTI, L.A. 2003. Sobre a Natureza dos Deuses de Cícero. Dissertação de Mestrado. Unicamp. 141p.

VIVEIROS DE CASTRO, E. 2002. "Imanência do inimigo." In A inconstância da alma selvagem - e outros ensaios de antropologia. São Paulo: Cosac Naify, p. 267-294.

91-127.

2007. "Filiação intensiva e aliança demoníaca." Novos Estudos, n. 77, p.

2015. Metafísicas canibais. São Paulo: Cosac Naify/N-1 Edições.

2016. Os involuntários da pátria. Série Pandemia. São Paulo: N-1 Edições.

WARKENTIN, T. 2006. "Dis/integrating animals: ethical dimensions of the genetic engineering of animals for human consumption". AI \& Society, 20, p. 82102.

WHITEHEAD, A. N. 1978. Process and Reality. An Essay in Cosmology. New York: The Free Press.

1994. O conceito de natureza. Tradução de Julio B. Fischer. São Paulo: Martins Fontes.

WOOLF, V. 2006. Three Guineas. Annotated and with an Introductionby Jane Marcus. New York: Harcourt. Edição Kindle.

WOOTON, D. 2006. Bad Medicine. Doctors doing harm since Hippocrates. New York: Oxford University Press.

ZOURABICHVILI, F. 1997. “Qu'est-ce qu'un devenir, pour Gilles Deleuze?" Conférence prononcée à Horlieu (Lyon) le 27 mars 1997. Disponível em $<$ http://horlieu-editions.com/brochures/zourabichvili-qu-est-ce-qu-un-devenirpour-gilles-deleuze.pdf $>$. Acesso em 07/07/2017.

2005. "Deleuze e a questão da literalidade". Educação \& Sociedade. Campinas, v. 26, n. 93, p. 1309-1321, Set./Dez.

\section{Filmografia}

2001: Uma odisséia no espaço (2001: A Space Odyssey). 1968. Direção de Stanley Kubrick. Reino Unido/EUA: A Stanley Kubrick Production/MetroGoldwyn-Mayer, $161 \mathrm{~min}$.

A BELA e o monstro (The Monster and the Girl). 1941. Direção de Stuart Heisler. EUA: Paramount Pictures, 65 min. 
A FERA do mar (The Sea Beast). 1926. Direção de Millar Webb. EUA: Warner Brothers, $100 \mathrm{~min}$.

A ILHA das almas selvagens (The Island of Lost Souls).1932. Direção de Erle C. Kenton. EUA: Paramount Pictures, 71 min.

A MULHER fera (Captive Wild Woman). 1943. Direção de Edward Dmytryk. EUA, Universal Pictures, 61 min.

A MULHER gorila (The Jungle Captive). 1945. Direção de Harold Young. EUA: Universal Pictures, 63 min.

A NOITE dos mortos vivos (Night of the living dead). 1968. Direção de George A. Romero. EUA: The Walter Reade Organization/Continental Distributing, 96 $\min$.

A RAINHA das selvas (Jungle Woman). 1944. Direção de Reginald Le Borg. EUA: Universal Pictures, 61 min.

BANQUETE de zumbis (Dead Meat). 2004. Direção de Conor McMahon. Irlanda: Three Way Distributors, 80 min.

BEGINNING of The End. 1957. Direção de Bert I. Gordon. EUA: Republic Pictures, 76 min.

BLACKFISH. 2013. Direção de Gabriela Cowperthwaite. EUA: CNN Films/Manny O. Productions/Magnolia Pictures: 83 min.

CONTERRÂNEOS velhos de guerra. 1990. Direção de Vladimir Carvalho. Brasil, 175 min.

DAQUI a cem anos (Things to come) 1936. Direção de William Cameron Menzies. Reino Unido: London Film Productions/United Artists, 108 min.

DEVIL Monster. 1936. Direção de S. Edwin Graham. EUA: Louis Weiss Productions, 63 min.

DIAS passados. (Days Gone By). 2010. Direção de Frank Darabont. In WALKING Dead. EUA: AMC, $67 \mathrm{~min}$.

DILÚVIO (Deluge). 1933. Direção de Felix E. Feist. EUA: RKO Radio Pictures, 70 min.

ENTRANHAS. 2010. (Guts) Direção de Michelle MacLaren. In WALKING Dead. EUA: AMC, 45 min.

GHIDRAH, o monstro tricéfalo (San Daikaijū: Chikyū Saidai no Kessen). 1964. Direção de Ishiro Honda. Japão: Toho, 92 min.

GODZILLA (Gojira). 1954. Direção de Ishiro Honda. Japão: Toho, 96 min.

GUERRA dos planetas (This Island Earth). 1955. Direção de Joseph N. Newman e Jack Arnold. EUA: Universal Pictures, 86 min.

JURASSIC park - o Parque dos dinossauros (Jurassic Park). 1993. Direção de Steven Spielberg. EUA: Amblin Entertainment/Universal Pictures, 127 min.

KING Kong. 1933. Direção de Merien C. Cooper e Ernest B. Schoedsack. EUA: Radio Pictures, 104 min.

L'ABÉCÉDAIRE de Gilles Deleuze. 1996. Direção de Pierre-André Boutang e Michel Pamart. França: La Femis/Sodaperaga, 450 min. 
MONSTRO de um mundo perdido (Mighty Joe Young). 1949. Direção de Ernest B. Shoedsack. EUA: Argosy Pictures/RKO Radio Pictures, 93 min.

MONSTRO marinho (The Sea Bat). 1930. Direção de Lionel Barrymore e Wesley Ruggles. EUA: Metro-Goldwin-Mayer, 73 min.

O DIA dos mortos (Day of the dead). 1985. Direção de George A. Romero. EUA: Dead Films Inc./Laurel Entertainment Inc./Laurel-Day Inc./United Film Distribution Company, 100 min.

O ENIGMA de outro mundo (The Thing). 1982. Direção de John Carpenter. EUA: The Turman-Foster Company/Universal Pictures, 109 min.

O FALCÃO maltês (The Maltese Falcon). 1941. Direção de John Huston. EUA: Warner Brothers, 101 min.

O FIM do mundo (La fin du monde). 1931. Direção de Abel Gance. França: L'Écran d'Art: 105 min.

O HOTEL da fuzarca (The Cocoanuts). 1929. Direção de Robert Florey e Joseph Santley. Paramount Pictures: EUA, 93 min.

O MONSTRO do mar revolto (It Came from Beneath the Sea). 1955. Direção de Robert Gordon. EUA: Clover Productions/Columbia Pictures, 79 min.

O MUNDO em perigo (Them!...). 1954. Direção: Gordon Douglas. EUA: Warner Bros. Pictures, 94 min.

O PASSO do monstro (The Monster Walks). 1932. Direção de Frank R. Strayer. EUA: Mayfair Pictures Corporation/Astor Pictures/Commonwealth Pictures, 63 $\min$.

OS ASSASSINATOS da rua Morgue (Murders in the Rue Morgue). 1932. Direção de Robert Florey. EUA: Universal Pictures, 61 min.

OS ÚLTIMOS passos de um homem (Dead Man Walking). 1995. Direção de Tim Robbins. EUA: Polygram Film Entertainment/Working Title Films, 122 min.

PONGO, o gorila branco (White Pongo). 1945. Direção de Sam Newfield. EUA: Sigmund Neufeld Productions, 71 min.

QUARENTENA (Isolation). 2005. Direção de Billy O'Brien. Irlanda: Film Four/Irish Film Board et al, 95 min.

THE FAMILY of chimps (Chimps onder elkaar). 1984. Direção de Bert Haanstra. Holanda: Bert Haanstra Films/ Nederlands Instituut voor Beeld en Geluid, 55 min.

THE HOUND of the Baskervilles. 1921. Direção de Maurice Elvey. Reino Unido: Stoll Pictures, $61 \mathrm{~min}$.

VAMPIROS de almas (Invasion of The Body Snatchers). 1956. Direção de Don Siegel. EUA: Walter Warner Productions/Allied Artists Pictures, $80 \mathrm{~min}$.

VEIO do espaço (It Came From Outer Space). 1953. Direção de Jack Arnold. EUA: Universal Pictures, $81 \mathrm{~min}$.

VERDENS Undergang. 1916. Direção de August Blom. Dinamarca: Nordisk Film: $77 \mathrm{~min}$.

WHITE Death. 1936. Direção de Edwin G. Bowen. Austrália: Barrier Reef Films/British Empire Films/MGM, 81 min. 